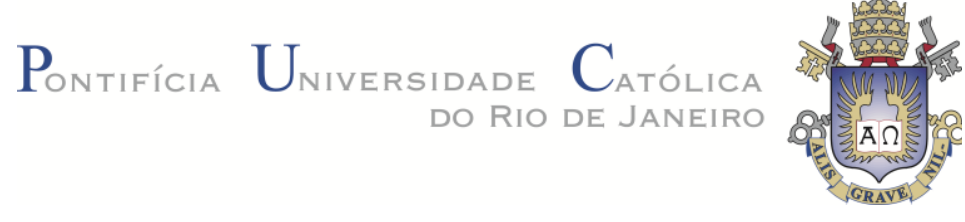

João Queiroz Krause

Micro e macromecânica de lâminas de bambu Dendrocalamus giganteus para aplicações estruturais

Tese de Doutorado

Tese apresentada como requisito parcial para obtenção do grau de Doutor pelo Programa de PósGraduação em Engenharia Civil do Departamento de Engenharia Civil da PUC-Rio.

Orientador: Prof. Khosrow Ghavami Coorientador: Prof. Flávio de Andrade Silva

Rio de Janeiro Dezembro de 2015 
João Queiroz Krause

\section{Micro e macromecânica de lâminas de bambu Dendrocalamus giganteus para aplicações estruturais}

Tese apresentada como requisito parcial para obtenção do grau de Doutor pelo Programa de Pós-Graduação em Engenharia Civil do Departamento de Engenharia Civil do Centro Técnico Científico da PUC-Rio. Aprovada pela Comissão Examinadora abaixo assinada.

Prof. Khosrow Ghavami Orientador Departamento de Engenharia Civil - PUC-Rio

Prof. Flávio de Andrade Silva Coorientador Departamento de Engenharia Civil - PUC-Rio

Profa. Elisa Dominguez Sotelino Departamento de Engenharia Civil - PUC-Rio

Prof. Daniel Carlos Taissum Cardoso Departamento de Engenharia Civil - PUC-Rio

Prof. Romildo Dias Toledo Filho COPPE UFRJ

Prof. Conrado de Souza Rodrigues CEFET MG

D.Sc. Otávio da Fonseca Martins Gomes CETEM

Prof. Márcio da Silveira Carvalho Coordenador Setorial do Centro Técnico Científico - PUC-Rio

Rio de Janeiro, 11 de dezembro de 2015 
Todos os direitos reservados. É proibida a reprodução total ou parcial do trabalho sem autorização da universidade, do autor e do orientador.

\section{João Queiroz Krause}

Graduado em Arquitetura e Urbanismo pela Universidade Federal Fluminense (2005), Mestre (2009) e atual doutorando em Engenharia Civil com ênfase em Estruturas pela PUC-Rio. Desenvolve pesquisas sobre sistemas estruturais utilizando materiais e tecnologias não convencionais, principalmente materiais compósitos de matriz polimérica reforçados com fibras naturais e bambu in natura ou conformado por laminação e colagem. Trabalha atualmente na Divisão de Eficiência Energética no Setor Privado da Eletrobras. Tem experiência nas áreas de: Artes, com ênfase em Restauro de Antiguidades e Obras de Arte; Arquitetura, com ênfase em Conforto Ambiental e Eficiência Energética e Engenharia Civil, com ênfase em Estruturas e Materiais.

Ficha Catalográfica

Krause, João Queiroz

Micro e macromecânica de lâminas de bambu Dendrocalamus giganteus para aplicações estruturais Micro and macromechanics of Dendrocalamus giganteus bamboo laminae for structural applications / João Queiroz Krause ; orientador: Khosrow Ghavami ; co-orientador: Flávio de Andrade Silva - 2015.

201 f. : il.(color.); $30 \mathrm{~cm}$

Tese (doutorado)-Pontifícia Universidade Católica do Rio de Janeiro, Departamento de Engenharia Civil, 2015.

Inclui bibliografia

1. Engenharia civil - Teses. 2. Bambu Dendrocalamus giganteus. 3. Compósitos estruturais laminados. 4. Microestrutura. 5. Propriedades mecânicas. I. Ghavami, Khosrow. II. Silva, Flávio de Andrade. III. Pontifícia Universidade Católica do Rio de Janeiro. Departamento de Engenharia Civil. IV. Título. 


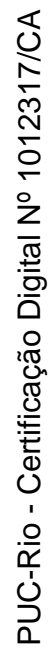

às mulheres da minha vida: mãe, esposa e filha. 


\section{Agradecimentos}

Aos Professores Khosrow Ghavami e Flávio de Andrade Silva, que aceitaram fazer parte deste trabalho;

Ao Professor Romildo Dias Toledo Filho e à COPPE/UFRJ, que propiciaram por meio do franqueamento de acesso e uso do LABEST (Laboratório de Estruturas), a execução de todo o processo experimental desta Tese;

À Fundação Centros de Referência em Tecnologias Inovadoras - CERTI em Santa Catarina pela realização e tratamento de dados das tomografias;

À Imperveg por ceder o adesivo utilizado para a confecção dos laminados;

Ao Professor Marcos Farina do CCS/UFRJ pelas ultramicrotomias, que permitiram a observação do bambu em microscopia ótica de transmissão;

Ao Professor Sidnei Paciornik, ao DSc. Haimon Alves e ao Laboratório de Processamento Digital de Imagens do Depertamento de Engenharia de Materiais da PUC-Rio pela realização das microtomografias;

Ao DSc. Otávio Gomes e ao CETEM por parte das micrografias óticas, pelas estereoscopias e, fundamentalmente, pelo processamento digital das imagens de microtomografia;

Aos membros da banca pelo tempo e empenho em avaliar este trabalho;

À Eletrobras, pelo apoio à elaboração desta Tese;

À CAPES e à PUC-Rio, pelos auxílios concedidos. 


\section{Resumo}

Krause, João Queiroz; Khosrow Ghavami (Orientador). Micro e macromecânica de lâminas de bambu Dendrocalamus giganteus para aplicações estruturais. Rio de Janeiro, 2016. 201p. Tese de Doutorado - Departamento de Engenharia Civil, Pontifícia Universidade Católica do Rio de Janeiro.

O bambu é um material compósito lignocelulósico natural, local, renovável e abundante, importante para o sequestro de carbono da atmosfera, caracterizado pela classificação funcional multidimensional e pela matriz consideravelmente porosa reforçada por fibras longas. Tais configurações proporcionam baixa densidade aliada a propriedades mecânicas adequadas à construção civil. Este trabalho propõe combinar aproveitamento adequado e alto desempenho, aplicando configurações diferenciadas a compósitos laminados, utilizando material proveniente de diferentes trechos da parede do colmo, de acordo com os requerimentos estruturais, de uma maneira viável para o desenvolvimento de formas complexas. Foram sistematizadas e propostas novas configurações para normas de ensaios de controle bem como procedimentos e ensaios específicos para a caracterização mecânica de lâminas, e para compósitos laminados de bambu. No intuito de quantificar e caracterizar a organização morfológica do bambu, principalmente relacionada à sua alta porosidade, foram conduzidas análises microestruturais diversas. Os dados foram correlacionados com as propriedades mecânicas obtidas experimentalmente de regiões similares. Desenvolveu-se ainda um método simplificado para estimar o teor total de vazios em lâminas baseado em ensaios de variação de umidade. Observou-se que a fração de vazios varia de acordo com uma classificação funcional e influencia, não somente na densidade do material, mas também em suas propriedades mecânicas. Os empacotamentos propostos para os laminados foram analisados em programa comercial de Elementos Finitos.

\section{Palavras-chave}

Bambu Dendrocalamus giganteus; compósitos estruturais laminados; microestrutura; propriedades mecânicas. 


\section{Abstract}

Krause, João Queiroz; Khosrow Ghavami (Advisor). Micro and macromechanics of Dendrocalamus giganteus bamboo laminae for structural applications. Rio de Janeiro, 2016. 201p. D.Sc. Thesis - Departamento de Engenharia Civil, Pontifícia Universidade Católica do Rio de Janeiro.

Bamboo is a natural, local, renewable and abundant lignocellulosic material, important to mitigate greenhouse gases emissions. It is characterized by the multidimensional functionally graded structure and for its long fiber reinforced porous matrix. Such configurations provide the combination of low density and high mechanical properties, which are compatible with the ones of usual construction materials. Laminated bamboo composites are currently produced aiming either high productivity and complex geometry with low performance, or simple geometry for structural purposes with a very low productivity. This work proposes a protocol to combine productivity, possibility of complex geometry and high performance, by applying laminae obtained from different parts of the culm wall, regarding to the radial axis, according to the structural requirements. New configurations for standard mechanical test methods were proposed for material's compliance checking and both for laminae and laminates characterization. In parallel, aiming to quantify and morphologically characterize, mainly the bamboo porosity variation, several microstructural analyzes have been used. The results were compared with the ones obtained on the experimental mechanical characterization protocol. A simplified method to quantify bamboo porosity based on humidity variation tests has been developed and validated by the comparison with digital image processing. It has been observed that bamboo's porous volume fraction is functionally graded and has influence on the material's density as long as on its mechanical properties. The proposed laminate configuratons were analyzed on a commercial Finite Element Method software.

\section{Keywords}

bamboo Dendrocalamus giganteus; structural laminate composites; microstructure; mechanical properties. 


\section{Sumário}

1 . Introdução 25

1.1. Contextualização histórica 26

1.2. Objetivos 28

1.2.1. Gerais 28

1.2.2. Específicos 28

1.3. Justificativas 28

1.3.1. Gerais 28

1.3.2. Específicas 29

1.4. Hipóteses e soluções 29

1.5. Estrutura resumida da Tese 30

2. Revisão Bibliográfica 32

2.1. Materiais compósitos 32

2.1.1. Laminados 33

2.2. Materiais biológicos 33

2.3. Vegetais 34

2.3.1. Blocos de construção básicos 35

2.4. Bambu 36

2.4.1. Composição química 36

2.4.2. Caracterização multidimensional 37

2.4.3. Propriedades mecânicas 39

2.5. Caracterização das lâminas 44

2.6. Laminados de bambu 45

3 . Materiais utilizados e métodos para a obtenção, preparo e produção das lâminas e laminados de bambu 50

3.1. Introdução $\quad 50$

3.1.1. Bambu 50

3.1.2. Lâminas

3.1.3. Adesivo 54 
4. Caracterização multidimensional dos materiais estudados 57

4.1. Introdução $\quad 57$

4.1.1. Caracterização morfológica 58

4.2. Caracterização mesoestrutural via tomografia computadorizada 65

4.3. Caracterização microestrutural via microscopia ótica de luz transmitida e refletida e microscopia eletrônica de varredura

68

4.4. Caracterização microestrutural quantitativa, por meio de microtomografias computadorizadas

4.5. Outras possibilidades para a determinação de frações volumétricas

4.5.1. Fibras 79

$\begin{array}{ll}\text { 4.5.2. Matriz } & 79\end{array}$

4.5.3. Vazios 82

4.6. Funções de variação de fibras, matriz e vazios 82

5. Ensaios mecânicos de controle 85

5.1. Introdução 85

5.2. Ensaios de tração simples: Comparação entre corpos-de-prova ISO 22157 e ASTM D3039 86

5.3. Ensaios de compressão 92

5.4. Ensaios de cisalhamento 95

$\begin{array}{ll}\text { 5.5. Resultados } & 97\end{array}$

5.5.1. Ensaios de tração 97

5.5.2. Ensaios de compressão 108

$\begin{array}{ll}\text { 5.5.3. Ensaios de cisalhamento } & 116\end{array}$

6 . Ensaios para a caracterização física e mecânica das lâminas 121

$\begin{array}{ll}\text { 6.1. Introdução } & 121\end{array}$

$\begin{array}{ll}\text { 6.2. Ensaios de variação de umidade } & 121\end{array}$

$\begin{array}{lc}\text { 6.2.1. Ensaio de Absorção } & 123\end{array}$

$\begin{array}{ll}\text { 6.2.2. Peso específico } & 124\end{array}$

$\begin{array}{lr}\text { 6.2.3. Estabilidade dimensional } & 125\end{array}$ 
6.3. Ensaios de tração longitudinal às fibras 125

6.4. Ensaios de compressão paralela às fibras 127

6.5. Ensaios de cisalhamento (compressão 45ํ) 128

6.6. Ensaios de flexão 3 pontos 130

6.7. Ensaios de cisalhamento do adesivo 132

6.8. Resultados 134

6.8.1. Ensaios de variação de umidade $\quad 134$

6.8.2. Ensaios de tração longitudinal às fibras 141

6.8.3. Ensaios de compressão paralela às fibras 149

6.8.4. Ensaios de cisalhamento (compressão 45ํ) 158

6.8.5. Ensaios de flexão 3 pontos 168

6.8.6. Ensaios de cisalhamento do adesivo 175

7 . Ensaios mecânicos de laminados 177

7.1. Ensaios de flexão 3 pontos de laminados unidirecionais

(variação de composição) 177

7.2. Resultados 178

8. Modelagem e Análise de Laminados via Elementos Finitos $\quad 184$

8.1. Modelo de viga 185

8.2. Modelo de placa 186

8.3. Modelo sólido 186

8.4. Modelo sólido (lâminas) 187

8.5. Resultados 188

9 . Conclusões, recomendações e sugestões para trabalhos futuros 192

10. Referências Bibliográficas 194 


\section{Lista de figuras}

Figura 1: Diagrama esquemático da estrutura de uma fibra de bambu

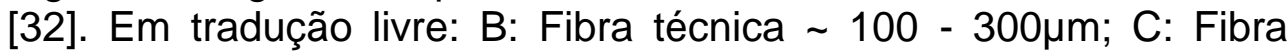

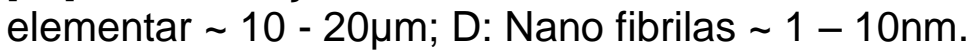

Figura 2: Gráficos tensão $x$ deformação a $(A)$ tração, $(B)$ Compressão e (C) flexão, obtidos por Verma et al. [72].

Figura 3: Graficos tensão x deformação à tração de laminados de bambu com 4 camadas [60].

Figura 4: a) Bambuzal manejado na PUC-Rio, desde 1979. b) Placas de marcação para acompanhamento da idade dos colmos.

Figura 5: a) Desenho original. b) Maquina em teste. c) Configuração final da divisora de lâminas de bambu - 1: regulagem de altura/posicionamento da lâmina divisora; 2: regulagem da pressão da mola; 3: lâmina divisora; 4: cilindro estabilizador; 5: mesa de entrada do material a ser laminado; 6: polia fixada ao cilindro trator; 7: motor bifásico $1 / 2 \mathrm{HP}$.

Figura 6: Processo de obtenção das lâminas de Dendrocalamus giganetus a partir do colmo completo: separação dos Internós e descarte dos diafragmas; cortes longitudinais para a obtenção das réguas; aparelhamento lateral das réguas; divisão das réguas e aparelhamento final das lâminas.

Figura 7: Gabarito de centralização para serra circular de bancada.

Figura 8: Prensa manual em ferro fundido e gabarito de prensagem em polipropileno.

Figura 9: a) Anel de região internodal de bambu para a obtenção de amostra a ser observada em MEV. b) Detalhe da seção do anel para a obtenção da amostra. c) Detalhe do corte do tamanho final para a amostra. d) Amostras extraídas das regiões apical, medial e basal após o coat de ouro.

Figura 10: Amostras de bambu da espécie Dendrocalamus giganteus, com (amarelo) e sem (vermelho), diafragma, das regiões basal (à esquerda), central e apical (à direita), para tomografia computadorizada.

Figura 11: Tomógrafo de aplicação industrial Zeiss, modelo Metrotom 1500 [81].

Figura 12: a) Amostra de bambu para microtomografia afixada à cabeça de um alfinete. b) da esquerda para a direita: fonte de raios 
$\mathrm{X}$; amostra de bambu; lente de 4x. c) fonte; amostra; detector e conjunto de lentes d) Microtomógrafo Zeiss Xradia 510 Versa [82].

Figura 13: Caixa de diálogo do software Zeiss Image Control com os parâmetros utilizados para a condução das tomografias nas amostras de bambu.

Figura 14: Vistas principais e cortes montados da tomografia da porção central de um colmo de Dendrocalamus giganteus em região internodal (16- internó) a saber: a) corte radial - plano xy; b) corte transversal - plano yz; c) corte radial - plano xz e d) perspectiva e referência de planos de corte.

Figura 15: Vistas principais e cortes montados da tomografia da porção central de um colmo de Dendrocalamus giganteus em região nodal (16ํinternó) a saber: a) corte radial - plano $x y$; b) corte transversal - plano yz; c) corte radial - plano xz e d) perspectiva e referência de planos de corte.

Figura 16: a) Gráfico relacionando frações volumétricas ao número do internó correspondente. b) Gráfico relacionando frações volumétricas ao número do nó correspondente.

Figura 17: MOLT, com magnificação de $5 X$, de corte transversal de Dendrocalamus giganteus obtido a partir de ultramicrotomia e comportamento do parênquima sob compressão transversal [83].

Figura 18: MOLT de corte transversal de Dendrocalamus giganteus com magnificação de 10X, detalhe de um dos feixes de fibras com magnificação de 50X, ilustração tridimensional de três fibras técnicas e da divisão das fibrilas em camadas e microestrutura de uma fibra técnica, exibindo as fibrilas [84].

Figura 19: MOLT, com magnificação de $5 \mathrm{X}$, de corte longitudinal de Dendrocalamus giganteus obtido a partir de ultramicrotomia e comportamento do parênquima sob compressão transversal.

Figura 20: MOLT de corte longitudinal de Dendrocalamus giganteus com magnificação de $10 \mathrm{X}$, detalhe de um dos feixes de fibras com magnificação de 50X.

Figura 21: a) Estereoscopia com lente de 1x, porção apical de Dendrocalamus giganteus. b) Estereoscopia com lente de $5 x$ da região mais interna da parede do colmo. c) Estereoscopia com lente de $5 x$ da regão medial interna da parede do colmo. d) Estereoscopia com lente de $5 x$ da região medial da parede do colmo. e) Detalhe em estereoscopia com lente de 10x, de um feixe de fibras na região medial da parede do colmo.

Figura 22: MOLR com aumento de $5 x$ obtida a partir da região apical, em porção central da parede em campo claro (a e c) e 
fluorescência (b e d).

Figura 23: MEVs da região medial da porção basal do bambu com magnificação de 30X obtidas a partir: a) da metade externa e b) da metade interna da parede do colmo e respectivos detalhes dos feixes de fibras com magnificação de 75X.

Figura 24: Cortes provenientes das 9 amostras de bambu Dendrocalamus giganteus submetidas a tomografia computadorizada, referentes às suas diferentes posições na altura do colmo e na espessura da sua parede e detalhe ampliado da resolução para visualização dos vazios do parênquima.

Figura 25: a) Seccionamento e segmentação (meso) por processamento digital de imagens e b) esquema de seccionamento sequencial de camadas transversais ao eixo radial do colmo.

Figura 26: Micrografia ótica de luz transmitida com fator de aumento de 10x em uma amostra de bambu Dendrocalamus giganteus obtida por ultramicrotomia em seção transversal.

Figura 27: Micrografia ótica de luz transmitida com fator de magnificação de 10x em uma amostra de bambu Dendrocalamus giganteus obtida por ultramicrotomia em seção longitudinal. Detalhe ressaltado com fator de magnificação de 20x.

Figura 28: Gráficos de variação das frações volumétricas de fibras, matriz, porosidade da matriz e vasos para: a) uma amostra da porção medial de um colmo de Dendrocalamus giganteus; b) uma amostra da porção apical de um colmo da mesma espécie. c) esquemas de corte, explicitando a distância aproximada entre o limite interno da parede do colmo e o eixo da lâmina proveniente de cada camada (abcissa dos gráficos), para amostras de porções basais, mediais e apicais do colmo, respectivamente representadas da esquerda para a direita.

Figura 29: LABEST - Máquina universal de ensaios eletromecânica Shimadzu AG-X $100 \mathrm{kN}$ e esquema geral dos ensaios

Figura 30: De baixo para cima: Segmentos de base (internós 6 e 7, nó 6), meio (internós 16 e 17, nó 16) e topo (internós 33 e 34, nó 33) de bambu utilizados para a confecção dos corpos-de-prova de tração simples - controle.

Figura 31: Corpo-de-prova de tração simples recomendado pela ISO 22157 [4].

Figura 32: a) Flexão na região da garra em corpo-de-prova de parede fina. b) Cisalhamento alinhado com a zona de estricção em corpo-de-prova de parede fina [86]. c) Flexão na região da garra em corpo-de-prova de parede grossa. d) Cisalhamento alinhado com a zona de estricção e deslizamento em corpo-de-prova de parede 
grossa.

Figura 33: Corpo-de-prova de tração simples baseado nas recomendações da norma ASTM D3039 [85].

Figura 34: Esquema de ensaio de tração simples e detalhe do posicionamento do clip gage: a) conforme a ISO 22157 e b) conforme a ASTM D3039.

Figura 35: Medidor de umidade para madeiras da marca Minipa, modelo MWD-14A.

Figura 36: a) foto de garra específica para a condução do ensaio ASTM D3410 [88]; b) esquema das partes componentes da garra e do encaixe do corpo-de-prova na mesma [89].

Figura 37: Corpo-de-prova de compressão adaptado a partir do recomendado pela Norma ASTM D3410 [87].

Figura 38: Esquema de ensaio à compressão simples, adaptado a partir do recomendado pela Norma ASTM D3410 [87].

Figura 39: Corpo-de-prova de cisalhamento longitudinal proposto por Ghavami et al., [90], modificado a partir da ISO 22157 [4] e detalhe da seção ensaiada.

Figura 40: Setup de ensaio de cisalhamento simples proposto por Ghavami, et al., [90], modificado a partir da ISO 22157 [4].

Figura 41: a) corpo-de-prova de tração ISO ensaiado, apresentando fissuras por cisalhamento; b) detalhe da fissura na zona de transferência alinhada com a zona de estricção; vista de topo do corpo-de-prova, evidenciando o deslizamento e a falha por cisalhamento; d) detalhe da fratura a cisalhamento alinhada com a zona de estricção, associado à abertura, porconta da curvatura natural do material; e) detalhe de esmagamento da parede interna na região de contato com a garra.

Figura 42: Modo de falha típico dos corpos-de-prova ASTM: ruptura a tração das fibras individualmente na porção externa da parede do colmo e em bloco na porção interna.

Figura 43: Gráficos tensão x deformação, ASTM (linhas preenchidas) e ISSO (pontilhadas), das regiões internodais (à esquerda) e nodais (à direita) em porções basais, mediais e apicais do colmo (de cima para baixo).

Figura 44: Gráficos tensão $x$ deformação, ASTM e ISO, representativos das regiões internodais (à esquerda) e nodais (à direita) comparativos entre porções basais, mediais e apicais do colmo. 
Figura 45: Relação entre a média das tensões de ruptura e: $(a, b)$ a posição no colmo e (c, d) a fração volumétrica de fibras dos corposde-prova ASTM e ISO de Dendrocalamus giganteus nas regiões (a, $c)$ internodais e $(b, d)$ nodais.

Figura 46: a) sentido de pressão da garra em corpos-de-prova ISO, de regiões basal, medial e apical (de baixo para cima) mostrando a variação na dimensão da largura do corpo-de-prova, correspondente à espessura da parede do colmo; b) sentido de pressão da garra em corpos-de-prova ASTM, de regiões basal, medial e apical (esquerda para a direita) mostrando a variação na dimensão da largura do corpo-de-prova, correspondente à espessura da parede do colmo.

Figura 47: Relação entre a média das deformações globais máximas e: $(a, b)$ a posição no colmo e (c, d) a fração volumétrica de fibras dos corpos-de-prova ASTM e ISO de Dendrocalamus giganteus nas regiões $(a, c)$ internodais $e(b, d)$ nodais.

Figura 48: Relação entre a média dos módulos de elasticidade e: (a, b) a posição no colmo e (c, d) a fração volumétrica de fibras dos corpos-de-prova ASTM e ISO de Dendrocalamus giganteus nas regiões $(a, c)$ internodais e $(b, d)$ nodais.

Figura 49: Curvas tensão x deformação dos ensaios à compressão para as porções: a) basal; b) medial e c) apical.

Figura 50: Curvas tensão x deformação representativas de corposde-prova ensaiados, provenientes de regiões intermodais das porções basal, medial e apical do colmo.

Figura 51: corpos-de-prova de compressão ensaiados. Visão global dos modos de falha típicos. a) região basal; b) região medial; c) região apical.

Figura 52: Separação por grupos com as principais características dos modos de ruptura associados aos ensaios de compressão.

Figura 53: Detalhe de alguns dos modos de falha observados em corpos-de-prova da porção basal. a) Flexão e formação de rótulas plásticas junto aos engastes (Grupo 1); b) Ruptura à compressão com flambagem local das fibras e esmagamento (Grupo 4).

Figura 54: Detalhe de alguns dos modos de falha observados em corpos-de-prova da porção medial. a) Flambagem global, esmagamento local e cisalhamento tipo 1 (Grupo 3); b) Cisalhamento tipo 1, flexo-compressão, e esmagamento junto ao engaste inferior (Grupo 5) .

Figura 55: Detalhe de alguns dos modos de falha observados em corpos-de-prova da porção apical. a) Flambagem local e esmagamento junto ao engaste inferior (Grupo 4); b) Flambagem global (Grupo 2); c) Esmagamento local, associado a cisalhamento 
tipo 1 (Grupo 5).

Figura 56: a) Tensão compressiva $\left(\sigma_{c}\right) \times$ Posição no colmo (pcolm); b) $\sigma_{\mathrm{c}} \times$ Fração volumétrica de fibras $\left(\mathrm{v}_{\mathrm{f}}\right)$; c) Módulo de elasticidade (E) $\times$ pcolm; d) $E \times v_{f}$; e) Deformação limite $(\varepsilon) \times$ pcolm; f) $\varepsilon \times v_{f}$.

Figura 57: Curvas tensão x deformação dos ensaios à cisalhamento para as porções basal (linha cheia), medial (tracejado curto) e apical (tracejado longo).

Figura 58: Curvas tensão $x$ deformação representativas de corposde-prova ensaiados, provenientes de regiões intermodais das porções basal, medial e apical do colmo.

Figura 59: Modo de falha característico de todos os corpos-de-prova de cisalhamento ensaiados. a) Parte externa da parede: superfície de cisalhamento limpa e alinhada com as extremidades dos entalhes; b) Superfície de cisalhamento bem marcada. Fissuras na camada interna (inner layer); c) Poucas fibras remanescentes na seção cisalhada.

Figura 60: Tensão cisalhante $\left(\tau_{\mathrm{s}}\right) \times$ Posição no colmo (pcolm); b) $\tau_{\mathrm{s}} \mathrm{x}$ Fração volumétrica de fibras $\left(\mathrm{v}_{\mathrm{f}}\right)$; c) Módulo de cisalhamento $(\mathrm{G}) \mathrm{x}$ pcolm; d) $G \times v_{f}$; e) Deformação limite $(\gamma) \times$ pcolm; f) $\gamma \times v_{f}$.

Figura 61: Corpo-de-prova para os ensaios de variação de umidade e variação dimensional.

Figura 62: Corpo-de-prova de tração simples baseado nas recomendações da norma ASTM D3039 [85], elaborado com seções circunferenciais de diferentes pontos da parede do colmo.

Figura 63: Corpo-de-prova de compressão adaptado a partir do recomendado pela Norma ASTM D3410 [87], elaborado com seções circunferenciais de diferentes pontos da parede do colmo; esquema de montagem dos enrijecedores e conjunto montado.

Figura 64: Setup de ensaio de compressão simples proposto para as lâminas.

Figura 65: Corpo-de-prova de cisalhamento, elaborado com seções circunferenciais de diferentes pontos da parede do colmo; esquema de montagem com os mordentes/estabilizadores e conjunto montado.

Figura 66: Setup de ensaio de cisalhamento simples.

Figura 67: Corpo-de-prova de flexão, elaborado com seções circunferenciais de diferentes pontos da parede do colmo.

Figura 68: Setup de ensaio de flexão 3 pontos. 
Figura 69: Corpo-de-prova para a verificação do cisalhamento na linha da colagem, baseado na norma ASTM D-3163 [91].

Figura 70: Setup de ensaio de cisalhamento na linha da colagem.

Figura 71: Ensaio de variação de densidade em diferentes processos de secagem e saturação ao longo do tempo: a) secagem a $50^{\circ} \mathrm{C}$ em estufa; b) saturação em água; c) secagem ao ar e d) secagem em estufa a $150^{\circ} \mathrm{C}$.

Figura 72: Detalhamento dos processos presentes na Figura 71: a) secagem a $50^{\circ} \mathrm{C}$ em estufa; b) saturação em água; c) secagem ao ar e d) secagem em estufa a $150^{\circ} \mathrm{C}$.

Figura 73: Gráficos de variação de frações volumétricas de fibras, matriz e vazios (estes obtidos por processamento digital de imagens e a partir da formulação proposta baseada nos resultados dos ensaios de variação de umidade) de: a) Porção basal do colmo (somente fração volumétrica de vazios pelo método proposto). Inclui referência de numeração da abcissa, que vale para os demais; b) Porção medial e c) Porção apical.

Figura 74: Curvas tensão deformação das diferentes camadas e porções do colmo, separadas por blocos de corpos-de-prova.

Figura 75: Gráficos tensão x deformação de curvas representativas de corpos-de-prova provenientes dos diferentes pontos das paredes das porções de colmo: a) basal; b) medial e c) apical.

Figura 76: llustração dos modos de ruptura observados nos ensaios à tração de lâminas procedentes de diferentes posições da parede e porções do colmo de bambu da espécie Dendrocalamus giganteus.

Figura 77: Modos de falha dos corpos-de-prova de tração. Cada porção do colmo está dividida em subconjuntos. Cada bloco numerado (CP) provem de uma mesma régua, dividida em sua espessura. As camadas mais externas estão à esquerda de cada bloco, variando gradualmente até as mais internas à direita.

Figura 78: Relação entre a fração volumétrica de fibras e: a) tensão na região medial; b) deformação na região medial; c) módulo de elasticidade na região medial; d) tensão na região apical; e) deformação na região apical e f) módulo de elasticidade na região apical.

Figura 79: Relação entre a fração volumétrica de matriz e: a) tensão na região medial; b) deformação na região medial; c) módulo de elasticidade na região medial; d) tensão na região apical; e) deformação na região apical e f) módulo de elasticidade na região apical.

Figura 80: Relação entre a fração volumétrica de vazios obtida por 
PDI e pelo método proposto e: a) tensão na região basal; b) deformação na região basal; c) módulo de elasticidade na região basal; d) tensão na região medial; e) deformação na região medial; f) módulo de elasticidade na região medial; g) tensão na região apical; h) deformação na região apical e i) módulo de elasticidade na região apical.

Figura 81: Curvas tensão deformação das diferentes camadas e porções do colmo, separadas por blocos de corpos-de-prova.

Figura 82: Gráficos tensão x deformação de curvas representativas de corpos-de-prova provenientes dos diferentes pontos das paredes das porções de colmo: a) basal; b) medial e c) apical.

Figura 83: llustração dos modos de ruptura observados nos ensaios à tração de lâminas procedentes de diferentes posições da parede $\mathrm{e}$ porções do colmo de bambu da espécie Dendrocalamus giganteus.

Figura 84: Modos de falha dos corpos-de-prova de compressão. Cada bloco numerado $(\mathrm{CP})$ provem de uma mesma régua da região basal, dividida em sua espessura.

Figura 85: Modos de falha dos corpos-de-prova de compressão. Cada bloco numerado $(\mathrm{CP})$ provem de uma mesma régua da região central, dividida em sua espessura.

Figura 86: Modos de falha dos corpos-de-prova de compressão. Cada bloco numerado $(\mathrm{CP})$ provem de uma mesma régua da região apical, dividida em sua espessura.

Figura 87: Relação entre a fração volumétrica de fibras e: a) tensão na região central; b) deformação na região central; c) módulo de elasticidade na região central; d) tensão na região apical; e) deformação na região apical e f) módulo de elasticidade na região apical.

Figura 88: Relação entre a fração volumétrica de matriz e: a) tensão na região central; b) deformação na região central; c) módulo de elasticidade na região central; d) tensão na região apical; e) deformação na região apical e f) módulo de elasticidade na região apical.

Figura 89: Relação entre a fração volumétrica de vazios obtida por PDI e pelo método proposto e: a) tensão na região basal; b) deformação na região basal; c) módulo de elasticidade na região basal; d) tensão na região medial; e) deformação na região medial; f) módulo de elasticidade na região medial; g) tensão na região apical; h) deformação na região apical e i) módulo de elasticidade na região apical.

Figura 90: Curvas tensão deformação das diferentes camadas e 
porções do colmo, separadas por blocos de corpos-de-prova.

Figura 91: Gráficos tensão x deformação de curvas representativas de corpos-de-prova provenientes dos diferentes pontos das paredes das porções de colmo: a) basal; b) medial e c) apical.

Figura 92: Modos de falha dos corpos-de-prova de cisalhamento. Cada bloco numerado $(\mathrm{CP})$ provem de uma mesma régua da região basal, dividida em sua espessura.

Figura 93: Modos de falha dos corpos-de-prova de cisalhamento. Cada bloco numerado $(\mathrm{CP})$ provem de uma mesma régua da região central, dividida em sua espessura.

Figura 94: Modos de falha dos corpos-de-prova de cisalhamento. Cada bloco numerado $(\mathrm{CP})$ provem de uma mesma régua da região apical, dividida em sua espessura.

Figura 95: Relação entre a fração volumétrica de fibras e: a) tensão na região central; b) deformação na região central; c) módulo de elasticidade na região central; d) tensão na região apical; e) deformação na região apical e f) módulo de elasticidade na região apical.

Figura 96: Relação entre a fração volumétrica de matriz e: a) tensão na região central; b) deformação na região central; c) módulo de elasticidade na região central; d) tensão na região apical; e) deformação na região apical e f) módulo de elasticidade na região apical.

Figura 97: Relação entre a fração volumétrica de vazios obtida por PDI e pelo método proposto e: a) tensão na região basal; b) deformação na região basal; c) módulo de elasticidade na região basal; d) tensão na região medial; e) deformação na região medial; f) módulo de elasticidade na região medial; g) tensão na região apical; h) deformação na região apical e i) módulo de elasticidade na região apical.

Figura 98: Curvas carga $x$ deslocamento das diferentes camadas e porções do colmo, separadas por blocos de corpos-de-prova.

Figura 99: Gráficos carga x deslocamento de curvas representativas de corpos-de-prova provenientes dos diferentes pontos das paredes das porções de colmo: a) basal; b) medial e c) apical.

Figura 100: Modos de ruptura característicos dos ensaios a flexão 3 pontos das lâminas provenientes dos diferentes pontos das paredes das porções de colmo. a1) ruptura dominada pela seção comprimida - vista lateral; a2) vista superior; b1) falha dominada pela seção tracionada - vista lateral; b2) vista inferior; c) falha equilibrada entre as seções tracionada e comprimida; d) falha por cisalhamento 
interlaminar associado à tração.

Figura 101: Relação entre a fração volumétrica de fibras e: a) força máxima na região central; b) flecha na região central; c) módulo de elasticidade na região central; d) força máxima na região apical; e) deslocamento na região apical e f) módulo de elasticidade na região apical.

Figura 102: Relação entre a fração volumétrica de matriz e: a) força máxima na região central; b) flecha na região central; c) módulo de elasticidade na região central; d) força máxima na região apical; e) flecha na região apical e f) módulo de elasticidade na região apical.

Figura 103: Relação entre a fração volumétrica de vazios obtida por PDI e pelo método proposto e: a) força máxima na região basal; b) flecha na região basal; c) módulo de elasticidade na região basal; d) força máxima na região medial; e) flecha na região medial; f) módulo de elasticidade na região medial; g) força máxima na região apical; h) flecha na região apical e i) módulo de elasticidade na região apical.

Figura 104: curvas tensão $\mathrm{x}$ deformação dos ensaios de cisalhamento do adesivo poliuretano utilizado para os laminados.

Figura 105: regiões de falha dos corpos-de-prova.

Figura 106: Corpo-de-prova de flexão, elaborado com composições de seções circunferenciais de diferentes pontos da parede do colmo.

Figura 107: Setup de ensaio de flexão 3 pontos em laminado unidirecional de 5 camadas.

Figura 108: Gráficos carga x deslocamento dos corpos-de-prova com diferentes empacotamentos: a) leve: composto por lâminas internas da porção central do colmo; b) médio: composto por lâminas provenientes da camada medial da porção central do bambu; c) resistente: proveniente de camadas externas da mesma porção e d) balanceado, que alia camadas externas nas faces mais distantes da linha neutra nos laminados e camadas internas no centro do corpode-prova.

Figura 109: Gráficos carga x deslocamento de curvas representativas de corpos-de-prova elaborados com os diferentes empacotamentos de laminados propostos.

Figura 110: Corpos-de-prova ensaiados das configurações: a) resistente; b) médio; c) leve e d) balanceado.

Figura 111: Detalhes dos modos de ruptura dos corpos-de-prova ensaiados.

Figura 112: imagem do modelo de viga elaborado: a) evidenciando a 
discretização e a posição dos apoios; b) Exibindo sua configuração deformada após a aplicação de esforço no centro do vão; c) diagrama de momento fletor associado ao modelo.

Figura 113: modelo de placa elaborado: a) configuração deformada; b) discretização dos elementos utilizados; c) e d) tomadas superior e inferior do modelo com sua distribuição de tensões aplicada.

Figura 114: modelo sólido: a) discretização dos elementos utilizados; b) configuração deformada e c) tomada superior do modelo com distribuição de tensões aplicada.

Figura 115: modelo sólido elaborado com as propriedades das lâminas isoladas: a) discretização dos elementos utilizados; b) configuração deformada e c) tomada superior do modelo com distribuição de tensões aplicada.

Figura 116: comparação entre as envoltórias de esforços simplificadas obtidas por simulação e os deslocamentos obtidos experimentalmente, para as diversas configurações de laminados propostas. 


\section{Lista de tabelas}

Tabela 1: Comparativo entre propriedades mecânicas à tração de bambus de diversas espécies, de acordo com sua posição no colmo/parede e região (nodal ou internodal).

Tabela 2: Propriedades mecânicas à tração de lâminas de bambu Dendrocalamus strictus para uso em laminados estruturais (adaptado de Verma, et al., 2013)

Tabela 3: Empacotamentos de laminados: a) Resistente; b) Médio; c) Leve; d) Balanceado.

Tabela 4: Configuração utilizada para a condução das tomografias. Em destaque os parâmetros editáveis.

Tabela 5: Volumes e frações volumétricas mesoestruturais de vazios matriz e fibras de regiões internodais $(\mathrm{IN})$ e nodais $(\mathrm{N})$, provenientes de base (B), meio (M) e topo (T) de um colmo de Bambu Dendrocalamus giganteus.

Tabela 6: Parâmetros de correlação entre micra, pixels e voxels e frações volumétricas dos constituintes obtidas em porcentagem.

Tabela 7: Funções de variação radial de frações volumétricas dos constituintes e vazios de um colmo de bambu Dendrocalamus giganteus.

Tabela 8: Lista de corpos-de-prova ASTM e ISO de regiões internodais com informações gerais sobre as condições de ensaio e registros de tensão máxima, deslocamento global máximo e modulo de elasticidade.

Tabela 9: Lista de corpos-de-prova ASTM e ISO de regiões nodais com informações análogas às apresentadas na Tabela 8.

Tabela 10: Tensões, deformações e módulos de elasticidade médios e seus respectivos desvios padrão.

Tabela 11: Lista de corpos-de-prova de regiões internodais com informações gerais sobre os modos de ruptura e registros de tensão máxima, deformação global máxima equivalente e modulo de elasticidade.

Tabela 12: Valores médios e desvios padrão associados das propriedades mecânicas à compressão obtidas experimentalmente para as porções basal, medial e apical de regiões intermodais de bambu da espécie Dendrocalamus giganteus. 
Tabela 13: Lista de corpos-de-prova de cisalhamento com informações gerais sobre as condições de ensaio e registros de tensão máxima, deslocamento global máximo e modulo de elasticidade.

Tabela 14: Valores médios e desvios padrão associados das propriedades mecânicas à cisalhamento obtidas experimentalmente para as porções basal, medial e apical de regiões intermodais de bambu da espécie Dendrocalamus giganteus.

Tabela 15: Dimensões, volume, massa e densidade das amostras de bambu das diferentes camadas da parede e porções do colmo, sob diferentes condições de umidade.

Tabela 16: Quadro com as propriedades físicas medidas e calculadas para amostras das diferentes camadas da parede e porções do colmo de Dendrocalamus giganteus.

Tabela 17: Resultados dos ensaios de estabilidade dimensional em relação ao volume de cada amostra e às suas dimensões.

Tabela 18: Lista de corpos-de-prova das regiões basal, medial e apical, provenientes das diferentes camadas da parede do colmo, com informações gerais imediatamente anteriores ao ensaio, descrição sumarizada dos modos de ruptura e registros de tensão máxima, deformação global máxima equivalente e modulo de elasticidade obtidos nos ensaios à tração.

Tabela 19: Médias e desvios padrão das densidades, tensões máximas, deformações máximas equivalentes (computadas quando da tensão máxima) e módulos de elasticidade, obtidas pelos corposde-prova ensaiados à tração, bem como suas propriedades específicas.

Tabela 20: Lista de corpos-de-prova das regiões basal, medial e apical, provenientes das diferentes camadas da parede do colmo, descrição sumarizada dos modos de ruptura e registros de tensão máxima, deformação global máxima equivalente e modulo de elasticidade obtidos nos ensaios à compressão.

Tabela 21: Médias e desvios padrão das tensões máximas, deformações máximas equivalentes (computadas quando da tensão máxima) e módulos de elasticidade, obtidas pelos corpos-de-prova ensaiados à compressão, bem como suas propriedades específicas.

Tabela 22: Lista de corpos-de-prova das regiões basal, medial e apical, provenientes das diferentes camadas da parede do colmo, com informações gerais imediatamente anteriores ao ensaio, descrição sumarizada dos modos de ruptura e registros de tensão máxima, deformação global máxima equivalente e modulo de elasticidade obtidos nos ensaios ao cisalhamento. 
Tabela 23: Médias e desvios padrão das tensões máximas, deformações máximas equivalentes (computadas quando da tensão máxima) e módulos de elasticidade, obtidas pelos corpos-de-prova ensaiados ao cisalhamento, bem como suas propriedades específicas.

Tabela 24: Quadro com os corpos-de-prova, algumas de suas propriedades físicas e mecânicas e uma descrição dos seus modos de ruptura.

Tabela 25: Sumário das propriedades físicas e mecânicas médias e seus respectivos desvios padrão, para as diferentes camadas e porções de colmo, bem como suas propriedades específicas.

Tabela 26: Resultados dos ensaios de cisalhamento na linha da colagem, incluindo as médias e desvios padrão.

Tabela 27: Quadro com os corpos-de-prova, algumas de suas propriedades físicas e mecânicas e uma descrição dos seus modos de ruptura.

Tabela 28: Sumário das propriedades físicas e mecânicas médias e seus respectivos desvios padrão, para os diferentes empacotamentos de laminados, bem como suas propriedades específicas.

Tabela 29: Pesos específicos e módulos de elasticidade médios utilizados como parâmetro nos modelos em MEF.

Tabela 30: Parâmetros utilizados para as lâminas do modelo, agrupados de acordo com a configuração do laminado.

Tabela 31: Quadro resumo dos modelos, seus parâmetros, condições de contorno e os deslocamentos obtidos para cada caso. 


\section{1. Introdução}

Duas possibilidades gerais de pesquisa caminham em paralelo no que diz respeito ao estudo dos materiais e tecnologias não-convencionais, dentre os quais o bambu:

- a primeira está relacionada ao trabalho com os materiais de uma maneira artesanal, otimizando o aproveitamento de suas propriedades, com o mínimo processamento possível. Este pressuposto implica em desenvolver pessoas para o trabalho específico por meio de metodologias simplificadas, para o desenvolvimento de estruturas simples ou complexas. Inevitavelmente a caracterização do material em sua configuração natural faz-se nesse caso necessária para o dimensionamento e para o desenvolvimento de metodologias específicas para a sua aplicação;

- a segunda está relacionada ao processamento dos materiais, de modo a otimizar suas propriedades e aplicabilidades, de modo a facilitar o seu uso, sem a necessidade de formação de mão-de-obra específica e procurando manter um trade off favorável em relação ao desenvolvimento sustentável. Nesse caso, a caracterização do material processado faz-se necessária para engenheirá-los adequadamente, permitindo a constituição de compósitos com as propriedades e configurações desejadas.

Ambos os enfoques são válidos e possuem seus respectivos nichos de mercado, não configurando competitividade, mas sim complementaridade.

Este trabalho parte de um enfoque relacionado ao processamento do material por meio da caracterização de lâminas e do desenvolvimento de compósitos laminados de bambu.

O bambu é um material funcionalmente graduado, que apresenta variação da fração volumétrica de fibras e vazios ao longo da espessura do colmo. Esta variação incorre em comportamentos e propriedades diferenciadas, dependendo do ponto de onde se extraem lâminas para a confecção de laminados 
1.

estruturais. O estudo da variação da fração volumétrica de fibras já é bem conhecido, no entanto a variação da fração de vazios ainda não recebeu atenção devida. Cabe ressaltar que o bambu se destaca como material de construção por suas propriedades específicas, isto é, pela relação entre as suas propriedades e sua densidade. A baixa densidade relaciona-se diretamente à considerável proporção de vazios do material e suas propriedades mecânicas devem-se à organização e morfologia dos seus constituintes.

De uma maneira geral, as pesquisas acerca de compósitos laminados de bambu utilizam lâminas extraídas da porção mais externa do colmo, que possuem maior fração volumétrica de fibras, entretanto, outras configurações podem ser geradas, de modo a reduzir o desperdício de material e, consequentemente incrementando a produtividade de laminados, gerando materiais mais resistentes, mais leves ou balanceados (núcleo leve e camadas externas resistentes) de acordo com os requerimentos estruturais de projeto.

A tecnologia de compósitos laminados permite ainda o desenvolvimento de formas complexas sem abdicar das propriedades mecânicas, possibilitando a produção de formas curvas e/ou com solicitações em diversas direções por meio da variação da espessura e orientação de camadas.

\subsection{Contextualização histórica}

Durante milênios materiais e técnicas construtivas foram desenvolvidos e aplicados de maneira vernácula na construção civil em todo o mundo, mas após a Revolução Industrial dois materiais em especial desenvolvem progressivamente uma hegemonia no que diz respeito à construção de estruturas: o aço e o concreto. A partir do início do séc. $X X$ estes materiais começam a ser utilizados em larga escala. A necessidade de se parametrizar o uso destes materiais exigiu a elaboração de cartilhas de utilização, que viriam a ser denominadas normas técnicas. Posteriormente as normas se tornaram fator preponderante para a construção civil. Dessa maneira, materiais e técnicas milenares, então correntes, tiveram seu uso preterido, em favor daqueles cujos parâmetros de aplicação já se encontravam estabelecidos.

A Revolução Industrial proporcionou melhorias à humanidade e desvantagens à natureza, como a poluição desmedida do planeta e o consumo indiscriminado de recursos naturais. Após a Segunda Guerra Mundial a reconstrução da Europa demandou um consumo alto e frequente de materiais de 
1.

construção industriais, de maneira que na década de 1960 os danos ao meio ambiente se faziam perceptíveis. Desde então se procura difundir a consciência da avaliação de impacto ambiental. Na década de 1980 foi, neste ínterim, desenvolvido o conceito de sustentabilidade [1]. A ciência da sustentabilidade estuda as causas, caminhos e impactos de problemas de desenvolvimento complexo resultantes da interação entre forças naturais e sociais [2]. A degradação crescente dos recursos naturais não renováveis, como petróleo, minérios e fundamentalmente água potável, promove um panorama que demanda soluções para aplicação imediata, que não somente atendam à necessidade de reprodutibilidade renovável, como também, alternativas não poluentes e de baixo consumo energético. Na sociedade atual a demanda do potencial de comercialização e a viabilidade econômica são essenciais, não só quanto ao investimento a ser realizado, como também ao retorno financeiro que estes produtos deverão gerar em quanto tempo. O desenvolvimento técnicocientífico é, portanto, fundamental para a obtenção de materiais condizentes com a resistência, durabilidade, sustentabilidade, reprodutibilidade, acessibilidade e potencial de comercialização, exigidos pela sociedade.

As ciências ligadas à construção civil e ao desenvolvimento de materiais têm, neste contexto, responsabilidade, tanto no que tange à teorização, conceituação, desenvolvimento de soluções projetuais e conscientização (arquitetura e engenharia civil), quanto no que diz respeito à parametrização, cálculo e desenvolvimento de materiais e tecnologias (engenharias civil e de materiais).

É necessário desonerar a natureza do custo ambiental provocado pela indústria em geral. Para tanto, há que se encontrar meios de produção mais limpos para os materiais de construção convencionais e evitar o seu uso indiscriminado, limitando-o às situações em que se fizerem realmente necessários como a construção de grandes pontes, edifícios altos ou outras grandes obras de engenharia. Outras situações devem acolher materiais não convencionais novos ou antigos em desuso, renováveis e de baixo custo energético, favorecendo a construção vernácula adaptada às realidades climáticas, técnicas e econômicas locais ou a associação profícua, e inerente aos compósitos, entre materiais convencionais e não convencionais. É necessário ainda proceder à análise do ciclo de vida desses materiais, de modo a balancear a sua produção e destinar adequadamente os seus resíduos. 
1.

\subsection{Objetivos}

\subsubsection{Gerais}

Dando continuidade à linha de pesquisa, já tradicional, da PUC-Rio de Materiais e Tecnologias Não-convencionais objetiva-se disseminar o uso de materiais de construção com baixo impacto ambiental, notadamente bambu e derivados.

\subsubsection{Específicos}

Este trabalho pretende sistematizar procedimentos e ensaios para a caracterização de lâminas e compósitos laminados de bambu, bem como propor possibilidades de melhorar configurações de normas de ensaios de controle correntes. Em paralelo à caracterização mecânica, pretende-se proceder a análises microestruturais com técnicas diversas de modo a caracterizar a morfologia do material e quantificar as frações volumétricas de fibras, matriz e vazios, por meio de processamento digital de imagens, correlacionando os dados comas propriedades mecânicas do bambu. $\mathrm{O}$ trabalho visa ainda propor empacotamentos para os compósitos de tal forma que o desperdício de material seja minimizado em aplicações estruturais do bambu, mesmo quando da necessidade de conformação de formas complexas.

$O$ resultado final tende tanto ao atendimento à pesquisa fundamental, no que diz respeito à constituição de normas técnicas e sua fundamentação teóricoexperimental, como no atendimento à pesquisa de ponta gerando produtos a serem enquadrados no aspecto de inovação.

\subsection{Justificativas}

\subsubsection{Gerais}

O bambu foi escolhido como matéria-prima por ser um material dotado de propriedades mecânicas e características morfológicas interessantes para o uso em engenharia, não-convencional, local, renovável e abundante, importante para o sequestro de carbono da atmosfera, absorvendo (dependendo da espécie) até 52,3 t/ha por ano [3], além de estar sendo estudado há mais de trinta anos pelo Grupo de Materiais não-convencionais da PUC-Rio. Desta maneira estão disponibilizadas informações científicas sobre suas propriedades físicas e 
1.

mecânicas, seu tratamento, poda, armazenamento, suas patologias e sistemas construtivos que o empregam.

O bambu é um material compósito lignocelulósico natural de fibras longas funcionalmente graduado macro, meso e microdimensionalmente, cujas propriedades físicas e mecânicas propiciam o uso na construção civil, tanto em seu formato natural, como processado industrialmente para uso em materiais compósitos laminados ou extrudados de fibras longas ou curtas. Por esta versatilidade possibilita a confecção reprodutível de elementos estruturais complexos.

\subsubsection{Específicas}

A maioria dos compósitos laminados de bambu da atualidade são confeccionados visando máximo aproveitamento para possibilitar a constituição de formas complexas, preterindo o desempenho ou gerando formas simples para uso estrutural com um índice de desperdício muito elevado. Há que se gerar um protocolo para combinar um aproveitamento adequado e alto desempenho deste material, aplicando configurações diferenciadas de acordo com os requerimentos estruturais, de uma maneira viável para o desenvolvimento de formas complexas.

\subsection{Hipóteses e soluções}

H1- A caracterização de bambu para uso em laminados requer um procedimento de ensaios mecânicos específicos, utilizando o material processado, que não são atendidos pela Norma corrente [4].

S1- Adaptar procedimentos de ensaios derivados de normas para materiais compósitos laminados com fibras longas, utilizando bambu processado extraído de diferentes regiões do colmo em relação à altura e ao eixo radial. Proceder a comparações com ensaios mecânicos correntes, quando aplicável.

H2- A porosidade (fração volumétrica de vazios) do bambu e a sua morfologia são fatores fundamentais para as suas propriedades específicas. Os vazios são, tal como as fibras, distribuídos de acordo com uma graduação funcional. Entretanto, enquanto as fibras aumentam sua concentração na direção radial no sentido do córtex, a porosidade aumenta no sentido oposto, fundamentalmente na fase aglutinante (matriz). 
1.

S2- Realizar procedimentos de microscopia, tomografia e processamento digital de imagens para caracterizar morfologicamente o material, determinar a fração volumétrica de vazios e sua distribuição na parede do colmo e correlacionar os dados obtidos com a variação de densidade e com as propriedades mecânicas obtidas experimentalmente.

H3- É possível engenheirar laminados de bambu sob diferentes enfoques para atender a demandas específicas relativas a resistência e/ou à densidade, inclusive com formas e requerimentos complexos.

S3- Realizar ensaios mecânicos à flexão com diferentes empacotamentos e frações volumétricas de fibras e vazios de laminados de bambu. Realizar modelagem em elementos finitos destes empacotamentos. Realizar modelagem em elementos finitos considerando os diferentes empacotamentos com forma e demandas complexas.

\subsection{Estrutura resumida da Tese}

A primeira parte do documento, correspondente ao Capítulo 2, trata-se de uma revisão da literatura com uma estrutura lógica para a caracterização morfológica, química e mecânica de lâminas e laminados estruturais de bambu.

A segunda parte trata-se do Capítulo 3 e descreve de uma maneira geral os materiais, processos e equipamentos, alguns dos quais desenvolvidos para este trabalho, usados para a elaboração de corpos-de-prova, análises microestruturais e realização dos ensaios mecânicos.

A terceira parte refere-se ao Capítulo 4 e diz respeito à caracterização multidimensional de lâminas de bambu, através de diversas técnicas de microscopia e tomografia, e processamento digital de imagens, promovendo uma análise da morfologia do bambu e estudando quantitativamente a variação de fibras, vazios e matriz ao longo da parede do colmo e procedendo à regra das misturas a partir dos resultados obtidos em diferentes escalas de ampliação.

A quarta parte diz respeito ao procedimento de ensaios mecânicos e à análise comparativa dos seus resultados considerando os dados quantitativos obtidos no Capítulo 4, dividindo-se em 3 partes: Controle, que constitui o Capítulo 5; Caracterização das lâminas, Capítulo 6; Laminados, Capítulo 7.

A quinta parte corresponde ao Capítulo 8 e refere-se à modelagem dos laminados em programa comercial de análise estrutural baseado no Método dos Elementos Finitos, adotando diferentes configurações, de acordo com as ensaiadas no Capítulo 7, bem como estratégias de modelamento distintas, 
1.

buscando reproduzir adequadamente o fenômeno físico da maneira mais simplificada possível.

A sexta parte diz respeito às conclusões gerais, sugestões e recomendações para trabalhos futuros, e está consolidada no Capítulo 9.

Seguem-se, finalmente, as referências bibliográficas, finalizando o documento. 


\section{2. \\ Revisão Bibliográfica}

\subsection{Materiais compósitos}

São materiais que possuem como característica básica a combinação de duas ou mais fases distintas, dentre as quais há notadamente uma aglutinante, denominada matriz e uma de reforço [5] que, trabalhando em conjunto, possuem características distintas das dos seus constituintes isolados [6]. Estas propriedades frequentemente atendem a um propósito preestabelecido e são obtidas através do controle das frações volumétricas e da geometria de empacotamento dos constituintes do compósito.

Materiais compósitos são aqueles formados pela associação de dois ou mais materiais distintos com o objetivo principal de se obter características predeterminadas, não encontradas nos seus constituintes isoladamente [6].

Segundo Jones [7], existem três tipos mais comumente usados de materiais compósitos:

1. Os fibrosos, que são constituídos de fibras incorporadas a uma matriz;

2. Os laminados, formados por várias lâminas coladas com dois ou mais materiais;

3. Os particulados, que são os compostos por partículas associadas a uma matriz.

Os compósitos podem surgir de combinações entre metais, cerâmicas e polímeros. As possíveis combinações são condicionadas às condições de processamento e às prováveis incompatibilidades entre os componentes. Compósitos para aplicações estruturais geralmente utilizam fibras, sintéticas ou naturais, como agentes de reforço. As fibras podem ser contínuas ou descontínuas, alinhadas ou com distribuição aleatória, podendo ser obtidas em uma variedade de formas, como mantas e preformas têxteis de diferentes arquiteturas. Como componente matricial, os polímeros são os materiais mais utilizados devido à sua leveza e fácil moldagem. Em relação ao peso, os materiais compósitos poliméricos apresentam propriedades mecânicas específicas que podem exceder consideravelmente às dos metais [8]. 
2.

\subsubsection{Laminados}

Materiais compósitos laminados são aqueles estruturados pela associação de lâminas, pré-obtidas, compósitas ou não, unidas entre si por um agente adesivo, de modo que trabalhem conjuntamente para distribuir os esforços a que são submetidos. Usualmente são materiais formados por lâminas compósitas reforçadas por fibras longas, combinadas em quantidade e orientações diversas, de acordo com as exigências da função a que se destina e suas condições de contorno [6]. Em aplicações de alto desempenho, não raro incluem lâminas de materiais isotrópicos de modo a aumentar a rigidez nas camadas externas e/ou diminuir os efeitos de cisalhamento interlaminar em peças submetidas à flexão, fundamentalmente quando há mudança de direção do reforço entre as camadas.

Por conta da possibilidade de orientar a direção de reforço de acordo com a demanda, os laminados oferecem possibilidades estruturais interessantes, notadamente para placas. Além disso, por serem conformados (geralmente) a partir de lâminas finas permitem a conformação de formas complexas (cascas).

Refere-se atualmente à Teoria Clássica de Laminados à evolução de trabalhos desenvolvidos nas décadas de 1950 e 1960 por pesquisadores como Smith [9], Pister, et al. [10], Reissener et al. [11], Stavsky [12], Lekhnitskii [13] e Stavsky, et al. [14] para o cálculo das relações constitutivas de compósitos laminados submetidos a diferentes carregamentos. Esta teoria assume como pressupostos fundamentais o estado plano de tensões em cada uma das camadas e a inexistência de tensões interlaminares. Isto é, as lâminas individuais são perfeitamente aderidas entre si, comportando-se como um elemento unitário, não homogêneo e anisotrópico [6]. Além disso, para o estudo e cálculo de estruturas compósitas com lâminas multidirecionais são necessários dois sistemas de coordenadas, sendo o primeiro relativo aos carregamentos e à geometria da peça e o segundo à orientação das fibras [5], exceto no caso particular de os eixos principais serem sobrepostos.

\subsection{Materiais biológicos}

Entre as categorias de materiais mais tradicionalmente utilizados por seres humanos estão os polímeros e compósitos de origem natural, entre os quais as madeiras e vegetais lenhosos em geral desempenharam papel fundamental ao longo da história das civilizações. $\mathrm{Na}$ atualidade, materiais provenientes de fontes renováveis vem sendo progressivamente mais valorizados em detrimento 
2.

de sintéticos por conta da conscientização ambiental, retomando assim posição de destaque entre os insumos da sociedade contemporânea. Nesse ínterim, a pesquisa e o desenvolvimento de materiais e tecnologias enquadrados nestas características são fundamentais para a geração de produtos condizentes com a resistência, durabilidade, sustentabilidade, reprodutibilidade, acessibilidade e potencial de comercialização, exigidos pela sociedade.

Materiais biológicos são notadamente eficientes. Por eficientes refere-se ao fato de eles atenderem de maneira bem sucedida às complexas imposições da natureza aos seres vivos, e por fazê-lo com o mínimo material possível. A maioria dos materiais naturais é sustentável, reciclável e, quando o despojo é necessário, biodegradável, fazendo deles um modelo de consciência ambiental para a engenharia [15].

De fato os materiais disponíveis na natureza são compósitos, constituídos de um número relativamente pequeno de componentes poliméricos, cerâmicos ou blocos de construção (que invariavelmente são também compósitos).

Paredes celulares de plantas, por exemplo, são compósitos de celulose, hemicelulose, pectina e proteína, podendo ser lignificadas; tecidos animais consistem majoritariamente de colágeno, elastina, queratina, quitina e minerais como sais de cálcio e sílica. A partir destes poucos "ingredientes" a natureza produz uma vasta gama de compósitos estruturados. Do ponto de vista mecânico, estes componentes nada apresentam de extraordinário, sendo na verdade sua estrutura e arranjo os responsáveis pelo seu desempenho [15].

\subsection{Vegetais}

Vegetais lenhosos possuem microestruturas complexas, em face de sua constituição orgânica, procedência natural e composição química, que pode ser variável de acordo com a localização geográfica, clima, tipo de solo e espécie. São materiais porosos, constituídos por diferentes estruturas cujo elemento básico é a célula. Existem vários tipos de células, as quais têm funções diversas no vegetal, tais como, condução da seiva, suporte e armazenamento de substâncias nutritivas. Cada uma dessas funções confere uma forma diferente ás células. Algumas são mais alongadas, outras prismáticas, com razão de aspecto baixa. Umas possuem paredes mais espessas, outras paredes mais finas. Devido a isso, entre si, vegetais lenhosos apresentam características diferentes como permeabilidade, textura, propriedades físicas e mecânicas. Conhecendo-se a microestrutura do material é possível o uso de diferentes 
2.

espécies para as mais diversas aplicações, em especial no campo da construção civil [16].

\subsubsection{Blocos de construção básicos}

A celulose é um polissacarídeo constituído por cadeias de unidades monoméricas glicosídicas, encontrado na natureza em diversos materiais como algodão, bambu e madeira. De alta resistência à tração, a celulose fornece uma estrutura a vegetais lenhosos. Tem alto grau de polimerização, forma fibras e possui regiões cristalinas e amorfas. É o componente de maior importância nas paredes celulares dos vegetais lenhosos, tanto em termos de volume como em relação ao seu efeito nas características físicas, respondendo por cerca de $40 \%$ a $50 \%$ em relação ao peso seco. É possível estimar que a celulose constitui $1 / 3$ do material total produzido por todas as plantas coletivamente, o que torna a mais importante matéria-prima de origem vegetal disponível ao homem [17].

As hemiceluloses são caracterizadas como heteropolissacarídeos complexos consistentes de xilose, glucose, arabinose, galactose, manose, bem como de ácido urônico [18], apresentando-se associadas com a celulose e a lignina em tecidos vegetais. Enquanto a celulose é formada pela repetição da mesma unidade monomérica, nas hemiceluloses aparecem condensadas diversas dessas unidades. Apresentam baixo grau de polimerização, não formam fibras e só possuem regiões amorfas. O conteúdo de hemicelulose num vegetal arbóreo corresponde a cerca de $25 \%$ a $35 \%$, considerando o peso seco. A hemicelulose combina-se à lignina por ligações covalentes e conecta-se à celulose por meio de interligação física/mecânica [19].

A lignina é um composto aromático de alto peso molecular. É um polímero tridimensional e amorfo que consiste em subestruturas metoxiladas de fenil-propano [20] em composições diferentes para os diferentes vegetais lenhosos. A lignina incrusta o espaço intercelular e toda e qualquer abertura e cavidade das paredes celulares, após a deposição da celulose e das hemiceluloses. Atua como material aglomerante que liga os elementos estruturais dos vegetais lenhosos (fibras, traqueídeos e vasos) e auxilia na redução de mudanças dimensionais quando as paredes das células absorvem água. A lignina é bastante insolúvel, apresentando menor higroscopidade (habilidade em absorver água) que a celulose. A mais importante propriedade física deste material é a rigidez e dureza que confere às paredes celulares onde está localizada, ou seja, é a lignina que dá rigidez e dureza ao conjunto de 
2.

cadeia de celulose, conferindo coesão ao compósito natural do qual é componente. Muitas propriedades físicas e mecânicas dos vegetais lenhosos dependem da presença da lignina.

\subsection{Bambu}

O Bambu consiste de um compósito de fibras de celulose inseridas numa matriz de lignina-hemicelulose formada por células prismáticas ocas com espessura de parede variável [15]. Contém cerca de 40 a $48 \%$ de celulose, 25 a $30 \%$ de hemicelulose, e 11 a $27 \%$ de lignina [21]. As fibras de bambu mostram uma estrutura polilamelar com lamelas largas e estreitas, que conferem ao bambu uma resistência elevada à tração [22]. A orientação das fibrilas e a concentração de lignina e xilano, são variáveis na estrutura polilamelar, sendo maior nas lamelas estreitas do que nas largas [23]. Colmos de bambu diferem de madeiras e outras gramíneas em termos de composição química e características da fibra [24].

\subsubsection{Composição química}

A composição química não pode ser precisamente definida para uma espécie de vegetal lenhoso ou mesmo para uma espécie em particular. Ela varia de acordo com uma série de fatores, podendo muitas vezes depender do clima, tipo de solo, procedência (localização geográfica), taxa de crescimento, idade, parte (localização na planta), teor de extrativos, microambiente e influenciam a resistência dos bambus [25]. Bambus têm pouca resina, cera, ou teor de tanino, nenhum dos quais oferece efeito protetor suficiente na durabilidade natural [26] [27]. O teor de carboidratos de bambu tem um papel importante em sua durabilidade [27]. Acredita-se que a presença de açúcar, amido e o teor de proteína o tornam suscetíveis a fungos, e muitos insetos [26] [28] [29] [30], porque eles são excelentes substratos para os organismos de degradação [31]. Colmos consistem em cerca de 45 a $55 \%$ de células do parênquima, que são preenchidos com amido (2 a 6\%), açúcar (2\%), proteína (1.5 a 6\%) e gordura (2 a $4 \%$ ), mesmo em colmos mais velhos [30]. De qualquer forma, pode-se afirmar que existem três componentes principais na estrutura dos bambus: Lignina (18\% a 35\%), Hemicelulose e Celulose (65\% a 75\%). Esses materiais são considerados polímeros (polissacarídeos) complexos. Como um todo, os 
2.

elementos (estrutura molecular) que compõem vegetais lenhosos são aproximadamente distribuídos da seguinte forma:

- $50 \%$ carbono;

- $44 \%$ oxigênio;

- $6,0 \%$ hidrogênio;

- Traços de muitos íons metálicos.

\subsubsection{Caracterização multidimensional}

A caracterização multidimensional, assistida por diversas técnicas de microscopia, propicia a compreensão da organização desses materiais desde a identificação e morfologia dos seus tecidos e cálculos gerais de frações volumétricas até a distribuição de suas células e a avaliação da presença de certos componentes químicos em sua composição (Figura 1). Para o sucesso deste tipo de estudo, diversas técnicas de preparação de amostras são utilizadas, para cada tipo de análise a ser executada em cada tipo de aparelho.

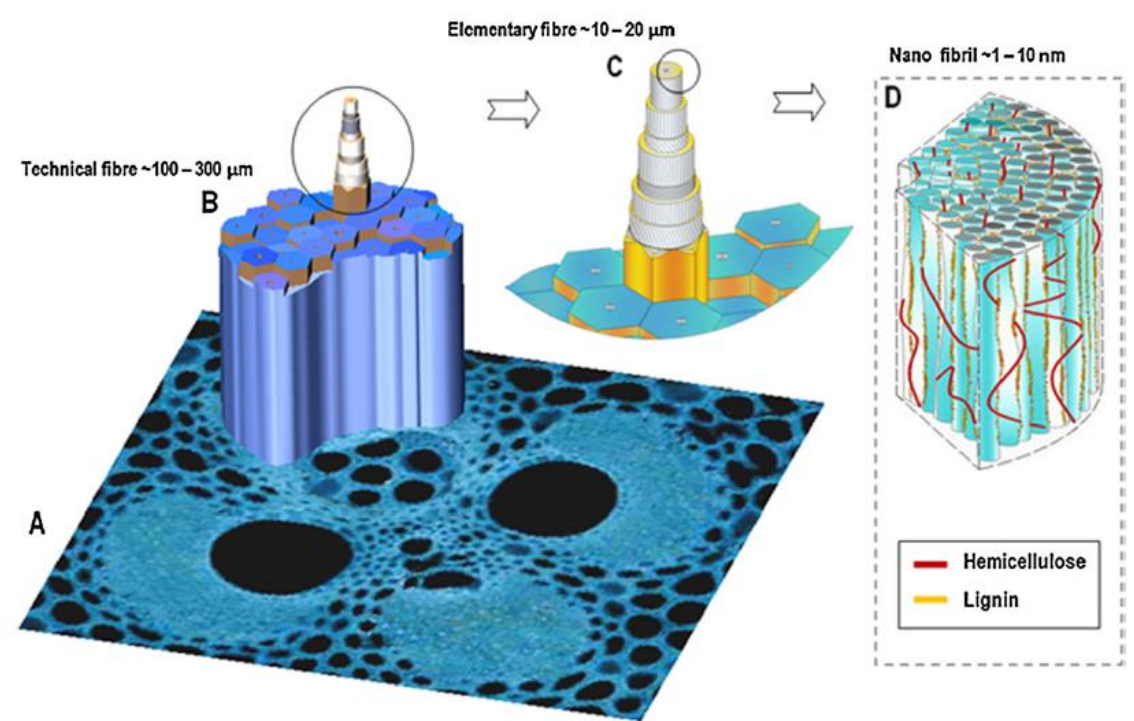

Figura 1: Diagrama esquemático da estrutura de uma fibra de bambu [32]. Em tradução livre: B: Fibra técnica $\sim 100-300 \mu \mathrm{m}$; C: Fibra elementar $10-20 \mu \mathrm{m}$; D: Nano fibrilas $~ 1-10 \mathrm{~nm}$.

\subsubsection{Microscopia ótica}

Embora o advento das lentes eletrônicas tenha feito com que a microscopia ótica (MO) fosse deixada de lado em estudos estruturais, a descoberta da versatilidade desse instrumento, combinada com a facilidade de 
2.

uso e preparo da amostra, fazendo dele uma ferramenta indispensável para a análise estrutural.

A microscopia ótica baseia-se na configuração ótica na qual o material fica localizado em frente ao plano focal da objetiva e a luz transmitida (MOLT) através da imagem, ou refletida (MOLR) da porção central do espécime em observação, produz raios paralelos que se projetam pelo eixo ótico do microscópio até as lentes (oculares). A porção de luz que chega até a objetiva, originária da periferia do material em observação, é conduzida através das lentes do tubo e então focada numa imagem plana intermediária, que é então ampliada pelas oculares [33].

A aplicação mais comum da microscopia ótica é a iluminação de campo brilhante em que a luz é transmitida por baixo através de um pequeno pedaço ou seção de material. A imagem é formada acima da amostra num tubo e vista por uma ocular com o tamanho ampliado e aproximadamente 10 a 100 vezes. As amostras são examinadas à pressão atmosférica normal e não precisam ser desidratadas. Além disso, a preparação de amostras é relativamente fácil. Um dos recursos mais comuns da microscopia ótica de campo iluminado é aplicar tintura ou corante para aumentar o contraste ou diferenciar tecidos. Na microscopia ótica, a coloração é um processo útil porque tecidos biológicos são comumente incolores e não oferecem contraste [34].

\subsubsection{Microscopia eletrônica de varredura}

A microscopia eletrônica de varredura (MEV) é usada para examinar superfícies. A amostra é seca (MEV convencional) ou congelada abaixo de $80^{\circ} \mathrm{C}$ (cryo-MEV). Uma camada fina, denominada coating ou cobertura, que pode ser de metal (em geral ouro) ou de carbono, responsável pela condutividade elétrica, é pulverizada sobre a amostra para que esta possa ser visualizada. As imagens geradas pela técnica de MEV possuem bom foco e intensidade e são relativamente fáceis de serem entendidas [35].

O MEV destina-se basicamente ao exame de superfície das amostras, sendo que as superfícies internas das amostras também podem ser visualizadas desde que a amostra seja fraturada e exposta. Ótimos resultados de fratura são conseguidos com o congelamento da amostra empregando-se nitrogênio líquido e posterior fratura manual. Uma ampla faixa de aumentos pode ser usada (20x100.000x) e a MEV pode alcançar uma profundidade de campo aproximadamente 500 vezes maior que a microscopia ótica [34]. A resolução do 
2.

microscópio eletrônico de varredura é de 10 nanômetros. As aplicações do microscópio eletrônico de varredura incluem desde estudo de organismos inteiros, tecidos e órgãos, até em certos casos, visualização in situ de organelas subcelulares. $O$ interesse maior é obter informações topográficas. A grande vantagem deste instrumento é a elevada profundidade de campo, da ordem de $10 \mu \mathrm{m}$ para aumentos de cerca de 10.000 vezes, chegando a $1 \mathrm{~cm}$ para aumentos de 20 vezes. Esta característica possibilita obter imagens estereoscópicas e bem enfocadas com amostras até macroscópicas. Além disso, no MEV a amostra pode ser inclinada e rotacionada sob o feixe eletrônico em todas as orientações, logo precisa estar bem preservada nas três dimensões [35].

Este tipo de microscópio é constituído de canhão eletrônico, lentes, circuito de varredura, coletor e ampliador de sinais, tubo de raios catódicos, sistema de vácuo, registro de imagens, controles [34].

O MEV usa elétrons que se dispersam ou são emitidos a partir da superfície da amostra. O feixe de elétrons é localizado dentro de uma pequena sonda que passa rapidamente para frente e para trás sobre a amostra. $\mathrm{O}$ rastreamento completo de cima abaixo geralmente leva apenas alguns segundos. As diferenças na superfície da amostra afetam o padrão com o qual os elétrons são dispersos a partir deste. Buracos ou fissuras aparecem escuros, as protuberâncias e saliências aparecem claras, resultando em uma imagem tridimensional [35].

\subsubsection{Propriedades mecânicas}

Como todo material natural o bambu tem alterações em suas características mecânicas devido a uma infinidade de fatores como a espécie, idade da planta, tempo de corte e fatores que fogem ao controle humano como condições climáticas, teor de umidade das amostras, solo do bambuzal. Sendo a idade, a espécie e região do colmo importantes variáveis para a determinação de suas propriedades.

Para o dimensionamento correto do bambu em peças estruturais é de fundamental importância o conhecimento das tensões decorrentes da ação de várias forças a que estas estarão submetidas. A resistência atingida diz respeito não somente à resistência do material, mas aos defeitos que debilitam as seções. Os corpos-de-prova são, em geral, confeccionados conforme normas do 
2.

INBAR (1999) - ISO 22157 [4] e propostas de ensaios elaboradas por Ghavami [36].

A estrutura fibrosa, em feixes, do bambu favorece a resistência à tração axial, porém, quando solicitado axialmente, raramente rompe por tração pura [37]. A principal causa disto reside nas tortuosidades dos feixes e nas mudanças de seções, geralmente nos nós, onde se interrompem as fibras, se reduzem às áreas resistentes e originam-se, na peça, solicitações secundárias de compressão normal, cisalhamento e fendilhamento, às quais o material oferece menor resistência. Segundo Beraldo, et al. [38], a resistência à tração axial do bambu, em algumas espécies, pode atingir $370 \mathrm{MPa}$. Em geral a resistência à tração axial do bambu, com e sem nó, situa-se entre $40 \mathrm{MPa}$ e $215 \mathrm{MPa}$, e o seu módulo de elasticidade varia entre 5,5 GPa e $18 \mathrm{GPa}$.

Em ensaios conduzidos por Ghavami, et al. [39], conclui-se que à resistência das diversas porções não difere substancialmente. Entretanto, nas regiões inferiores, pela seção transversal maior, são conseguidas cargas últimas maiores. Sendo o nó um ponto de descontinuidade das fibras e de mudanças dimensionais, surgem nele concentrações de tensões quando submetido a esforços. Ghavami, et al. [39] observaram, em ensaios de tração, que na maioria dos testes a ruptura ocorreu próximo ao nó, e que a parte basal apresentou maior carga de ruptura por ter maior seção transversal.

A curva tensão-deformação específica nos ensaios de compressão é quase linear. A resistência à compressão situa-se na faixa de 20,0 MPa a $120 \mathrm{MPa}$ e o módulo de elasticidade varia entre 2,60 GPa e 20,0 GPa [38]. Ghavami, et al. [40] estudaram as propriedades mecânicas do bambu Phyllostachys pubescens tratado e cru, e obtiveram valores de 49,3 MPa para o bambu cru e 31,0 MPa para o bambu tratado, o que corresponde a uma queda de $37,2 \%$ na resistência à compressão. O módulo de elasticidade longitudinal as fibras foi de 10,3 GPa e 8,77 GPa para os bambus cru e tratado respectivamente, o que representa uma queda de $14,6 \%$.

Segundo Janssen [41], a resistência ao cisalhamento do bambu ao longo das fibras é somente de cerca de $8 \%$ da resistência à compressão. Grosser et al. [42] afirmam que a resistência ao cisalhamento aumenta com a diminuição da espessura da parede, ou seja, da base para o topo da peça do bambu. Argumentam que a porcentagem de esclerênquima (tecido de sustentação do bambu, elemento que proporciona resistência ao material) aumenta com a diminuição da espessura da parede. A resistência ao cisalhamento transversal às fibras do bambu situa-se em torno de $30 \%$ de sua resistência à flexão, ou 
2.

seja, em torno de 32,0 MPa (variando entre 20,0 MPa e $65 \mathrm{MPa}$ ). A resistência ao cisalhamento interlaminar é de, aproximadamente, $15 \%$ de sua resistência à compressão, ou seja, em torno de 6,00 MPa, com variação de 4,00 a 10,0 MPa [38]. Lee, et. al. [43], estudaram as características mecânicas da espécie Phyllostachys bambusoide, utilizando amostras de $14,0 \mathrm{~cm}$ de diâmetro médio e comprimento aproximado de $9 \mathrm{~m}$. Foram realizados ensaios de flexão, tração e compressão seguindo as recomendações da ASTM D-1037 [44] em 376 elementos de bambu verdes e 371 secos ao ar.

\subsubsection{Resistência e módulo de elasticidade à tração}

No que diz respeito a propriedades mecânicas, bambus, em geral são notadamente resistentes à tração, dado o alinhamento das suas fibras celulósicas e a maneira como elas se distribuem na matriz celular parenquimatosa.

Diferentes espécies foram pesquisadas, por pesquisadores diversos, considerando parametros como a posição no colmo e na espessura da parede, bem como a presença ou não de diafragmas nos corpos-de-prova. A Tabela 1 apresenta alguns dos ensaios já realizados, seus autores, a posição de onde foram obtidos os corpos-de-prova e os valores obtidos para ensaios de tração longitudunal em bambus. 
2.

Tabela 1: Comparativo entre propriedades mecânicas à tração de bambus de diversas espécies, de acordo com sua posição no colmo/parede e região (nodal ou internodal).

\begin{tabular}{|c|c|c|c|c|c|c|}
\hline Espécie & Referência & $\begin{array}{l}\text { Posição } \\
\text { no colmo }\end{array}$ & $\begin{array}{l}\text { Posição } \\
\text { na parede }\end{array}$ & Região & $\sigma_{\text {máx }}(\mathrm{Mpa})$ & E (Gpa) \\
\hline \multirow{4}{*}{$\begin{array}{l}\text { Dendrocalamus } \\
\text { strictus }\end{array}$} & \multirow{4}{*}{ Ahmad [45] } & \multirow[t]{2}{*}{ base } & \multirow[t]{2}{*}{ completa } & nó & $\begin{array}{l}\text { 106,20 } \\
\text { (méd.) }\end{array}$ & $\begin{array}{l}17,70 \\
\text { (méd.) }\end{array}$ \\
\hline & & & & internó & 156,14 & 16,80 \\
\hline & & \multirow[t]{2}{*}{ meio } & \multirow[t]{2}{*}{ completa } & nó & $\begin{array}{l}\text { 106,20 } \\
\text { (méd.) }\end{array}$ & $\begin{array}{l}\text { 17,70 } \\
\text { (méd.) }\end{array}$ \\
\hline & & & & internó & 185,30 & 12,70 \\
\hline $\begin{array}{l}\text { Phyllostachys } \\
\text { pubescens }\end{array}$ & Yu et al. [46] & $\begin{array}{l}\text { não } \\
\text { verificada }\end{array}$ & $\begin{array}{l}\text { não } \\
\text { verificada }\end{array}$ & internó & $\begin{array}{l}115,30 \text { a } \\
309,30\end{array}$ & 9 a 27,4 \\
\hline \multirow{4}{*}{$\begin{array}{l}\text { Guadua } \\
\text { weberbaueri }\end{array}$} & \multirow{4}{*}{ Murad [47] } & \multirow{4}{*}{ base } & \multirow{2}{*}{ interna } & nó & 57,10 & 5,62 \\
\hline & & & & internó & 200 & 5,67 \\
\hline & & & \multirow{2}{*}{ externa } & nó & 87,40 & 7,76 \\
\hline & & & & internó & 312 & 9,13 \\
\hline \multirow{3}{*}{$\begin{array}{l}\text { Phyllostachys } \\
\text { bambusiodes }\end{array}$} & \multirow{3}{*}{$\begin{array}{l}\text { Lee, et al. } \\
{[48]}\end{array}$} & base & \multirow{3}{*}{ completa } & \multirow{3}{*}{ internó } & 110,83 & \multirow{3}{*}{-} \\
\hline & & meio & & & 118,25 & \\
\hline & & topo & & & 131,10 & \\
\hline \multirow{6}{*}{$\begin{array}{l}\text { Guadua } \\
\text { angustifolia }\end{array}$} & \multirow{6}{*}{$\begin{array}{l}\text { Ghavami, et } \\
\text { al. [49] }\end{array}$} & \multirow{2}{*}{ base } & \multirow{6}{*}{ completa } & nó & 69,90 & 15,70 \\
\hline & & & & internó & 93,80 & 16,30 \\
\hline & & \multirow{2}{*}{ meio } & & nó & 82,60 & 11,10 \\
\hline & & & & internó & 95,80 & 18,10 \\
\hline & & \multirow{2}{*}{ topo } & & nó & 64,30 & 11,20 \\
\hline & & & & internó & 116 & 18,40 \\
\hline \multirow{4}{*}{$\begin{array}{l}\text { Guadua } \\
\text { superba }\end{array}$} & \multirow{4}{*}{$\begin{array}{l}\text { Ghavami, et } \\
\text { al. [50] }\end{array}$} & \multirow{2}{*}{ base } & & nó & 109 & 8,33 \\
\hline & & & complats & internó & 143 & 10,50 \\
\hline & & & completa & nó & 116 & 9,42 \\
\hline & & topo & & internó & 151 & 11,80 \\
\hline & & & & nó & 103 & 16,90 \\
\hline & & base & & internó & 240 & 20,10 \\
\hline & Pereira [51] & mein & comnleta & nó & 118 & 18,60 \\
\hline & rerema [0I] & meio & compreta & internó & 250 & 20,70 \\
\hline & & & & nó & 114 & 19,50 \\
\hline & & topo & & internó & 247 & 20,70 \\
\hline & & haco & & nó & 109 & 13,60 \\
\hline & & oase & & internó & 159 & 23,10 \\
\hline Dendrocalamus & Ghavami, et & mein & completa & nó & 170 & 20,80 \\
\hline giganteus & al. [52] & melo & completa & internó & 224 & - \\
\hline & & & & nó & 119 & 18,30 \\
\hline & & topo & & internó & 147 & - \\
\hline & & & & nó & 107 & 13 \\
\hline & & base & & internó & 147 & 19,10 \\
\hline & Ghavami, et & & & nó & 144 & 16,70 \\
\hline & al. [50] & meio & completa & internó & 188 & 15,70 \\
\hline & & & & nó & 114 & 13,40 \\
\hline & & topo & & internó & 158 & 10,70 \\
\hline
\end{tabular}

\subsubsection{Resistência ao cisalhamento}

Ghavami, et al. [53] realizaram ensaios de cisalhamento interlaminar do bambu da espécie Guadua angustifólia. Na base, a resistência ao cisalhamento 
2.

foi de 2,20 MPa para o corpos-de-prova sem nó e 1,67 MPa para o corpos-deprova com nó. Na região intermediária os valores foram 2,27 MPa e 1,43 MPa para corpos-de-prova sem e com nó, respectivamente. No topo, estes valores foram de 2,20 MPa para corpos-de-prova sem nó e 1,67 MPa para corpos-deprova com nó. Observa-se que nos corpos-de-prova sem nó a resistência é maior e se mantém quase uniforme nas três partes, já nas partes com nó a resistência é menor e os valores variam muito. Ghavami, et al. [52] obtiveram para a espécie Dendrocalamus giganteus a resistência ao cisalhamento de 4,20 MPa para os corpos-de-prova sem nó e 3,60 MPa para o corpos-de-prova com nó da região superior. Na região intermediária os valores foram 4,20 MPa e 3,24 MPa para corpos-de-prova sem e com nó, respectivamente. Na base, estes valores foram 3,24 MPa para corpos-de-prova sem nó e 2,34 MPa para corposde-prova com nó. Observa-se que nos corpos-de-prova sem nó a resistência é maior e se mantém quase uniforme nas três partes, já nas partes com nó a resistência é menor e os valores variam muito.

\subsubsection{Resistência à compressão}

Murad [47] obteve valores de resistência à compressão de 54,50 $\mathrm{MPa}$ e 37,33 MPa para os corpos-de-prova sem e com nó, respectivamente. Ghavami, et al. [49] ensaiaram o bambu Guadua angustifólia e encontraram valores para a resistência à compressão de 28,4 MPa, 31,8 MPa e 25,3 MPa para os corposde-prova sem nó, para as regiões da base, meio e topo, respectivamente. Para as mesmas regiões, com a presença de nós, 25,3 MPa, 28,4 MPa e 31,8 MPa. De modo similar e para a mesma espécie de bambu e em regiões internodais, Correal, et al. [54] obtiveram 36,8 MPa, 36,6 MPa e 36,8 MPa em média para as regiões da base, meio e topo, respectivamente. Pereira [55] obteve para a espécie Dendrocalamus giganteus a resistência à compressão de 71,5 MPa para o corpos-de-prova sem nó e 65,5 MPa para o corpos-de-prova com nó da região superior. Na região intermediária os valores foram 70,8 MPa e 65,4 MPa para corpos-de-prova sem e com nó respectivamente. Na base, estes valores foram 68,5 MPa para corpos-de-prova sem nó e 9,1 MPa para corpos-de-prova com nó. Ghavami, et al. [52] determinaram a resistência à compressão do bambu Dendrocalamus giganteus e obtiveram valores de 71,4 MPa e 72,6 MPa em corpos-de-prova com e sem nó, respectivamente, para a região basal. Na região intermediária os valores foram 70,8 MPa e 65,4 MPa para corpos-de-prova sem 
2.

e com nó, respectivamente. No topo, esses valores foram de 71,5 MPa para corpos-de-prova sem nó e 65,6 MPa para corpos-de-prova com nó.

\subsection{Caracterização das lâminas}

Bambus, de qualquer espécie, configuram materiais extremamente anisotrópicos, dadas as suas irregularidades naturais e características intrínsecas. Dentre as características intrínsecas ao material está a funcionalidade graduada, uma propriedade inerente aos tecidos duros produzidos pela natureza. Está estabelecido que tecidos duros como ossos, conchas e determinados vegetais (como o bambu), desenvolvem sua estrutura de acordo com as imposições do ambiente natural e construído, moldando sua resistência e geometria de modo a obter a relação ótima para o funcionamento global do sistema do qual fazem parte. Sendo assim diz-se que a estrutura do bambu é constituída de forma auto-otimizada, de modo a resistir eficientemente aos esforços impostos em cada direção, sendo graduada através da sensibilidade eletromecânica de suas células (de maneira similar ao efeito piezoelétrico nos ossos) a solicitações externas [56]. A graduação funcional se processa, no bambu, através da sensibilidade eletromecânica de suas células a solicitações externas, denominada efeito piezoelétrico ("eletricidade de pressão") [57].

A gradação funcional do bambu pode ser percebida através de uma análise macro / mesoestrutural de uma seção de colmo. Nota-se a variação da fração volumétrica de feixes de fibras na direção radial pela a maior concentração no anel externo e sua gradual diminuição conforme a aproximação do anel interno. Em uma seção de bambu percebe-se claramente que a densidade das fibras não é uniforme, sendo mais elevada na periferia exterior. A resistência à tração das fibras é de cerca de $600 \mathrm{MPa}$, cerca de 12 vezes superior à resistência da matriz [58], portanto, a resistência do material é proporcional à fração volumétrica de fibras. Autores diversos estudaram esta variação de fibras para diversas espécies de bambu. Amada, et al. [59] trabalharam com bambus da espécie Phyllostachys edulis comparando a posição no colmo a características morfológicas como o comprimento internodal, o diâmetro e a espessura da parede, como também à fração volumétrica de fibras. No mesmo trabalho foi estudada a variação desta fração em relação ao eixo radial do bambu, observando maior densidade na zona exterior (60 a 65\%), 
2.

escassez (15 a 20\%) na região interna e um aumento linear com a altura de cerca de 20 a $40 \%$ [59].

Para o uso em laminados esta é uma característica fundamental, uma vez que influencia diretamente nas propriedades mecânicas do compósito que se pretende engenheirar. De uma maneira geral, ensaios mecânicos de bambu são conduzidos em corpos-de-prova que compreendem a espessura total do colmo, avaliando cortes radiais. Entretanto, para a confecção de laminados estruturais são utilizados cortes na direção tangencial do material, dos quais somente são aproveitadas as camadas mais próximas à face externa da parede do colmo.

Verma, et al. [60] procederam a ensaios à tração de lâminas extraídas tangencialmente de bambus da espécie Dendrocalamus strictus, em três pontos da espessura, obtendo os resultados sumarizados na Tabela 2.

Tabela 2: Propriedades mecânicas à tração de lâminas de bambu Dendrocalamus strictus para uso em laminados estruturais (adaptado de Verma, et al., 2013)

\begin{tabular}{l|l|l|l|l|l|l|l|}
\hline \multirow{2}{*}{$\begin{array}{l}\text { Posição } \\
\text { na parede } \\
\text { do colmo }\end{array}$} & Propriedade & \multicolumn{2}{l}{ Número do internó } \\
\cline { 3 - 9 } & Rigidez (GPa) & 4.6 & 5.9 & 6.4 & 5.23 & 6.93 & 8.9 \\
\hline $\begin{array}{l}\text { Região } \\
\text { externa }\end{array}$ & Resistência (MPa) & 240 & 257 & 250 & 281 & 298 & 302 \\
\hline \multirow{2}{*}{$\begin{array}{l}\text { Região } \\
\text { central }\end{array}$} & Rigidez (Gpa) & 4.63 & 6.2 & 6.3 & 6.6 & 6.3 & 7.56 \\
\cline { 2 - 9 } & Resistência (Mpa) & 175 & 173 & 204 & 226 & 230 & 276 \\
\hline \multirow{2}{*}{$\begin{array}{l}\text { Região } \\
\text { interna }\end{array}$} & Rigidez (Gpa) & 2.1 & 2.5 & 2.7 & 3.63 & 3.7 & 4.66 \\
\cline { 2 - 9 } & Resistência (Mpa) & 101 & 104 & 169 & 172 & 217 & 212 \\
\hline
\end{tabular}

Utilizando esses resultados Verma, et al. [60] calcularam as relações constitutivas via Regra das Misturas simplificada para materiais ortotrópicos e procederam à análise teórica a partir da teoria clássica de laminados.

\subsection{Laminados de bambu}

Embora existam várias publicações sobre caracterização de compósitos à base de fibras de bambu de bambu inseridas matriz polimérica [61] [62] [63] [64] [65] [66] [67] [68], muito pouco é relatado sobre a avaliação de compósitos laminados de bambu na literatura [69] [70] [71] [60] [72]. Propriedades à tração, 
2.

compressão e flexão de laminados à base de bambu precisam ser investigados exaustivamente de modo a que o potencial de bambu como um compósito funcionalmente graduado possa ser adequadamente utilizado [71].

Verma, et al. [72] Investigaram lâminas e laminados com cinco camadas, coladas entre si com adesivo epóxi, em 3 diferentes arranjos, sendo um unidirecional, um com camadas longitudinais e a $45^{\circ}$ e um com camadas longitudinais e transversais, conduzindo ensaios de tração, compressão e flexão, analisando suas propriedades mecânicas e modos de falha (Figura 2).
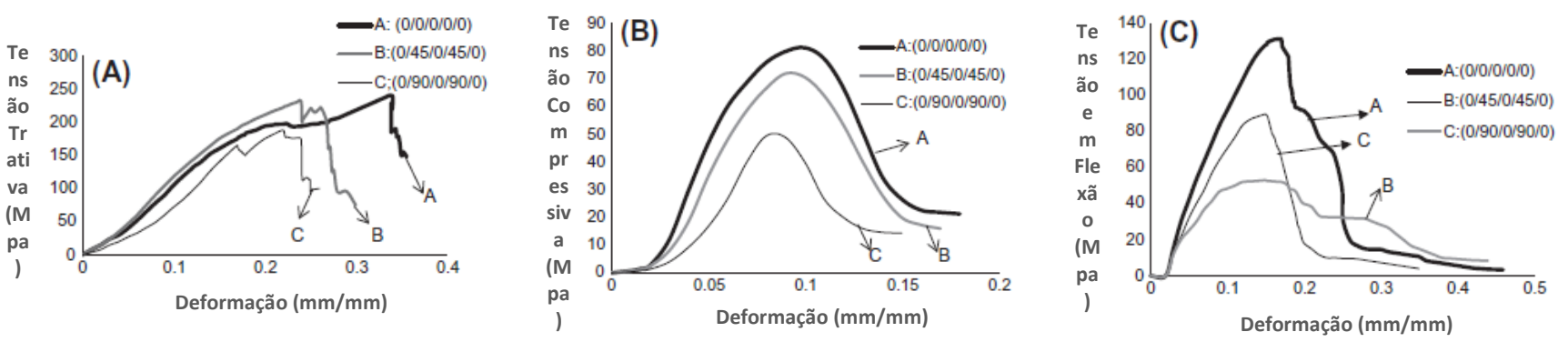

Figura 2: Gráficos tensão x deformação a (A) tração, (B) Compressão e (C) flexão, obtidos por Verma et al. [72].

Verma et al. [60] desenvolveram também laminados com 4 camadas unidirecionais, ensaiando-os à tração e desenvolvendo uma análise matricial, baseada nos resultados. A Figura 3 exibe os resultados dos ensaios.

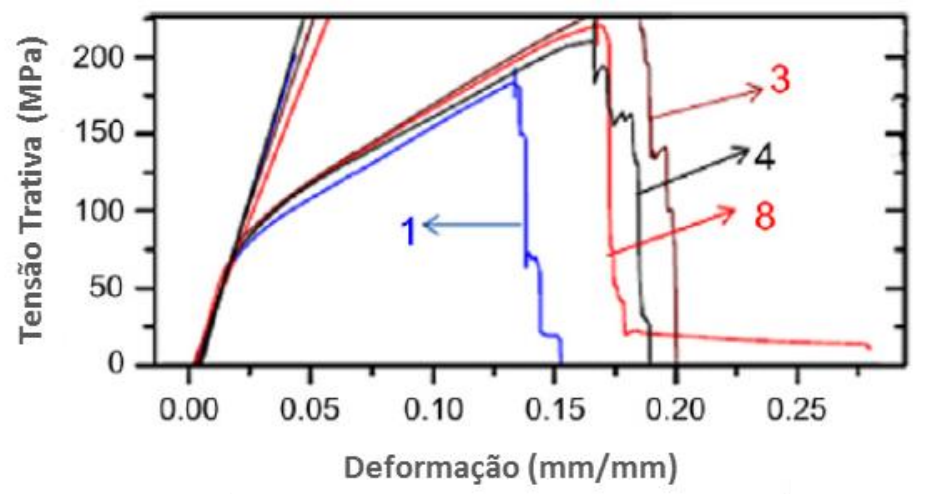

Figura 3: Graficos tensão x deformação à tração de laminados de bambu com 4 camadas [60].

No Brasil ocorrem espécies de bambu, tais como, Dendrocalamus giganteus e o Bambusa vulgaris, com potencial adequado para a fabricação de laminados de bambu, em especial do bambu laminado colado (BLC). O fator 
2.

limitante dessas espécies para a produção do BLC refere-se à inexistência de equipamentos adequados para realizar a laminação das taliscas.

O processo de obtenção do BLC encontra-se ainda restrito ao nível de pesquisas dentro das universidades brasileiras, sendo os primeiros resultados apresentado por Carrasco, et al. [73]. Os autores confeccionaram BLC, da espécie D. giganteus, utilizando o mesmo adesivo usualmente empregado para madeira laminada e colada. Lapo, et al. [74] buscaram seguir as mesmas normas adotadas para a madeira, adaptando-as ao bambu para a confecção dos corpos-de-prova e para a realização de ensaios. Visando contribuir para o aprimoramento do estudo do BLC, Gonçalves, et al. [75] apresentaram recomendações para a confecção dos corpos-de-prova e relataram resultados obtidos em ensaios de caracterização mecânica desse material.

As amostras de bambu laminado colado (BLC), quando comparadas às espécies de madeira de mesma faixa de densidade, apresentaram valores bem superiores de resistência à flexão e à tração paralela as fibras. Valores próximos ou pouco superiores foram observados para as propriedades de resistência à compressão paralela, cisalhamento e dureza [76].

O BLC pode ser considerado um material leve com massa específica aparente situada na faixa de $0,50 \mathrm{~g} / \mathrm{cm}^{3}$ a $0,75 \mathrm{~g} / \mathrm{cm}^{3}$. Observou-se tendência de que o BLC de resorcinol-formaldeído (adesivo naval) tenha se mostrado mais estável dimensionalmente do que o BLC de uréia-formaldeído. A impermeabilização da superfície do BLC deve ser buscada visando sua proteção contra as intempéries. A análise estatística indicou a influência das variáveis testadas (espécies de bambu, tipos de tratamentos e de adesivos) e de suas interações nas propriedades do BLC. Não foi possível evidenciar a melhor combinação entre as variáveis (espécie de bambu, tratamento químico e tipo de adesivo) e que atendesse a todas as propriedades avaliadas do BLC [77].

O estudo comparativo entre os diferentes tipos de adesivos demonstrou que o adesivo poliuretano à base de óleo de mamona se mostrou bastante eficiente podendo, em determinadas situações, mostrar-se competitivo com os adesivos comerciais. No entanto, visando uma utilização estrutural, a aplicação do adesivo não deverá ser feita com o auxílio de um pincel. Deve-se efetuar a mistura dos dois componentes em um saco plástico, sem a presença de ar e, com o auxílio de uma bisnaga, deve-se efetuar a aplicação do mesmo sobre as réguas de bambu, evitando-se, assim, a formação de bolhas de ar, que provocarão enfraquecimento da linha de cola do BLC [74]. 
2.

Em maio de 2014 a ASTM publicou revisão da norma D5456 de Avaliação de Produtos de Compósitos Estruturais de Madeira Laminada [78], incluindo procedimentos específicos para LVB (Laminated Veneer Bamboo - Laminado de Folheado de Bambu). Na norma define-se LVB como um elemento estrutural, no qual as fibras estão alinhadas predominantemente ao longo da maior direção, o que pressupõe seu uso em peças unidimensionais. As lâminas que o compõem devem ter o comprimento no mínimo 300 vezes maior que a dimensão da menor direção (em geral a espessura), que por sua vez deve ser menor ou igual a $6,4 \mathrm{~mm}$. A norma orienta ainda que sejam realizados ensaios para a determinação do módulo de cisalhamento de acordo com a ASTM D-198 [79], ensaios para a avaliação do adesivo, retenção de pregos e estabilidade dimensional (inchamento).

Apesar destas recomendações, não há ainda um protocolo estabelecido de ensaios para as lâminas que compõem tais laminados, o que, considerando a classificação funcional do bambu é de extrema importância, a julgar que o trecho da parede do colmo de onde são extraídas as lâminas tem total influência em suas propriedades físicas e mecânicas, dando origem a laminados com propriedades igualmente diferentes. Ademais, esta classificação funcional permite que se obtenham diversos materiais com características distintas, a partir de uma única fonte, podendo atender a um largo espectro de demandas estruturais específicas, com maior produtividade e melhor aproveitamento. Isto ocorre, pois, na direção radial do colmo, as frações volumétricas dos constituintes e dos vazios seguem funções de variação, cuja tendência aponta, no sentido interno-externo, para crescimento do teor de fibras e decremento dos de matriz e de vazios, proporcionando portanto materiais mais leves, quando obtidas de seções mais internas e mais resistentes, quando de seções mais externas. A porosidade tem influência direta nas propriedades físicas do material e não foi ainda quantificada adequadamente, nem correlacionada cientificamente com as propriedades mecânicas, o que priva o estudo de laminados de bambu de informações básicas sobre os seu constituinte principal.

A literatura científica ainda não registrou o aproveitamento das diversas camadas do bambu para o uso de laminados, voltando o seu foco somente para a avaliação de compósitos mais resistentes, o que ocasiona grande desperdício de material de boa qualidade e, em geral com boas propriedades específicas vantajosas, o que é consideravelmente valorizado na indústria aeroespacial por exemplo. Este trabalho pretende concatenar pesquisas de base acerca da avaliação morfológica das lâminas de bambu e da quantificação e 
2.

estabelecimento das funções de variação das frações volumétricas dos constituintes sólidos e dos vazios que caracterizam sua classificação funcional, com protocolos práticos de ensaios mecânicos tanto para a avaliação do material em seu estado natural e de lâminas extraídas de posições distintas em relação ao seu eixo radial. Propõe ainda a confecção de laminados com empacotamentos diferenciados, a partir da combinação entre lâminas extraídas de diferentes pontos da parede do colmo. 


\section{3.}

\section{Materiais utilizados e métodos para a obtenção, preparo e produção das lâminas e laminados de bambu}

\subsection{Introdução}

Neste capítulo tratar-se-á da descrição da metodologia de obtenção, preparo e produção dos materiais utilizados, incluindo a apresentação de gabaritos e ferramentas (inexistentes no mercado) especialmente desenvolvidos para possibilitar a efetivação de determinadas etapas do processo utilizados nesta Tese.

\subsubsection{Bambu}

Foram utilizados bambus da espécie Dendrocalamus giganteus. A touceira de bambu em questão encontra-se no mesmo campus que abriga a sede do grupo de pesquisa em materiais e tecnologias não-convencionais da PUC-Rio (GNOCMAT), sendo monitorada, tratada e manejada com objetivo de atender à pesquisa acadêmica desde a sua plantação em 1979 (Figura 4).
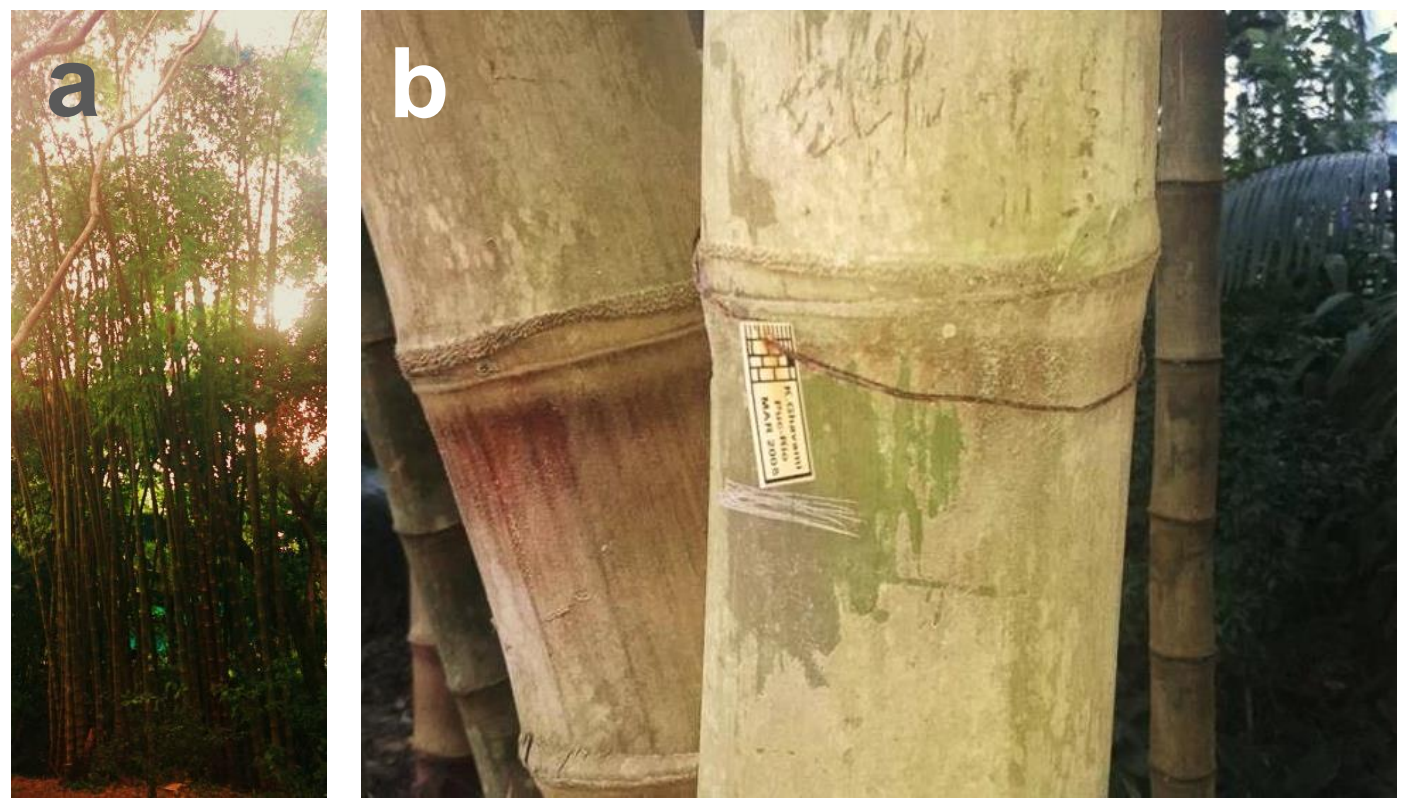

Figura 4: a) Bambuzal manejado na PUC-Rio, desde 1979. b) Placas de marcação para acompanhamento da idade dos colmos. 
3. Materiais utilizados e métodos para a obtenção, preparo e produção das lâminas e laminados de bambu

Os bambus foram colhidos no campus da PUC-Rio em outubro de 2012, com seis anos de idade. Os colmos secaram naturalmente por três meses apoiados ao bambuzal, sendo retirados para processamento em janeiro de 2013. Os colmos não passaram por qualquer tratamento subsequente, tendo iniciado o seu procedimento experimental em outubro de 2013. Depois de retirados da touceira os colmos foram cortados em segmentos de cerca de $4 \mathrm{~m}$ e os internós foram numerados da base para o topo, considerando o trecho abaixo do corte (de modo que a numeração em geral inicia-se em 3 ou 4). Uma segunda colheita foi realizada em outubro de 2013, extraindo indivíduos de idade similar e seguindo procedimento semelhante de secagem. O colmo proveniente desta colheita recebeu tratamento contra insetos xilófagos, dado o alto índice de infestação observado nas colheitas anteriores.

Para a confecção dos corpos-de-prova de controle, a seção ensaiada sempre contempla em uma das dimensões a espessura completa da parede do colmo, independente da geometria final. Os formatos dos corpos-de-prova e o detalhamento dos procedimentos de ensaios serão detalhados no capítulo de ensaios mecânicos de controle (Capítulo 5).

\subsubsection{Lâminas}

Para permitir a obtenção de lâminas sequenciais, ortogonais ao eixo radial do bambu, fundamentais para a caracterização do bambu como material compósito funcionalmente graduado, além de ferramentas comuns de marcenaria, como serra circular de bancada, serra de esquadria, tupia de bancada e desengrosso projetou-se e construiu-se uma máquina com o intuito de permitir a divisão de seções longitudinais do colmo em lâminas, seja no eixo radial ou em planos perpendiculares a ele (Figura 5). A referida máquina tira partido do alinhamento das fibras do bambu e de sua resistência inferior ao cisalhamento longitudinal e atua empurrando por meio de um rolo trator e um posicionador, um prisma retangular longitudinal de bambu contra uma lâmina fixa, que pode ter sua altura ajustada de acordo com o tamanho da peça original gerando perda desprezível de material, frente a outros processos, como fresamento ou desengrossamento. Para a obtenção de uma peça final aparelhada de bambu (lâmina), entretanto, não são dispensados processos convencionais de marcenaria, com as ferramentas citadas anteriormente. 
3. Materiais utilizados e métodos para a obtenção, preparo e produção das lâminas e laminados de bambu
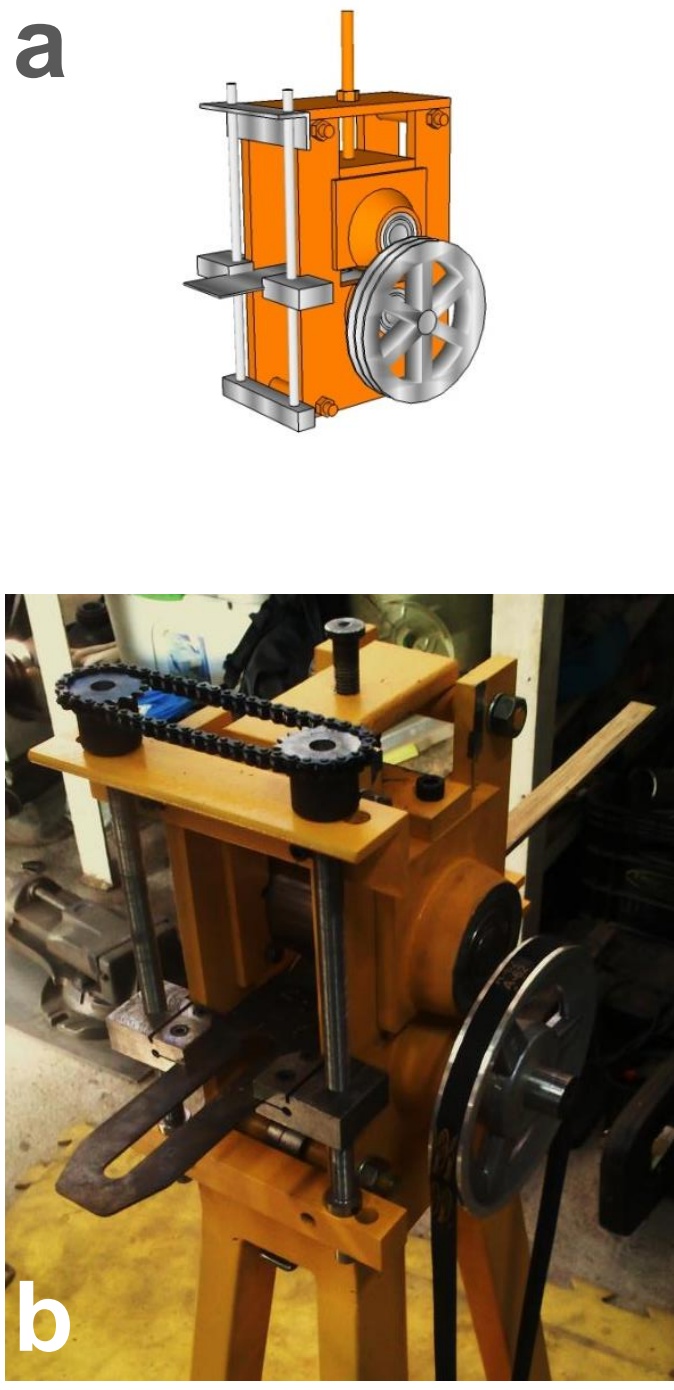

Figura 5: a) Desenho original. b) Maquina em teste. c) Configuração final da divisora de lâminas de bambu - 1: regulagem de altura/posicionamento da lâmina divisora; 2: regulagem da pressão da mola; 3: lâmina divisora; 4: cilindro estabilizador; 5: mesa de entrada do material a ser laminado; 6: polia fixada ao cilindro trator; 7 : motor bifásico 1/2 HP.

Sistematizando o processo para a obtenção das lâminas observou-se a necessidade de 6 etapas (Figura 6), detalhadas a seguir: 
3. Materiais utilizados e métodos para a obtenção, preparo e produção das lâminas e laminados de bambu
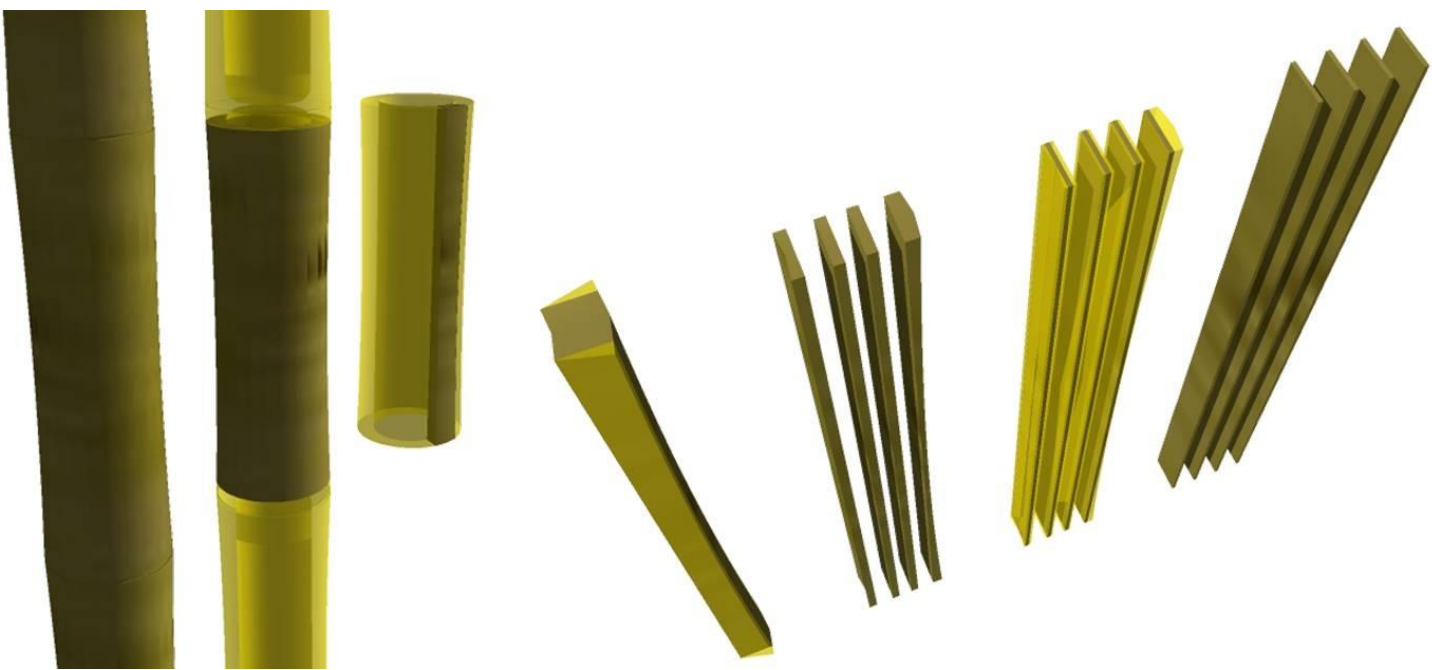

Figura 6: Processo de obtenção das lâminas de Dendrocalamus giganetus a partir do colmo completo: separação dos Internós e descarte dos diafragmas; cortes longitudinais para a obtenção das réguas; aparelhamento lateral das réguas; divisão das réguas e aparelhamento final das lâminas.

1. Cortes transversais, de modo a separar as regiões internodais a serem utilizadas, dos diafragmas a serem dispensados. Utiliza-se para isso uma serra de esquadria elétrica, com diâmetro de serra de widea de 12 ", regulada a $90^{\circ}$ (corte reto);

2. Cortes radiais longitudinais para a obtenção das réguas. Realizados com gabarito de centralização em "V" (Figura 7) acoplado a uma serra circular de bancada;

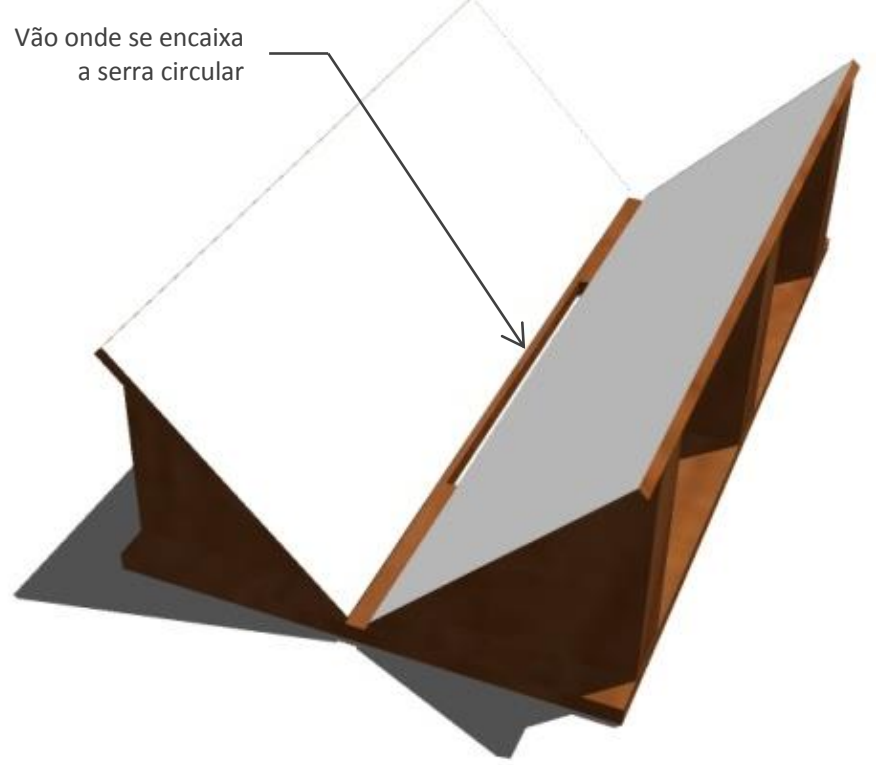

Figura 7: Gabarito de centralização para serra circular de bancada. 
3. Materiais utilizados e métodos para a obtenção, preparo e produção das lâminas e laminados de bambu

3. Aparelhamento transversal de uma das faces laterais das réguas. Utiliza-se uma tupia de bancada com um cilindro de lâmina tripla, alinhado a uma guia paralela, garantindo perpendicularidade (entre a mesa e as lâminas);

4. Corte em serra circular de bancada com guia paralela, tomando por referência a face aparelhada na etapa anterior, estabelecendo a largura desejada para a régua (a mesma pretendida para a lâmina acabada, no caso $20 \mathrm{~mm}$ );

5. Divisão da parede em cortes tangenciais, utilizando a divisora especificamente confeccionada para esta função;

6. Aparelhamento das lâminas até a espessura desejada (no caso 2 $\mathrm{mm}$ ), utilizando plaina desengrossadeira, garantindo paralelismo.

É importante trabalhar com marcações adequadas após a etapa 5, de modo a manter o controle sobre a ordem e o posicionamento das lâminas.

As réguas provenientes das regiões basal, medial e apical do bambu são divididas respectivamente em 4, 3 e 2 lâminas, por conta do aproveitamento máximo permitido pela espessura do colmo.

\subsubsection{Adesivo}

O adesivo utilizado para confeccionar os laminados é uma resina a base de poliuretano vegetal (originado do óleo de mamona), bi-componente, 100\% sólido (isento de solventes), formulado pela mistura a frio de um pré-polímero (A) e um poliol (B) [80], denominada comercialmente Imperveg UG 132A.

\subsubsection{Laminados}

Para a produção dos laminados optou-se por utilizar somente porções mediais do colmo, de modo a não perder o controle da origem das lâminas e evitar combinações excessivas. Deste modo é levada em consideração a posição da lâmina em relação à espessura da parede, sendo diferenciadas em camadas: interna, central e externa. Assim, é possível variar os empacotamentos, considerando os requerimentos de uso, variando artificialmente a fração volumétrica das fibras.

Foram produzidos 4 empacotamentos distintos de lâminas, utilizando os internós numerados 13 e 14 obtidos da porção medial do colmo. Cinco unidades de cada tipo de laminado foram confeccionadas: resistente (lâminas externas), médio (lâminas mediais), leve (lâminas internas) e balanceado (lâminas internas no núcleo e lâminas externas nas camadas externas). Para manter a uniformidade de cada série de laminados, os empacotamentos foram produzidos 
3. Materiais utilizados e métodos para a obtenção, preparo e produção das lâminas e laminados de bambu

de acordo com a Tabela 3. No total foram utilizadas 20 réguas provenientes do internó 14 e 20 provenientes do internó 13.

Tabela 3: Empacotamentos de laminados: a) Resistente; b) Médio; c) Leve; d) Balanceado.

\begin{tabular}{|c|c|c|c|c|c|}
\hline Empacotamentos & CP1 & CP2 & CP3 & CP4 & CP5 \\
\hline Resistente & \multicolumn{5}{|c|}{ Réguas externas provenientes dos internós 13 e 14} \\
\hline 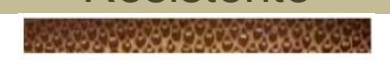 & $14 \mathrm{E}_{1}$ & $14 \mathrm{E}_{2}$ & $14 \mathrm{E}_{3}$ & $14 \mathrm{E}_{4}$ & $14 \mathrm{E}_{5}$ \\
\hline - & $14 \mathrm{E}_{6}$ & $14 \mathrm{E}_{7}$ & $14 \mathrm{E}_{8}$ & $14 E_{9}$ & $14 \mathrm{E}_{10}$ \\
\hline 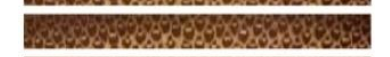 & $13 E_{1}$ & $13 E_{2}$ & $13 E_{3}$ & $13 E_{4}$ & $13 E_{5}$ \\
\hline 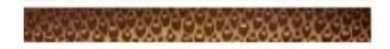 & $14 \mathrm{E}_{11}$ & $14 \mathrm{E}_{12}$ & $14 \mathrm{E}_{13}$ & $14 \mathrm{E}_{14}$ & $14 \mathrm{E}_{15}$ \\
\hline KWow & $14 \mathrm{E}_{16}$ & $14 \mathrm{E}_{17}$ & $14 \mathrm{E}_{18}$ & $14 \mathrm{E}_{19}$ & $14 \mathrm{E}_{20}$ \\
\hline Médio & \multicolumn{5}{|c|}{ Réguas mediais provenientes dos internós 13 e 14} \\
\hline $2080,8000090.09090009$ & $14 M_{1}$ & $14 M_{2}$ & $14 \mathrm{M}_{3}$ & $14 M_{4}$ & $14 M_{5}$ \\
\hline $200,8900000.0900009$ & $14 M_{6}$ & $14 M_{7}$ & $14 M_{8}$ & $14 \mathrm{M}_{9}$ & $14 \mathrm{M}_{10}$ \\
\hline 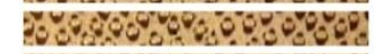 & $13 M_{1}$ & $13 M_{2}$ & $13 M_{3}$ & $13 M_{4}$ & $13 M_{5}$ \\
\hline 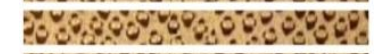 & $14 M_{11}$ & $14 M_{12}$ & $14 \mathrm{M}_{13}$ & $14 M_{14}$ & $14 \mathrm{M}_{15}$ \\
\hline 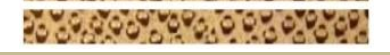 & $14 M_{16}$ & $14 M_{17}$ & $14 \mathrm{M}_{18}$ & $14 \mathrm{M}_{19}$ & $14 \mathrm{M}_{20}$ \\
\hline Leve & \multicolumn{5}{|c|}{ Réguas internas provenientes dos internós 13 e 14} \\
\hline 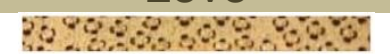 & $14 I_{1}$ & $14 I_{2}$ & $14 I_{3}$ & $14 I_{4}$ & $14 I_{5}$ \\
\hline 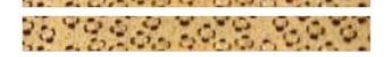 & $14 I_{6}$ & $14 I_{7}$ & $14 I_{8}$ & $14 l_{9}$ & $14 I_{10}$ \\
\hline $20.95285698 .80 \%$ & $13 I_{1}$ & $13 I_{2}$ & $13 I_{3}$ & $13 I_{4}$ & $13 I_{5}$ \\
\hline 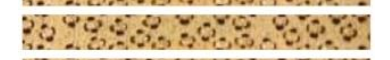 & $14 I_{11}$ & $14 I_{12}$ & $14 I_{13}$ & $14 I_{14}$ & $14 I_{15}$ \\
\hline $7020965060.80 \% 5$ & $14 I_{16}$ & $14 I_{17}$ & $14 I_{18}$ & $14 I_{19}$ & $14 I_{20}$ \\
\hline Balanceado & \multicolumn{5}{|c|}{ Réguas externas e internas provenientes do internó 13} \\
\hline 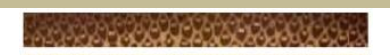 & $13 \mathrm{E}_{6}$ & $13 \mathrm{E}_{7}$ & $13 E_{8}$ & $13 \mathrm{E}_{9}$ & $13 \mathrm{E}_{10}$ \\
\hline $70.0546060 .89 \%$ & $13 I_{6}$ & $13 I_{7}$ & $\left.13\right|_{8}$ & $\left.13\right|_{8}$ & $13 \mathrm{I}_{10}$ \\
\hline 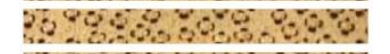 & $13 I_{11}$ & $13 l_{12}$ & $\left.13\right|_{13}$ & $13 I_{14}$ & $13 I_{15}$ \\
\hline 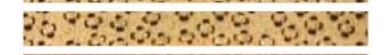 & $13 I_{16}$ & $13 I_{17}$ & $13 \mathrm{I}_{18}$ & $13 I_{19}$ & $13 I_{20}$ \\
\hline 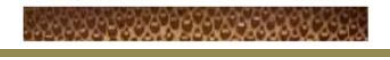 & $13 \mathrm{E}_{11}$ & $13 E_{12}$ & $13 E_{13}$ & $13 E_{14}$ & $13 \mathrm{E}_{15}$ \\
\hline
\end{tabular}

No processo de colagem utiliza-se uma prensa manual e um gabarito de polipropileno para manter o alinhamento das lâminas e evitar a adesão do poliuretano e permitir o uso continuado (Figura 8). $O$ gabarito permite a prensagem conjunta de 10 corpos-de-prova de flexão. 
3. Materiais utilizados e métodos para a obtenção, preparo e produção das lâminas e laminados de bambu
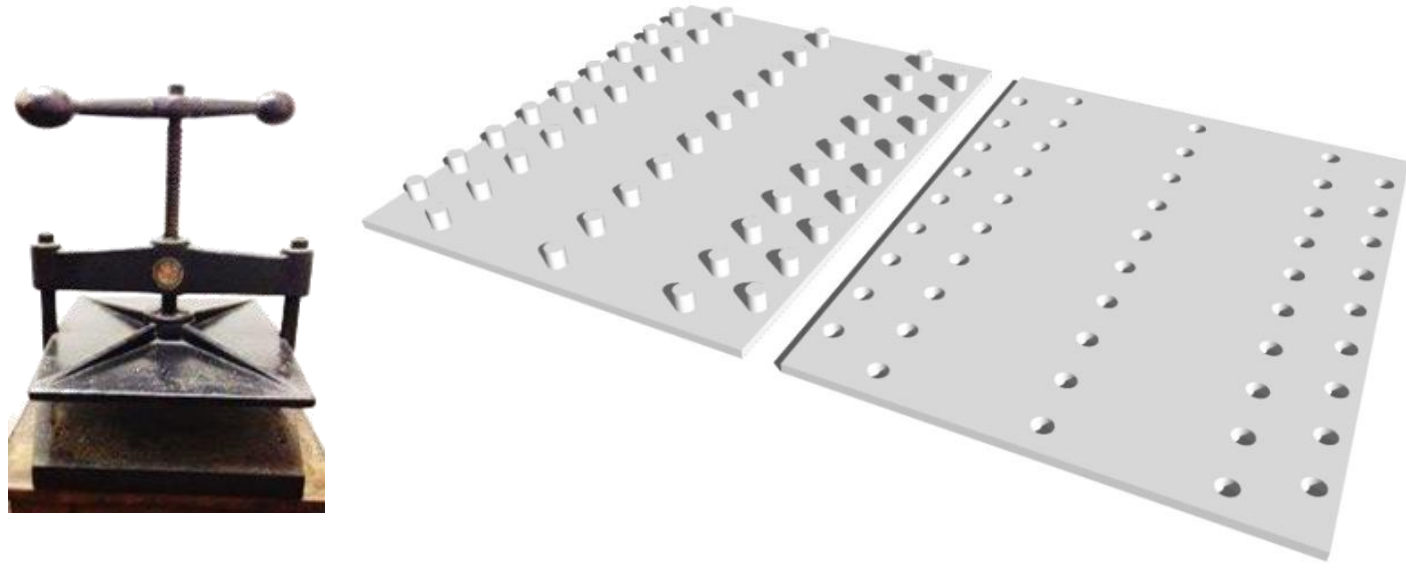

Figura 8: Prensa manual em ferro fundido e gabarito de prensagem em polipropileno. 


\section{4. \\ Caracterização multidimensional dos materiais estudados}

\subsection{Introdução}

A caracterização de materiais naturais, fundamentamente vegetais lenhosos, para uso estrutural pode ser aproximada partindo das regras de mistura comumente usadas para materiais compósitos. Entretanto estes materiais apresentam uma série de propriedades específicas, relacionadas com sua morfologia orgânica, em diferentes escalas. O bambu, especificamente, apresenta características tais como: na escala macroscópica: conicidade, presença de diafragmas, variação da espessura das paredes do colmo e do espaço internodal em relação à altura; na escala meso: variação na fração volumétrica dos feixes de fibras ao longo do eixo radial; na escala micro: variação na fração volumétrica das fibras, matriz e vazios (principalmente a porosidade do parênquima) ao longo do eixo radial e na escala nano: variação na orientação das fibrilas na composição das lamelas constituintes das fibras.

Este trabalho se propõe a caracterizar lâminas e compósitos estruturais laminados de bambu para uso estrutural, de modo que as particularidades nanoestruturais estão fora do parâmetro de caracterização, bem como algumas das características macroscópicas, como a conicidade e as variações de espessura das paredes e comprimento de espaços internodais.

Para a caracterização das lâminas de bambu como material compósito funcionalmente graduado nas regiões internodais é necessário avaliar não somente as frações volumétricas de fibras, matriz e vazios, como também a sua variação em relação ao eixo radial. Para tanto faz-se necessário um procedimento de visualização, com fator de aumento suficiente para permitir a observação dos vazios em suas diversas apresentações: vasos condutores de seiva bruta e elaborada; porosidade do parênquima (matriz); falhas entre as fibrilas e lúmens (região central das fibrilas). Devido ao fator de aumento requerido, não existe possibilidade de obter a visualização simultânea de toda a espessura da parede do bambu, fator fundamental para a avaliação da variação da fração volumétrica das fibras, da matriz e dos vazios. Para obter uma micrografia que possibilite a visualização simultânea da espessura total do colmo 
4.

e dos vazios referentes à matriz e às fibras é necessário montar um mosaico a partir de uma série de imagens. Por outro lado, o procedimento de microtomografia permite obter a visualização completa, com resolução suficiente para proceder ao cômputo das frações volumétricas, tomando como referência o cômputo dos vazios do parênquima.

\subsubsection{Caracterização morfológica}

Para a caracterização morfológoca do material, diversas técnicas são utilizadas, dado o caráter de complementaridade que possuem entre si. Nesta pesquisa são utilizadas as técnicas de estereoscopia, microscopia ótica de luz transmitida e refletida, microscopia eletronica de varredura, tomografia e microtomografia.

\subsubsection{Microscopia ótica de luz transmitida (MOLT)}

As amostras para MOLT, provieram da colheita de 2012 e foram processadas através de ultramicrotomia no Centro de Ciências da Saúde na UFRJ (CCS), preparadas e dispostas em lâminas para a observação em microscópio ótico. As imagens foram obtidas em um microscópio ótico Zeiss Axioimager M2.m, com câmera digital Zeiss AxioCam MRc5, no Departamento de Engenharia de Materiais da PUC-Rio (DEMa).

Para o procedimento de MOLT as amostras não são separadas em relação à sua posiçao no colmo, pois sua dimensão final não permite obter dados quantitativos representativos (em relação ao que se deseja observar neste trabalho), de modo que as análises provenientes desta técnica, nesta tese, são exclusivamente qualitativas.

Preparação das amostras: A partir de um bloco de $10 \mathrm{~mm}$ (circunferencial) x $15 \mathrm{~mm}$ (radial) x $50 \mathrm{~mm}$ (longitudinal) extraem-se, com o auxílio de uma serra tico-tico manual, recortes de cerca de $1 \mathrm{~mm} \times 1 \mathrm{~mm} \times 1 \mathrm{~mm}$. Tais recortes são então posicionados em um ultramicrótomo em duas orientações diferentes, de tal modo que seja possível obter fatias transversais e longitudinais às fibras. As fatias, com aproximadamente $1 \mu \mathrm{m}$ de espessura, são posicionadas em uma gota de água bi-destilada em lâminas de vidro, de acordo com a sua orientação e divididas em dois grupos. Um dos grupos recebe um procedimento de coloração com azul de toluidina. Em seguida uma gota de elileno glicol e uma 
4.

lamínula de proteção são dispostas em cada lâmina de vidro, concluindo a preparação das amostras.

\subsubsection{Estereoscopia e Microscopia ótica de luz refletida (MOLR)}

Para os procedimentos de MOLR e estereoscopia são separadas amostras em relação ao posicionamento na parede do colmo (internas e externas). As amostras são cubos de cerca de $5 \mathrm{~mm} \times 5 \mathrm{~mm} \times 5 \mathrm{~mm}$, obtidos a partir de uma régua de bambu Dendrocalamus giganteus (colhido em 2013) com cerca de 15 $\mathrm{cm}$ de comprimento, $0,5 \mathrm{~cm}$ de espessura (circunferencial ao colmo) e com a espessura total da parede (inferior a $15 \mathrm{~mm}$ ). Cortes de $5 \mathrm{~mm}$ são realizados transversalmente às fibras com uma serra circular de bancada e na sequência, as porções mais externa e mais interna da parede são separadas a $5 \mathrm{~mm}$ dos extremos, com o auxílio de uma lâmina nova de estilete. Os blocos são impregnados a vácuo com uma resina epóxi de embutimento Epofix, com adição de corante fluorescente Epodye, ambos da marca Struers. O bloco é lixado em lixadeira orbital, com granatura sequencialmente mais fina e então polido com pasta de diamante em politriz orbital.

A preparação e as visualizações foram realizadas no Centro de Tecnologia Mineral (CETEM). Foi utilizado um microscópio ótico Zeiss Axioimager M2.m, com câmera digital Zeiss AxioCam MRc5, lente objetiva Zeiss EC Epiplan 5x (Abertura Numérica $=0,13$ ). As imagens de campo claro foram obtidas com iluminação por lâmpada halógena de $100 \mathrm{~W}$. As fluorescências foram geradas submetendo as amostras impregnadas com resina corada à iluminação LED de comprimento de onda $445 \mathrm{~nm}$, Zeiss Colibri 2 e observadas mediante um conjunto de filtros Zeiss $38 \mathrm{HE}$. As estereoscopias foram conduzidas em um Estereomicroscópio Zeiss Stereo Discovery.V8, com câmera digital Zeiss AxioCam MRc5.

\subsubsection{Microscopia eletrônica de varredura (MEV)}

As amostras para Microscopia Eletrônica de Varredura foram obtidas a partir de exemplares de base, meio e topo de colmos da espécie Dendrocalamus giganteus, provenientes da colheita de 2012, processadas e observadas no Laboratório de Metalografia do Departamento de Engenharia de Materiais da PUC-Rio (DEMa). Os blocos são extraídos de anéis de bambu (Figura 9a e b) com o auxílio de uma lâmina larga de estilete efetuando cortes paralelos 
4.

longitudinais às fibras com cerca de $5 \mathrm{~mm}$ de distância entre si. Em seguida é realizado um corte transversal às fibras, gerando um bloco de $5 \mathrm{~mm} \times 5 \mathrm{~mm} \times$ espessura do colmo (Figura 9c). Os blocos, de base, meio e topo, são lixados em lixadeira orbital, com granatura sequencialmente mais fina e então polidos com pasta de diamante em politriz orbital, de modo a homogeneizar suas superfícies de visualização. Para possibilitar o procedimento (condução de elétrons) as amostras receberam um cobrimento (coat) de ouro (Figura 9d).
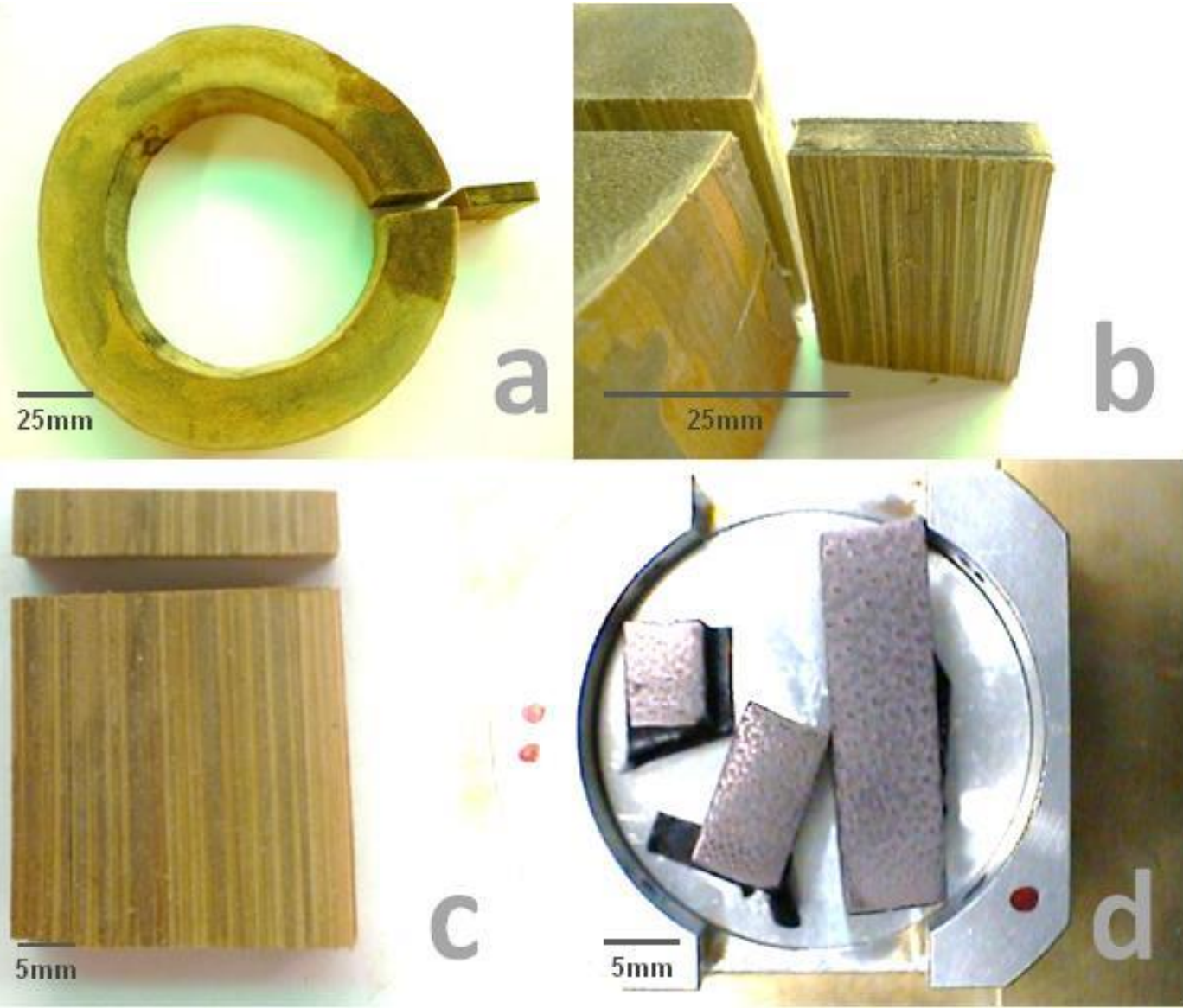

Figura 9: a) Anel de região internodal de bambu para a obtenção de amostra a ser observada em MEV. b) Detalhe da seção do anel para a obtenção da amostra. c) Detalhe do corte do tamanho final para a amostra. d) Amostras extraídas das regiões apical, medial e basal após o coat de ouro.

\subsubsection{Tomografia}

No intuito de avaliar tridimensionalmente a organização e a quantificação das fibras ao longo do colmo de bambu, foram elaboradas amostras com e sem diafragma, provenientes das porções de base (internó 6, nó 6/7), meio (internó 16 , nó $16 / 17$ ) e topo (internó 34 , nó $34 / 35$ ), para visualização por tomografia 
4.

computadorizada (Figura 10), a partir de material colhido em 2012. Trata-se do mesmo material a partir do qual foram confeccionados os corpos-de-prova para os ensaios mecânicos de controle. As amostras consistem de blocos de $20 \mathrm{~mm} x$ $20 \mathrm{~mm} \times$ espessura da parede do colmo, sem qualquer tratamento especial.

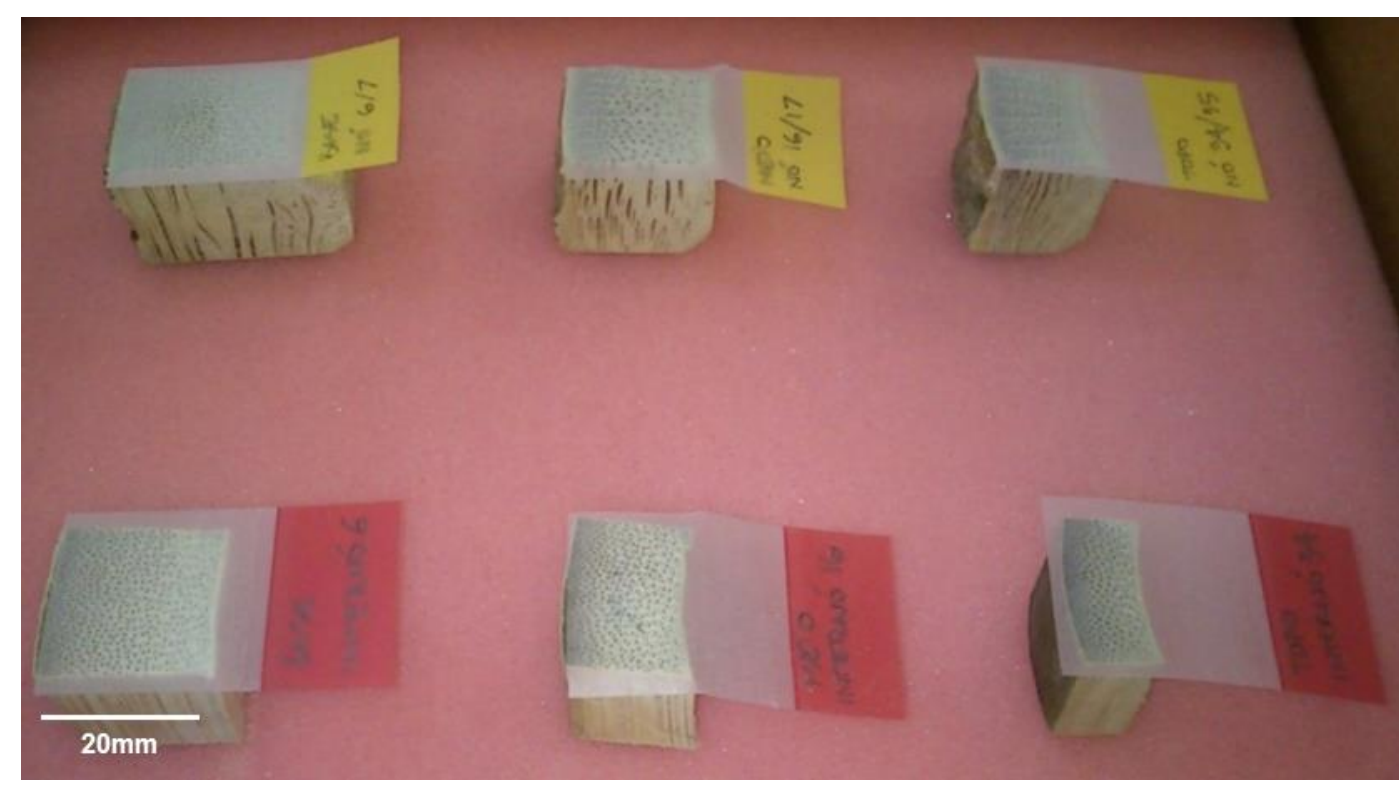

Figura 10: Amostras de bambu da espécie Dendrocalamus giganteus, com (amarelo) e sem (vermelho), diafragma, das regiões basal (à esquerda), central e apical (à direita), para tomografia computadorizada.

As tomografias foram realizadas na Fundação Centros de Referência em Tecnologias Inovadoras CERTI, em Florianópolis Santa Catarina em um tomógrafo de aplicação industrial Zeiss, modelo Metrotom 1500, assistido por uma Máquina de Medição Tridimensional por Coordenadas Zeiss, modelo Prismo Ultra Super Accuracy e um Digitalizador Ótico GOM, modelo Smart Scan.

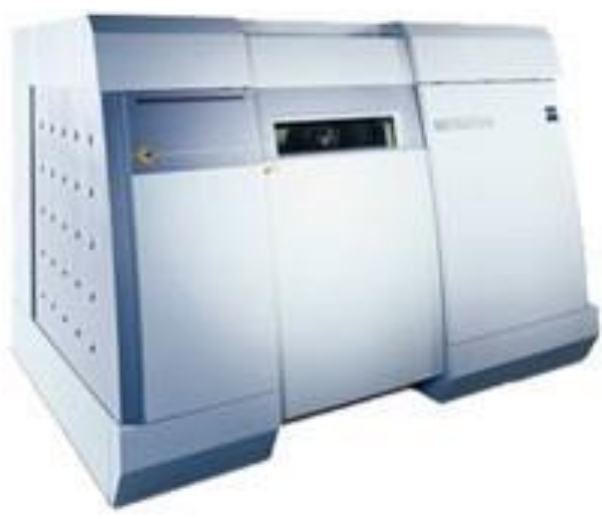

Figura 11: Tomógrafo de aplicação industrial Zeiss, modelo Metrotom 1500 [81]. 
4.

Para a extração da matriz de voxel nas tomografias foram utilizados os seguintes parâmetros: 120 kV de tensão, com corrente de $220 \mu \mathrm{A} ; 700$ projeções com tempo de exposição de 1 segundo; ampliação de 10x, usando lente de 16x; detector de binning com 1024x1024 pixels, dimensão de voxel de $40 \mu \mathrm{m}$ e dimensão pontual de $26 \mu \mathrm{m}$. No processamento digital das imagens obtidas, foi utilizado o Filtro Shepp log noise suppression.

\subsubsection{Microtomografia}

No intuito de quantilicar as fases do bambu em diferentes porções do colmo e localizações em relação à espessura da parede 9 amostras de $2 \mathrm{~mm}$ de espessura (radial), $5 \mathrm{~mm}$ de largura (longitudinal) e $10 \mathrm{~mm}$ de comprimento (circunferencial) foram confeccionadas, obtidas das mesmas lâminas de onde foram retirados os corpos-de-prova de tração (lâminas), do seguinte modo:

- Porção basal (internó 6 Dendrocalamus giganteus 2013) - Interna, Medial-Interna, Medial-externa e Externa;

- Porção medial (internó 16 Dendrocalamus giganteus 2013) Interna, Medial e Externa;

- Porção apical (internó 34 Dendrocalamus giganteus 2013) - Interna e Externa.

As amostras foram coladas à cabeça de alfinetes de costura (Figura 12a) para facilitar seu posicionamento no Microtomógrafo (Figura 12b). 
4.
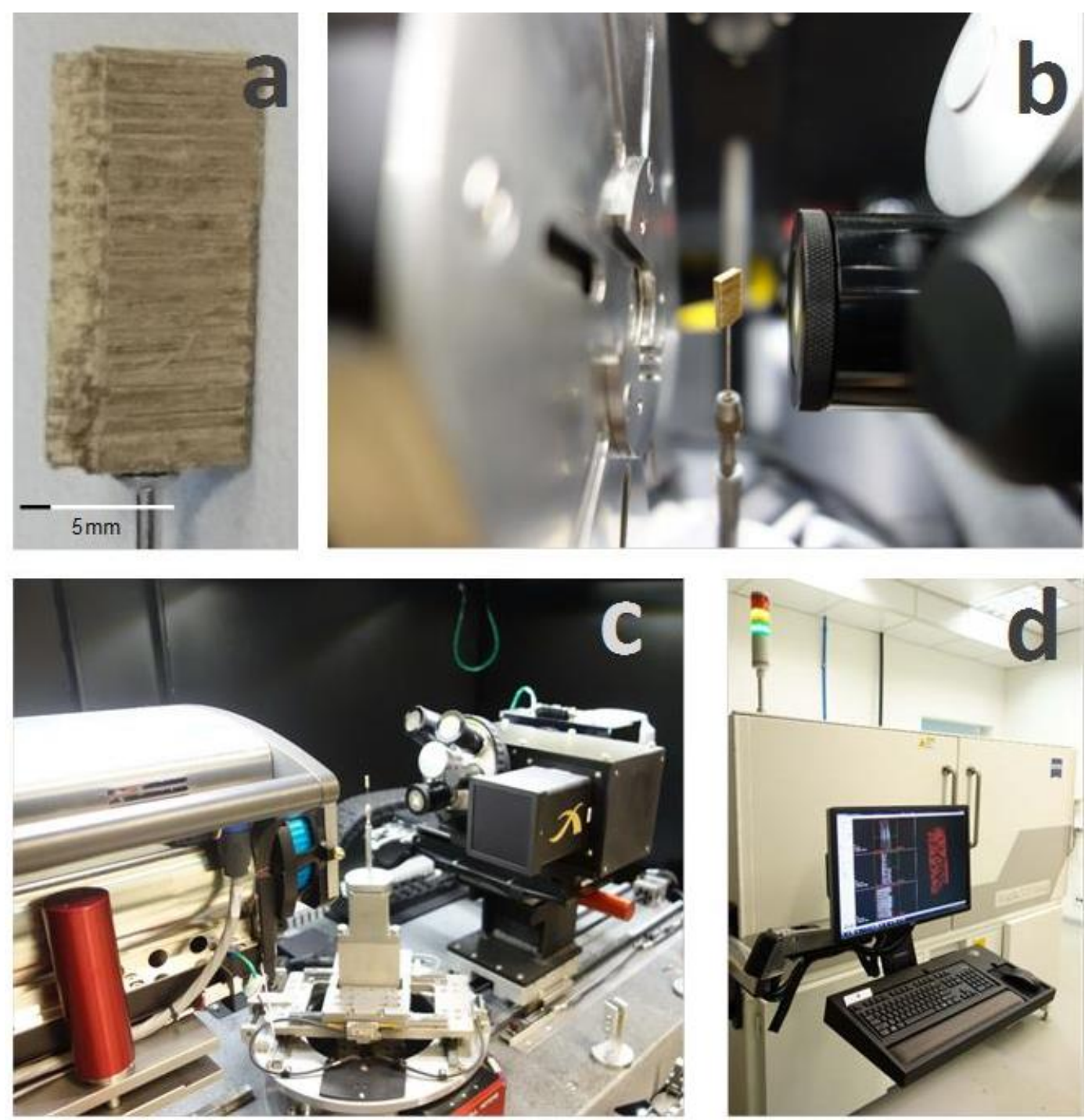

Figura 12: a) Amostra de bambu para microtomografia afixada à cabeça de um alfinete. b) da esquerda para a direita: fonte de raios $X$; amostra de bambu; lente de 4x. c) fonte; amostra; detector e conjunto de lentes d) Microtomógrafo Zeiss Xradia 510 Versa [82].

As microtomografias foram conduzidas no Laboratório de Processamento Digital de Imagens da PUC-Rio, em um Microtomógrafo ZEISS Xradia 510 Versa. Os parâmetros utilizados para a extração da matriz de voxel estão consolidados na caixa de diálogo do software de controle próprio do tomógrafo (Figura 13) e traduzidos livremente na Tabela 4. 
4.

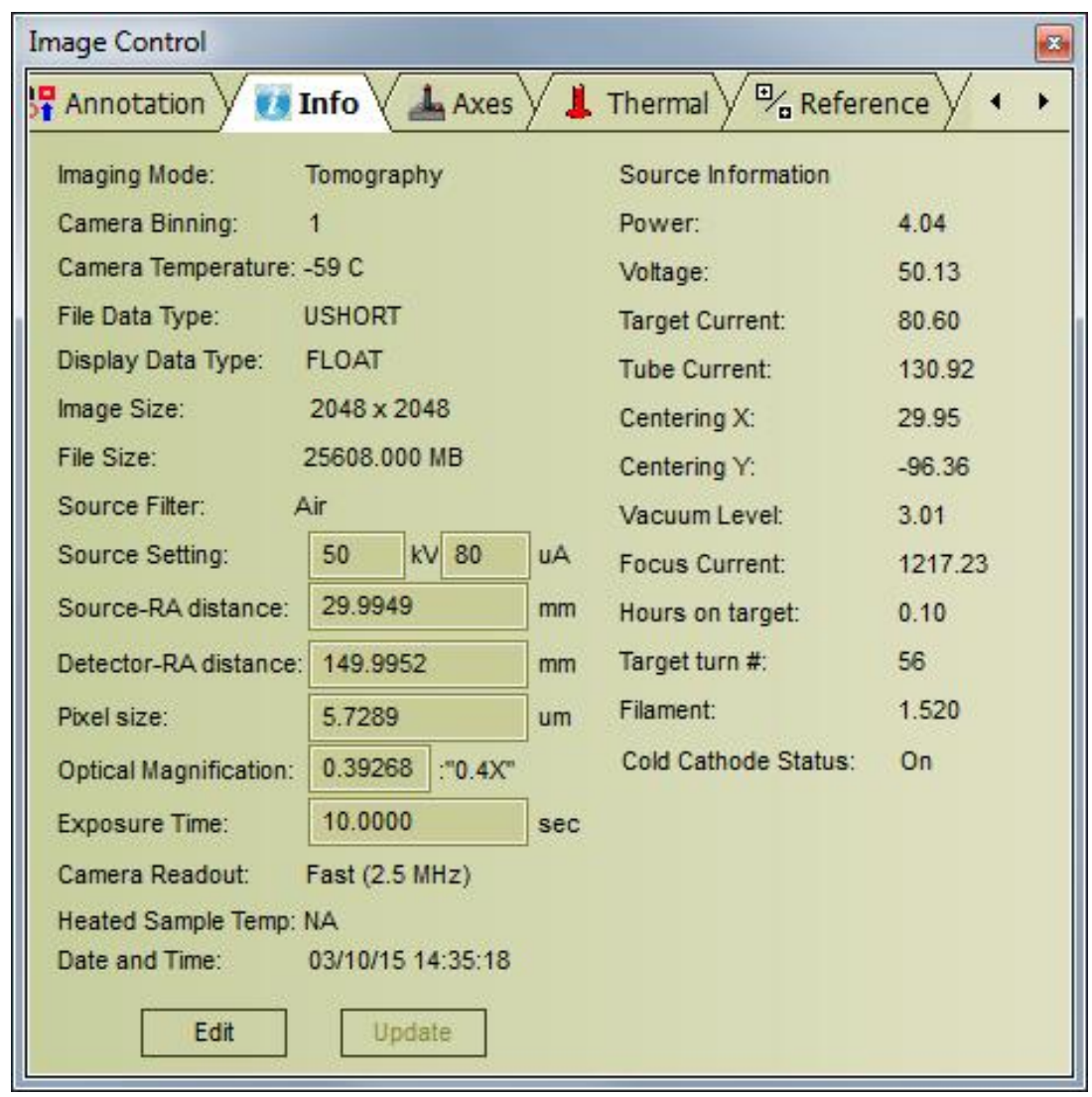

Figura 13: Caixa de diálogo do software Zeiss Image Control com os parâmetros utilizados para a condução das tomografias nas amostras de bambu.

Tabela 4: Configuração utilizada para a condução das tomografias. Em destaque os parâmetros editáveis.

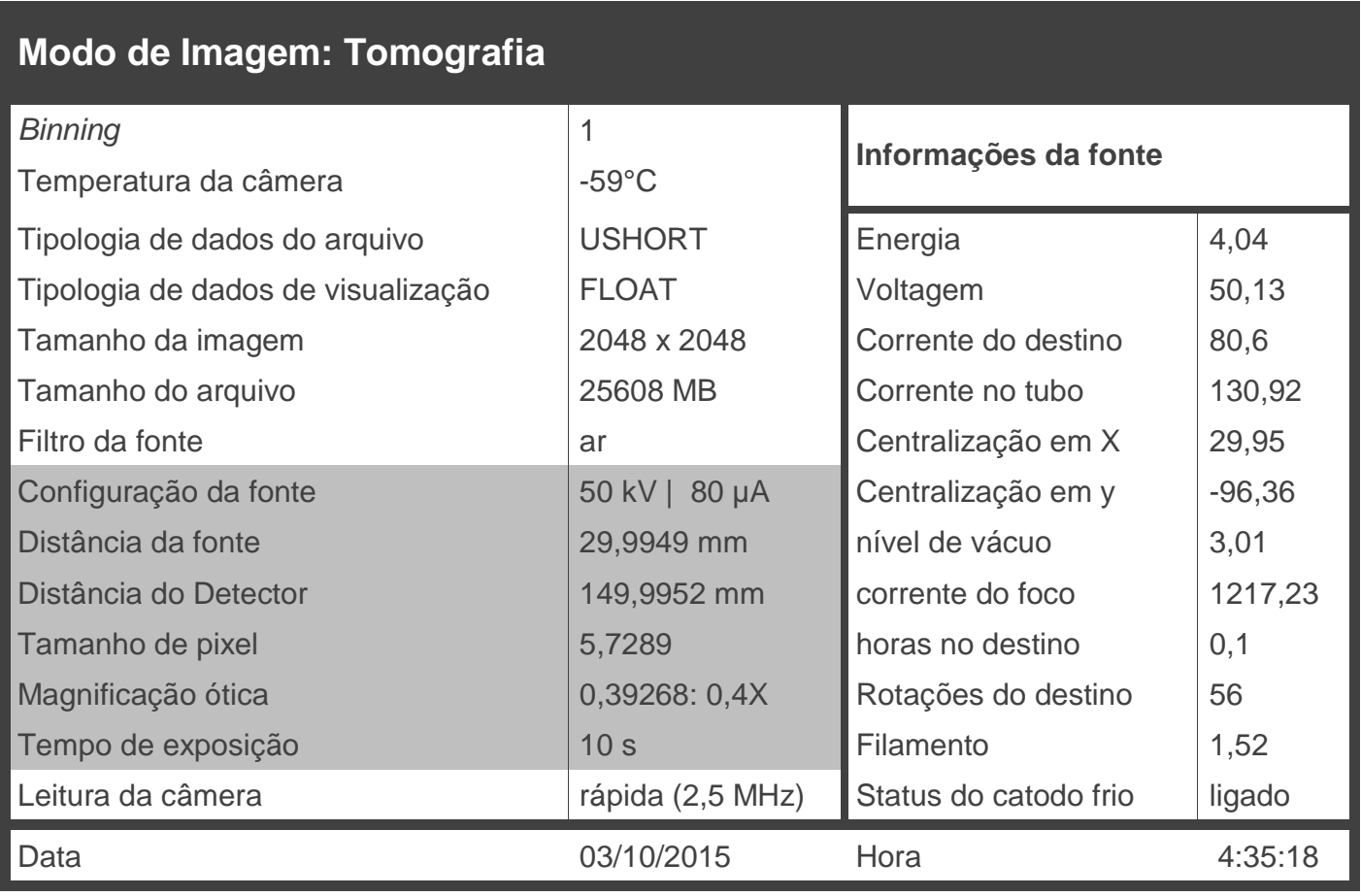


4.

As imagens obtidas foram processadas no CETEM, utilizando os softwares Image J Fiji, Irfan view, CTAn e ORS.

\subsection{Caracterização mesoestrutural via tomografia computadorizada}

No procedimento de tomografia os volumes podem ser obtidos automaticamente a partir do software de aquisição e processamento de imagens do próprio equipamento, com uma precisão bastante grande, e levando em consideração todas as anisotropias (visíveis) do material. Originalmente, a intenção era conseguir quantificar inclusive os vazios referentes ao parênquima, entretanto, o fator de aumento máximo, aliado à definição mínima aceitável (sem ruído na imagem), somente permitiram que os vazios na escala meso - vasos condutores de seiva - fossem visualizados e quantificados. Ainda assim pode-se ter um valor bastante preciso da porcentagem de fibras tanto nas regiões internodais (Figura 14), como nas regiões nodais (Figura 15), cuja aproximação por outros métodos é bastante difícil e imprecisa, por conta da orientação variada das fibras na região.

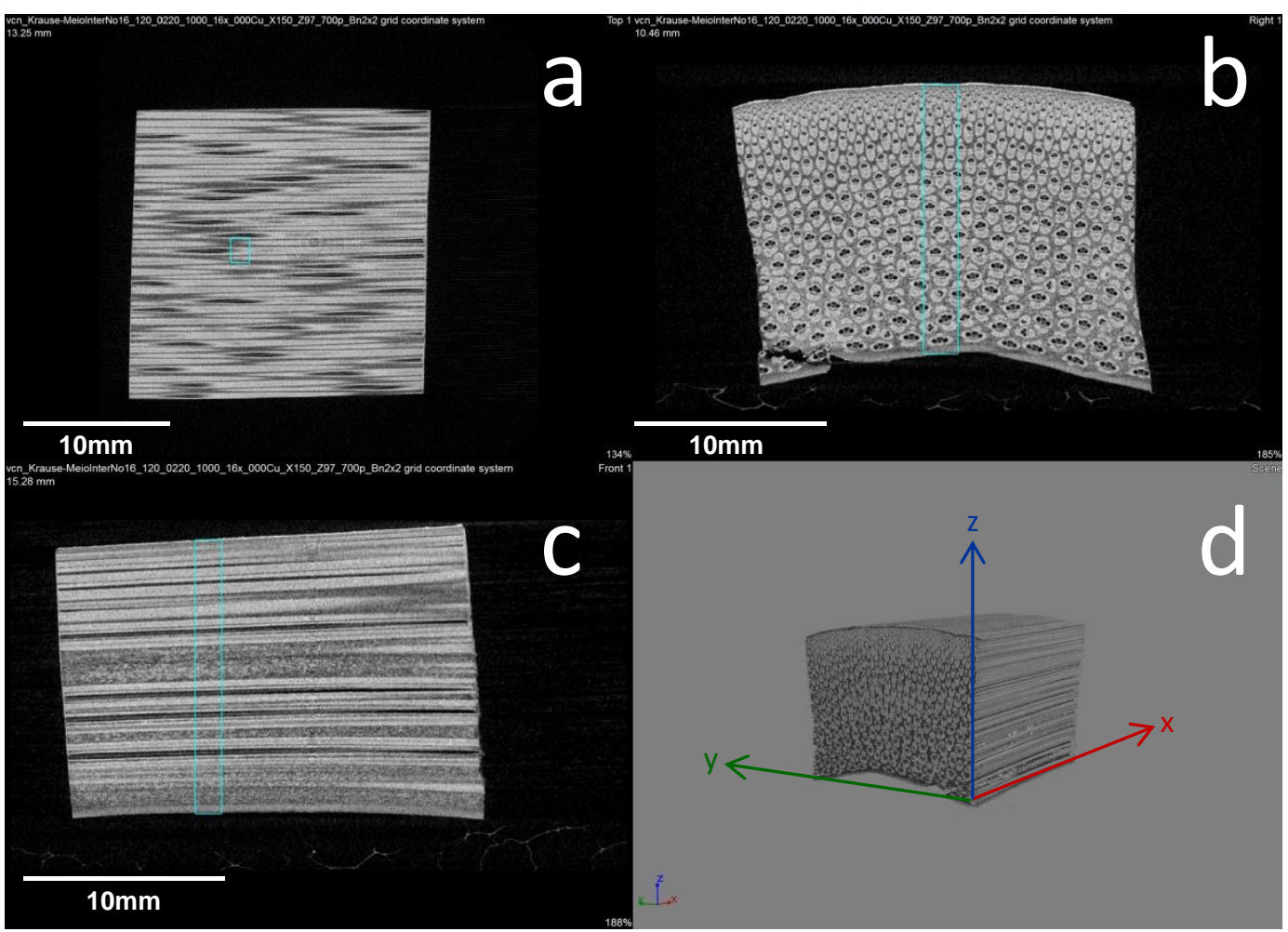

Figura 14: Vistas principais e cortes montados da tomografia da porção central de um colmo de Dendrocalamus giganteus em região internodal (16ำ internó) a saber: a) corte radial - plano xy; b) corte transversal - plano yz; c) corte radial - plano xz e d) perspectiva e referência de planos de corte. 
4.

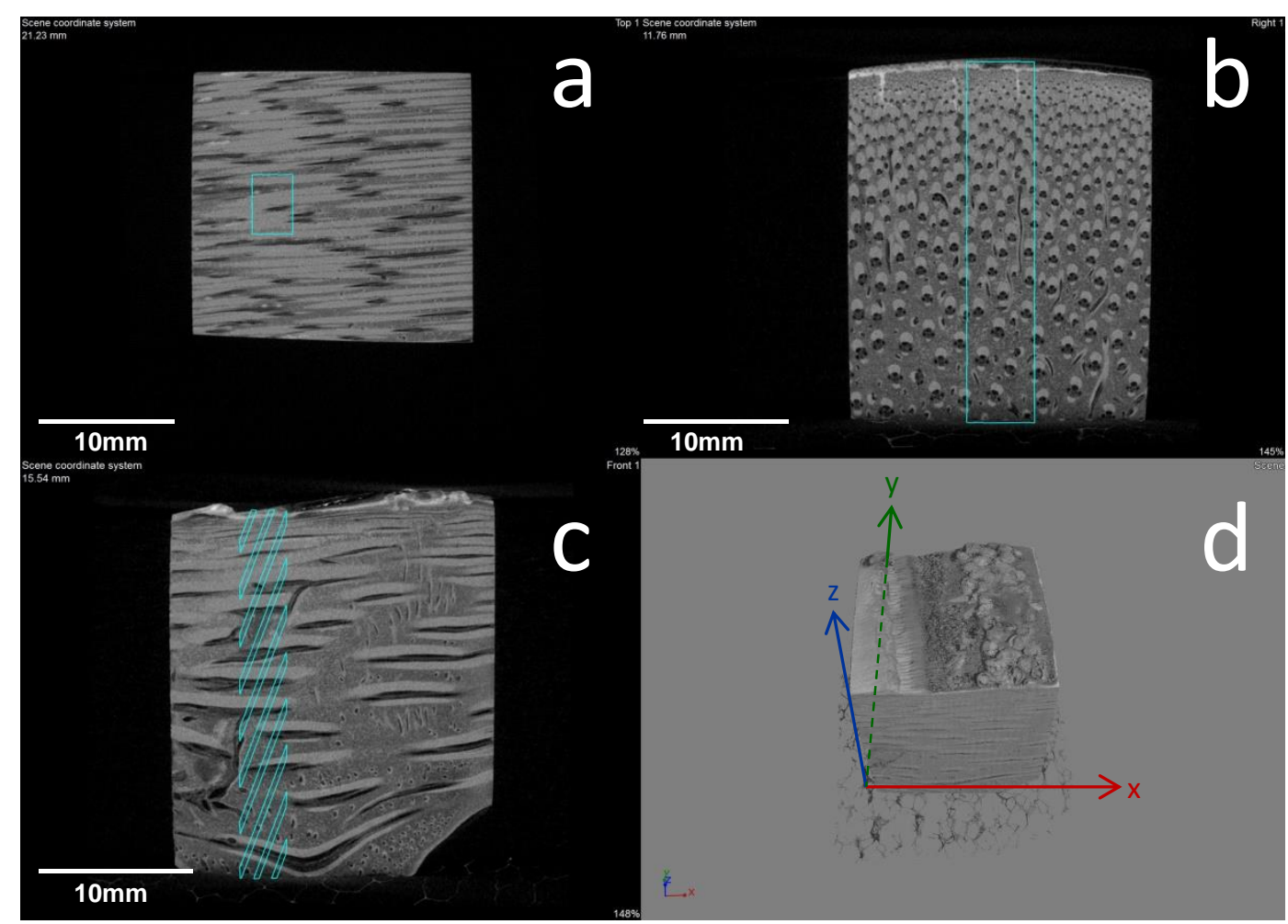

Figura 15: Vistas principais e cortes montados da tomografia da porção central de um colmo de Dendrocalamus giganteus em região nodal (16ํinternó) a saber: a) corte radial plano $x y$; b) corte transversal - plano yz; c) corte radial - plano $x z$ e d) perspectiva e referência de planos de corte.

Os dados quantitativos estão sintetizados na

Tabela 5 e os gráficos relacionando-os ao número do internó/nó correspondente são explicitados na Figura 16.

Tabela 5: Volumes e frações volumétricas mesoestruturais de vazios matriz e fibras de regiões internodais (IN) e nodais (N), provenientes de base (B), meio (M) e topo (T) de um colmo de Bambu Dendrocalamus giganteus.

\begin{tabular}{|l|l|l|l|}
\hline Corpo-de-prova & Fase (meso) & Volume $\left(\mathbf{m m}^{\mathbf{3}}\right)$ & Fração volumétrica (\%) \\
\hline INB & vazios & 9,87 & 6,80 \\
\hline \multirow{2}{*}{ internó 6 } & matriz & 77,45 & 53,34 \\
\cline { 2 - 4 } & fibras & 57,87 & 39,86 \\
\hline \multirow{2}{*}{ nó 6/7 } & vazios & 42,45 & 5,76 \\
\hline INM & matriz & 462,82 & 62,81 \\
\cline { 2 - 4 } & fibras & 231,59 & 31,43 \\
\hline internó 16 & vazios & 3,47 & 3,06 \\
\hline
\end{tabular}


4.

\begin{tabular}{|l|l|l|l|}
\hline & fibras & 66,35 & 58,49 \\
\hline NM & vazios & 28,55 & 6,13 \\
\hline \multirow{2}{*}{ nó $\mathbf{1 6 / 1 7}$} & matriz & 261,10 & 56,11 \\
\cline { 2 - 4 } & fibras & 175,72 & 37,76 \\
\hline INT & vazios & 1,00 & 3,20 \\
\hline \multirow{2}{*}{ internó 34 } & matriz & 10,63 & 33,85 \\
\cline { 2 - 4 } & fibras & 19,78 & 62,95 \\
\hline NT & vazios & 22,57 & 7,27 \\
\hline \multirow{2}{*}{ nó 33/34 } & matriz & 164,18 & 52,91 \\
\cline { 2 - 4 } & fibras & 123,54 & 39,81 \\
\hline
\end{tabular}
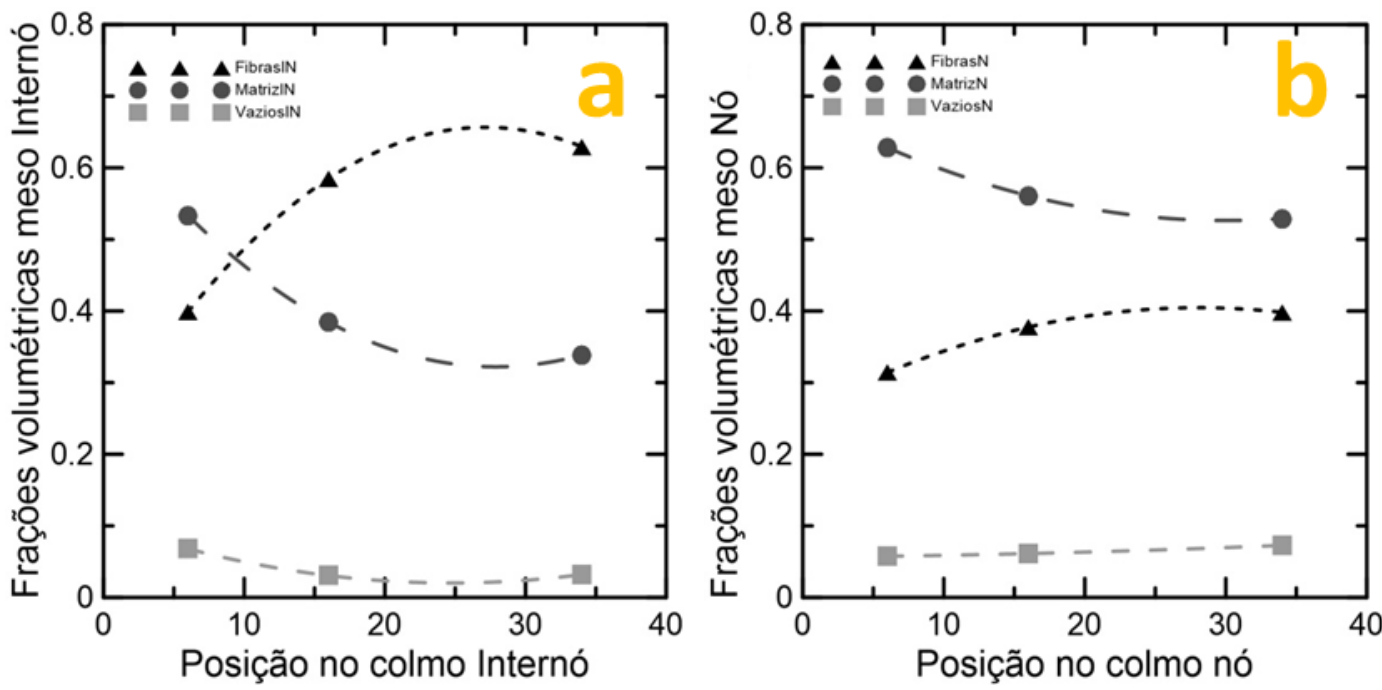

Figura 16: a) Gráfico relacionando frações volumétricas ao número do internó correspondente. b) Gráfico relacionando frações volumétricas ao número do nó correspondente.

Ao analisar as distribuições de frações volumétricas nessa escala não se percebe grande variação ou contribuição significativa nos teores de vazios, entretanto, para as regiões internodais apresenta leve queda, conforme a região do colmo é mais alta enquanto nas regiões nodais ocorre o oposto.

No que diz respeito às fases mais significativas em proporção, a variação no volume de fibras e matriz é praticamente inversamente proporcional. Nota-se que, tanto nas regiões nodais como nas internodais, a proporção de fibras cresce conforme a posição no colmo é mais alta, enquanto a fração volumétrica de matriz cai. A variação nas proporções é mais discreta nas regiões nodais. 
4.

\subsection{Caracterização microestrutural via microscopia ótica de luz transmitida e refletida e microscopia eletrônica de varredura}

Para melhor compreender a morfologia do material na escala micro e justificar as propostas de equações para a determinação de frações volumétricas propostas no próximo tópico, foram elaboradas e observadas preliminarmente amostras de regiões internodais de bambu Dendrocalamus giganteus para Microscopia Ótica de Luz Transmitida (MOLT), Microscopia Ótica de Luz Refletida (MOLR) e para Microscopia Eletrônica de Varredura (MEV).

Conforme descrito anteriormente no capítulo 3, as amostras de MOLT passam por um processo de ultramicrotomia, no qual uma lâmina de vidro ou diamante, popularmente denominada "faca", tem sua ponta repetidamente arrastada sobre a superfície de uma amostra diminuta, que por sua vez progressivamente vai sendo deslocada, de modo a obter cortes extremamente finos. Cortes de avaliação, como os ora apresentados, apresentam espessura entre 05 e $2 \mu \mathrm{m}$, mas cortes para uso em Microscopia Eletrônica de Transmissão podem variar entre 30 e $60 \mathrm{~nm}$. Na Figura 17, pode-se observar o sentido de corte do ultramicrótomo na seção transversal pela maneira como as células do parênquima (a matriz de células prismáticas ocas do bambu) se deformaram (no topo da imagem) e pela maneira como as fibras desagregaram o feixe (na base da imagem). 
4.

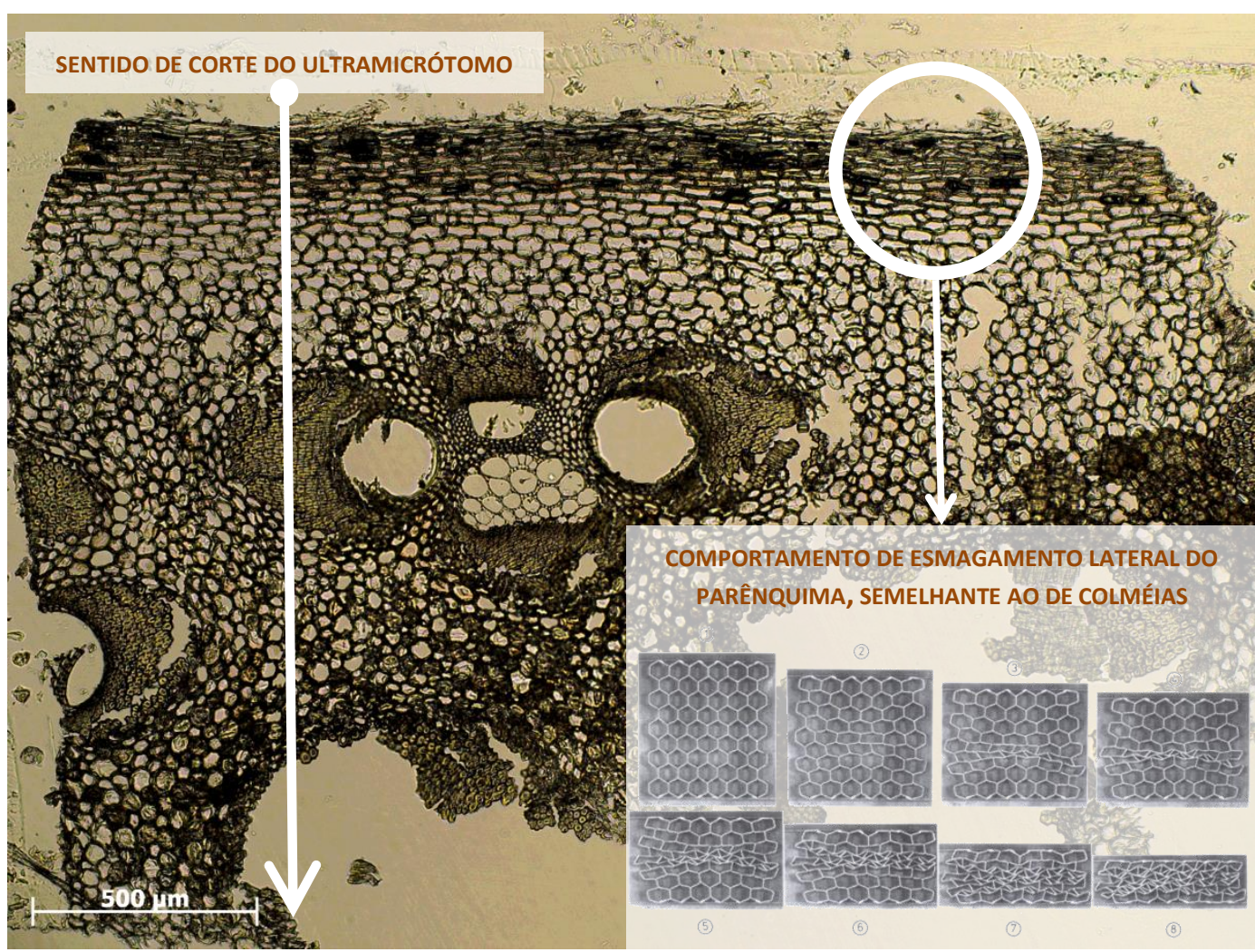

Figura 17: MOLT, com magnificação de 5X, de corte transversal de Dendrocalamus giganteus obtido a partir de ultramicrotomia e comportamento do parênquima sob compressão transversal [83].

A Figura 18, com maior magnificação, permite observar e definir as estruturas que compõem o bambu, bem como o alto teor de vazios em diferentes escalas. Vazios maiores podem ser observados nos vasos condutores de seiva, com diâmetro da ordem de dezenas a poucas centenas de micra. No parênquima, estrutura predominantemente formada de lignina que forma a matriz celular do compósito, observa-se a maior quantidade de vazios do material em formas poligonais com dimensões entre vértices variando entre micra e decamicra. No esclerênquima, tecido que forma os feixes de fibras que estruturam os vasos condutores, observa-se no trecho ampliado da figura a presença de vazios denominados lúmens, posicionados na porção central das fibras isoladas constituídas fundamentalmente de celulose com paredes externas lignificadas, com diâmetro da ordem de centenas de nanômetros a alguns micra. A ilustração destaca uma fibra técnica com a estratificação das camadas de fibrilas. Em cada camada as fibrilas possuem uma orientação diferente. 
4.

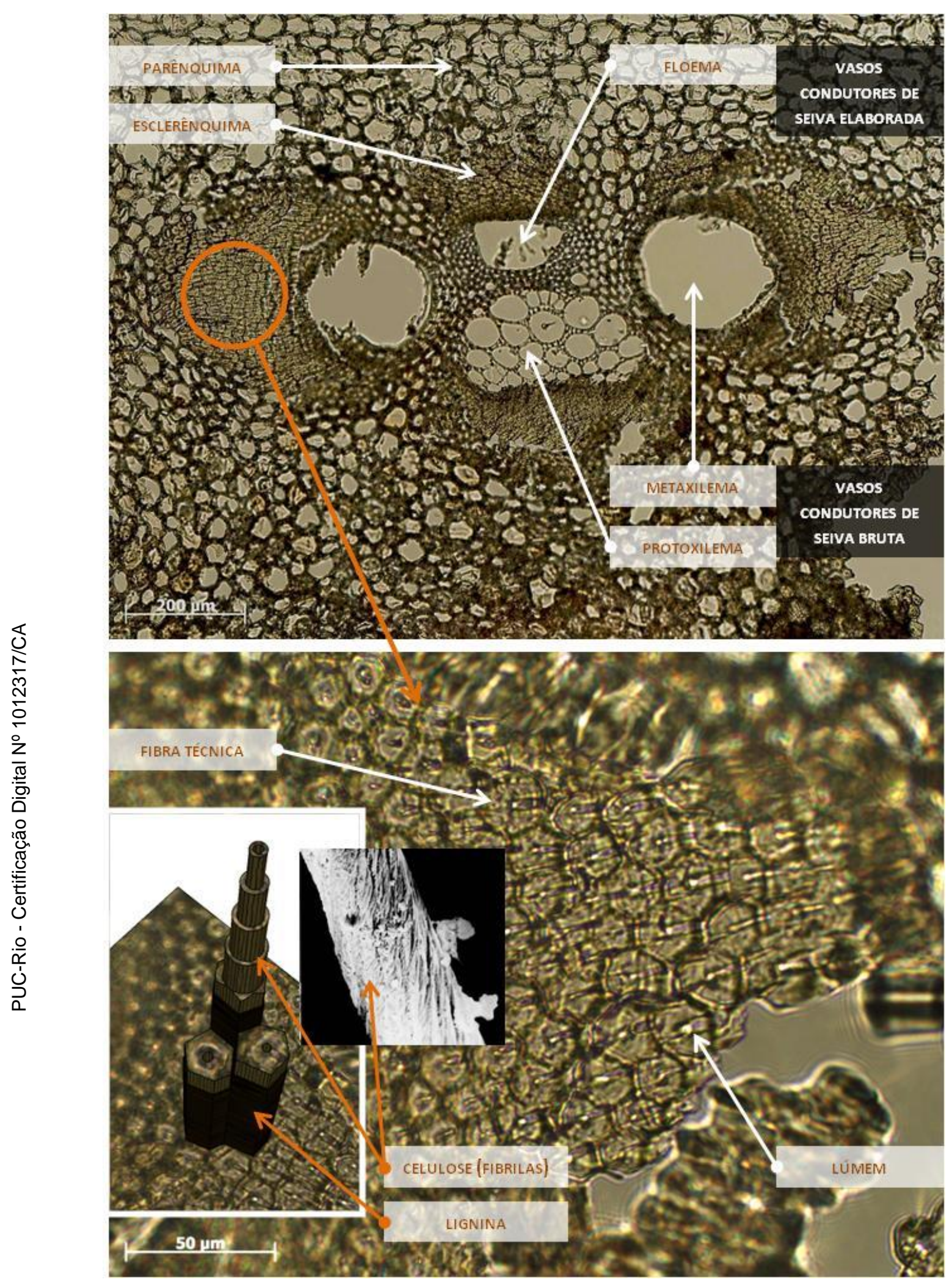

Figura 18: MOLT de corte transversal de Dendrocalamus giganteus com magnificação de 10X, detalhe de um dos feixes de fibras com magnificação de 50X, ilustração tridimensional de três fibras técnicas e da divisão das fibrilas em camadas e microestrutura de uma fibra técnica, exibindo as fibrilas [84]. 
4.

A partir de um corte longitudinal do bambu (Figura 19) também pode-se perceber a maneira como o parênquima se deforma quando submetido à ultramicrotomia, no ponto de contato com a faca à compressão, colapsando as paredes celulares prismáticas retangulares e à tração, rompendo-as, provavelmente quando a faca atinge a fibra (mais densa) esgarçando a matriz.

Percebe-se também a desagregação das fibras em um dos feixes, quando submetidas à tração transversal.

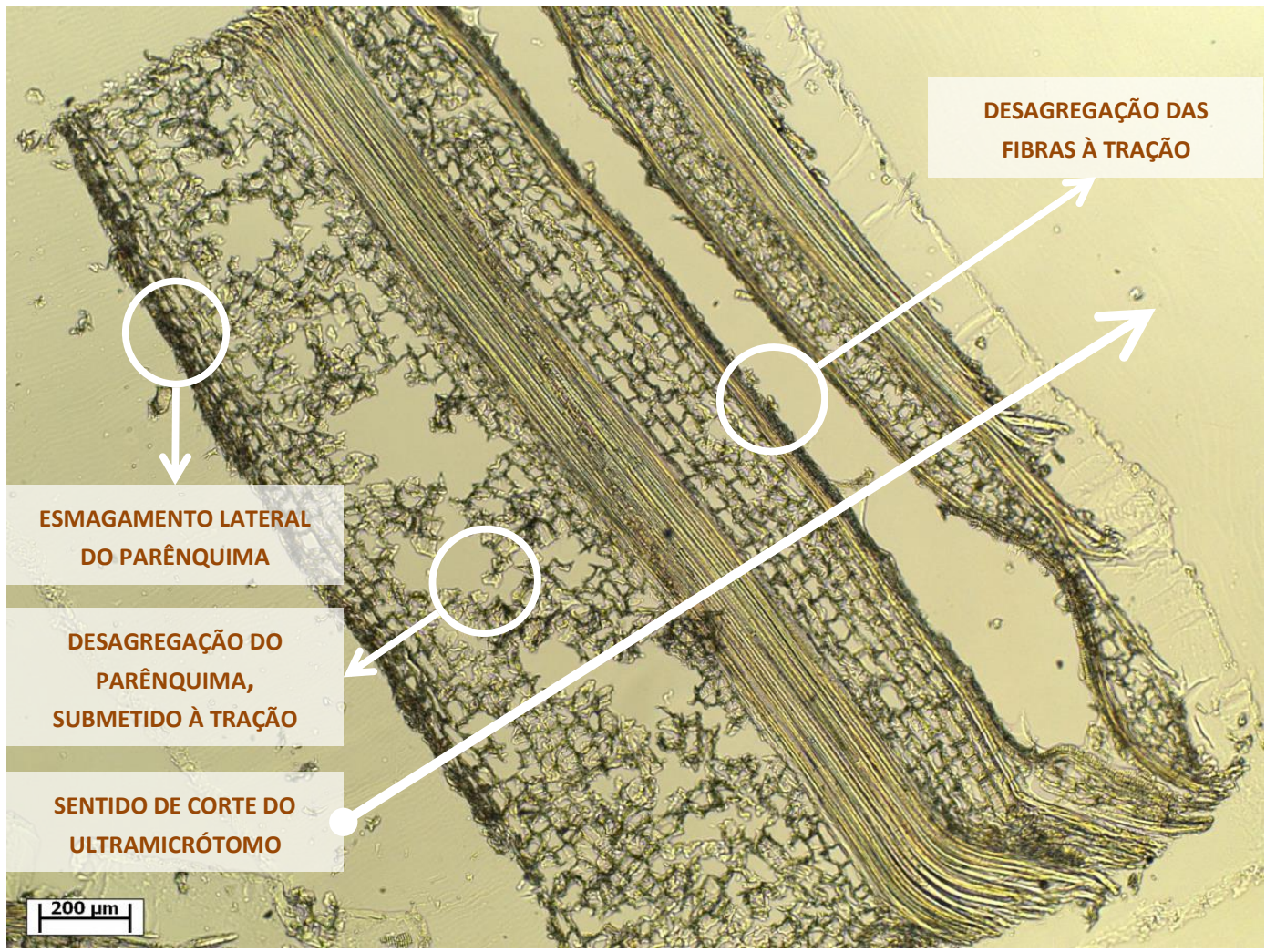

Figura 19: MOLT, com magnificação de 5X, de corte longitudinal de Dendrocalamus giganteus obtido a partir de ultramicrotomia e comportamento do parênquima sob compressão transversal.

$\mathrm{Na}$ Figura 20 observa-se o considerável alinhamento das fibras no esclerênquima e o parênquima estruturado longitudinalmente num padrão semelhante ao da argamassa de assentamento em uma parede de tijolos, longitudinalmente alinhadas, mas com emendas transversalmente desencontradas. No detalhe pode-se observar os microporos $(\varnothing<1 \mu \mathrm{m})$ nas paredes celulares do parênquima, que permitem a condução transversal de nutrientes. 
4.

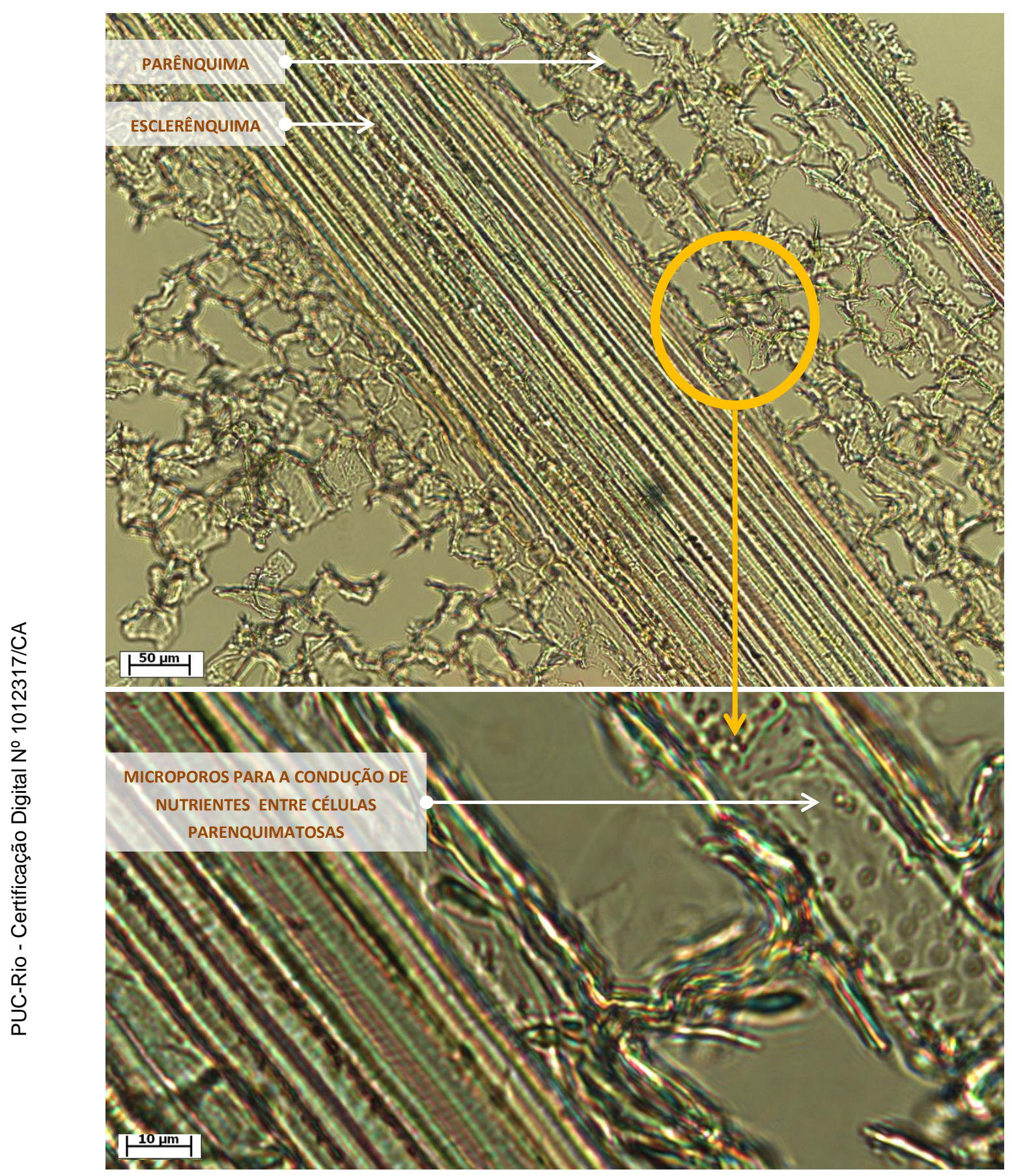

Figura 20: MOLT de corte longitudinal de Dendrocalamus giganteus com magnificação de 10X, detalhe de um dos feixes de fibras com magnificação de 50X.

Nas estereoscopias (Figura 21) e nas imagens de MOLR (Figura 22) e fica clara a dificuldade de obter preenchimento pleno dos vazios no bambu com a resina de embutimento, dada a presença de inclusões de substâncias orgânicas, inorgânicas e resíduos metabólicos tanto nos vasos condutores de seiva como nas células do parênquima. Ademais, considerando a dimensão dos microporos, 
4.

relatada anteriormente, a distribuição da resina pelo parênquima é ainda mais dificultada.

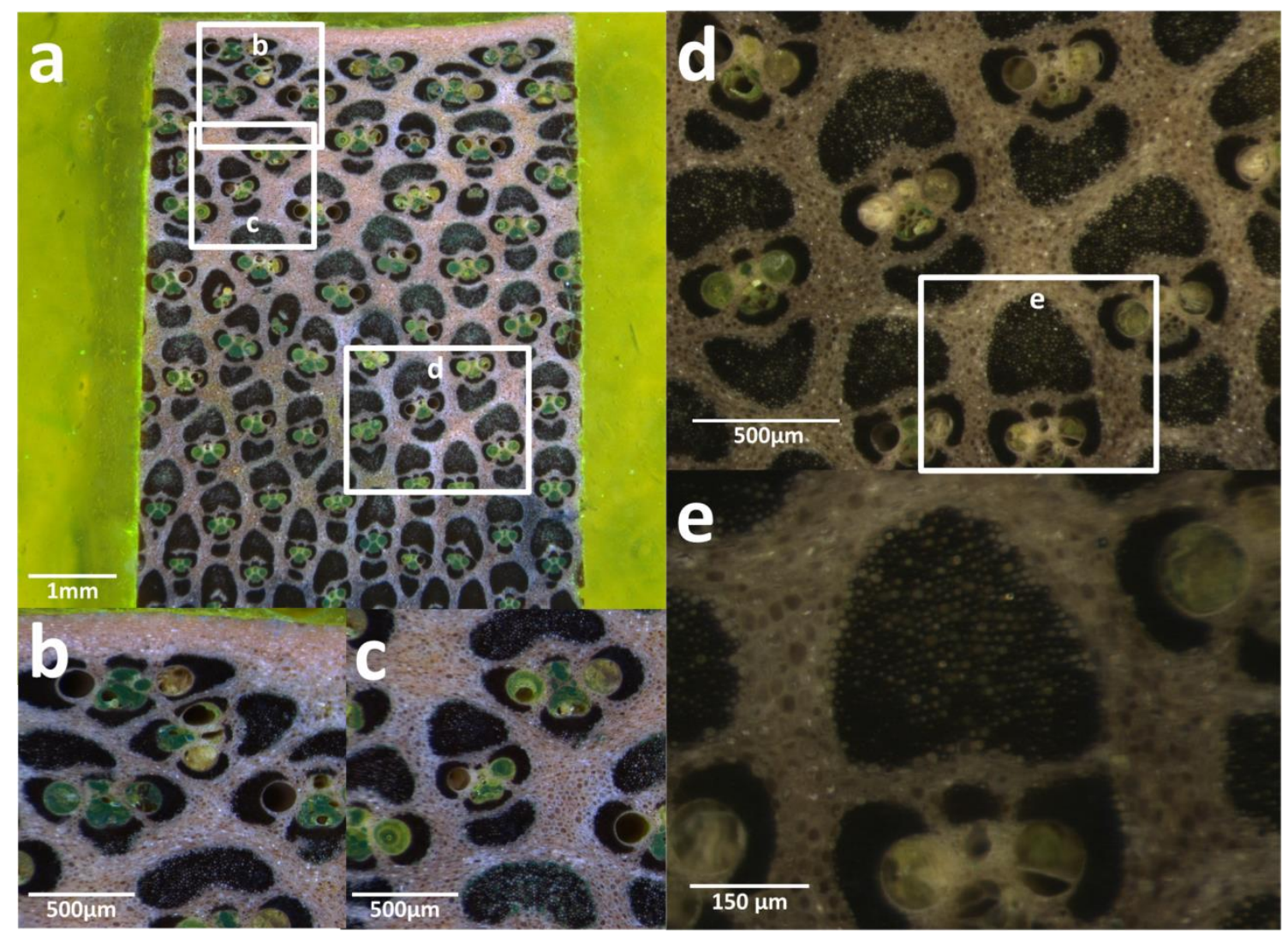

Figura 21: a) Estereoscopia com lente de 1x, porção apical de Dendrocalamus giganteus. b) Estereoscopia com lente de 5x da região mais interna da parede do colmo. c) Estereoscopia com lente de $5 x$ da regão medial interna da parede do colmo. d) Estereoscopia com lente de $5 x$ da região medial da parede do colmo. e) Detalhe em estereoscopia com lente de $10 x$, de um feixe de fibras na região medial da parede do colmo.

Dados qualitativos podem ser observados tanto a partir das estereoscopias como das MOLR. Verifica-se a variação no formato das fibras que são mais alargadas junto ao limite interno da parede do colmo (Figura 21b) e gradualmente se tornam mais esbeltas e compridas no sentido radial do colmo (Figura 21c e Figura 21d) em especial no que diz respeito às calotas adicionais de fibras junto ao Protoxilema e ao Floema. Nota-se ainda que as calotas adicionais são consideravelmente mais porosas que os feixes fibrosos anexos aos vasos (de um modo geral). Com o uso da fluorescência, diferentemente do esperado originalmente, a matriz não teve sua porosidade destacada (Figura $22 b$ e Figura 22d), apresentando o parênquima uma luminosidade difusa que evidencia alguma absorção de polímero corado. 
4.

Nas MOLR verifica-se uma ferramenta bastante interessante para a avaliação de integridade do material, quando utilizada a técnica de fluorescência. A referida técnica ressalta os pontos ocupados pelo pigmento reagente à luz num comprimento de onda específico, o que mostrou-se um instrumento capaz de evidenciar trincas nos feixes de fibras (Figura 22d).

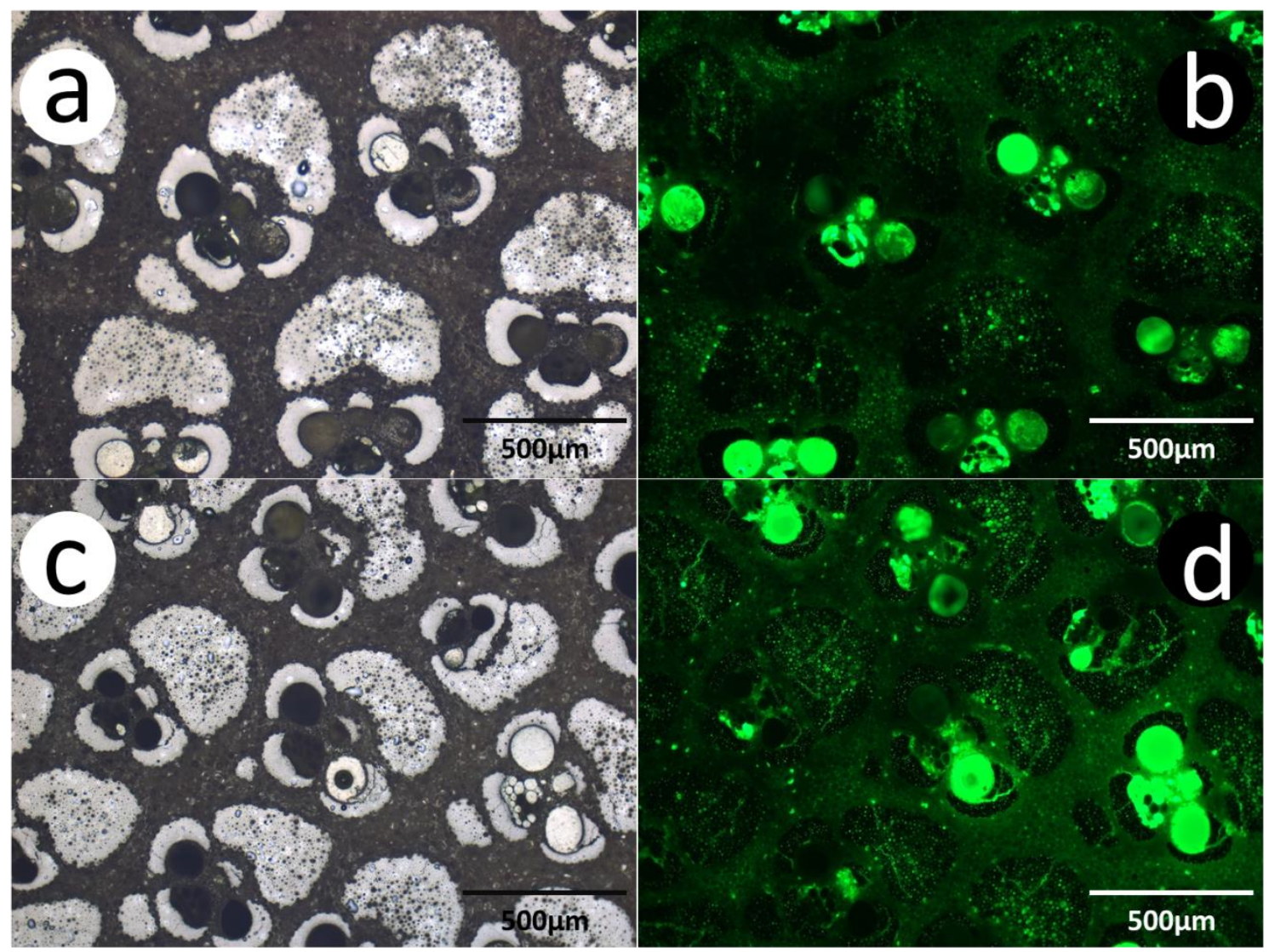

Figura 22: MOLR com aumento de $5 x$ obtida a partir da região apical, em porção central da parede em campo claro (a e c) e fluorescência (b e d).

As micrografias obtidas pelo MEV, permitem visualizar com clareza a porosidade do parênquima, mas requereriam grande trabalho e tempo para montar grandes mosaicos de tal maneira que fosse possível obter uma imagem com toda a espessura da amostra, de modo a permitir uma avaliação quantitativa da distribuição dos vazios. Possibilitam ainda obter imagens com bom contraste, que permitem a observação de outras questões morfológicas do material. A Figura 23a exibe o padrão mais concentrado de fibras da porção externa da parede do colmo de bambu, próximo ao córtex. Percebe-se que os feixes de fibras possuem uma forma alongada, alinhada com o eixo radial do material. Já na Figura 23b, observa-se fibras de uma porção mais interna da 
4.

parede do colmo. Percebe-se que a distribuição é mais esparsa e que o formato do esclerênquima é mais dividido e bastante menos alongado, de forma similar às observações feitas por estereoscopia. Comparando-se os vasos condutores nas diferentes porções da parede do colmo percebe-se uma diferença considerável de tamanho, sendo os mais externos (diâmetro da ordem de dezenas de micra) consideravelmente menores que os mais internos (diâmetro da ordem de poucas centenas de micra).

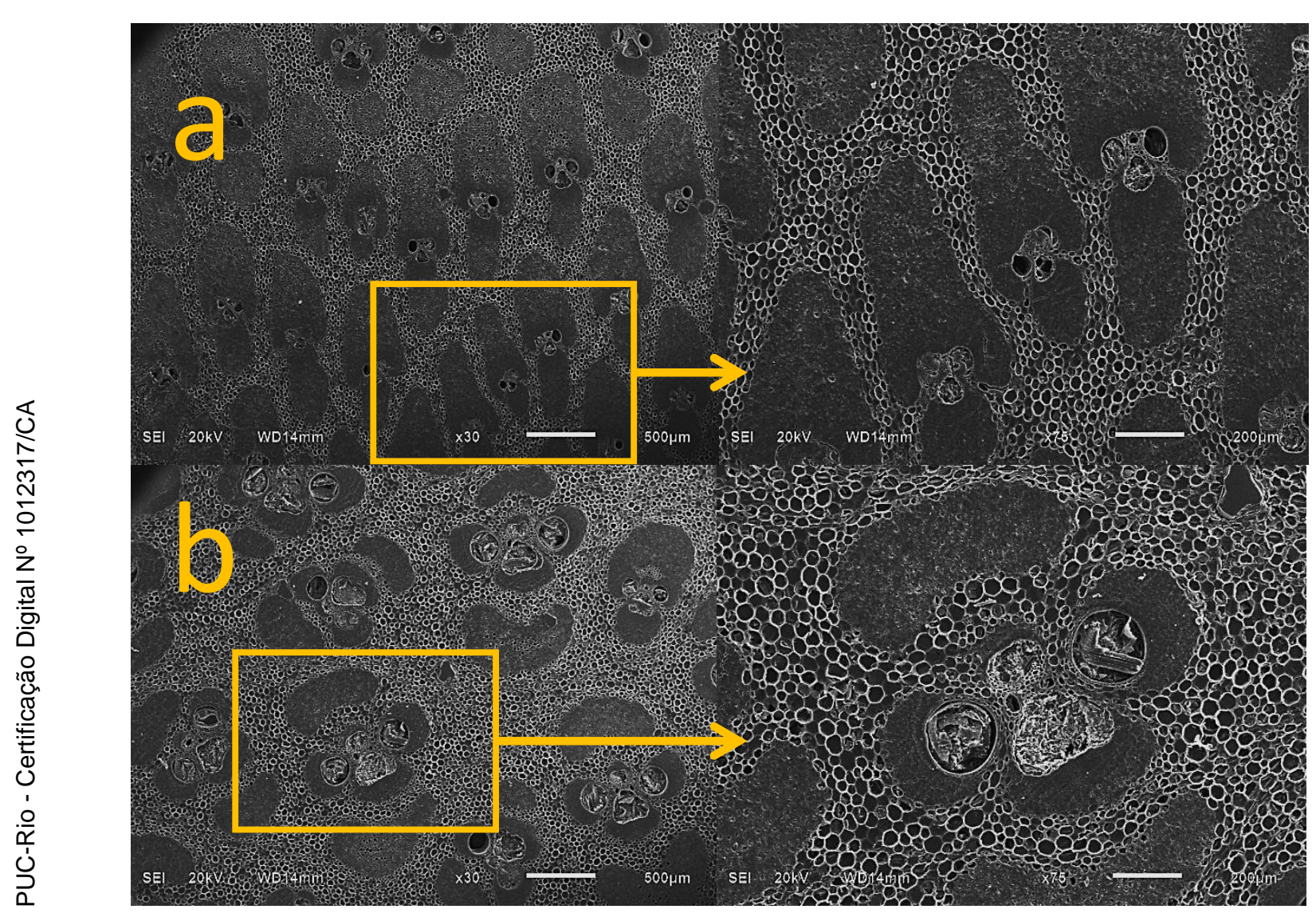

Figura 23: MEVs da região medial da porção basal do bambu com magnificação de 30X obtidas a partir: a) da metade externa e b) da metade interna da parede do colmo e respectivos detalhes dos feixes de fibras com magnificação de 75X.

Reitera-se nestas imagens a dificuldade em preservar os vazios, fundamentalmente os mesovazios, relacionados aos vasos condutores, quando é necessário preparar amostras, conforme evidenciado anteriormente na análise das amostras em MOLR e estereoscopia. 
4.

\subsection{Caracterização microestrutural quantitativa, por meio de microtomografias computadorizadas}

As microtomografias (Figura 24) permitem boa visualização tanto dos vazios do parênquima, como dos relativos aos feixes vasculares, sem qualquer problema de inclusões orgânicas ou resíduos metabólicos, permitindo quantificálos. Pode-se observar as inclusões inorgânicas, presentes principalmente nas amostras provenientes da região apical do colmo (Figura 24 - TE e TI). Nestes casos uma verificação adicional por difração de raios-x, pode determinar a composição das inclusões, permitindo avaliar, por exemplo, a sua importância no que diz respeito às propriedades mecânicas do material.

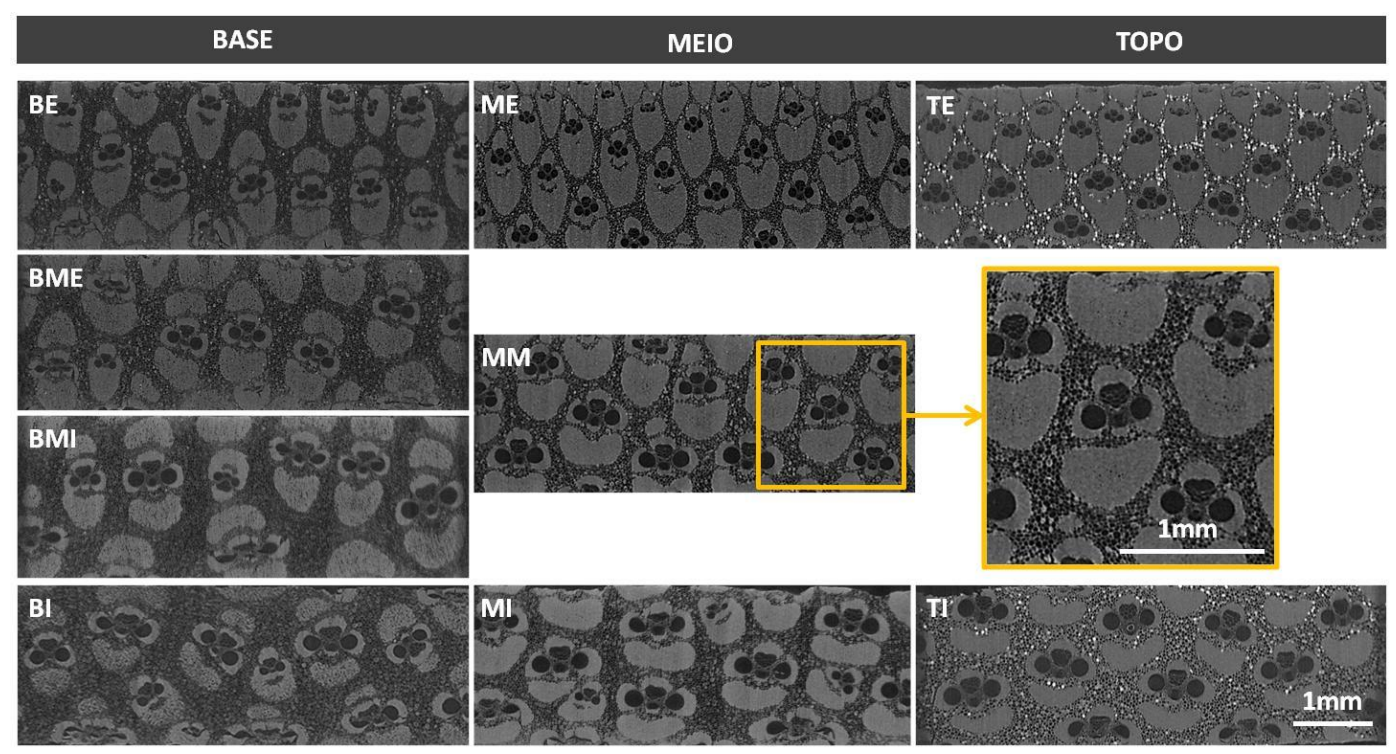

Figura 24: Cortes provenientes das 9 amostras de bambu Dendrocalamus giganteus submetidas a tomografia computadorizada, referentes às suas diferentes posições na altura do colmo e na espessura da sua parede e detalhe ampliado da resolução para visualização dos vazios do parênquima.

A imagens de meio e topo passaram por um processo de filtragem (em sequência, expansão de contraste, non local means, equalização de histograma, e sharpen) capaz de corrigir os ruídos e variações de brilho observadas em cada conjunto de imagens. A rotina básica é relativamente robusta, requerendo pequenas variações de uma amostra para outra, o que em um conjunto relativamente pequeno de amostras não incorre em qualquer empecilho.

Entretanto, nas amostras de base, nas quais o esclerênquima é muito poroso, a rotina não funciona. Além disso, as imagens apresentavam ruídos e distorções excessivas e não puderam ser analisadas. 
4.

Os aspectos quantitativos observados estão consolidados na Tabela 6.

Tabela 6: Parâmetros de correlação entre micra, pixels e voxels e frações volumétricas dos constituintes obtidas em porcentagem.

\begin{tabular}{|c|c|c|c|c|c|}
\hline amostras & MI & MM & ME & TI & TE \\
\hline Escala ( $\mu \mathrm{m} /$ pixel) & 5,438 & 5,438 & 5,639 & 5,440 & 5,512 \\
\hline Escala ( $\mu \mathrm{m} 3 /$ voxel) & 160,8 & 160,8 & 179,3 & 161,0 & 167,5 \\
\hline \multicolumn{6}{|l|}{$\begin{array}{c}\text { Microtomografias } \\
\text { segmentadas }\end{array}$} \\
\hline Esclerênquima (\%) & 37,66 & 45,44 & 54,69 & 27,54 & 54,11 \\
\hline Parênquima (\%) & 23,83 & 14,68 & 17,61 & 27,36 & 13,43 \\
\hline Poros no Parênquima (\%) & 29,27 & 29,47 & 21,76 & 33,65 & 22,55 \\
\hline Vasos (\%) & 9,23 & 10,40 & 5,94 & 11,45 & 9,91 \\
\hline$\Sigma$ vazios (\%) & 38,50 & 39,87 & 27,70 & 45,10 & 32,47 \\
\hline
\end{tabular}

\subsection{Outras possibilidades para a determinação de frações volumétricas}

Para a determinação da fração volumétrica total de cada constituinte estrutural da amostra, na falta de um equipamento de tomografia de alta resolução e poder de magnificação, é possível utilizar mosaicos obtidos a partir dos seus cortes transversal e longitudinal. Tal abordagem pode, entretanto ser excessivamente trabahosa e requerer alta capacidade computacional e técnica para a elaboração, montagem e processamento dos mosaicos, incorrendo em forte possibilidade de inviabilidade.

Ná análise das imagens, uma formulação diferente deverá ser aplicada para cada constituinte, considerando os dados obtidos a partir do seu processamento digital e de considerações específicas.

As mesmas formulações servem para definir as frações volumétricas distintas dos constituintes de cada camada transversal ao eixo radial do colmo, seja por meio de seccionamento e segmentação provenientes de processamento digital de imagens (Figura 25a), seja por meio do processamento físico e obtenção de lâminas sequenciais (Figura 25b). 
4.
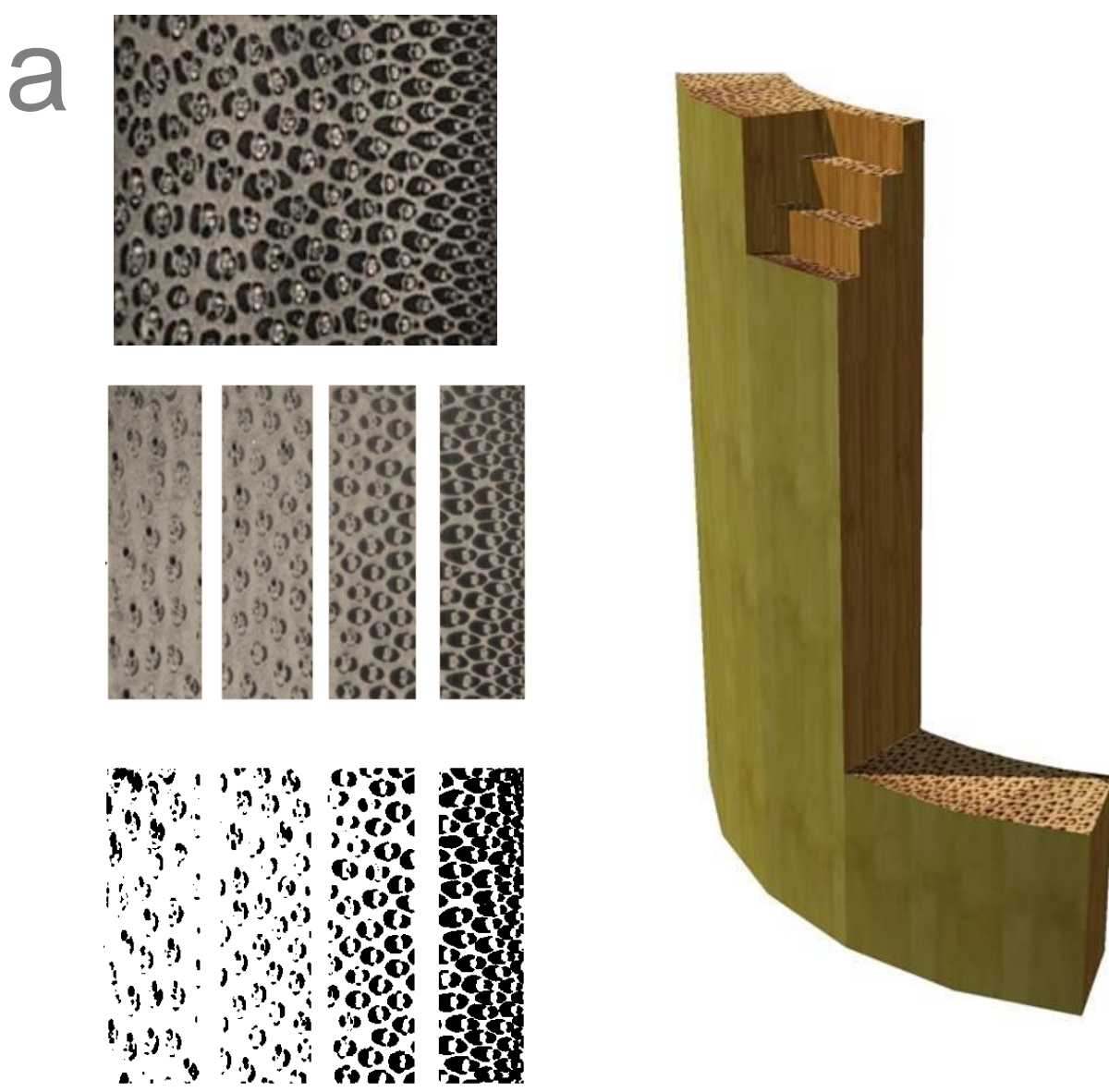

Figura 25: a) Seccionamento e segmentação (meso) por processamento digital de imagens e b) esquema de seccionamento sequencial de camadas transversais ao eixo radial do colmo.

Por processamento digital de imagens a definição das funções de variação dos constituintes tende a ser mais precisa, uma vez que não há qualquer perda relativa ao processamento físico das amostras. Assim pode-se definir a regra de misturas para o material considerando a sua funcionalidade graduada em relação à variação de todos os seus constituintes (equação 1), a ser aplicada às regiões basal, medial e apical do colmo.

$v_{f}(x)+v_{m}(x)+v_{v}(x)=1$

Eq. 1

$v_{f}(x)$ : função de variação de fração volumétrica de fibras em relação ao eixo radial $x$

$v_{m}(x)$ : função de variação de fração volumétrica de matriz em relação ao eixo radial $x$

$v_{v}(x)$ : função de variação de fração volumétrica de vazios em relação ao eixo radial $x$

A divisão física da seção do colmo em camadas sequenciais, por outro lado, pode ser associada a um procedimento experimental para a determinação das propriedades mecânicas de cada camada, notadamente conduzindo ensaios 
4.

de tração, compressão e cisalhamento dos corpos-de-prova, considerando o máximo possível de divisões por seção, repetindo-os para as regiões de base, meio e topo.

Nesse contexto é possível também traçar curvas com as frações volumétricas dos constituintes e, para cada região do colmo, determinar a função que rege sua variação ao longo da espessura da parede, combinando-as com os resultados dos ensaios mecânicos. Deste modo é possível correlacionar a variação das propriedades mecânicas à variação da morfologia do material.

\subsubsection{Fibras}

Adota-se o pressuposto de considerar os feixes de fibras contínuos. Embora não o sejam, o empacotamento meso e o comprimento de ancoragem nas descontinuidades entre as fibras proporcionam um comportamento global condizente com a consideração de fibras contínuas para materiais compósitos.

A partir do corte transversal obtém-se a área transversal de fibras $\left(S_{f T}\right)$, tomando-se o cuidado de excluir os vazios relativos aos lumens $\left(S_{v_{\text {lum }}}\right)$ e às falhas $\left(S_{v_{f a l}}\right)$. Obtém-se também a área transversal da amostra $\left(S_{a T}\right)$.

A partir do corte longitudinal obtém-se a altura total da amostra $\left(H_{a}\right)$.

A formulação para a fração volumétrica de fibras $\left(v_{f}\right)$ a partir dos dados obtidos com a microscopia é:

$v_{f}=\frac{V_{f}}{V_{a}}=\frac{S_{f T} * H_{a}}{S_{a T} * H_{a}} \therefore \frac{S_{f T}}{S_{a T}}$

Eq. 2

\subsubsection{Matriz}

Em bambus a matriz é formada pelo parênquima, constituinte extremamente poroso, como pode ser verificado na Figura 26, organizado por uma malha de prismas predominantemente hexagonais. 
4.

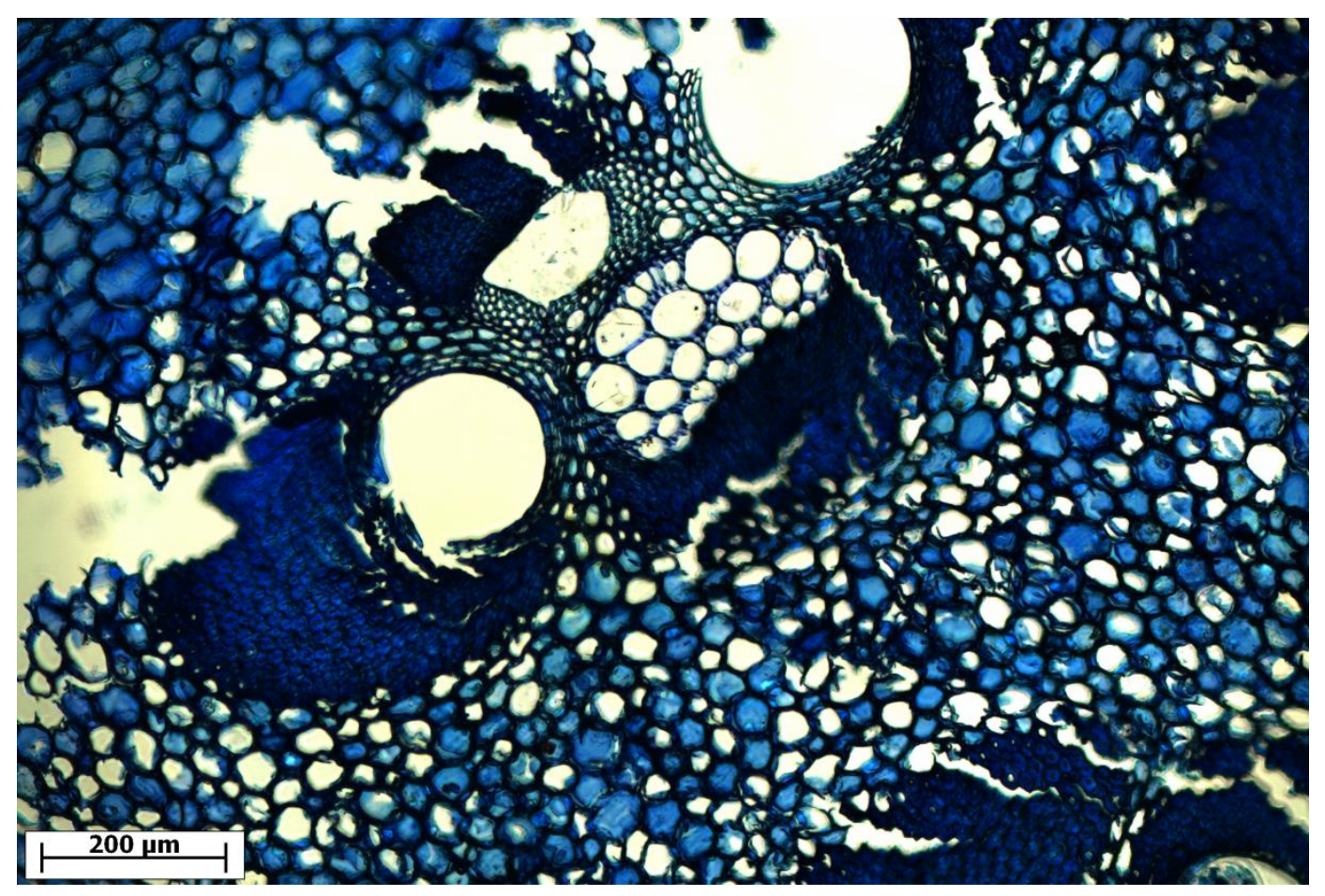

Figura 26: Micrografia ótica de luz transmitida com fator de aumento de 10x em uma amostra de bambu Dendrocalamus giganteus obtida por ultramicrotomia em seção transversal.

Para efeito de estimativa considera-se esta malha contínua em relação à altura da amostra, o que é bastante próximo da realidade, conforme pode ser observado na Figura 27. Nesta figura observa-se também a organização em forma de malha composta por retângulos com alturas variadas, verticalmente alinhados.

De modo similar ao pressuposto de continuidade adotado para o corte transversal da matriz, pode-se adotar como contínua a área longitudinal da mariz em relação à largura da amostra. Embora esta área seja claramente descontínua, estima-se que a distribuição aleatória de divisões horizontais $\left(S_{m D H}\right.$ em destaque amarelo na Figura 27) seja semelhante ao longo de toda a largura da amostra. 
4.

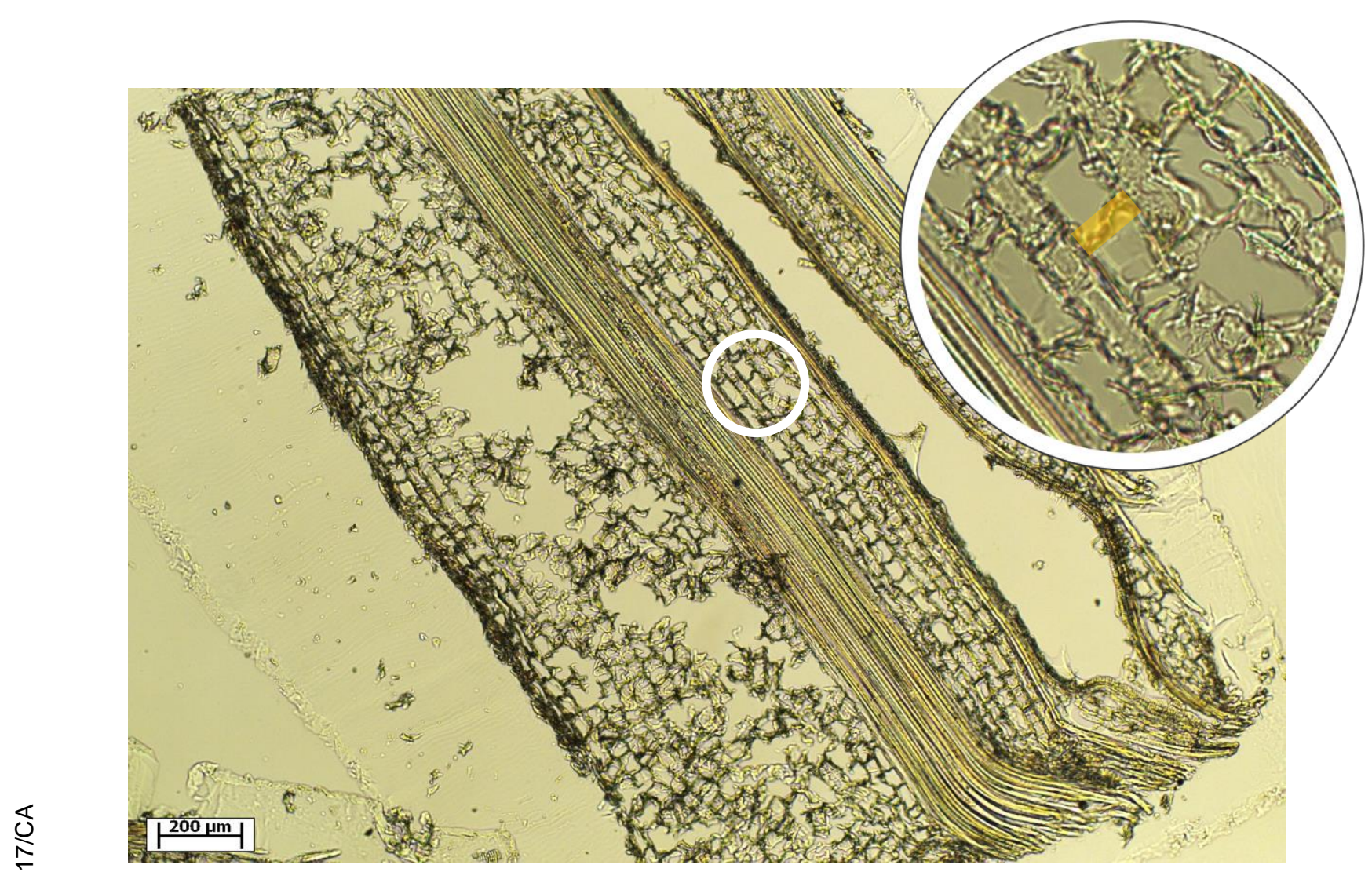

Figura 27: Micrografia ótica de luz transmitida com fator de magnificação de 10x em uma amostra de bambu Dendrocalamus giganteus obtida por ultramicrotomia em seção longitudinal. Detalhe ressaltado com fator de magnificação de 20x.

Considerando o exposto, a partir do corte transversal obtém-se a área transversal de matriz $\left(S_{m T}\right)$, a área transversal da amostra $\left(S_{a T}\right)$ e a largura da amostra $\left(L_{a}\right)$. A partir do corte longitudinal obtém-se a área longitudinal da matriz $\left(S_{m L}\right)$. Os vazios referentes à condução transversal de seiva no parênquima são insignificantes frente ao volume total de vazios e podem ser desconsiderados. A formulação para a obtenção da fração volumétrica de matriz $\left(v_{m}\right)$ a partir das premissas adotadas é:

$v_{m}=\frac{V_{m}}{V_{a}}=\frac{S_{m T} * S_{m L} / L_{a}}{C_{a} * L_{a} * H_{a}}=\frac{S_{m T} * S_{m L}}{S_{a L} * L_{a}^{2}}$

Eq. 3a

ou

$v_{m}=\frac{V_{m}}{V_{a}}=\frac{\left(S_{m T} * H_{a}\right)+\left(S_{m D H} * L_{a}\right)}{C_{a} * L_{a} * H_{a}}=\frac{S_{m T}}{S_{a T}}+\frac{S_{m D H}}{S_{a L}}$

Eq. $3 b$ 
4.

\subsubsection{Vazios}

Considerando a regra das misturas:

$V_{A}=V_{F}+V_{M}+V_{V} \therefore v_{f}+v_{m}+v_{v}=1$

Eq. 4

A formulação para a fração volumétrica de vazios $\left(v_{v}\right)$ é:

$v_{v}=1-\left(v_{f}+v_{m}\right) \therefore v_{v}=1-\left[\left(\frac{S_{m T} * S_{m L}}{S_{a L} * L_{a}^{2}}\right)+\left(\frac{S_{f T}}{S_{a T}}\right)\right]$

Eq. $5 a$

ou

$v_{v}=1-\left(\frac{S_{m T}}{S_{a T}}+\frac{S_{m D H}}{S_{a L}}+\frac{S_{f T}}{S_{a T}}\right)=\left(\frac{S_{m T}+S_{f T}}{S_{a T}}+\frac{S_{m D H}}{S_{a L}}\right)$

Eq. $5 b$

\subsection{Funções de variação de fibras, matriz e vazios}

A partir das quantificações das frações volumétricas, em porcentagem, de fibras, matriz e vazios provenientes do parênquima e dos vasos condutores, correlacionadas com a posição das diversas camadas da parede do bambu, nas diferentes porções do colmo, é possível traçar gráficos de funções polinomiais (Figura 28), que definam a variação decorrente da classificação funcional.

Dado que não foi possível estabelecer as referidas frações para a porção basal, conforme relatado anteriormente, a Tabela 7 explicita as funções referentes às porções medial e apical do colmo estudado. 
4.
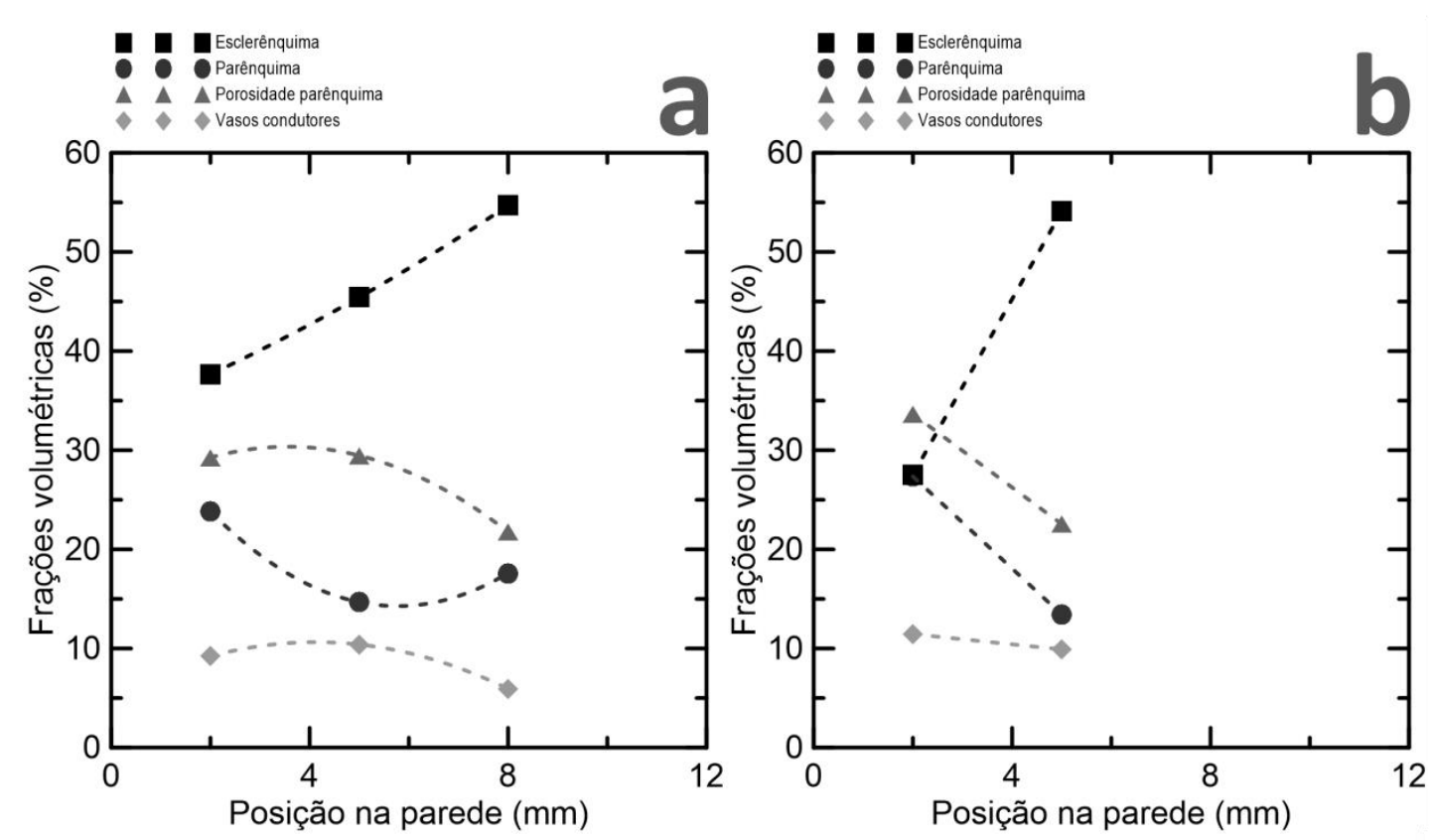

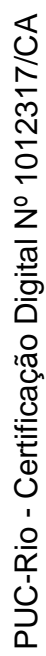
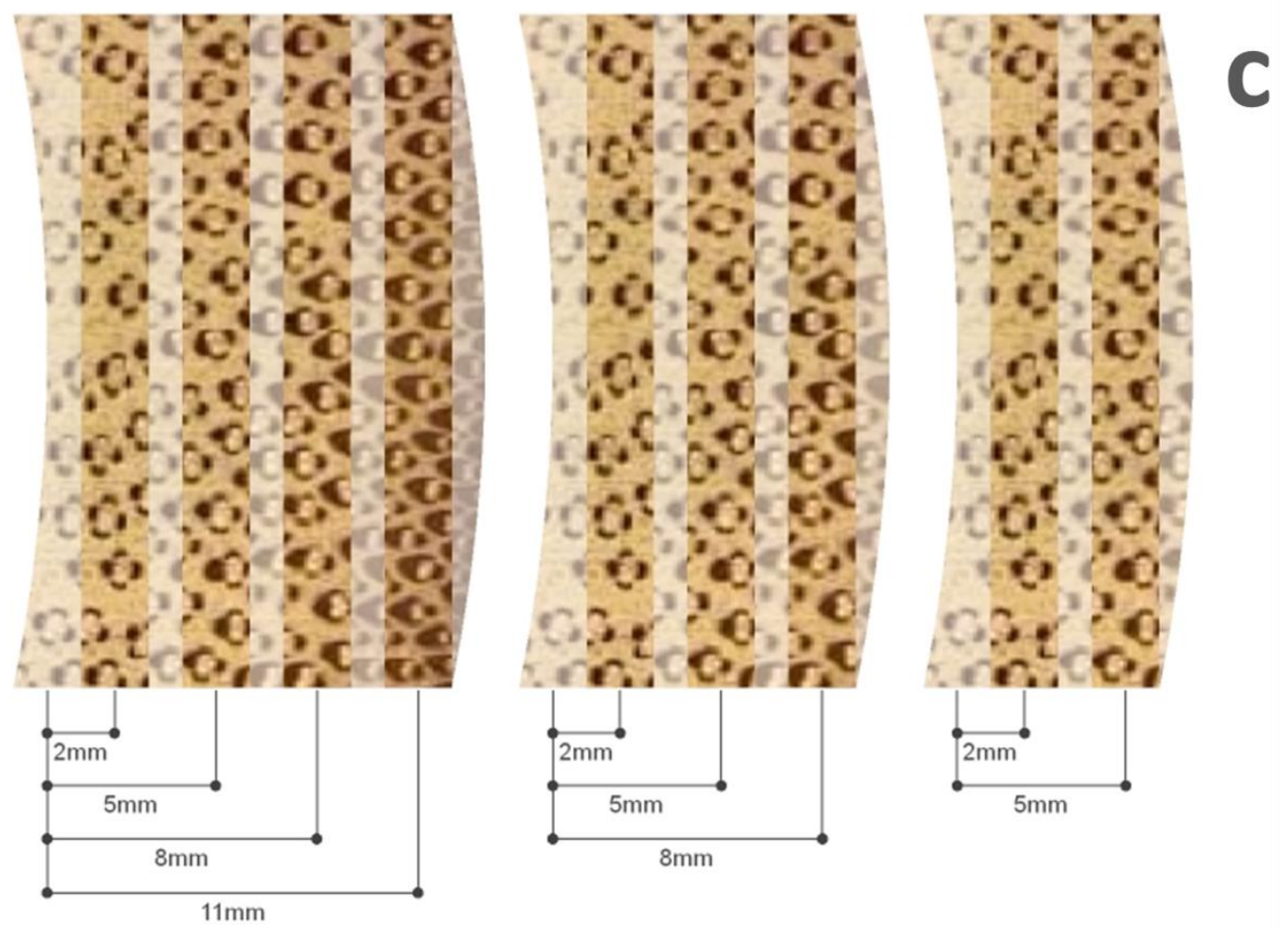

Figura 28: Gráficos de variação das frações volumétricas de fibras, matriz, porosidade da matriz e vasos para: a) uma amostra da porção medial de um colmo de Dendrocalamus giganteus; b) uma amostra da porção apical de um colmo da mesma espécie. c) esquemas de corte, explicitando a distância aproximada entre o limite interno da parede do colmo e o eixo da lâmina proveniente de cada camada (abcissa dos gráficos), para amostras de porções basais, mediais e apicais do colmo, respectivamente representadas da esquerda para a direita. 
4.

Tabela 7: Funções de variação radial de frações volumétricas dos constituintes e vazios de um colmo de bambu Dendrocalamus giganteus.

\begin{tabular}{|l|l|l|}
\hline \multicolumn{1}{c|}{$\begin{array}{c}\text { Porções do } \\
\text { colmo }\end{array}$} & Constituintes e vazios & \multicolumn{1}{c|}{$\begin{array}{c}\text { Funções de variação de fração } \\
\text { volumétrica }\end{array}$} \\
\hline \multirow{4}{*}{ Porção medial } & Esclerênquima & $e=0,0818 w^{2}+2,0195 w+33,298$ \\
\cline { 2 - 3 } & Parênquima & $p=0,6709 x^{2}-7,7458 x+36,64$ \\
\cline { 2 - 3 } & Poros do parênquima & $v_{p}=-0,4391 y^{2}+3,1388 y+24,753$ \\
\cline { 2 - 3 } & Vasos condutores & $v=-0,3136 z^{2}+2,5875 z+5,3087$ \\
\hline \multirow{3}{*}{ Porção apical } & Esclerênquima & $e=8,854 w+9,8362$ \\
\cline { 2 - 3 } & Parênquima & $p=-0,5128 x+12,477$ \\
\cline { 2 - 3 } & Poros do parênquima & $v_{p}=-3,6973 y+41,041$ \\
\cline { 2 - 3 } & Vasos condutores & $v=-4,6439 z+36,645$ \\
\hline
\end{tabular}




\section{5. \\ Ensaios mecânicos de controle}

\subsection{Introdução}

Este capítulo trata da descrição da metodologia de produção dos corposde-prova de bambu e da obtenção das suas relações constitutivas. Para tanto são realizados ensaios de tração, compressão, flexão e/ou cisalhamento em diversos corpos-de-prova distintos. Oportunamente serão ainda descritos os seus modos de falha e feitas observações sobre o comportamento apresentado.

Os ensaios mecânicos foram conduzidos no Laboratório de Estruturas da COPPE/UFRJ LABEST em uma Máquina Universal de Ensaios (MUE) eletromecânica Shimadzu AG-X com capacidade de carregamento de100 kN (Figura 29).

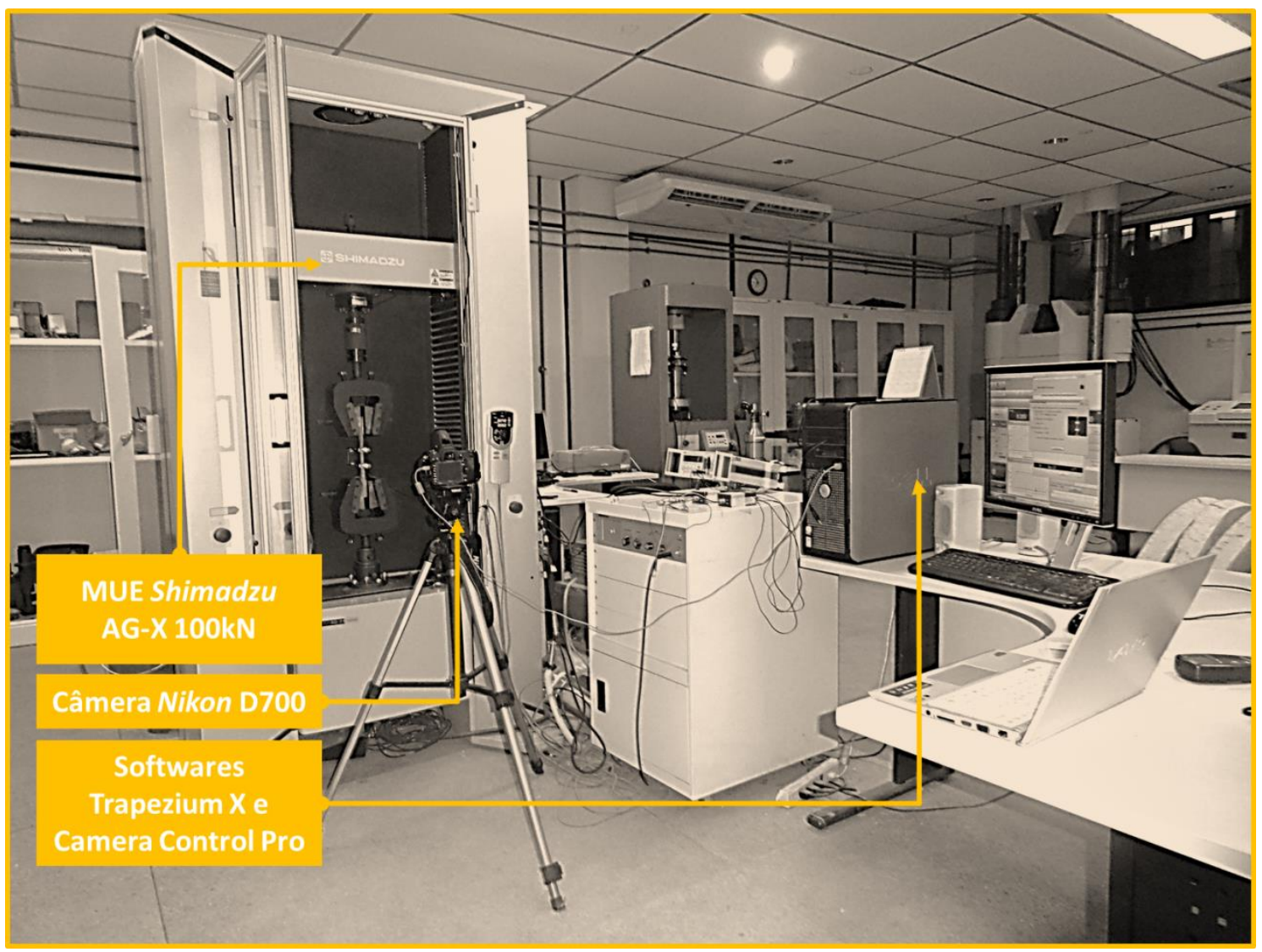

Figura 29: LABEST - Máquina universal de ensaios eletromecânica Shimadzu AG-X $100 \mathrm{kN}$ e esquema geral dos ensaios 
5.

A norma ISO 22157 [4], atualmente adotada para a determinação de propriedades físicas e mecânicas do bambu, foi elaborada fudamentalmente visando a aplicações que utilizem a seção completa do material, contemplando recomendações técnicas, bem como um conjunto de ensaios mecânicos. Entretanto, no que diz respeito ao material processado, notadamente à confecção de compósitos estruturais laminados, os dados relativos à seção cheia do colmo são de pouco interesse. Nesse ínterim, propõe-se um conjunto de procedimentos experimentais específico para a caracterização do bambu para uso em produtos processados, baseados fundamentalmente em normas ASTM para materiais compósitos.

O protocolo de ensaios de controle conduzidos inclui tração, compressão e cisalhamento, nas regiões basal, medial e apical do colmo, que dizem respeito a toda a espessura da parede do bambu e servem para avaliar a qualidade da matéria-prima.

\subsection{Ensaios de tração simples: Comparação entre corpos-de-prova ISO 22157 e ASTM D3039}

Aqui se realiza uma comparação entre os ensaios de tração simples atualmente utilizados, constantes na norma ISO 22157 [4] e uma proposição de adoção da norma ASTM D3039 [85].

Para a confecção dos corpos-de-prova de tração utilizou-se segmentos de base (internós 5 e 6), meio (internós (15 e 16) e topo (internós 33 e 34) de bambu da espécie Dendrocalamus giganteus provenientes da colheita de 2012, relatada no capítulo 3 (Figura 30 ). 
5.
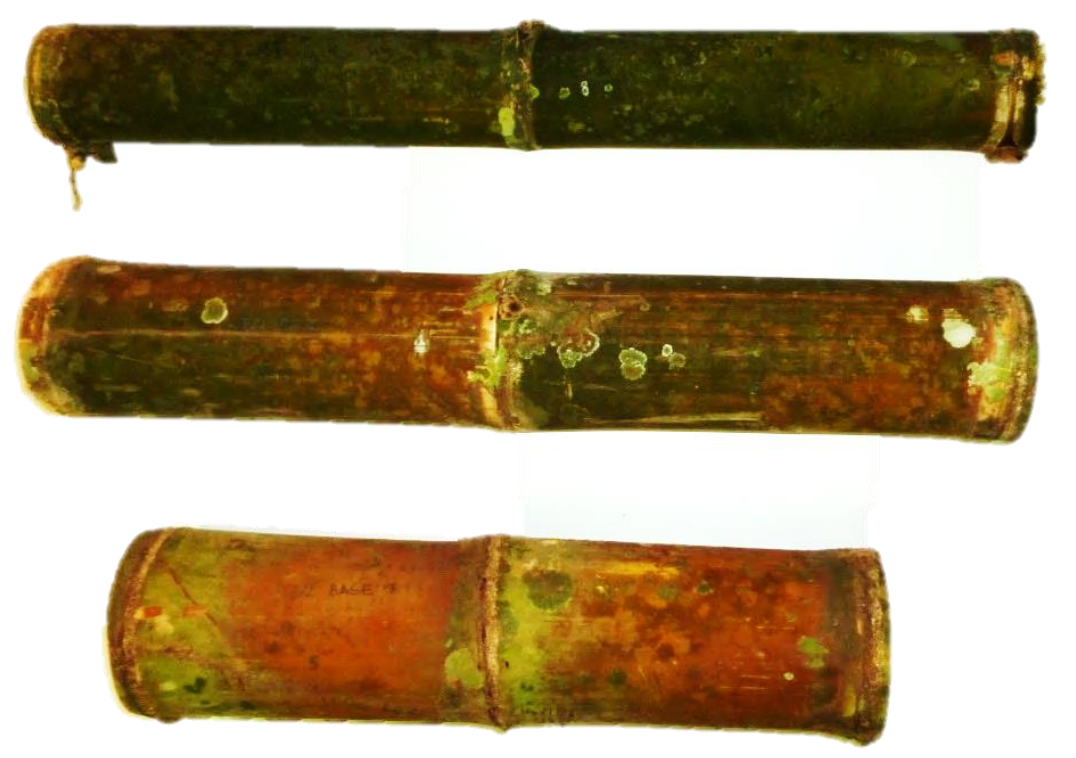

Figura 30: De baixo para cima: Segmentos de base (internós 6 e 7, nó 6), meio (internós 16 e 17, nó 16) e topo (internós 33 e 34, nó 33) de bambu utilizados para a confecção dos corpos-de-prova de tração simples - controle.

Dentre os ensaios descritos na ISO 22157 [4], somente o de tração simples não utiliza seção completa do material, recomendando três possibilidades de corpos-de-prova, dos quais o mais utilizado correntemente apresenta forma de osso (wedge shaped) com uma zona de estricção de $65 \mathrm{~mm}$ de comprimento, a espessura do colmo como largura e espessura não definida (adotou-se $4 \mathrm{~mm}$ ) (Figura 31). São utilizadas placas de alumínio ou madeira na região das garras para melhor distribuir os esforços evitando esmagamento local. 
5.

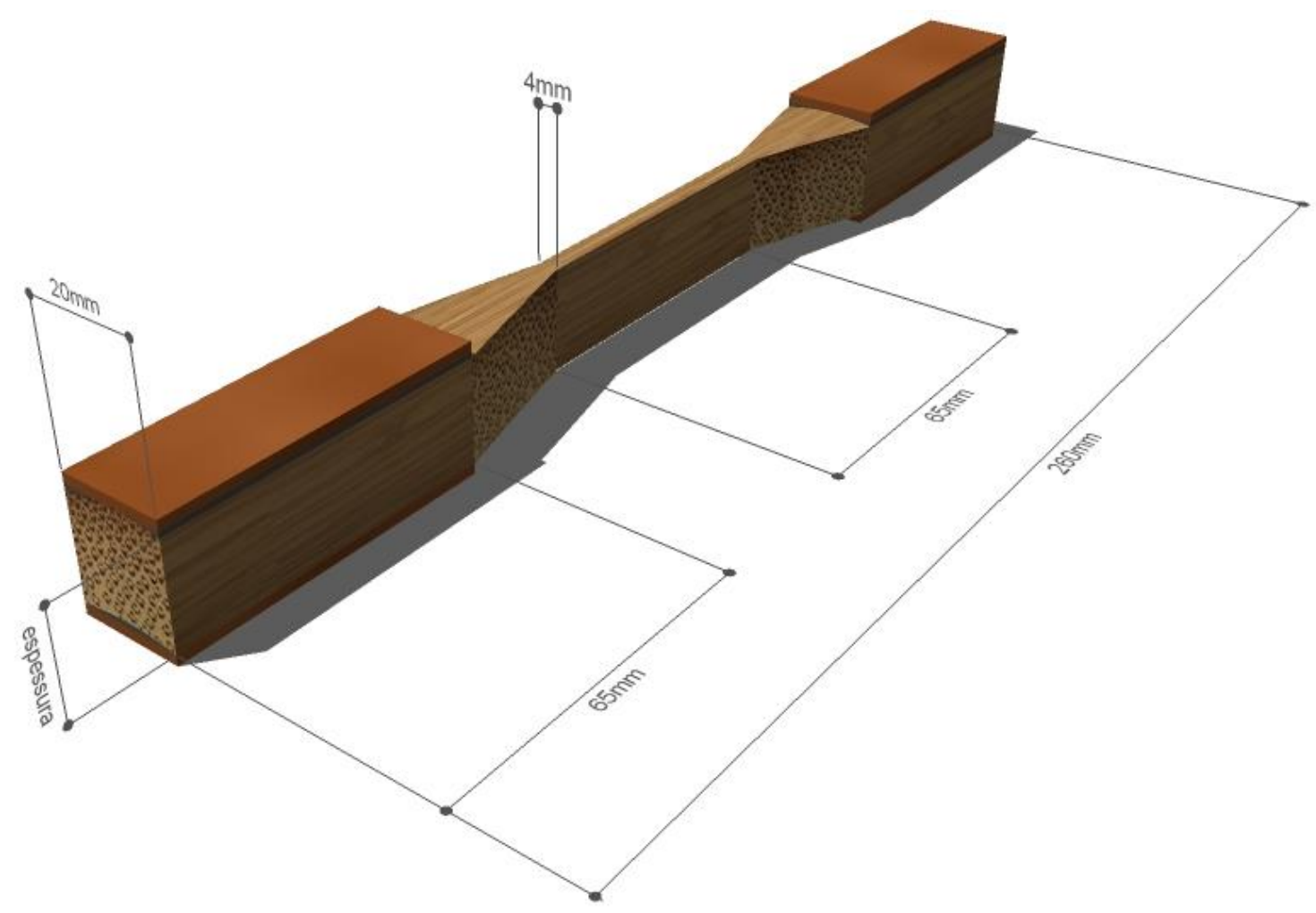

Figura 31: Corpo-de-prova de tração simples recomendado pela ISO 22157 [4].

Estes ensaios, recorrentemente, apresentam rupturas por cisalhamento alinhadas à zona de estricção e, por vezes sequer rompem à tração, principalmente em espécies de parede espessa. Em espécies de parede fina, por conta do menor diâmetro, a curvatura do bambu é proporcionalmente mais pronunciada, de modo que a pressão da garra perfaz um esforço de flexão em 3 pontos, que associado à tração, provoca ruptura alinhada com a zona de estricção (Figura 32a e Figura 32b). Nos corpos-de-prova de parede grossa, como a espessura da zona de estricção é muito inferior à espessura da parede do bambu (que corresponde à largura do corpo-de-prova), quando ocorre cisalhamento (sempre alinhado à zona de estricção) a garra não consegue manter a pressão na região tracionada e inicia-se um processo de deslizamento, impedindo a ruptura à tração do corpo-de-prova (Figura 32c e d).

Outro problema deste tipo de corpo-de-prova é o processamento. Os $20 \mathrm{~mm}$ na região de contato com a garra aliados à zona de estricção provocam desperdício de material e baixo aproveitamento. Além disso, a execução é bastante trabalhosa, requerendo $o$ uso de gabaritos e adaptações em ferramentas (tupia) para gerar o rebaixo central. 
5.
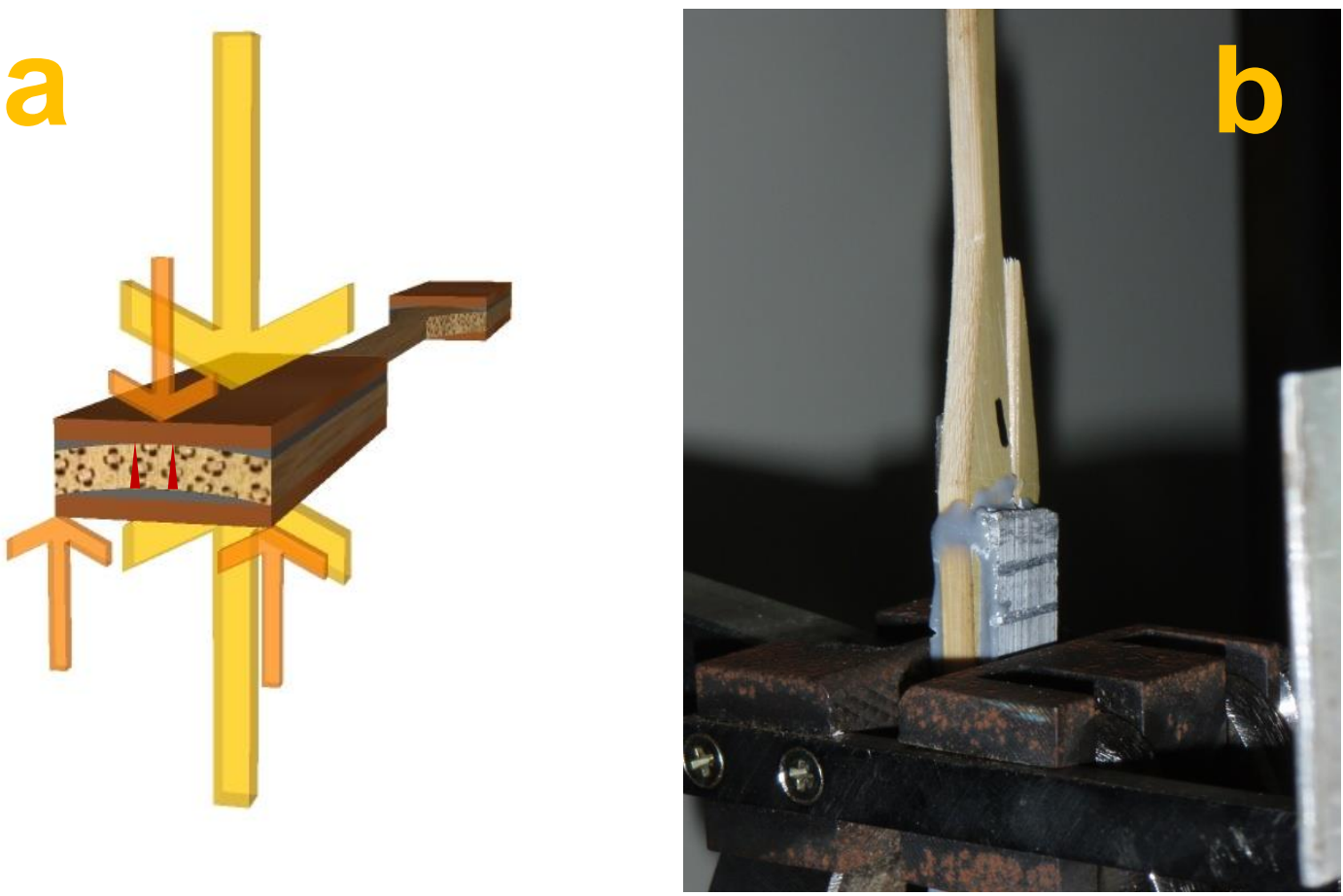

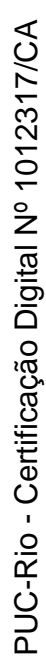
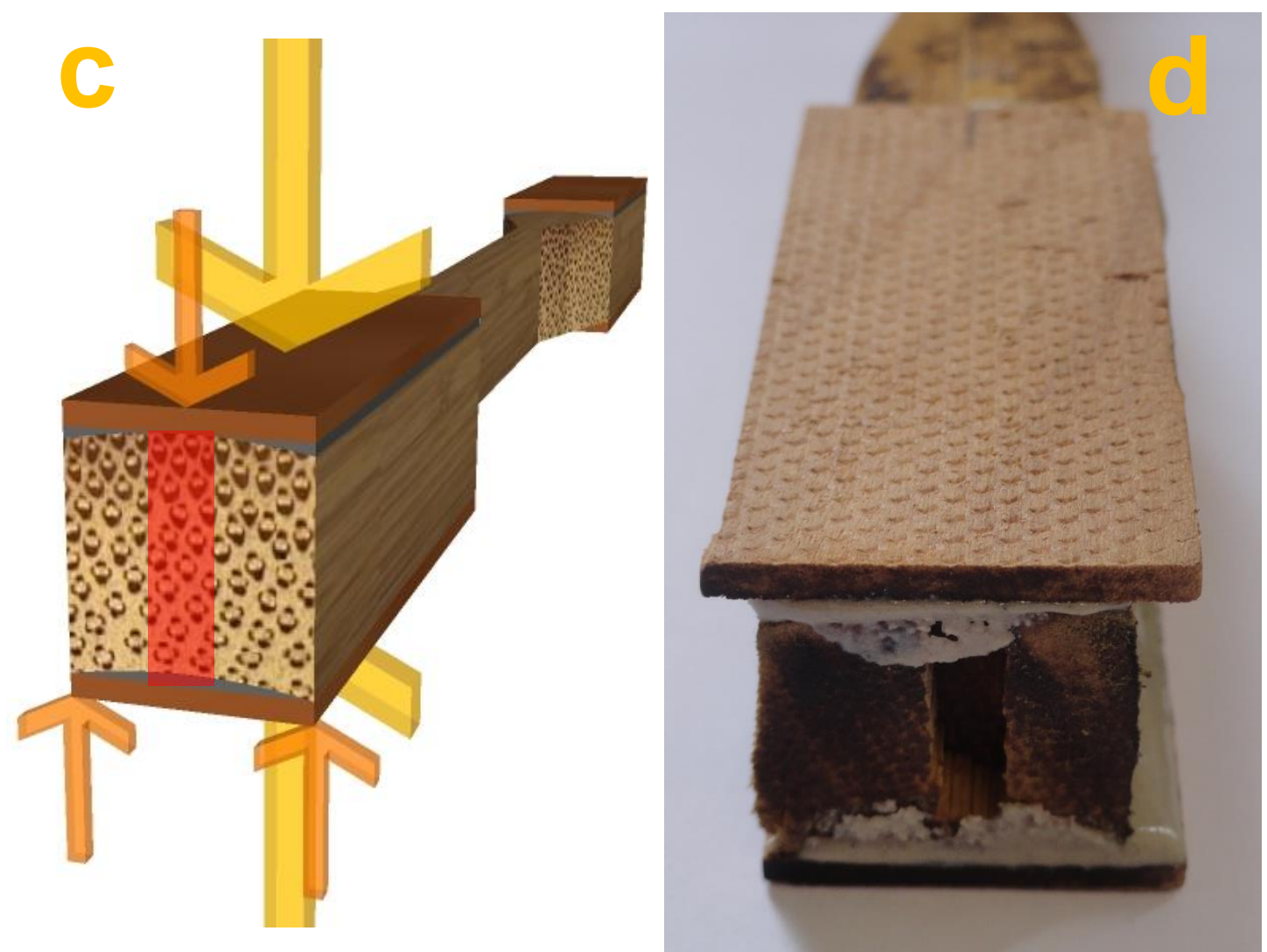

Figura 32: a) Flexão na região da garra em corpo-de-prova de parede fina. b) Cisalhamento alinhado com a zona de estricção em corpo-de-prova de parede fina [86]. c) Flexão na região da garra em corpo-de-prova de parede grossa. d) Cisalhamento alinhado com a zona de estricção e deslizamento em corpo-de-prova de parede grossa. 
5.

Partindo do pressuposto que se tem como objetivo caracterizar o bambu como material compósito, sugere-se adotar um corpo-de-prova derivado da norma ASTM D3039 [85] para propriedades mecânicas à tração de materiais compósitos com matriz polimérica, composto por uma lâmina simples de bambu com cerca de $2 \mathrm{~mm}$ de espessura, dotado ou não de reforços de madeira ou alumínio na região de contato com as garras (Figura 33).

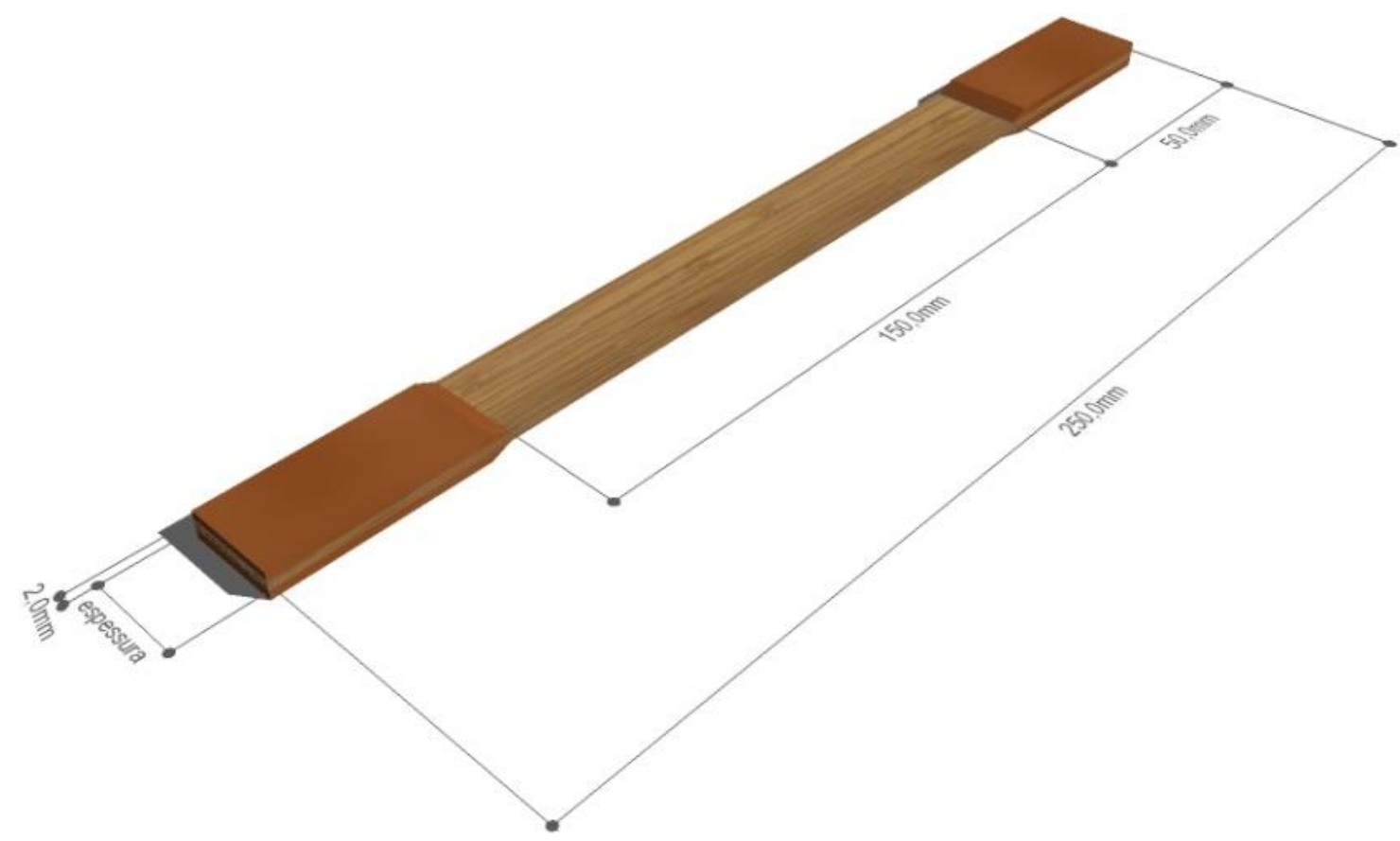

Figura 33: Corpo-de-prova de tração simples baseado nas recomendações da norma ASTM D3039 [85].

Esta proposta de corpo-de-prova atende de maneira uniforme a qualquer espessura de parede de bambu, bem como possibilita proceder, com a mesma metodologia, a ensaios de lâminas perpendiculares ao eixo radial do bambu. $A$ proposta elimina os trechos curvos e, por conseguinte, as zonas submetidas à flexão na região de contato com as garras.

O processamento é bastante simplificado, requerendo menos máquinas e mão-de-obra para gerar um corpo-de-prova de qualidade, proporciona um aproveitamento muito maior que o baseado na norma ISO e reduz drasticamente o desperdício de material. Além disso, como a espessura dos corpos-de-prova passa a ser padrão e a superfície regular, a colagem dos reforços na região de contato com a garra também é bastante facilitada, permitindo realizar o procedimento concomitantemente em diversos corpos-de-prova, gastando menos tempo e adesivo. Existe ainda a possibilidade de conduzir os ensaios 
5.

sem o reforço, desde que sejam realizados testes a priori e o modo de falha não seja alterado.

No intuito de comparar as metodologias de ensaio e validar a possibilidade de adotar a proposta conduz-se o procedimento experimental com corpos-deprova ISO e ASTM, com e sem diafragmas, provenientes das regiões basal, medial e apical do colmo.

Os ensaios de tração são controlados por deslocamento a uma taxa de $1 \mathrm{~mm} / \mathrm{min}$, utilizando o software Trapezium $X$, integrante da máquina. Para medir a deformação dos corpos-de-prova, são utilizados clip-gages Shimadzu SG 5050 posicionados no seu terço central. As tensões são obtidas por meio do carregamento, registrado pela célula de carga de $100 \mathrm{kN}$ da máquina, dividido pela área da seção ensaiada. O ambiente é condicionado, com temperatura de $21^{\circ} \mathrm{C}$. Durante os ensaios, uma máquina fotográfica Nikon $D 700$, ligada ao software Camera Control Pro, procede automaticamente à aquisição de imagens a intervalos regulares definidos pelo usuário, no caso 15 segundos. A Figura 34 apresenta os esquemas de ensaio, de acordo com ambas as normas.
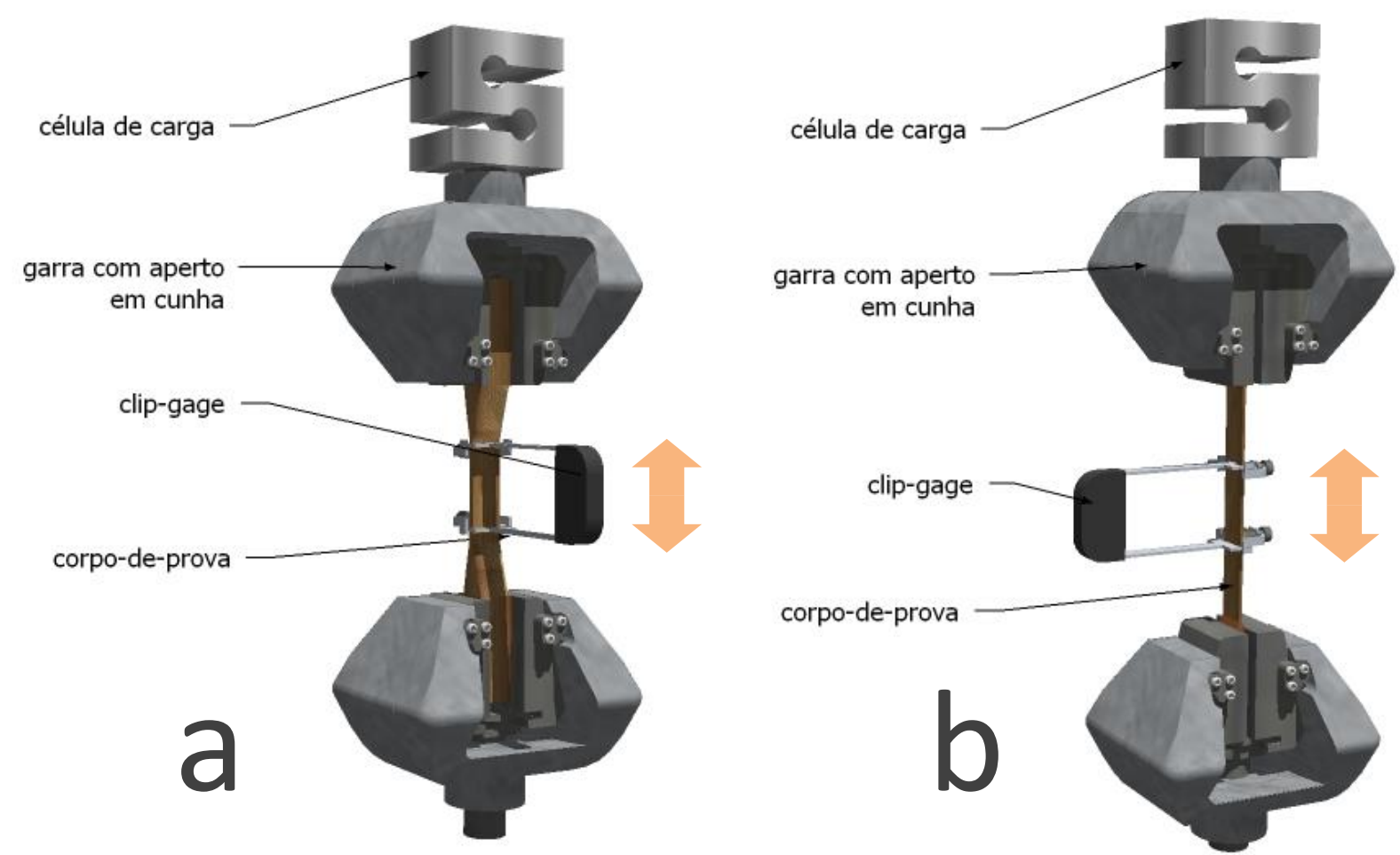

Figura 34: Esquema de ensaio de tração simples e detalhe do posicionamento do clip gage: a) conforme a ISO 22157 e b) conforme a ASTM D3039. 
5.

Foram ensaiados 3 corpos-de-prova para cada característica analisada: Norma adotada, ISO ou ASTM; região nodal ou internodal e posição no colmo, basal, medial ou apical, perfazendo um total de 36 ensaios. Antes de conduzir os ensaios, a umidade de cada corpo-de-prova é verificada utilizando um medidor de umidade para madeiras Minipa MWD-14A (Figura 35).

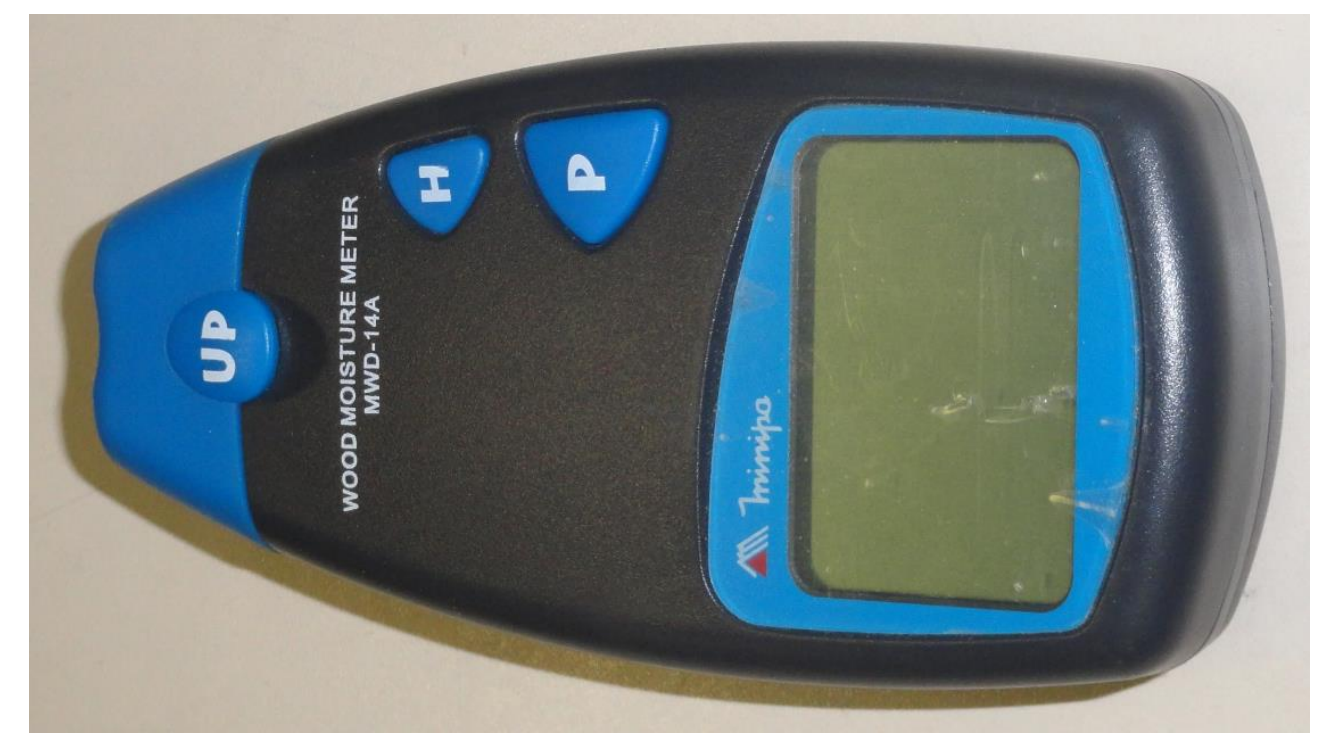

Figura 35: Medidor de umidade para madeiras da marca Minipa, modelo MWD-14A.

\subsection{Ensaios de compressão}

A Norma ASTM D3410 [87] é destinada à avaliação de corpos-de-prova de compressão de materiais compósitos de matriz polimérica, reforçados com fibras. Para a condução do ensaio, a referida norma requer um ferramental caro e/ou de execução trabalhosa, indisponível para esta pesquisa. Trata-se de uma pinça especial (Figura 36), que impede as rotações nas extremidades do corpode-prova. 
5.
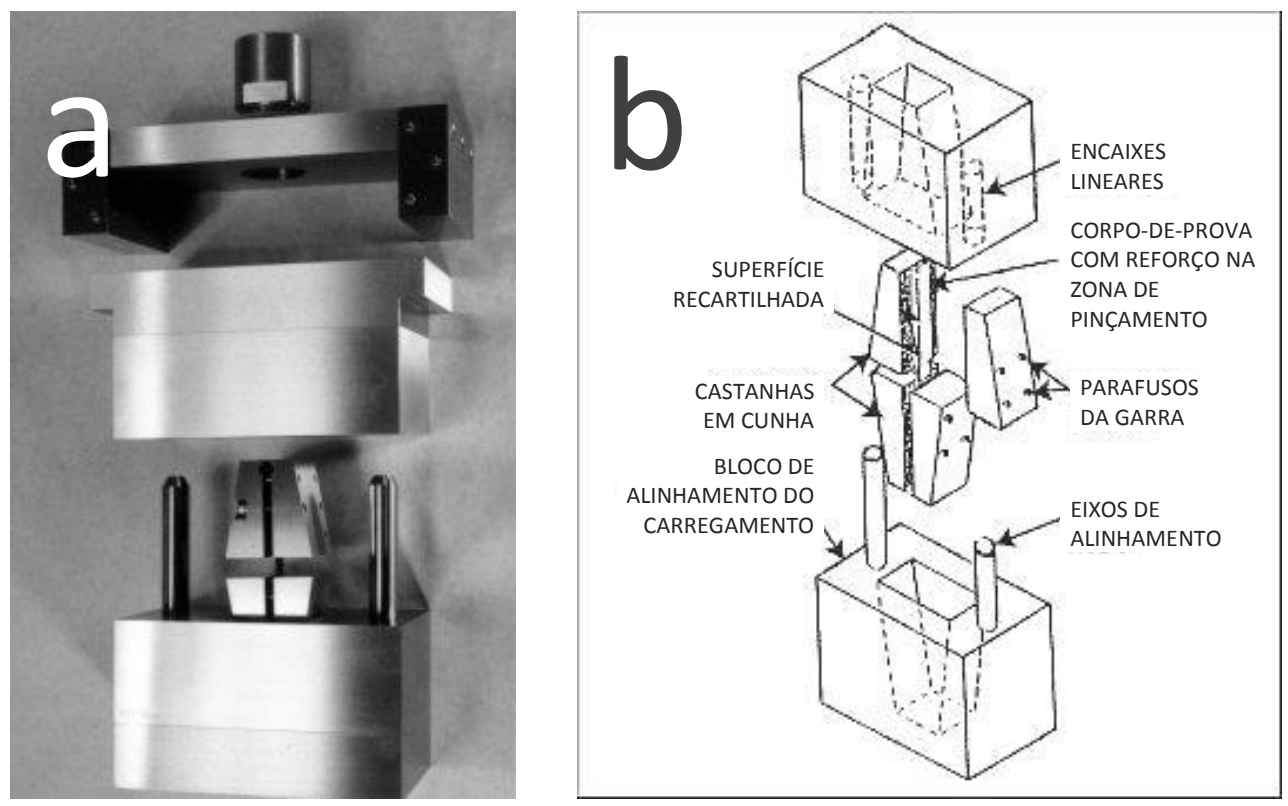

Figura 36: a) foto de garra específica para a condução do ensaio ASTM D3410 [88]; b) esquema das partes componentes da garra e do encaixe do corpo-de-prova na mesma [89].

Diante deste empecilho, propõe-se a confecção de um corpo-de-prova alternativo, com dimensões de seção e comprimento da região ensaiada constantes nas definições da norma, dotado de enrijecedores/estabilizadores nas extremidades, visando a diminuir os efeitos de rotação. Os enrijecedores são confeccionados utilizando cortes de $10 \mathrm{~mm}$ em tubos de PVC de $3 / 4$ " para os corpos-de-prova da região basal (parede mais espessa) e $1 / 2$ " para os das regiões medial e apical (gradualmente mais delgadas), preenchidos com massa plástica. O corpo-de-prova é uma lâmina de bambu com seção variável, cuja largura corresponde à dimensão completa da parede do colmo (eixo radial) e a espessura a $2 \mathrm{~mm}$ (eixo transversal ao radial). Possui $30 \mathrm{~mm}$ de comprimento, dos quais o terço central, de $10 \mathrm{~mm}$, representa a região ensaiada (Figura 37). 
5.

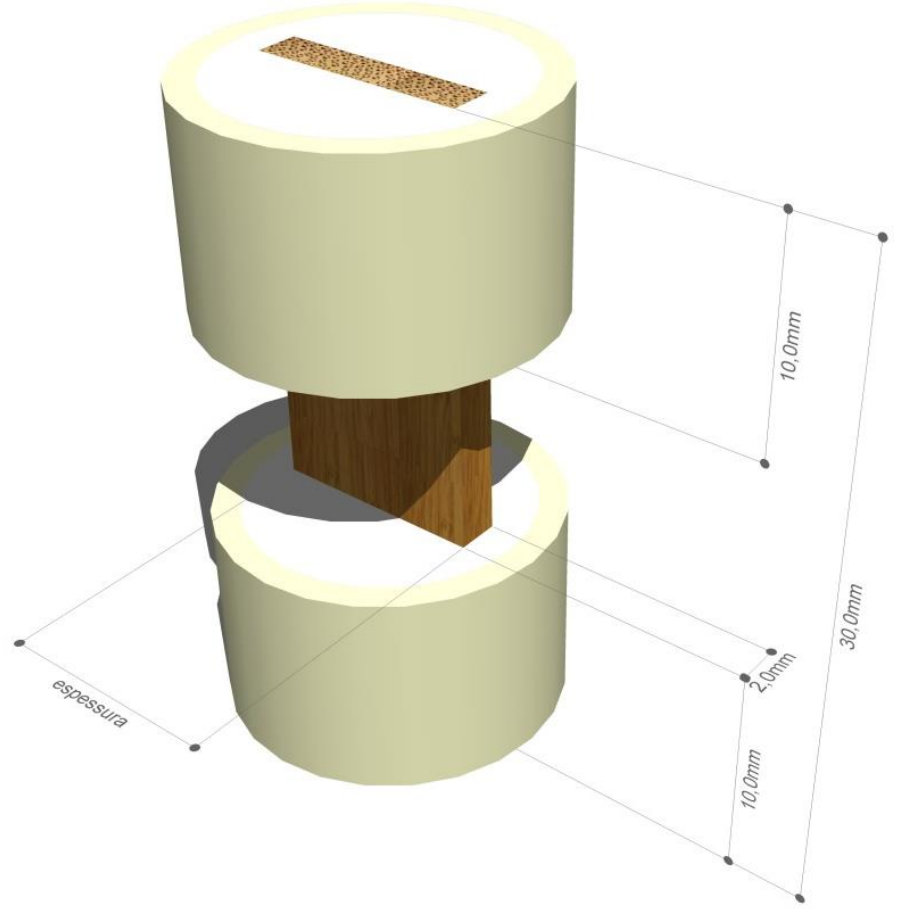

Figura 37: Corpo-de-prova de compressão adaptado a partir do recomendado pela Norma ASTM D3410 [87].

Os corpos-de-prova foram confeccionados a partir dos internós 6, 16 e 33, do colmo de Dendrocalamus giganteus proveniente da colheita de 2013, utilizando o gabarito de centralização descrito na Figura 7 associado a uma serra circular de bancada, para obter as taliscas; uma plaina desengrossadeira, para atingir a espessura final de $2 \mathrm{~mm}$ e uma serra de esquadrias para realizar os cortes a cada $30 \mathrm{~mm}$.

Os ensaios são controlados por deslocamento a uma taxa de $1 \mathrm{~mm} / \mathrm{min}$. Para medir a deformação se considera o deslocamento global, utilizando o software Trapezium $X$, integrante da máquina. As tensões são obtidas por meio do carregamento, registrado pela célula de carga de $100 \mathrm{kN}$ da máquina, dividido pela área da seção ensaiada. O ambiente é condicionado, com temperatura de $21^{\circ} \mathrm{C}$. Durante os ensaios, uma máquina fotográfica Nikon $D 700$, ligada ao software Camera Control Pro procede automaticamente à aquisição de imagens a intervalos regulares de 10 segundos. Foram testados 8 corpos-de-prova provenientes da porção basal, 9 da medial e 7 da apical, totalizando 24 ensaios. Dadas a dimensão e a geometria dos corpos-de-prova não foi possível averiguar o seu teor de umidade. A Figura 38 ilustra o esquema do ensaio à compressão conduzido. 
5.

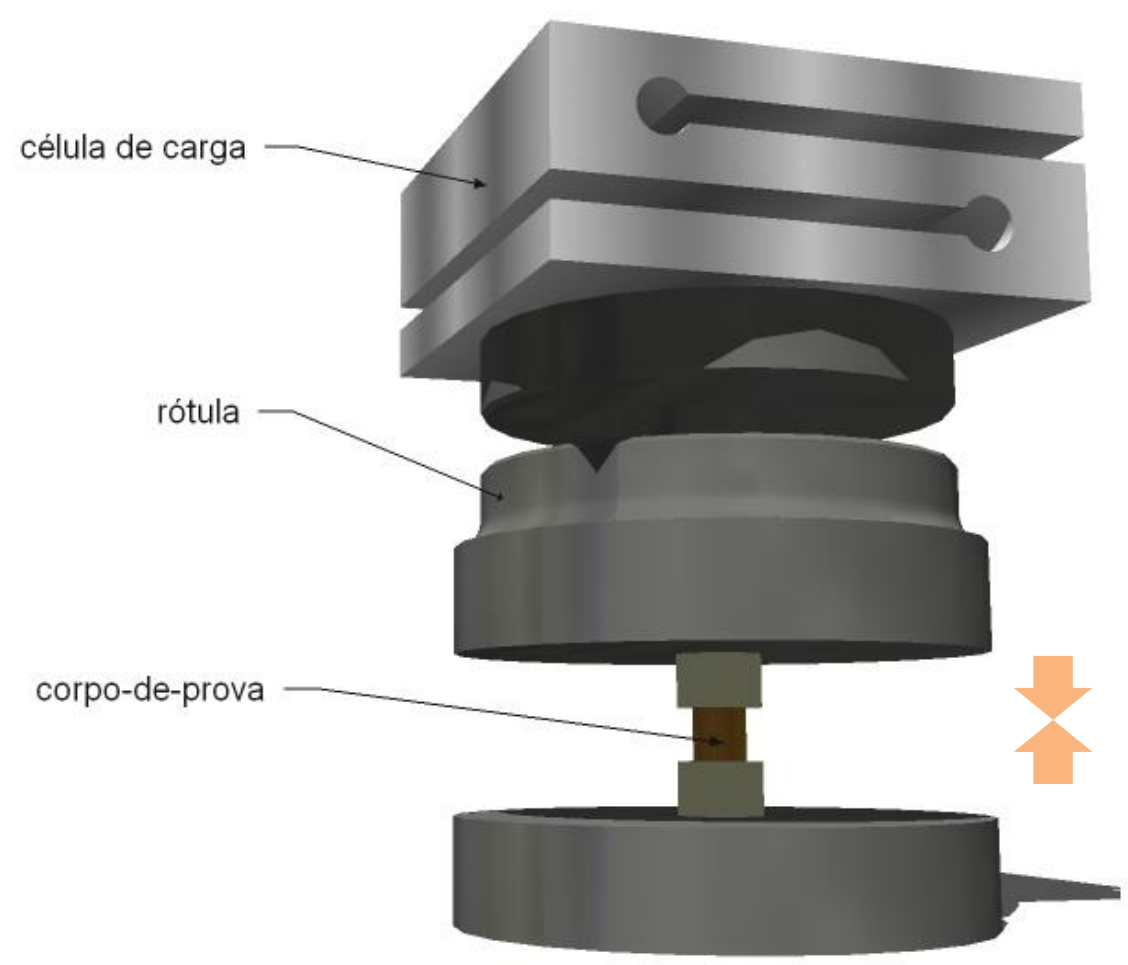

Figura 38: Esquema de ensaio à compressão simples, adaptado a partir do recomendado pela Norma ASTM D3410 [87].

\subsection{Ensaios de cisalhamento}

Para a determinação da tensão de cisalhamento interlaminar longitudinal às fibras, utiliza-se normas de estruturas de madeira adaptadas para bambu, de acordo com proposta de normalização de ensaio elaborada por Ghavami et al. [90]. Foram retirados três corpos-de-prova de cada um dos internós avaliados (numerados da base para o topo): 6, 7; 15, 16, 17; 31, 32 e 33, grupos representantes respectivamente das porções basal, medial e apical do colmo, provenientes da colheita de 2013.

Os corpos-de-prova foram elaborados utilizando uma serra circular de bancada associada ao gabarito de centralização anteriormente detalhado, para obter as taliscas; uma plaina desengrossadeira, para atingir a espessura final de $10 \mathrm{~mm}$ e uma serra de esquadrias para realizar os cortes a cada $200 \mathrm{~mm}$. Utilizando um arco de serra foram feitos dois entalhes de $1 \mathrm{~mm}$ de largura (plano radial $\mathrm{x}$ transversal) até $\mathrm{o}$ eixo de simetria longitudinal (plano radial $\mathrm{x}$ longitudinal), evitando transpassá-lo, o que poderia induzir a uma ruptura por esforço de tração, tornando o resultado pouco confiável. Os entalhes ocorrem na porção central da peça, distando $50 \mathrm{~mm}$ entre si e encontram-se em faces 
5.

opostas em relação ao eixo longitudinal. O modelo do corpo-de-prova é ilustrado na Figura 39.

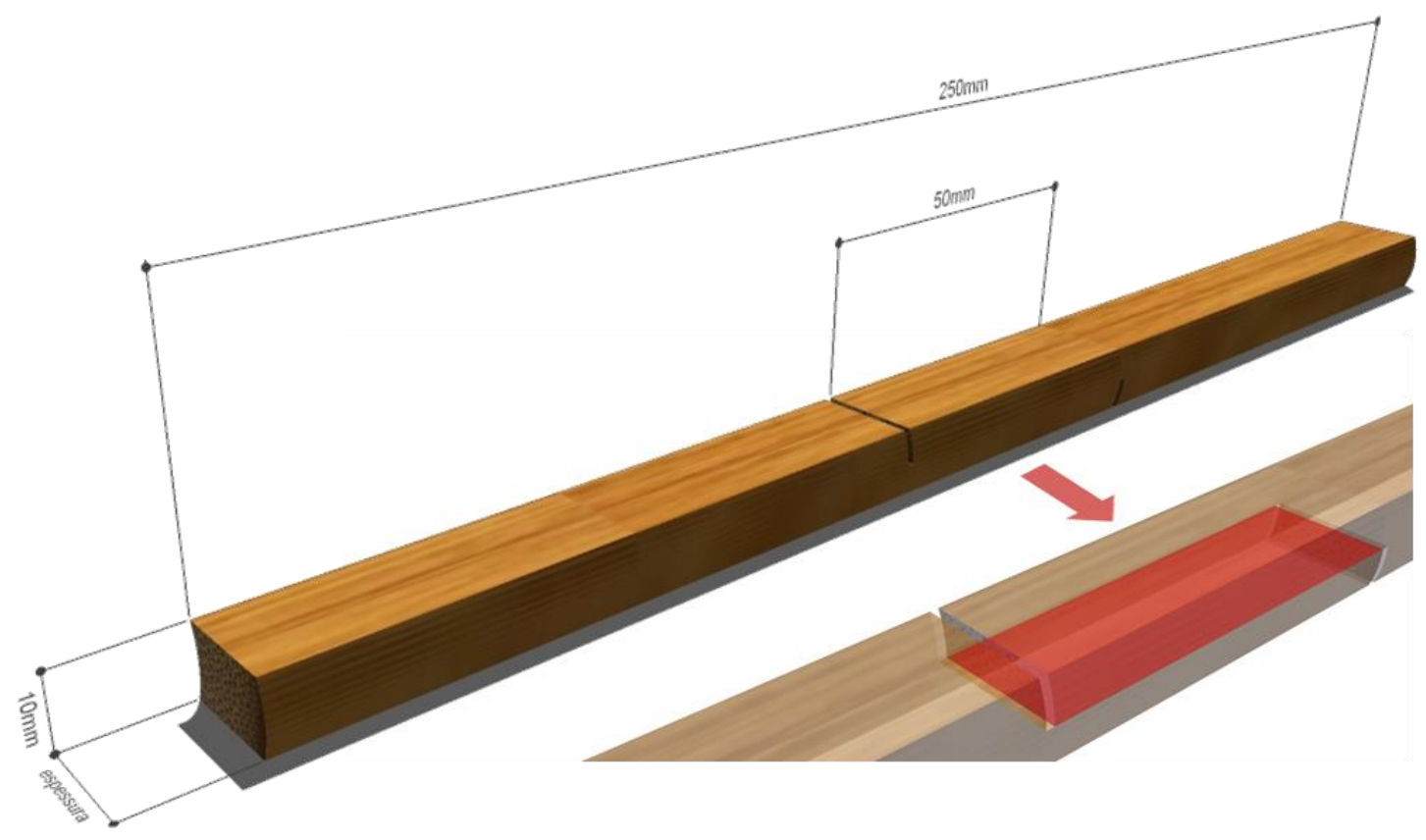

Figura 39: Corpo-de-prova de cisalhamento longitudinal proposto por Ghavami et al., [90], modificado a partir da ISO 22157 [4] e detalhe da seção ensaiada.

Os ensaios de cisalhamento são controlados por deslocamento a uma taxa de $1 \mathrm{~mm} / \mathrm{min}$ utilizando software integrante da máquina. A deformação dos corpos-de-prova é obtida utilizando clip-gage Shimadzu SG 25-25 posicionado entre os entalhes, na região central da peça. As tensões são obtidas por meio do carregamento, registrado pela célula de carga de 100 kN da máquina, dividido pela área de cisalhamento ensaiada (plano radial x longitudinal, entre o entalhes, exposto na Figura 39). O ambiente é condicionado, com temperatura de $21^{\circ} \mathrm{C}$. Durante os ensaios, uma máquina fotográfica procede automaticamente à aquisição de imagens a intervalos regulares de 10s. Três corpos-de-prova de cada porção do colmo foram ensaiados, perfazendo um total de nove ensaios. Antes de conduzir os ensaios, a umidade de cada corpo-de-prova é verificada utilizando um medidor de umidade para madeiras Minipa MWD-14A. A Figura 40 ilustra o esquema de ensaio. 
5.

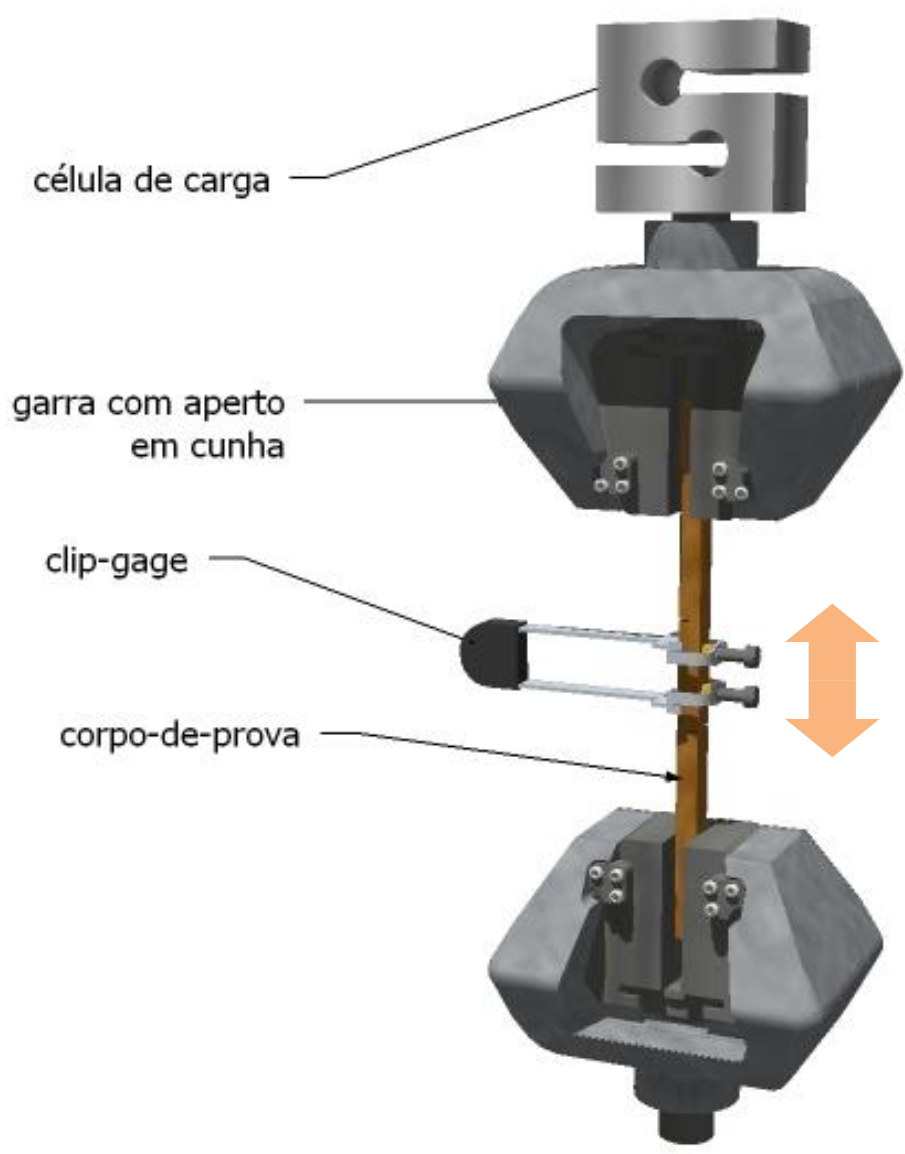

Figura 40: Setup de ensaio de cisalhamento simples proposto por Ghavami, et al., [90], modificado a partir da ISO 22157 [4].

\subsection{Resultados}

\subsubsection{Ensaios de tração}

As condições de realização e sumário dos resultados dos ensaios estão consolidados abaixo na Tabela 8 e na 
5.

Tabela 9.

Além das referências diretas à norma seguida pelo ensaio do corpo-deprova (ASTM ou ISO), a nomenclatura segue a lógica:

- T: refere-se a ensaios de tração;

- IN: refere-se a regiões internodais;

- $\quad \mathrm{N}$ : refere-se a regiões nodais;

- B: refere-se à região da base;

- M: região do meio;

- T: região do topo.

O número ao final (1 a 3) diferencia os corpos-de-prova de cada tipo.

Tabela 8: Lista de corpos-de-prova ASTM e ISO de regiões internodais com informações gerais sobre as condições de ensaio e registros de tensão máxima, deslocamento global máximo e modulo de elasticidade.

\begin{tabular}{|c|c|c|c|c|c|}
\hline corpos-de-prova & umidade (\%) & $\begin{array}{c}\text { erros / modo } \\
\text { de falha }\end{array}$ & $\sigma_{\text {máx }}$ & $\varepsilon_{\text {máx }}$ & $\mathrm{E}$ \\
\hline ASTMTINB1 & 6,00 & tração & 152,57 & 0,034 & 10,50 \\
\hline ASTMTINB2 & 3,00 & tração & 127,11 & 0,013 & 10,36 \\
\hline ASTMTINB3 & 10,00 & tração & 110,37 & 0,001 & 13,60 \\
\hline ASTMTINM1 & 10,00 & tração & 233,78 & 0,015 & 16,25 \\
\hline ASTMTINM2 & 4,00 & tração & 167,11 & 0,023 & 12,11 \\
\hline ASTMTINM3 & 10,00 & tração & 206,42 & 0,012 & 17,04 \\
\hline ASTMTINT1 & 2,00 & tração & 158,56 & 0,019 & 13,14 \\
\hline ASTMTINT2 & 6,00 & tração & 186,10 & 0,016 & 14,47 \\
\hline ASTMTINT3 & 6,00 & tração & 202,52 & 0,011 & 15,53 \\
\hline ISOTINB1 & 10,00 & cistesm ZTC & 127,97 & 0,009 & 9,33 \\
\hline ISOTINB2 & 15,00 & cis+esm ZTC & 175,87 & 0,006 & 14,08 \\
\hline ISOTINB3 & 14,00 & cistesm ZTC & 144,92 & 0,117 & 7,33 \\
\hline ISOTINM1 & 2,00 & cisZTC & 155,79 & 0,013 & 15,65 \\
\hline ISOTINM2 & 4,00 & cisZTC & 171,24 & erro & 20,90 \\
\hline ISOTINM3 & 3,00 & cistesm ZTC & 223,75 & 0,131 & 2,13 \\
\hline ISOTINT1 & 3,00 & cisZTC & 176,56 & 0,012 & 12,76 \\
\hline ISOTINT2 & 6,00 & cisZTC & 163,51 & 0,003 & 15,43 \\
\hline ISOTINT3 & 4,00 & cisZTC & 243,77 & 0,019 & 12,41 \\
\hline
\end{tabular}


5.

Tabela 9: Lista de corpos-de-prova ASTM e ISO de regiões nodais com informações análogas às apresentadas na Tabela 8.

\begin{tabular}{|c|c|c|c|c|c|}
\hline $\begin{array}{l}\text { corpos-de- } \\
\text { prova }\end{array}$ & umidade (\%) & $\begin{array}{c}\text { erros / modo } \\
\text { de falha }\end{array}$ & $\sigma_{\text {máx }}$ & $\varepsilon_{\text {máx }}$ & $E$ \\
\hline ASTMTNB1 & 4,00 & tração nó & 50,65 & 0,004 & 13,89 \\
\hline ASTMTNB2 & 2,00 & tração nó & 60,16 & 0,025 & 11,63 \\
\hline ASTMTNB3 & 4,00 & tração nó & 50,90 & 0,009 & 8,60 \\
\hline ASTMTNM1 & 7,00 & tração nó & 80,04 & 0,008 & 11,32 \\
\hline ASTMTNM2 & 10,00 & tração nó & 72,88 & 0,009 & 9,22 \\
\hline ASTMTNM3 & 4,00 & tração nó & 85,21 & 0,006 & 17,67 \\
\hline ASTMTNT1 & 2,00 & tração nó & 115,05 & 0,008 & 15,05 \\
\hline ASTMTNT2 & 5,00 & tração nó & 117,28 & 0,010 & 12,23 \\
\hline ASTMTNT3 & 3,00 & tração nó & 117,06 & 0,008 & 14,87 \\
\hline ISOTNB1 & 4,00 & tração nó & 54,93 & 0,013 & 10,37 \\
\hline ISOTNB2 & 3,00 & tração nó & 69,89 & 0,005 & 11,11 \\
\hline ISOTNB3 & 4,00 & tração nó & 76,49 & 0,038 & 2,53 \\
\hline ISOTNM1 & 5,00 & tração nó & 96,05 & 0,009 & 14,11 \\
\hline ISOTNM2 & 3,00 & tração nó & 72,30 & erro & erro \\
\hline ISOTNM3 & 3,00 & tração nó & 107,40 & 0,114 & 3,73 \\
\hline ISOTNT1 & 1,00 & tração nó & 106,81 & 0,013 & 9,54 \\
\hline ISOTNT2 & 1,00 & tração nó & 106,36 & 0,009 & 12,43 \\
\hline ISOTNT3 & 1,00 & tração nó & 127,46 & 0,012 & 14,68 \\
\hline
\end{tabular}

Qualitativamente, um dos pontos que chama mais a atenção (Tabela 8) é que nenhum dos corpos-de-prova ISO de regiões internodais rompeu efetivamente à tração, mas sim à cisalhamento, iniciado na zona de transição de carregamento (ZTC), alinhado com a zona de estricção (como evidencia a Figura 41 partes a, b, c e d) e eventualmente associado a esmagamento localizado na parte interna do colmo (que é menos densa, contém menos fibras e mais vazios) na área de contato com a garra (Figura 41 e). As fraturas dos corpos-de-prova de regiões nodais foram típicas, definidas por ruptura à tração na região do diafragma, tanto nos ensaios ISO como nos ASTM. 
5.
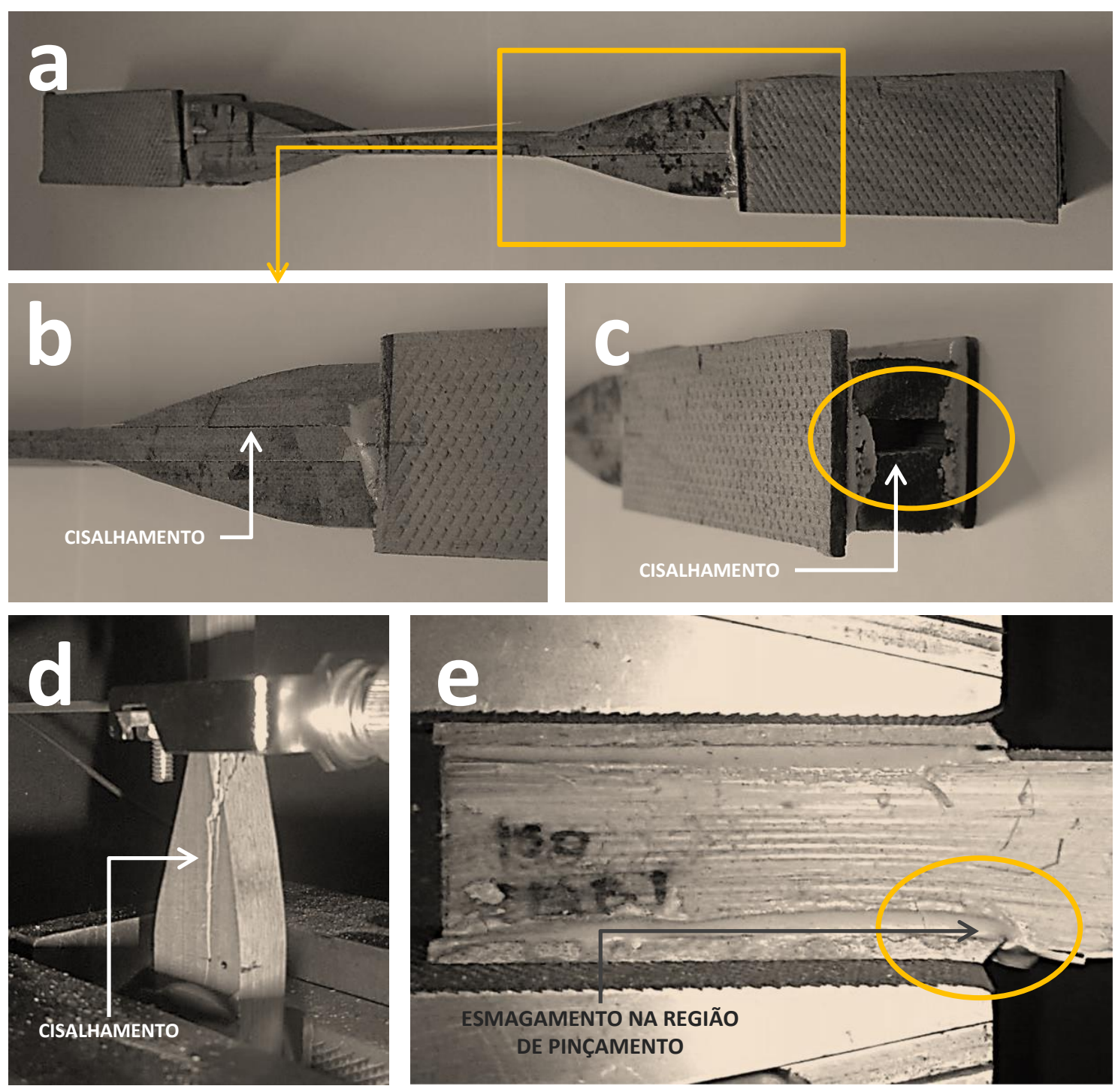

Figura 41: a) corpo-de-prova de tração ISO ensaiado, apresentando fissuras por cisalhamento; b) detalhe da fissura na zona de transferência alinhada com a zona de estricção; vista de topo do corpo-de-prova, evidenciando o deslizamento e a falha por cisalhamento; d) detalhe da fratura a cisalhamento alinhada com a zona de estricção, associado à abertura, porconta da curvatura natural do material; e) detalhe de esmagamento da parede interna na região de contato com a garra.

O modo de falha típico dos corpos-de-prova ASTM, por outro lado foi totalmente caracterizado por ruptura à tração. Observa-se que as fibras da parte mais externa da parede do colmo vão se rompendo individualmente e, em um dado momento ocorre a ruptura em bloco da porção interna da parede (Figura 42). 
5.

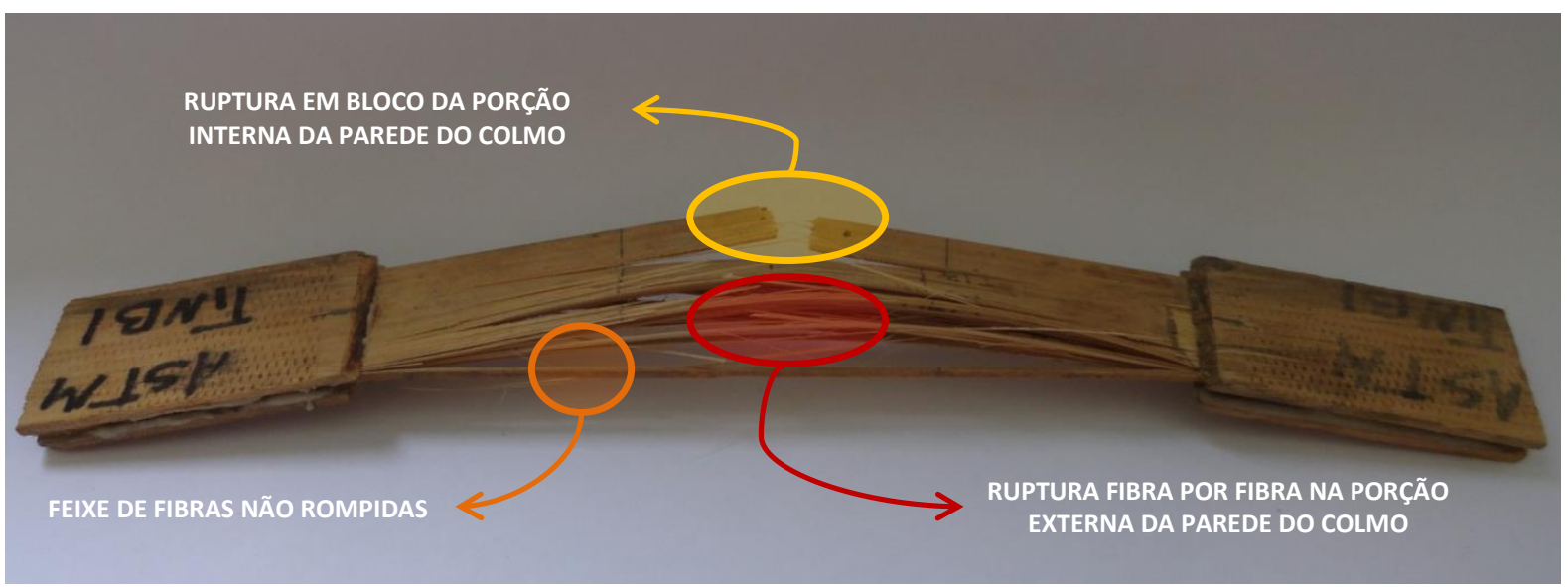

Figura 42: Modo de falha típico dos corpos-de-prova ASTM: ruptura a tração das fibras individualmente na porção externa da parede do colmo e em bloco na porção interna.

A razão da ocorrência deste modo de ruptura pode ser explicada com base na gradação funcional do material: A resistência e o módulo de elasticidade aumentam gradativamente, conforme aumenta a concentração de fibras, variando no eixo radial da parte interna para a parte externa. Ocorre, que a pressão da garra, sob esta configuração de ensaio (ASTM D 3039), é igual em todo o eixo radial, de modo que a região mais resistente e que deforma menos, dado o seu elevado módulo de elasticidade, inicia a sua ruptura, fibra por fibra, enquanto a região mais flexível continua se deformando elasticamente. A um dado momento, quando boa parte das fibras mais concentradas na camada externa se rompeu, o carregamento é desviado de forma relativamente brusca para a região mais flexível. Como tal carregamento é sempre superior à resistência nominal desta região ocorre a ruptura em bloco.

Na Figura 43 são apresentados os gráficos tensão x deformação (global) dos ensaios a tração ASTM (linhas cheias) e ISO (linhas tracejadas), das regiões internodal (esquerda) e nodal (direita), obtidos das porções (de cima para baixo) basal, central e apical de um colmo de bambu da espécie Dendrocalamus giganteus. Os gráficos são traçados utilizando o deslocamento global da máquina, que proporciona uma curva mais limpa e permite observar o comportamento do material durante e posteriormente ao início da ruptura. 
5.

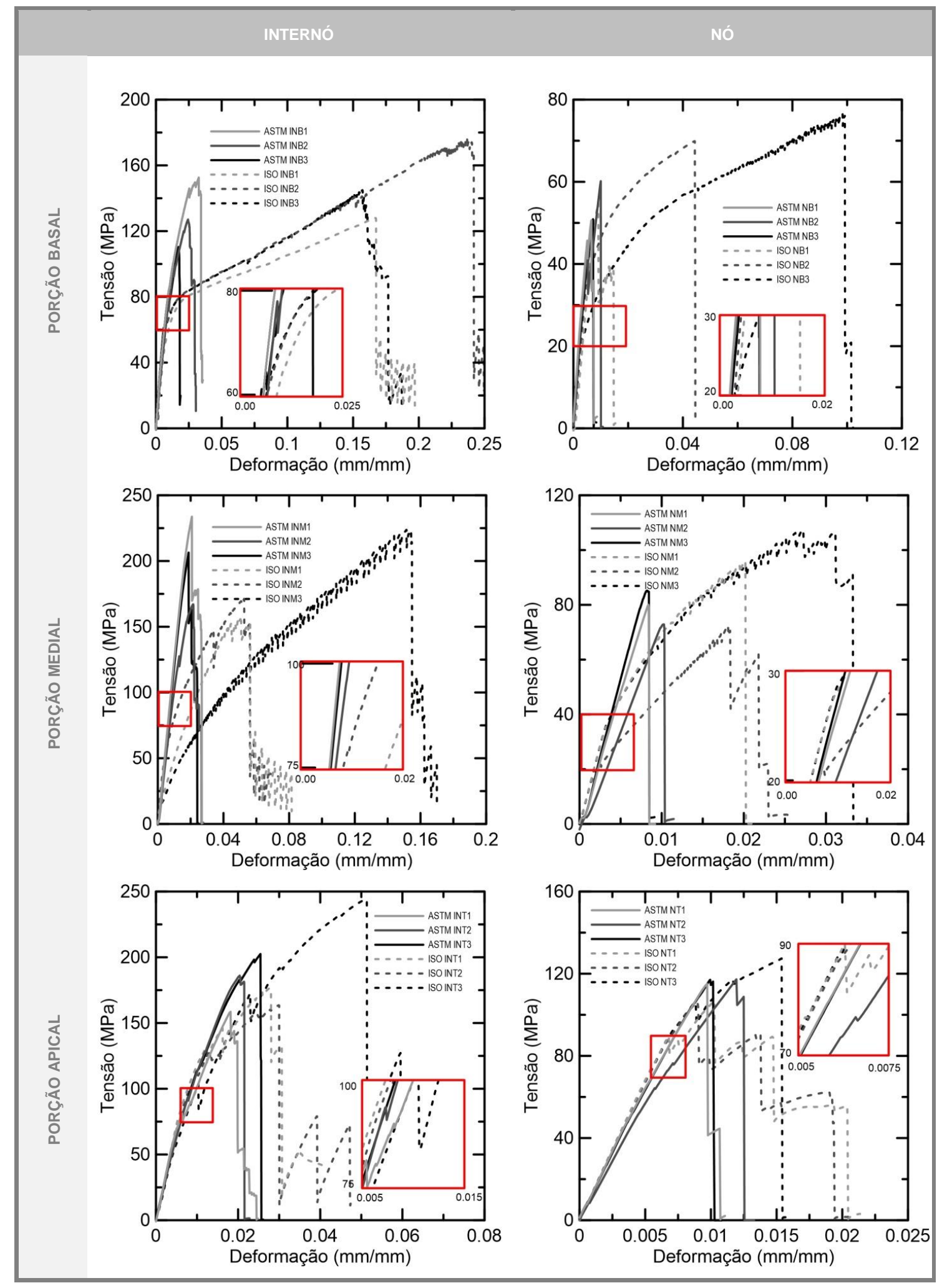

Figura 43: Gráficos tensão x deformação, ASTM (linhas preenchidas) e ISSO (pontilhadas), das regiões internodais (à esquerda) e nodais (à direita) em porções basais, mediais e apicais do colmo (de cima para baixo). 
5.

Analisando os resultados, percebe-se que o comportamento dos corposde-prova no início da fase elástica é bastante similar. Percebe-se, entretanto, que enquanto os corpos-de-prova ISO apresentam um decréscimo acentuado de rigidez, evidenciado por uma não linearidade acentuada fundamentalmente nas regiões internodais das porções basal e medial, enquanto os corpos-de-prova ASTM não apresentam variações bruscas no módulo de elasticidade, permanecendo, as curvas, praticamente lineares até a sua ruptura. Percebe-se que, conforme os corpos-de-prova se distanciam da região basal o decréscimo de rigidez se torna menos brusco e menos perceptível. No intuito de esclarecer esta relação foram plotadas conjuntamente curvas representativas (intermediárias mais próximas das médias de resistência e módulo de elasticidade) dos ensaios ISO e ASTM de base, meio e topo, conforme se pode observar na Figura 44.

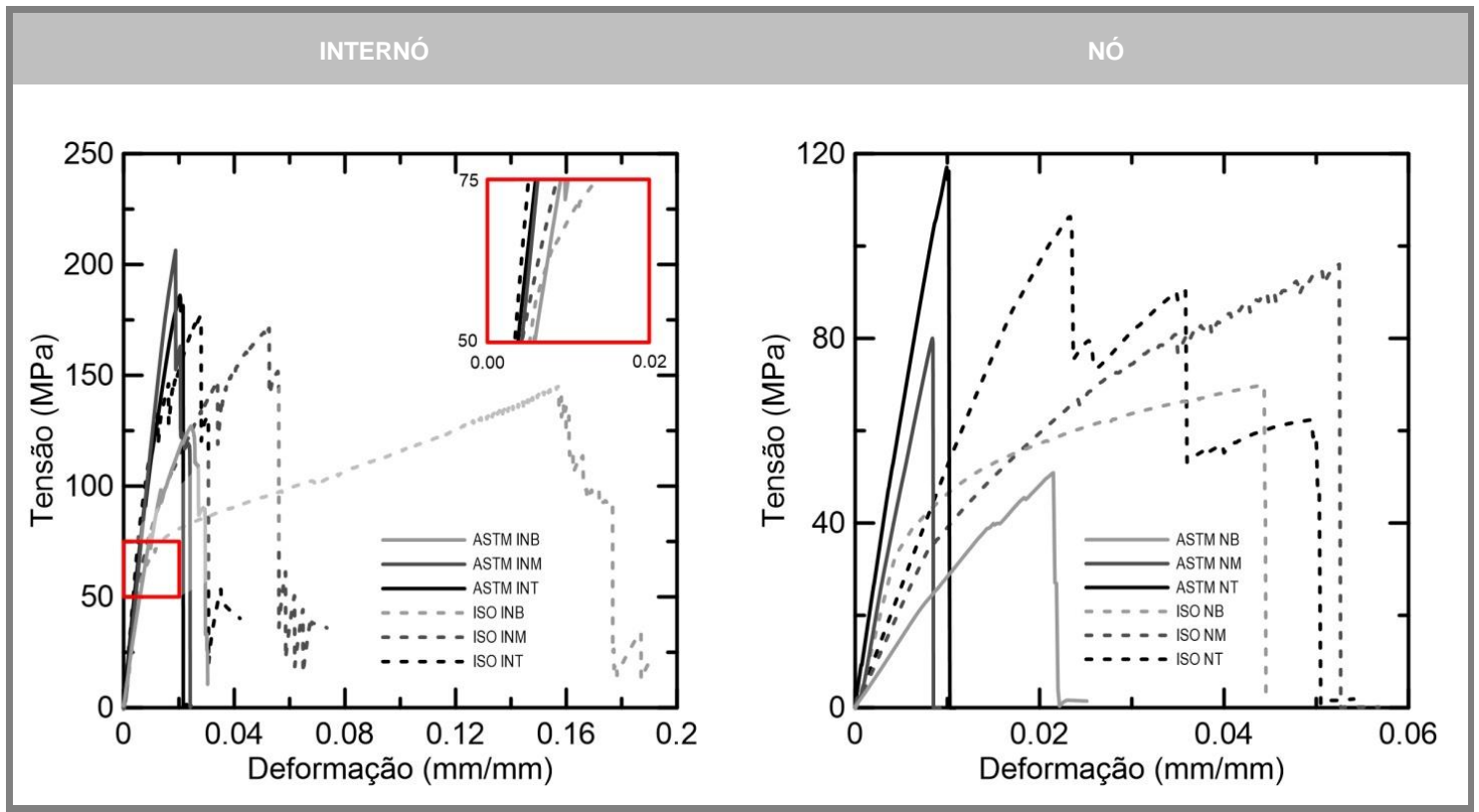

Figura 44: Gráficos tensão x deformação, ASTM e ISO, representativos das regiões internodais (à esquerda) e nodais (à direita) comparativos entre porções basais, mediais e apicais do colmo.

Percebe-se ainda que os ensaios ISO apresentam um padrão serrilhado que evidencia a ruptura por cisalhamento e os subsequentes patamares de deslizamento. A perda de rigidez evidente na Figura 43 e na Figura 44 pode ser explicada pela fissuração decorrente do esforço de cisalhamento ao qual os corpos-de-prova ISO são submetidos, que aumenta conforme aumenta a espessura da parede do colmo conforme explicitado anteriormente na Figura 32. 
5.

No intuito de refinar a comparação entre os corpos-de-prova obtém-se uma média a partir dos resultados de tensão máxima, deformação máxima equivalente (obtida no ponto de maior tensão) e módulo de elasticidade de cada tipo de corpo-de-prova. O resultado está disposto na Tabela 10.

Tabela 10: Tensões, deformações e módulos de elasticidade médios e seus respectivos desvios padrão.

\begin{tabular}{|l|c|c|c|c|c|c|}
\cline { 2 - 7 } corpos-de-prova & $\sigma_{\text {med }}$ & $\sigma_{\text {std }}$ & $\varepsilon_{\text {med }}$ & $\varepsilon_{\text {std }}$ & $E_{\text {med }}$ & $E_{\text {std }}$ \\
\hline ASTMTINB & 130,02 & 17,35 & 0,025 & 0,006 & 11,49 & 1,50 \\
\hline ASTMTNB & 53,90 & 4,43 & 0,008 & 0,002 & 11,38 & 2,17 \\
\hline ASTMTINM & 202,44 & 27,36 & 0,020 & 0,001 & 15,13 & 2,16 \\
\hline ASTMTNM & 79,38 & 5,06 & 0,009 & 0,001 & 12,74 & 3,59 \\
\hline ASTMTINT & 182,39 & 18,13 & 0,021 & 0,003 & 14,38 & 0,98 \\
\hline ASTMTNT & 116,46 & 1,01 & 0,011 & 0,001 & 14,05 & 1,29 \\
\hline ISOTINB & 149,59 & 19,83 & 0,023 & 0,001 & 10,25 & 2,83 \\
\hline ISOTNB & 67,11 & 9,02 & 0,010 & 0,001 & 8,00 & 3,88 \\
\hline ISOTINM & 183,59 & 29,09 & 0,085 & 0,047 & 12,89 & 7,91 \\
\hline ISOTNM & 91,92 & 14,63 & 0,022 & 0,004 & 8,92 & 5,19 \\
\hline ISOTINT & 194,61 & 35,17 & 0,036 & 0,011 & 13,53 & 1,35 \\
\hline ISOTNT & 113,54 & 9,84 & 0,012 & 0,003 & 12,22 & 2,10 \\
\hline
\end{tabular}

Com estes resultados pode-se relacionar a variação nas propriedades às regiões basal, medial e apical (posição no colmo, numerada da base ao topo adimensional) e a suas respectivas frações volumétricas de fibras (obtidas por tomografia e processamento digital de imagens), bem como determinar curvas que atendem a esta variação para cada tipo de corpo-de-prova (Figura 45, Figura 47 e Figura 48). 
5.
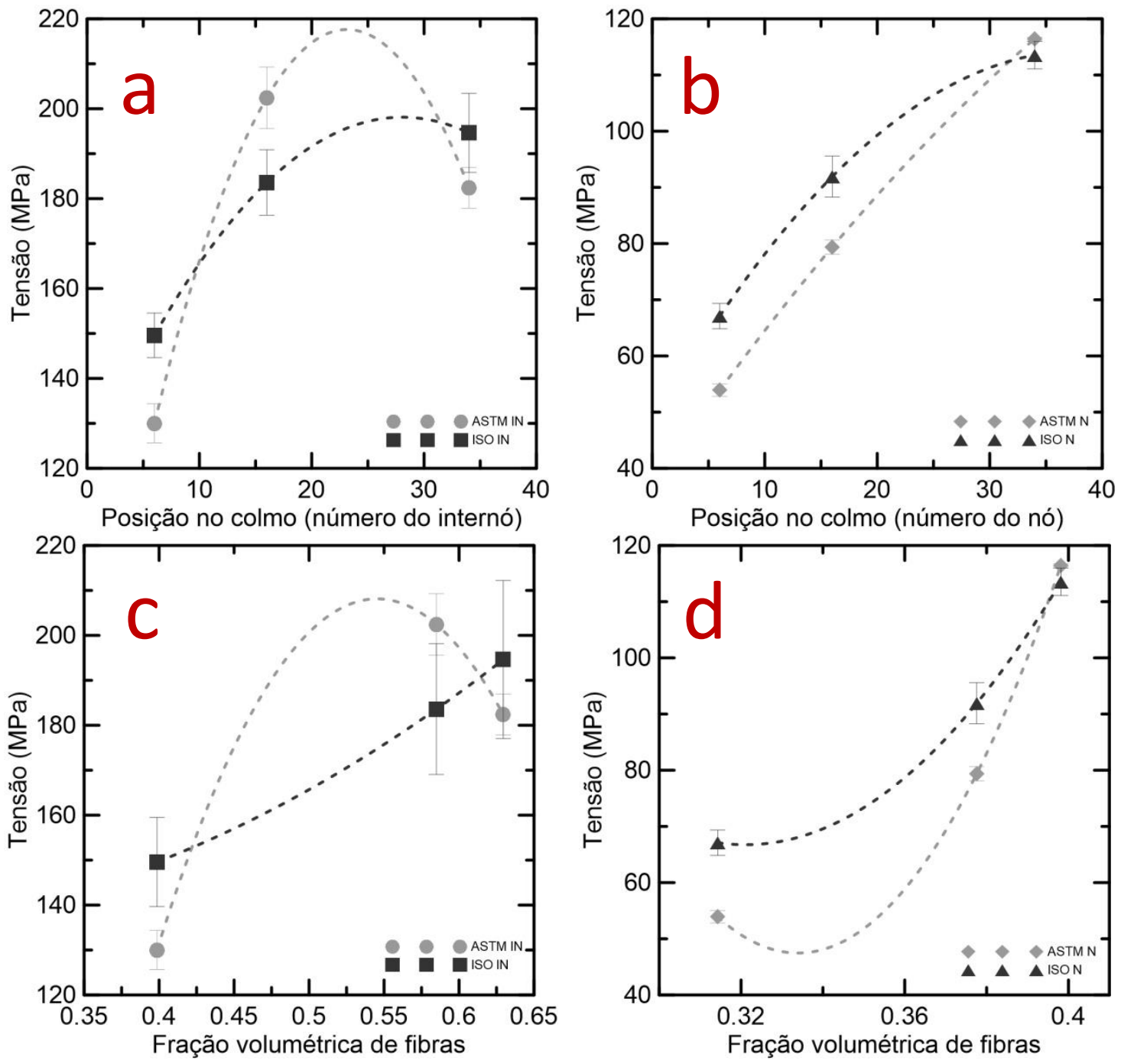

Figura 45: Relação entre a média das tensões de ruptura e: $(a, b)$ a posição no colmo e (c, d) a fração volumétrica de fibras dos corpos-de-prova ASTM e ISO de Dendrocalamus giganteus nas regiões $(a, c)$ internodais e $(b, d)$ nodais.

No que diz respeito aos cômputos de tensão de ruptura nas regiões nodais (Figura 45d) é possível associar o aumento médio ao incremento na fração volumétrica de fibras, embora seja uma correlação não linear da base ao topo do colmo. O mesmo não pode ser afirmado em relação às regiões internodais, tendo havido discrepância nos resultados gerais entre os ensaios ISO e os baseados na ASTM. Curiosamente, os ensaios ISO se aproximaram mais do resultado esperado a priori apresentando crescimento da tensão de ruptura conforme aumenta a fração volumétrica de fibras no material, apesar de os corpos-de-prova não terem se rompido à tração. Os ensaios baseados na norma ASTM apresentaram, na média, maior resistência para a região medial. Seria necessário conduzir mais ensaios para verificar se este padrão seria mantido, ou 
5.

se simplesmente trata-se de uma questão de heterogeneidade do material. É importante considerar que, quando da condução dos ensaios mecânicos, o posicionamento na garra dos corpos-de-prova ISO provoca compressão no eixo radial, o que influencia nos resultados conforme varia a espessura da parede (lagrura da seção ensaiada) e se reduz a proporção entre a espessura e a largura da seção ensaiada, incorrendo em redução da instabilidade associada à geometria em questão. Assim, independente da variação na fração volumétrica de fibras, um fator crítico de influência na rigidez e resistência máxima dos corpos-de-prova ISO é a espessura da parede do bambu, proporcionando resultados melhores, conforme esta se torna mais fina (Figura 46a). Tal problema não afeta os corpos-de-prova ASTM, cuja orientação de pinçamento pressiona o seu eixo circunferencial, proporcionando uma área de contato com a garra sempre superior à espessura do corpo-de-prova (Figura 46b).
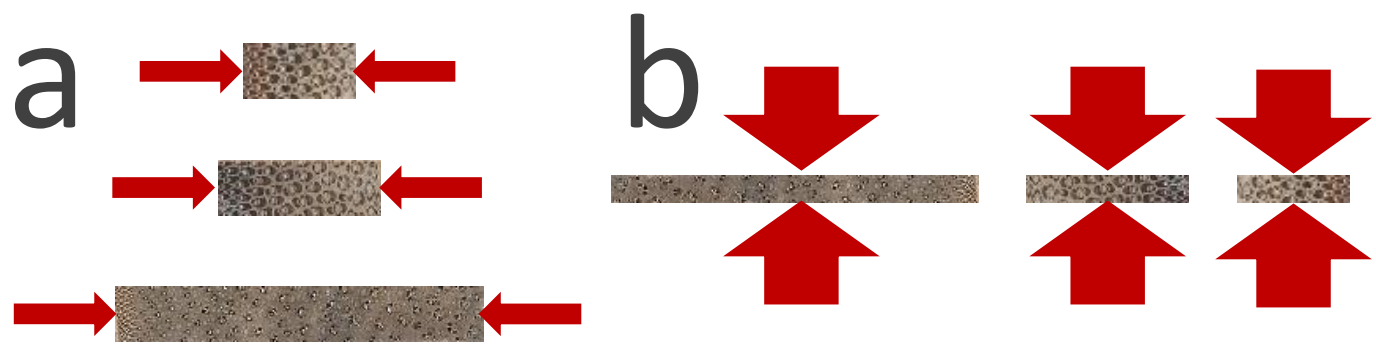

Figura 46: a) sentido de pressão da garra em corpos-de-prova ISO, de regiões basal, medial e apical (de baixo para cima) mostrando a variação na dimensão da largura do corpode-prova, correspondente à espessura da parede do colmo; b) sentido de pressão da garra em corpos-de-prova ASTM, de regiões basal, medial e apical (esquerda para a direita) mostrando a variação na dimensão da largura do corpo-de-prova, correspondente à espessura da parede do colmo.

Em relação à deformação global máxima, os corpos-de-prova ISO apresentaram acentuada não linearidade, destacando deformações na região medial muito pronunciadas, mantendo uma tendência geral de crescimento conforme aumenta a fração volumétrica de fibras tanto nos corpos-de-prova nodais como nos internodais. Nos corpos-de-prova ASTM a tendência é mais discreta e difere entre os corpos-de-prova com e sem diafragma. Nas regiões internodais ocorre diminuição discreta na deformação máxima enquanto nas regiões nodais ocorre um leve aumento. 
5.
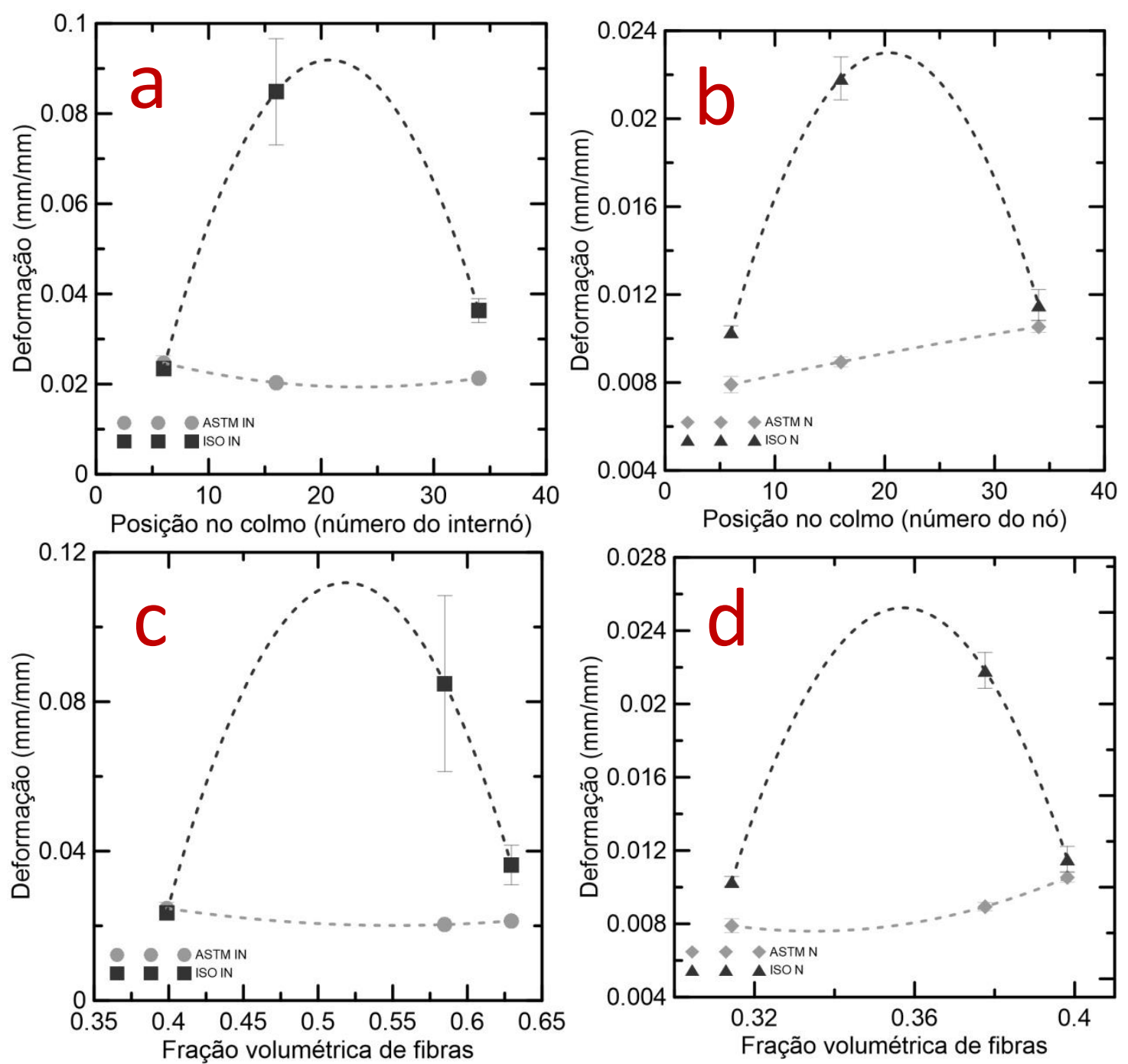

Figura 47: Relação entre a média das deformações globais máximas e: (a, b) a posição no colmo e (c, d) a fração volumétrica de fibras dos corpos-de-prova ASTM e ISO de Dendrocalamus giganteus nas regiões $(a, c)$ internodais $e(b, d)$ nodais.

Quanto ao módulo de elasticidade percebe-se um comportamento mais similar entre os corpos-de-prova ISO e ASTM. Os corpos-de-prova ISO de regiões internodais apresentam um comportamento de incremento de rigidez coerente com o aumento da fração volumétrica de fibras, embora não necessariamente diretamente relacionado a este fator exclusivamente. Nas regiões nodais há uma não linearidade menos evidente, mantendo a tendência de crescimento entre as porções basal e apical. Os corpos-de-prova internodais ASTM apresentam uma tendência não linear, em que os corpos-de-prova da porção medial do colmo apresentam um aumento muito grande de rigidez em 
5.

relação à região basal, seguido de uma queda perceptível para a porção apical, comportamento consistente com a variação observada nas tensões máximas.
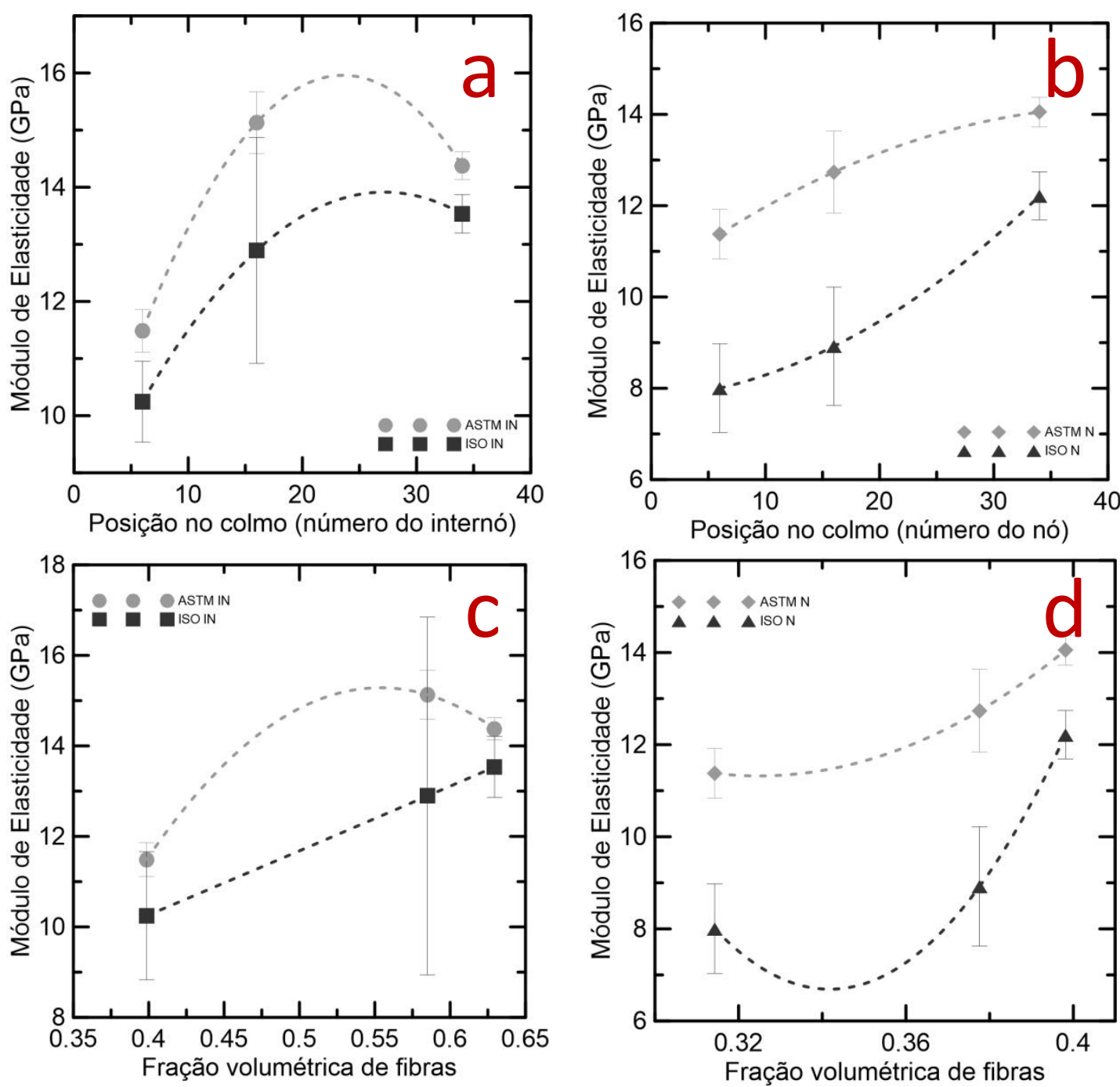

Figura 48: Relação entre a média dos módulos de elasticidade e: $(a, b)$ a posição no colmo e (c, d) a fração volumétrica de fibras dos corpos-de-prova ASTM e ISO de Dendrocalamus giganteus nas regiões $(a, c)$ internodais $e(b, d)$ nodais.

\subsubsection{Ensaios de compressão}

As condições de realização e sumário dos resultados dos ensaios estão consolidados abaixo na Tabela 11 e na Figura 49. Os gráficos são traçados utilizando o deslocamento global da máquina, que permite observar o comportamento do material durante e posteriormente ao início da ruptura.

A nomenclatura dos copros-de-prova segue a lógica:

- C: refere-se a ensaios de compressão; 
5.

- B: refere-se à região basal;

- M: região medial;

- T: região apical (topo);

- O número ao final diferencia os corpos-de-prova de cada tipo.

Tabela 11: Lista de corpos-de-prova de regiões internodais com informações gerais sobre os modos de ruptura e registros de tensão máxima, deformação global máxima equivalente e modulo de elasticidade.

\begin{tabular}{|c|c|c|c|c|}
\hline corpos-de-prova & modos de falha & $\sigma_{\text {máx }}$ & $\varepsilon_{\text {máx }}$ & $\mathrm{E}$ \\
\hline CB1 & rótulas plásticas (rp) & 73,75 & 0,03 & 2,82 \\
\hline CB2 & rp + esmagamento (esm) & 63,50 & 0,05 & 1,45 \\
\hline CB3 & esm & 73,34 & 0,03 & 2,50 \\
\hline CB4 & $\mathrm{rp}$ & 42,30 & 0,03 & 2,39 \\
\hline CB5 & $\mathrm{rp}$ & 37,83 & 0,04 & 1,04 \\
\hline CB6 & $\mathrm{rp}$ & 66,30 & 0,03 & 3,08 \\
\hline CB7 & $\mathrm{rp}+\mathrm{esm}$ & 75,86 & 0,03 & 3,29 \\
\hline CB8 & $r p+e s m$ & 49,69 & 0,03 & 0,91 \\
\hline CM1 & $\begin{array}{l}\text { flambagem (fla) + } \\
\text { cisalhamento tipo } 1 \text { (cis) }\end{array}$ & 92,30 & 0,03 & 2,82 \\
\hline CM2 & $r p+e s m$ & 96,33 & 0,03 & 3,93 \\
\hline CM3 & fla & 90,44 & 0,03 & 3,27 \\
\hline CM4 & $\mathrm{rp}+\mathrm{esm}$ & 90,74 & 0,04 & 3,68 \\
\hline CM5 & $\mathrm{rp}$ & 91,20 & 0,03 & 5,45 \\
\hline CM6 & esm & 96,61 & 0,04 & 3,54 \\
\hline CM7 & $\mathrm{rp}$ & 74,86 & 0,02 & 5,68 \\
\hline CM8 & esm & 80,23 & 0,05 & 3,88 \\
\hline CM9 & $r p+e s m+f l a$ & 87,48 & 0,06 & 1,36 \\
\hline СТ1 & esm & 83,26 & 0,04 & 3,67 \\
\hline СT2 & fla & 82,45 & 0,03 & 5,02 \\
\hline СТ3 & fla & 89,42 & 0,06 & 2,48 \\
\hline CT4 & fla & 92,40 & 0,04 & 3,77 \\
\hline CT5 & esm + fla + cis & 91,89 & 0,04 & 6,02 \\
\hline СТ6 & $\mathrm{rp}$ & 78,38 & 0,02 & 5,36 \\
\hline CT7 & $\mathrm{rp}$ & 88,53 & 0,03 & 4,69 \\
\hline
\end{tabular}


5.
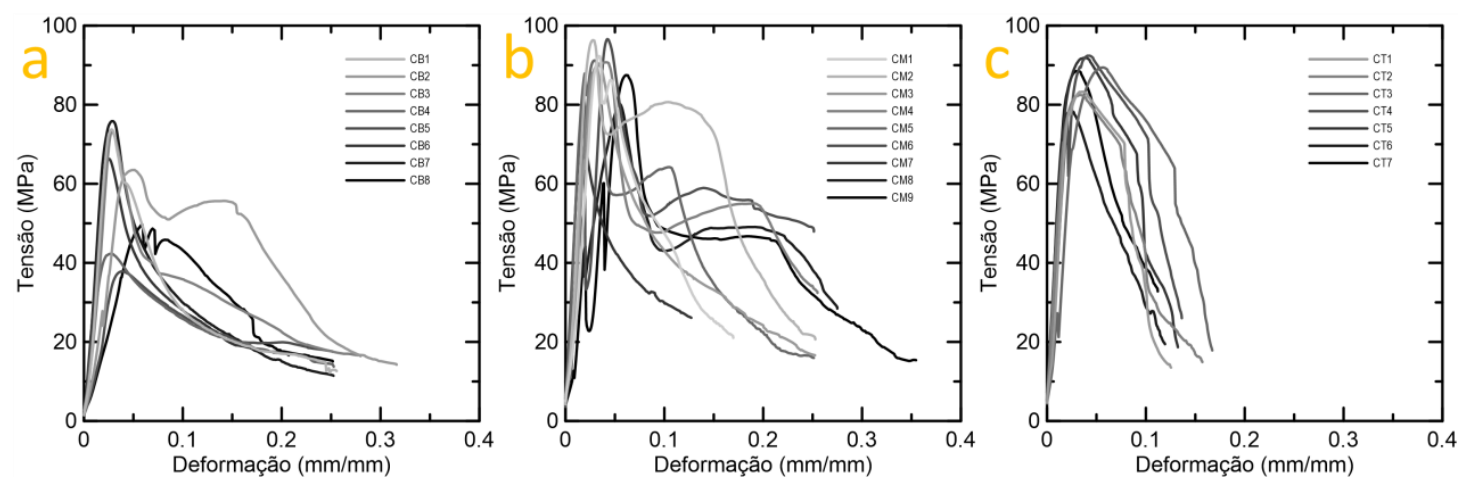

Figura 49: Curvas tensão $x$ deformação dos ensaios à compressão para as porções: a) basal; b) medial e c) apical.

O sumário com as médias e desvios padrão dos resultados dos ensaios estão consolidados abaixo na Tabela 12 e na Figura 50.

Tabela 12: Valores médios e desvios padrão associados das propriedades mecânicas à compressão obtidas experimentalmente para as porções basal, medial e apical de regiões intermodais de bambu da espécie Dendrocalamus giganteus.

\begin{tabular}{|l|c|c|c|c|c|c|}
\cline { 2 - 7 } corpos-de-prova & $\sigma_{\text {med }}$ & $\sigma_{\text {std }}$ & $\varepsilon_{\text {med }}$ & $\varepsilon_{\text {std }}$ & $E_{\text {med }}$ & $E_{\text {std }}$ \\
\hline CB & 60,32 & 14,06 & 0,034 & 0,007 & 2,19 & 0,87 \\
\hline CM & 88,91 & 6,76 & 0,037 & 0,012 & 3,73 & 1,23 \\
\hline CT & 86,62 & 4,92 & 0,037 & 0,012 & 4,43 & 1,11 \\
\hline
\end{tabular}

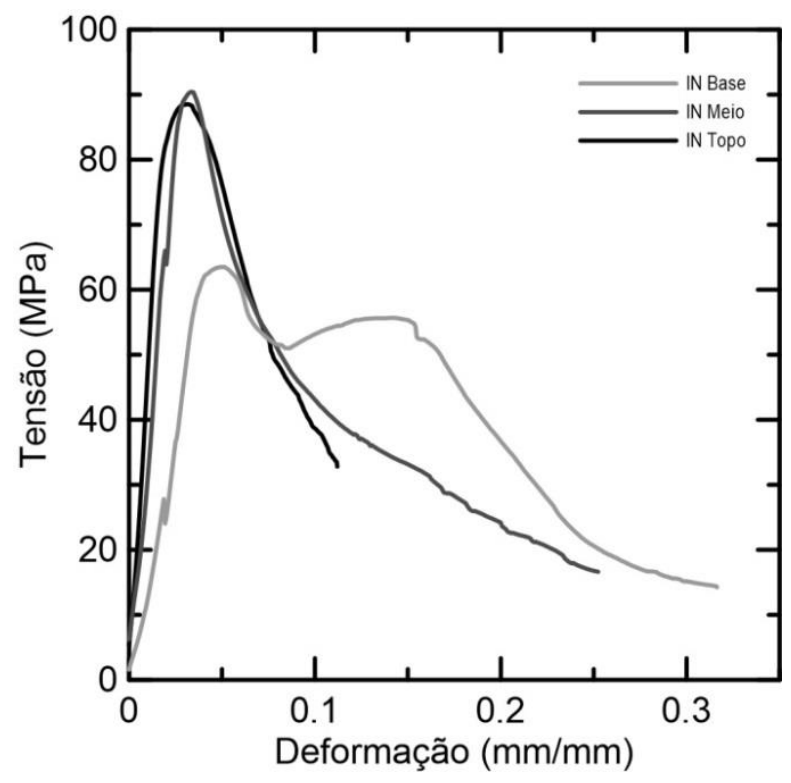

Figura 50: Curvas tensão $\mathrm{x}$ deformação representativas de corpos-de-prova ensaiados, provenientes de regiões intermodais das porções basal, medial e apical do colmo. 
5.

Observa-se, tanto pelos valores médios, como pela curvas típicas, que o desempenho mecânico dos corpos-de-prova provenientes das regiões medial e apical são bastante similares. Os resultados apontam que a região medial é ligeiramente mais resistente e a apical ligeiramente mais rígida. A resistência dos corpos-de-prova provenientes da região basal é de cerca de $25 \%$ inferior à das demais regiões. Sua rigidez representa, na média, $59 \%$ da verificada para a região medial e $49 \%$ da relativa à região apical.

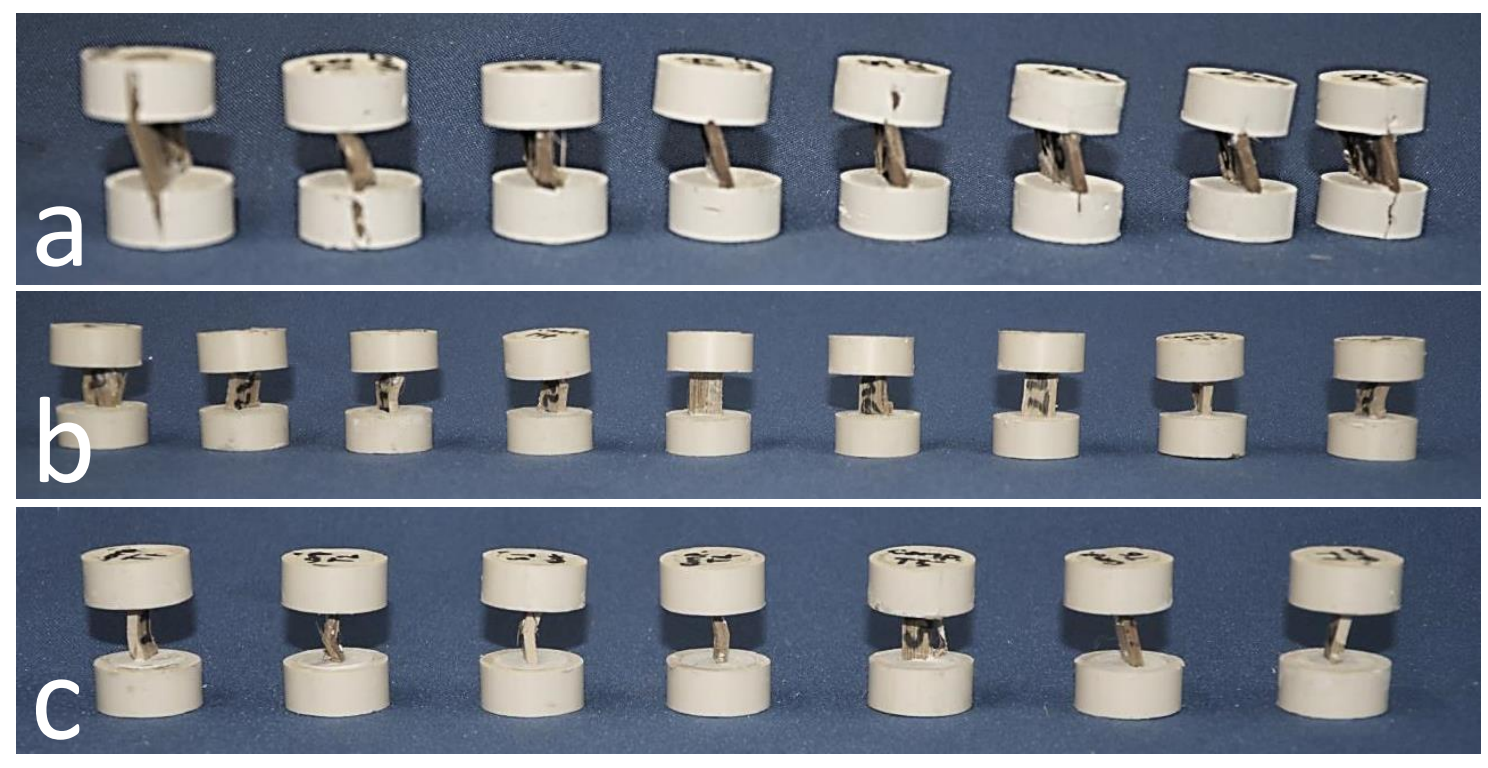

Figura 51: corpos-de-prova de compressão ensaiados. Visão global dos modos de falha típicos. a) região basal; b) região medial; c) região apical.

Os modos de falha, ilustrados de um modo geral pela Figura 51, podem ser separados em quatro grandes grupos com mecânicas próprias além de um quinto com associações entre os demais (Figura 52):

Grupo 1: Inclinação e criação de rótulas plásticas junto aos engastes. Este modo de falha não é o ideal, pois, na prática, a ruptura não se dá à compressão simples. Este modo ocorre por uma falha de posicionamento do corpo-de-prova na máquina universal de ensaios, provocando uma excentricidade que induz a rótula a um movimento precipitado. Tal efeito também pode ser provocado ou por irregularidades geométricas intrínsecas ao corpo-de-prova, mas, no caso, estas foram minimizadas no processo de confecção. Este tipo de ruptura poderia ser minimizado retirando a rótula do esquema de ensaio, assim esta falha 
5.

necessariamente seria devida às irregularidades intrínsecas, que podem ser controladas na origem, conforme anteriormente mencionado;

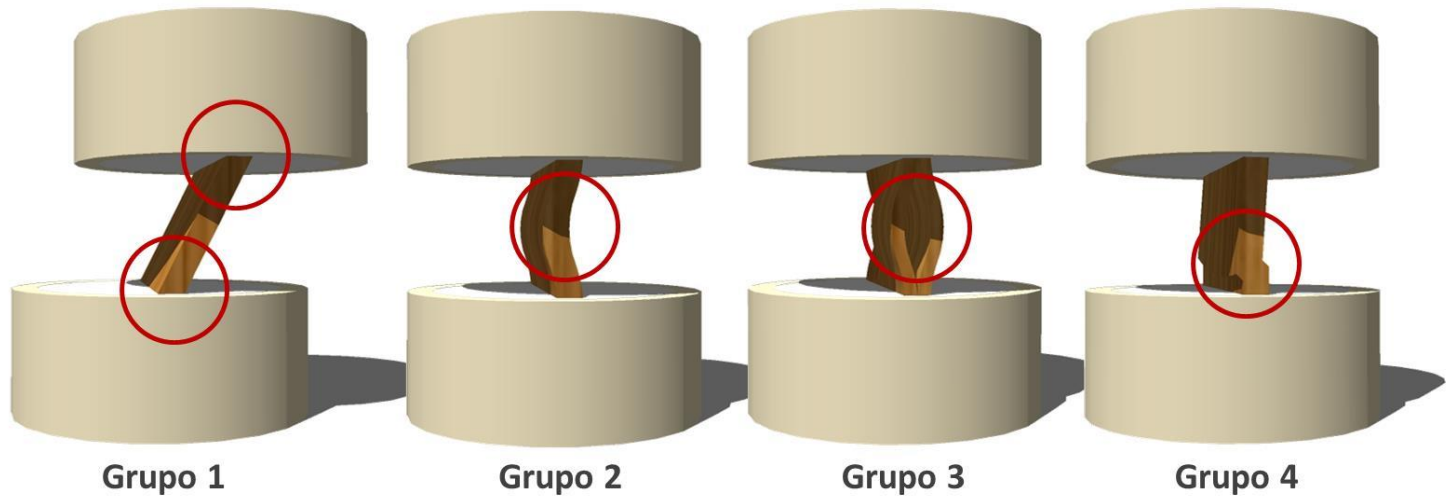

Figura 52: Separação por grupos com as principais características dos modos de ruptura associados aos ensaios de compressão.

Grupo 2: Flambagem na região central da área ensaiada, seguida de esmagamento do trecho mais comprimido;

Grupo 3: Flambagem associada a a cisalhamento tipo 1 (abertura), dado que parte das fibras pode flambar para um lado e parte para o outro, provocando a abertura. Com o cisalhamento, dado que conjuntos de fibras se dividem, ocorrem rupturas sequenciais à flexão dos blocos isolados;

Grupo 4: Flambagem local e esmagamento, em geral próximo a um dos engastes, embora possa ocorrer na porção central. Ocorre quando simultaneamente várias fibras entram em processo de flambagem local, junto ao ponto de maior tensão, normalmente próximo aos engastes, minimizando a ação de momento fletor. Esta ruptura é, dentre as observadas, a mais próxima de uma falha por compressão simples;

Grupo 5: Falhas combinadas entre os demais grupos.

Nos ensaios da porção basal houve maior incidência de rupturas do Grupo 1 (Figura 53a), por conta da maior área comprimida, que diminui proporcionalmente o efeito da flambagem. Na pratica, a largura do corpo-deprova é maior que a sua altura efetiva. Ademais, por ser a primeira série de ensaios deste tipo o esquema de posicionamento dos corpos-de-prova ainda não estava bem operacionalizado, o que foi corrigido nas séries seguintes. Numa visão geral, $50 \%$ dos corpos-de-prova desta porção do colmo apresentaram mecanismo de falha enquadrável como Grupo 1, 12,5\% Grupo 4 (Figura 53b) e 
5.

37,5\% Grupo 5, com participação da formação de rótulas plásticas no modo de ruptura.
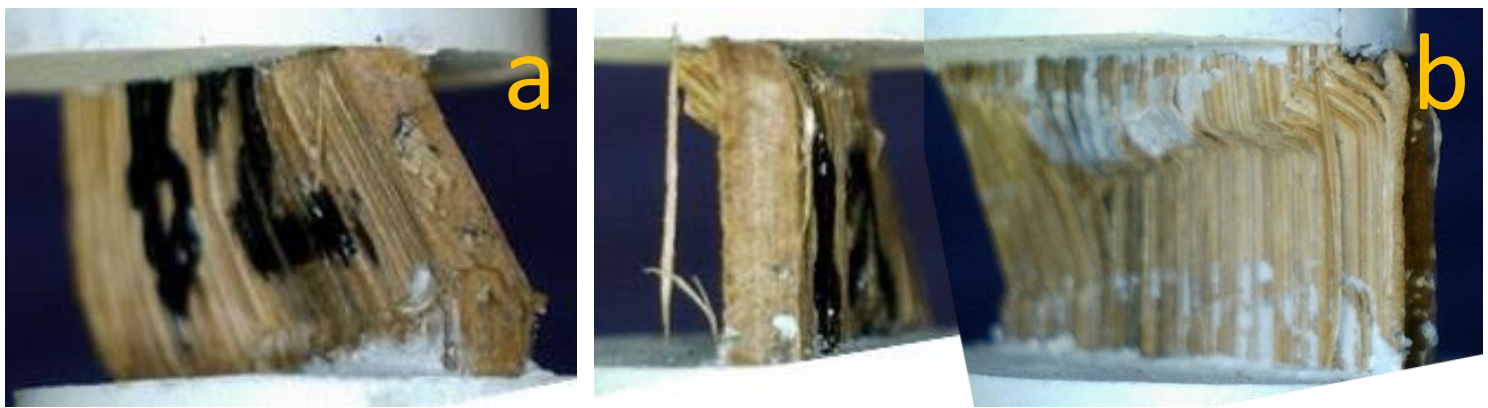

Figura 53: Detalhe de alguns dos modos de falha observados em corpos-de-prova da porção basal. a) Flexão e formação de rótulas plásticas junto aos engastes (Grupo 1); b) Ruptura à compressão com flambagem local das fibras e esmagamento (Grupo 4).

$\mathrm{Na}$ porção medial do colmo os tipos de ruptura são mais equilibrados (Figura 55), diminuindo consideravelmente a parcela de falhas do Grupo 1. As falhas do Grupo 5 representaram $44,4 \%$ do total, das quais $33,3 \%$ com a formação de rótulas plásticas, 22,2\% Grupo 1, 22,2\% Grupo 4 e 11,1\% Grupo 2. Nesta porção do colmo a largura e a altura efetiva dos corpos-de-prova tem a mesma ordem de grandeza.
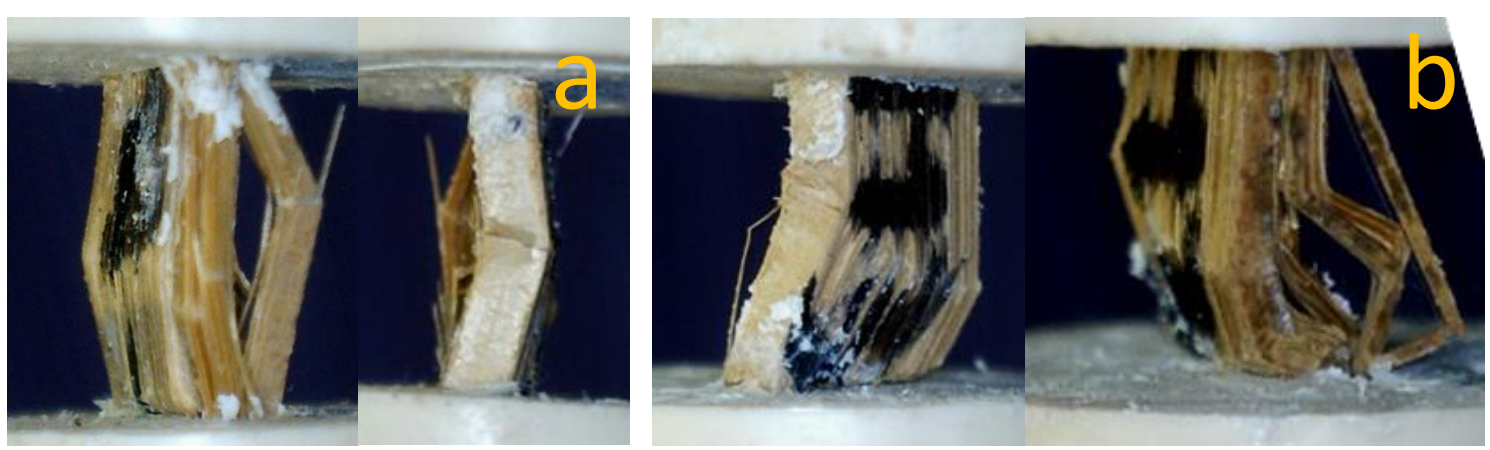

Figura 54: Detalhe de alguns dos modos de falha observados em corpos-de-prova da porção medial. a) Flambagem global, esmagamento local e cisalhamento tipo 1 (Grupo 3); b) Cisalhamento tipo 1, flexo-compressão, e esmagamento junto ao engaste inferior (Grupo 5) .

$\mathrm{Na}$ porção apical, a largura do corpo-de-prova é inferior à sua altura efetiva, aumentando a suscetibilidade à flambagem, de modo que o mecanismo de falha dominante é o enquadrado como Grupo 2 (Figura 55). Entretanto, a distribuição de tipologias de ruptura é bem variada. 42,86\% dos corpos-de-prova 
5.

romperam conforme o Grupo 2, 28,56\% como o Grupo 1, 14,29\% como grupo 4 e 14,29\% como Grupo 5.
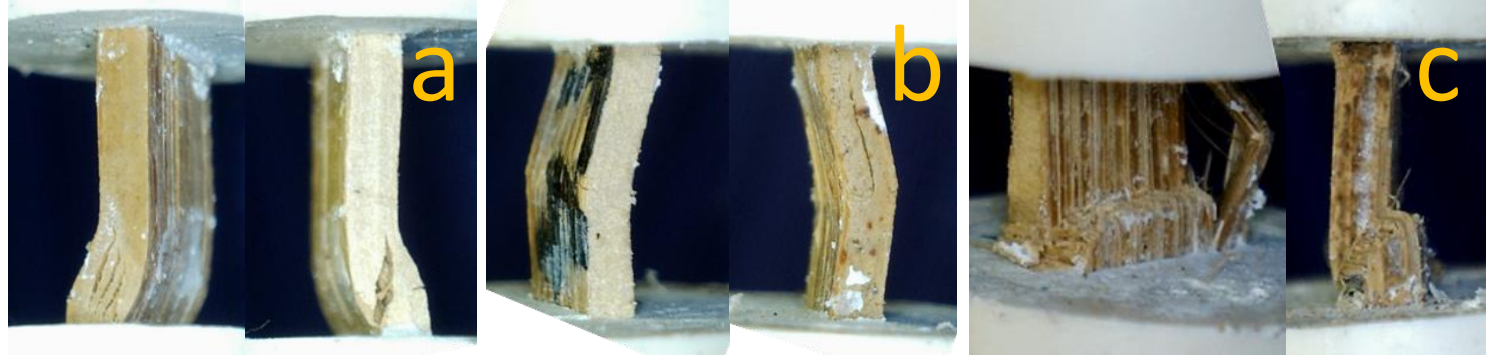

Figura 55: Detalhe de alguns dos modos de falha observados em corpos-de-prova da porção apical. a) Flambagem local e esmagamento junto ao engaste inferior (Grupo 4); b) Flambagem global (Grupo 2); c) Esmagamento local, associado a cisalhamento tipo 1 (Grupo 5).

A Figura 56 se refere à comparação: entre as médias das propriedades mecânicas e a posição no colmo (à esquerda); entre as médias das propriedades mecânicas e a fração volumétrica de fibras (à direita). Esta comparação não é precisa, uma vez que as amostras tomografadas provieram da colheita de 2012 e o material ensaiado mecanicamente da coheita de 2013, entretanto, procurou-se extrair os corpos-de-prova das mesmas porções do colmo, que as anteriormente analisadas.

Percebe-se que, apesar da maior fração volumétrica de fibras, a região apical não obteve os melhores resultados em termos de resistência (Figura 56b), embora tenha se deformado mais que a região medial (Figura 56f). Percebe-se entretanto que há uma clara influência da maior presença de fibras nas propriedades mecânicas ao se comparar os resultados das regiões medial e apical (bastante próximos) aos da região basal, cuja densidade de reforço é bastante reduzida. A rigidez, entretanto parece ser diretamente influenciada pela densidade de reforço (Figura 56d). Diante das observações, pode haver outras características intrínsecas ao material, que influenciem as propriedades mecânicas, além da fração volumétrica de fibras. Há que se verificar a fração volumétrica de vazios, as características geométricas microestruturais e a presença de inclusões orgânicas ou inorgânicas, investigando o grau de influência sobre a mecânica do bambu Dendrocalamus giganteus. 
5.
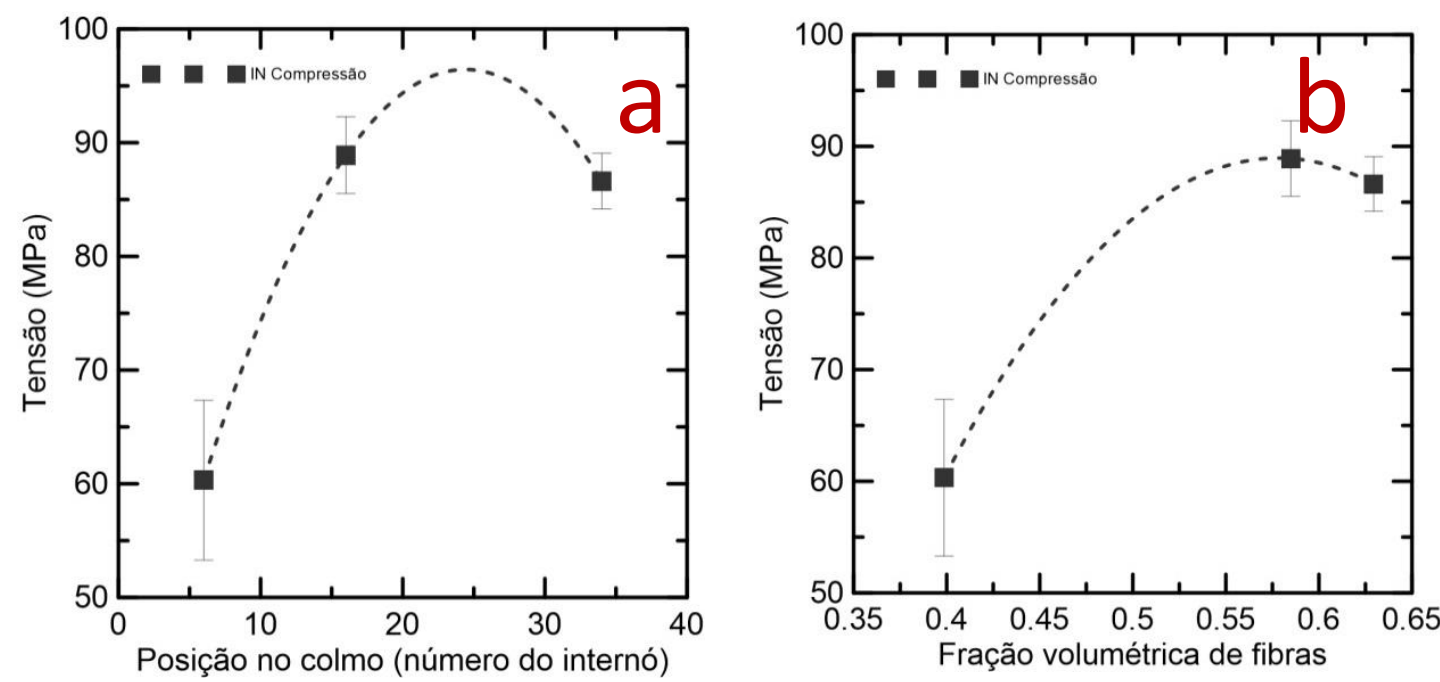

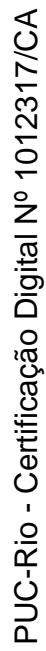
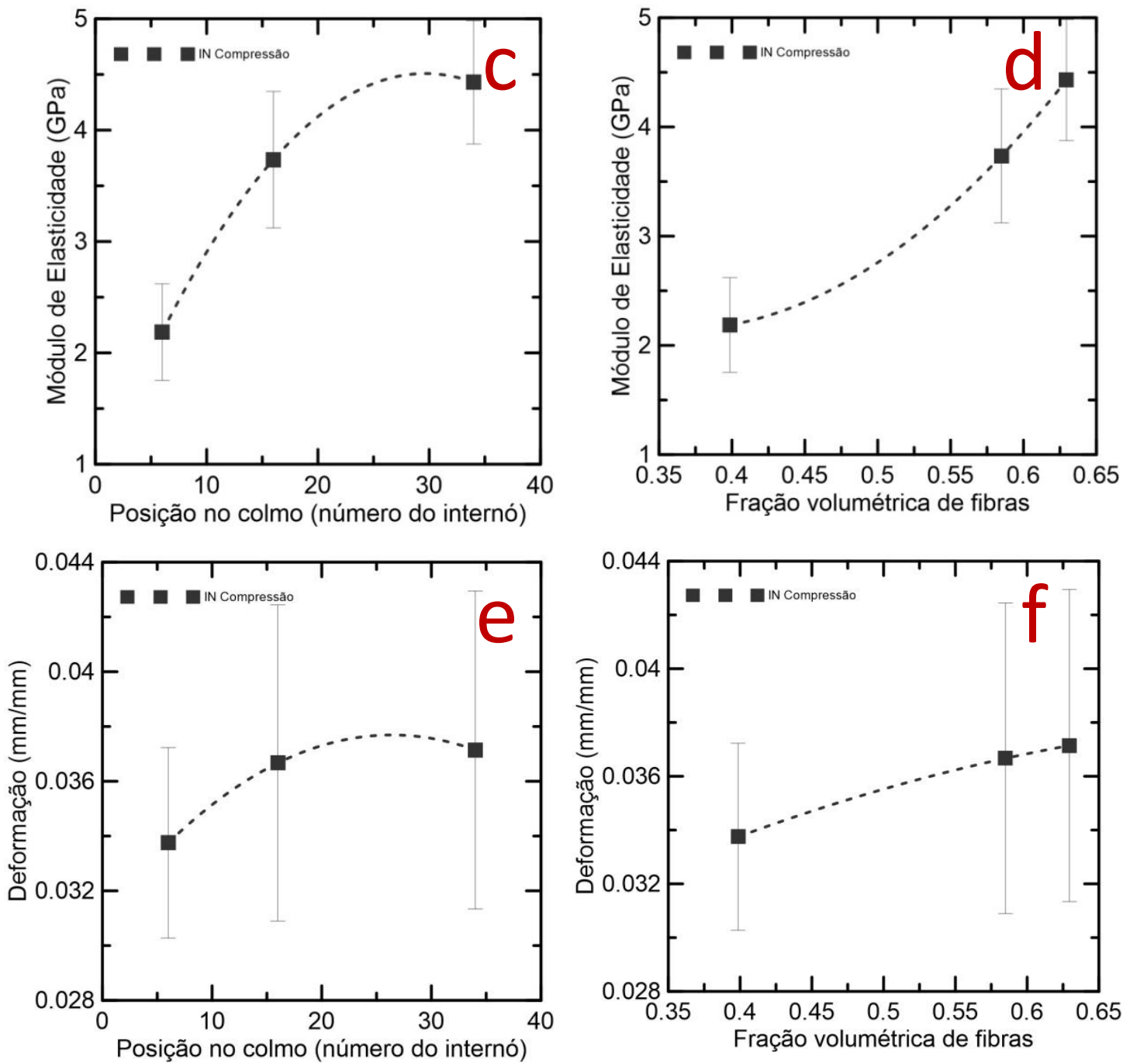

Figura 56: a) Tensão compressiva $\left(\sigma_{c}\right) \times$ Posição no colmo (pcolm); b) $\sigma_{c} \times$ Fração volumétrica de fibras $\left(v_{f}\right)$; c) Módulo de elasticidade $(E) \times$ pcolm; d) $E \times v_{f}$; e) Deformação limite $(\varepsilon) \times$ pcolm; f) $\varepsilon \times V_{f}$. 
5.

\subsubsection{Ensaios de cisalhamento}

Um sumário com informações gerais sobre as condições de ensaio e registros de tensão máxima, deslocamento global máximo e modulo de elasticidade é apresentado na Tabela 13 e as curvas tensão $x$ deformação são apresentadas na Figura 57. Os gráficos são traçados utilizando o deslocamento global da máquina, conforme relatado anteriormente para os demais ensaios. A nomenclatura dos copros-de-prova segue a lógica:

- S: refere-se a ensaios de cisalhamento (shear);

- B: refere-se à região basal;

- M: região medial;

- T: região apical (topo);

- O número ao final diferencia os corpos-de-prova de cada tipo.

Tabela 13: Lista de corpos-de-prova de cisalhamento com informações gerais sobre as condições de ensaio e registros de tensão máxima, deslocamento global máximo e modulo de elasticidade.

\begin{tabular}{|l|r|r|r|r|r|r|} 
corpos-de-prova & $\begin{array}{c}\text { área } \\
(\mathrm{mm} 2)\end{array}$ & $\begin{array}{c}\text { umidade } \\
\text { (\%) }\end{array}$ & $\begin{array}{c}\text { comprimento } \\
\text { inicial }(\mathrm{mm})\end{array}$ & \multicolumn{1}{c|}{$\tau_{\text {máx }}$} & \multicolumn{1}{c|}{$\gamma_{\text {máx }}$} & G \\
\hline SB1 & 845,70 & 13,00 & 48,80 & 5,64 & 0,0009 & 5,44 \\
\hline SB2 & 860,33 & 13,00 & 48,09 & 6,35 & 0,0009 & 4,19 \\
\hline SB3 & 827,38 & 13,00 & 48,02 & 6,57 & 0,0014 & 4,23 \\
\hline SM1 & 471,16 & 11,00 & 47,98 & 6,81 & 0,0001 & 5,63 \\
\hline SM2 & 377,68 & 13,00 & 47,21 & 6,55 & 0,0006 & 8,93 \\
\hline SM3 & 447,35 & 13,00 & 47,54 & 7,71 & 0,0021 & 5,86 \\
\hline ST1 & 327,79 & 11,00 & 49,07 & 5,30 & 0,0013 & 3,78 \\
\hline ST2 & 302,46 & 10,00 & 48,24 & 6,23 & 0,0008 & 3,74 \\
\hline ST3 & 298,78 & 11,00 & 48,19 & 5,86 & 0,0017 & 3,83 \\
\hline
\end{tabular}


5.

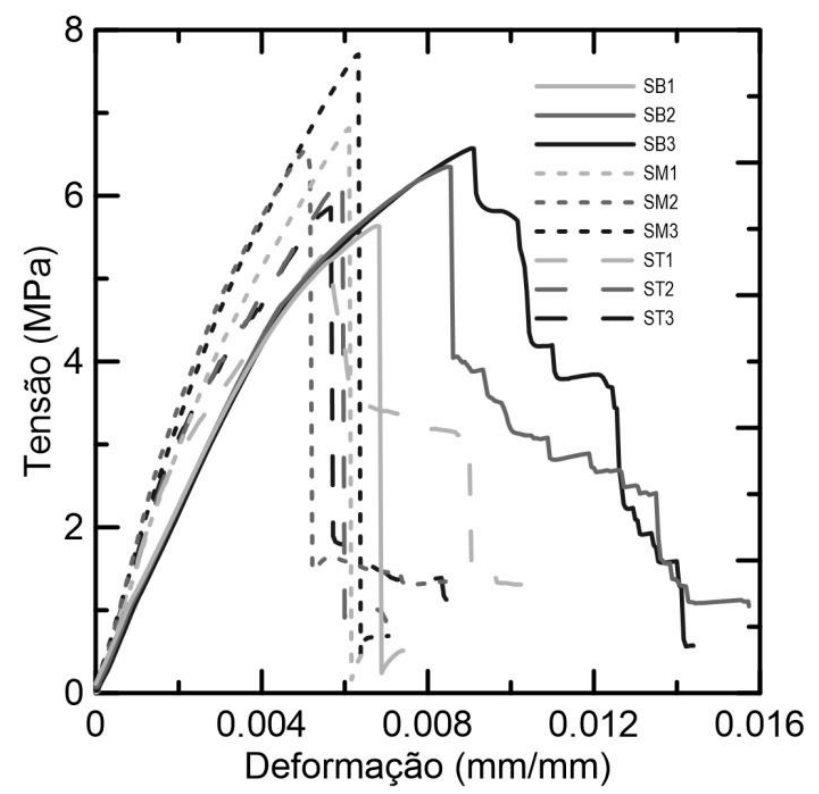

Figura 57: Curvas tensão $x$ deformação dos ensaios à cisalhamento para as porções basal (linha cheia), medial (tracejado curto) e apical (tracejado longo).

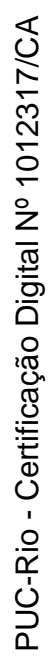

Um resumo com as médias e desvios padrão dos resultados dos ensaios estão consolidados abaixo na Tabela 14 e na Figura 58.

Tabela 14: Valores médios e desvios padrão associados das propriedades mecânicas à cisalhamento obtidas experimentalmente para as porções basal, medial e apical de regiões intermodais de bambu da espécie Dendrocalamus giganteus.

\begin{tabular}{|l|l|l|l|l|l|l|}
\cline { 2 - 7 } corpos-de-prova & $\boldsymbol{\tau}_{\text {med }}$ & $\boldsymbol{\tau}_{\text {std }}$ & $\boldsymbol{V}_{\text {med }}$ & $\boldsymbol{V}_{\text {std }}$ & $\mathbf{G}_{\text {med }}$ & $\mathbf{G}_{\text {std }}$ \\
\hline SB & 6,19 & 0,40 & 0,0010 & 0,0002 & 4,62 & 0,58 \\
\hline SM & 7,02 & 0,49 & 0,0009 & 0,0009 & 6,81 & 1,50 \\
\hline ST & 5,80 & 0,38 & 0,0013 & 0,0004 & 3,78 & 0,04 \\
\hline
\end{tabular}


5.

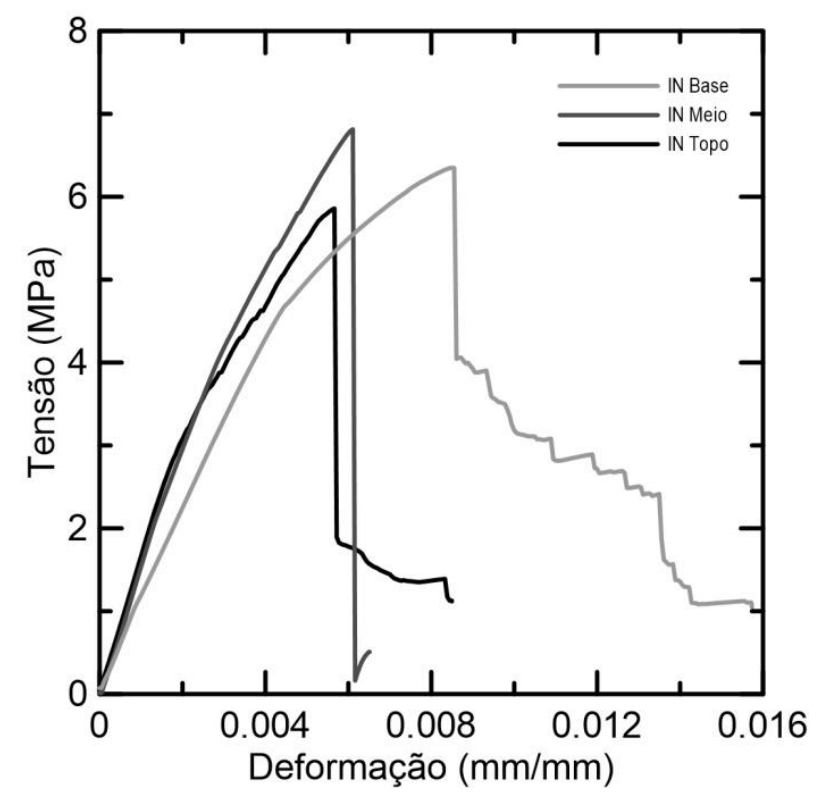

Figura 58: Curvas tensão $x$ deformação representativas de corpos-de-prova ensaiados, provenientes de regiões intermodais das porções basal, medial e apical do colmo.

A análise das curvas e valores não permite estabelecer relação entre a posição no colmo e qualquer tendência de variação regular de propriedades. Verifica-se que a porção medial apresenta maior rigidez e resistência, seguida da região basal e, surpreendentemente, apresentando a região apical com os números mais modestos. Percebe-se entretanto um desvio padrão bastante inferior na região apical, o que pode denotar maior irregularidade nas demais regiões.

O modo de ruptura é característico e não varia, apresentando a criação de uma superfície de cisalhamento bem marcada, com poucas fibras remanescentes na região de falha (Figura 59). Pela face interna percebe-se que há uma ruptura frágil da camada mais superficial, que tem estrutura diferente do restante do material, mas não influencia mecanicamente no seu comportamento (Figura 59c). 
5.

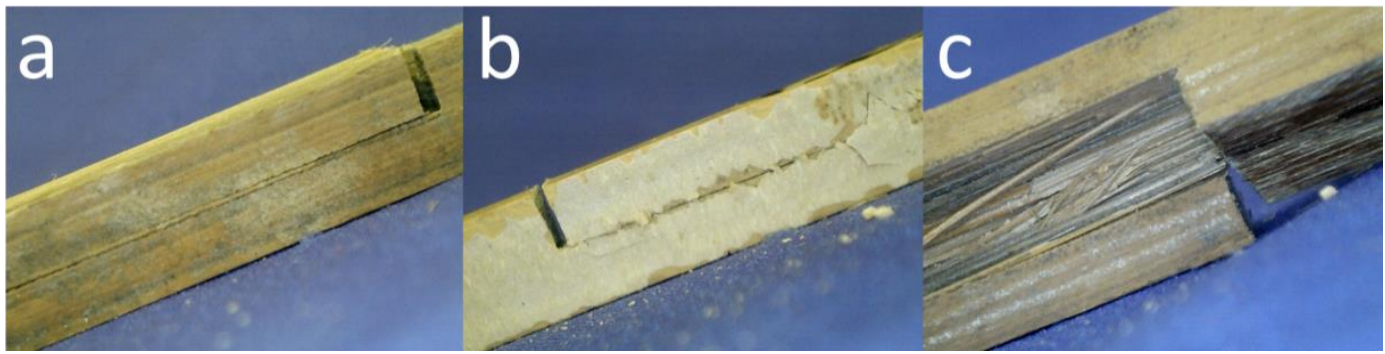

Figura 59: Modo de falha característico de todos os corpos-de-prova de cisalhamento ensaiados. a) Parte externa da parede: superfície de cisalhamento limpa e alinhada com as extremidades dos entalhes; b) Superfície de cisalhamento bem marcada. Fissuras na camada interna (inner layer); c) Poucas fibras remanescentes na seção cisalhada.

A Figura 60 se refere à comparação: entre as médias das propriedades mecânicas e a posição no colmo (à esquerda); entre as médias das propriedades mecânicas e a fração volumétrica de fibras (à direita). De modo similar ao descrito para os ensaios de compressão, as amostras tomografadas e o material ensaiado mecanicamente não são provenientes da mesma colheita, entretanto, no intuito de reduzir as discrepâncias, procurou-se extrair os corposde-prova de porções do colmo análogas às anteriormente analisadas. As informações consolidadas nos gráficos endossam a análise anterior e não contribuem para relacionar posição no colmo ou fração volumétrica de fibras com o comportamento ao cisalhamento, indicando que outras variáveis devem ser dominantes nesse caso. 
5.
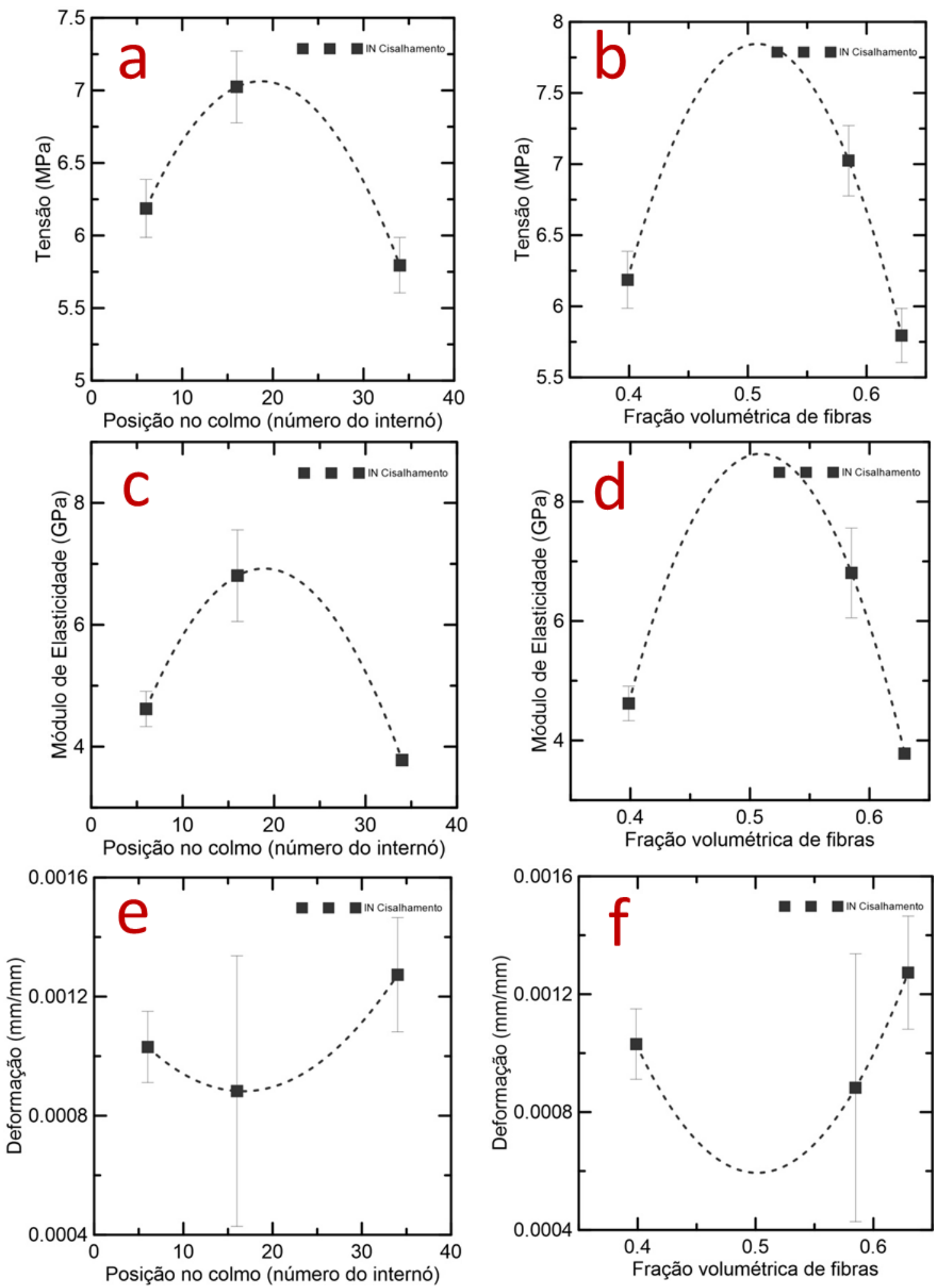

Figura 60: Tensão cisalhante $\left(\tau_{s}\right) \times$ Posição no colmo (pcolm); b) $\tau_{s} \times$ Fração volumétrica de fibras $\left(v_{f}\right)$; c) Módulo de cisalhamento (G) x pcolm; d) $G \times v_{f}$; e) Deformação limite $(\gamma) \times$ pcolm; $f) \gamma \times v_{f}$. 


\section{6. \\ Ensaios para a caracterização física e mecânica das lâminas}

\subsection{Introdução}

Após a realização dos ensaios de controle, que avaliam as propriedades do material bruto, passa-se à avaliação de lâminas obtidas de trechos específicos da espessura da parede e de diferentes porções do colmo.

Neste capítulo é proposto um conjunto de ensaios mecânicos específico para lâminas isoladas de bambu para a obtenção das relações constitutivas e constantes do material conforme será utilizado na prática em compósitos estruturais laminados. Para tanto são conduzidos ensaios que procuram submeter o material a tensões puras de tração, compressão e cisalhamento, bem como ensaios que o submetem à flexão, estado de tensões composto ao qual, em geral, laminados são submetidos. São avaliadas quatro seções provenientes da porção basal do colmo, três da porção medial e duas da apical, totalizando 9 variações para cada ensaio. Em adição, ensaios de cisalhamento na linha da colagem são conduzidos para determinar a resistência do adesivo e/ou o modo de falha característico na interface entre o bambu e o poliuretano, fundamental para a elaboração dos compósitos laminados.

\subsection{Ensaios de variação de umidade}

O objetivo destes ensaios é medir a variação dimensional e de densidade do material sob diferentes condições de umidade e comparar a sua capacidade de absorção à sua fração volumétrica de vazios, procurando estabelecer um paralelo. Para tanto os corpos-de-prova secos ao ar são pesados em uma balança eletrônica Shimadzu AUY220, com precisão de 0,01 g e tem suas medidas de altura, largura e espessura tomadas por um paquímetro. Este procedimento se repete periodicamente ao longo de todo o ensaio de variação de umidade. De início os corpos-de-prova são submetidos a um processo de secagem suave à temperatura de $50^{\circ} \mathrm{C}$ em uma estufa para esterilização da marca Famo, sendo periodicamente pesados e medidos até atingir um patamar. 
6.

Este processo serve para homogeneizar a umidade inicial dos corpos-de-prova. Na sequência são imersos em água destilada até a saturação, caracterizando o peso saturado $\left(P_{n}\right)$. Finalmente são secos novamente, passando por uma primeira fase ao ar e uma segunda em estufa à $150^{\circ} \mathrm{C}$ até a estabilização, caracterizando o peso seco $\left(P_{s}\right)$. Os corpos-de-prova têm originalmente cerca de $15 \mathrm{~mm} \times 15 \mathrm{~mm} \times 2 \mathrm{~mm}$ (Figura 61), tendo sido obtidos a partir dos internós 6, 16 e 33, do colmo de Dendrocalamus giganteus proveniente da colheita de 2013.

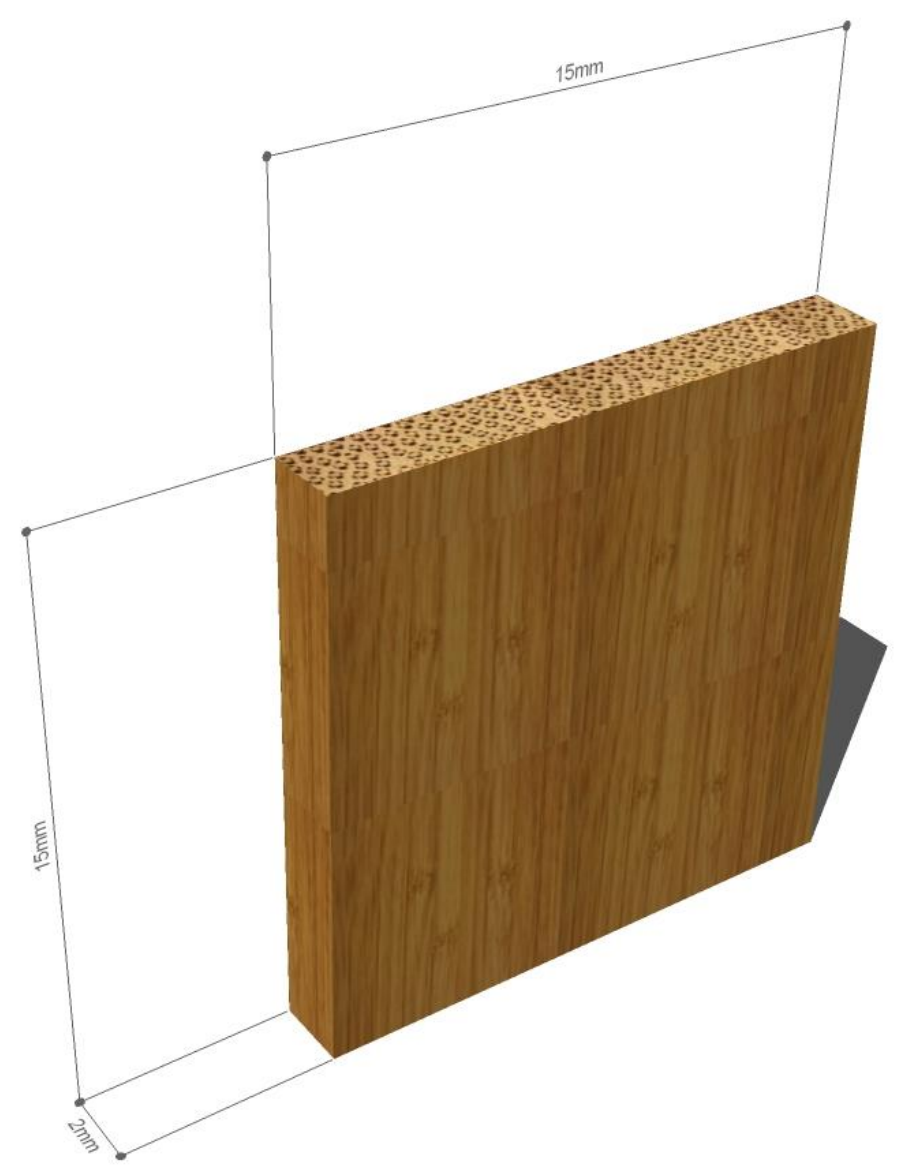

Figura 61: Corpo-de-prova para os ensaios de variação de umidade e variação dimensional.

O processo de confecção dos corpos-de-prova segue a descrição de obtenção das lâminas detalhada no Capítulo 3.1.2, com a diferença de que, no ítem 4 a dimensão de corte é de $15 \mathrm{~mm}$. Uma vez obtidas as lâminas com 15 $\mathrm{mm}$ de largura, provenientes das diferentes porções de colmo e regiões da parede, estas são cortadas transversalmente com $15 \mathrm{~mm}$. 
6.

\subsubsection{Ensaio de Absorção}

A quantidade de água destilada absorvida é obtida, em porcentagem, em relação ao peso seco a partir da Eq. 6:

$A=\left(\frac{P_{n}-P_{S}}{P_{S}}\right) \times 100$

Eq. 6

A: Porcentagem de água absorvida em relação ao peso seco (\%)

$P_{n}:$ Peso saturado $(g)$

$P_{s}:$ Peso seco $(g)$

O peso de água na condição saturada pode ser obtido subtraindo o peso seco do peso saturado (Eq. 7):

$P_{a_{c s}}=P_{n}-P_{s}$

Eq. 7

$P_{a_{c s}}:$ Peso de água $(g)$

$P_{n}:$ Peso saturado $(g)$

$P_{s}:$ Peso seco $(g)$

A partir daí pode-se calcular o volume de água em cada amostra, dividindo o peso de água pela densidade da água (Eq. 8):

$V_{a_{c s}}=\frac{P_{a_{c s}}}{\rho_{a}}$

$V_{a_{c s}}:$ Volume de água na condição saturada $\left(\mathrm{cm}^{3}\right)$

$P_{a_{c s}}:$ Peso de água $(g)$

$\rho_{a}:$ Densidade de água $\left(\mathrm{g} / \mathrm{cm}^{3}\right)$

Uma estimativa da fração volumétrica total de vazios na condição saturada, incluindo vasos condutores, células do parênquima, microvazios como os lúmens e os canais de comunicação entre as pardes celulares, fissuras e outros vazios relativos à higroscopicidade da celulose e da lignina pode ser obtida a partir da Eq. 9:

$v_{v_{c s}}=\left(V_{a} / V_{c S}\right) \times 100$

Eq. 9

$v_{v_{c s}}:$ Fração volumétrica de vazios na condição saturada (\%)

$V_{a}:$ Volume de água $\left(\mathrm{cm}^{3}\right)$

$V_{c s}:$ Volume da amostra na condição saturada $\left(\mathrm{cm}^{3}\right)$

A partir da estimativa de fração volumétrica de vazios na condiçao saturada é possível obter o volume de sólidos, incluindo fibras, matriz, inclusões orgânicas, inorgânicas e resíduos metabólicos, por meio da Eq. 10. Importante ressaltar que, em termos práticos, este volume será invariável, independente da condição de saturação: 
6.

$V_{s}=V_{c s} \times\left(\frac{100-v_{a_{c s}}}{100}\right)$

Eq. 10

$V_{S}:$ Volume de sólidos $\left(\mathrm{cm}^{3}\right)$

$V_{c s}:$ Volume da amostra na condição saturada $\left(\mathrm{cm}^{3}\right)$

$v_{a_{c s}}:$ Fração volumétrica de água na condição saturada (\%)

Com o volume de sólidos pode-se obter o volume de vazios na condição inicial da amostra, por meio da Eq. 11:

$V_{v_{c i}}=V_{c i}-V_{s}$

Eq. 11

$V_{v_{c i}}:$ Volume de vazios na condição inicial $\left(\mathrm{cm}^{3}\right)$

$V_{c i}$ : volume da amostra na condição inicial $\left(\mathrm{cm}^{3}\right)$

$V_{s}:$ Volume de sólidos $\left(\mathrm{cm}^{3}\right)$

Então se pode estimar a fração volumétrica de vazios na condição inicial da amostra, por meio da Eq. 12:

$v_{v_{c i}}=\left(\frac{V_{v_{c i}}}{V_{c i}}\right) \times 100$

Eq. 12

$v_{v_{c i}}:$ Fração volumétrica de vazios na condição inicial (\%)

$V_{v_{c i}}:$ Volume vazios na condição inicial $\left(\mathrm{cm}^{3}\right)$

$V_{c i}:$ Volume da amostra na condiç̧ão inicial $\left(\mathrm{cm}^{3}\right)$

Esta é uma formulação proposta por este trabalho e, na apresentação dos seus resultados, será confrontada com os dados obtidos a partir das quantificações de frações volumétricas obtidas por meio de microtomografias, expostas no Capítulo 4.4.

\subsubsection{Peso específico}

O Peso específico é obtido a partir da divisão do peso seco pelo volume inicial (eq. 13).

$\gamma=\frac{P_{s}}{V_{i}}$

Eq. 13

$\gamma$ : Peso específico $\left(\mathrm{g} / \mathrm{cm}^{3}\right)$

Ps: Peso seco ( $g$ )

$V_{i}:$ volume inicial $\left(\mathrm{cm}^{3}\right)$ 
6.

\subsubsection{Estabilidade dimensional}

Para calcular a estabilidade dimensional do material, as dimensões tangencial, longitudinal e radial de cada corpo-de-prova são tomadas periodicamente durante as variações de condições de umidade a que são submetidos. São consideradas as medidas iniciais e as medidas em condição saturada para verificar a variação em cada uma das dimensões e no volume dos corpos-de-prova, conforme expresso nas equações abaixo:

Variação tangencial: largura do corpo-de-prova

$V_{t}=\left(\frac{t_{n}-t_{i}}{t_{i}}\right) \times 100$

$V_{t}$ : Variação tangencial (\%)

$t_{n}$ : largura em condição saturada $(\mathrm{mm})$

$t_{i}$ : largura inicial $(\mathrm{mm})$

Variação longitudinal: altura do corpo-de-prova

$V_{l}=\left(\frac{l_{n}-l_{i}}{l_{i}}\right) \times 100$

$V_{l}:$ Variação longitudinal (\%)

$l_{n}$ : altura em condição saturada $(\mathrm{mm})$

$l_{i}$ : altura inicial $(\mathrm{mm})$

Variação radial: espessura do corpo-de-prova

$V_{r}=\left(\frac{r_{n}-r_{i}}{r_{i}}\right) \times 100$

Eq. $14 \mathrm{c}$

$V_{r}:$ Variação radial (\%)

$r_{n}$ : espessura em condição saturada $(\mathrm{mm})$

$r_{i}$ : espessura inicial $(\mathrm{mm})$

\subsection{Ensaios de tração longitudinal às fibras}

De modo similar à sugestão para os ensaios de controle de tração sugerese adotar um corpo-de-prova derivado da norma ASTM D3039 [85] para propriedades mecânicas à tração de materiais compósitos com matriz polimérica, composto por uma lâmina simples de bambu com cerca de $2 \mathrm{~mm}$ de espessura, dotado ou não de reforços de madeira ou alumínio na região de contato com as garras (Figura 62). A diferença, no caso, se dá em relação à orientação da obtenção e confecção das lâminas. 
6.

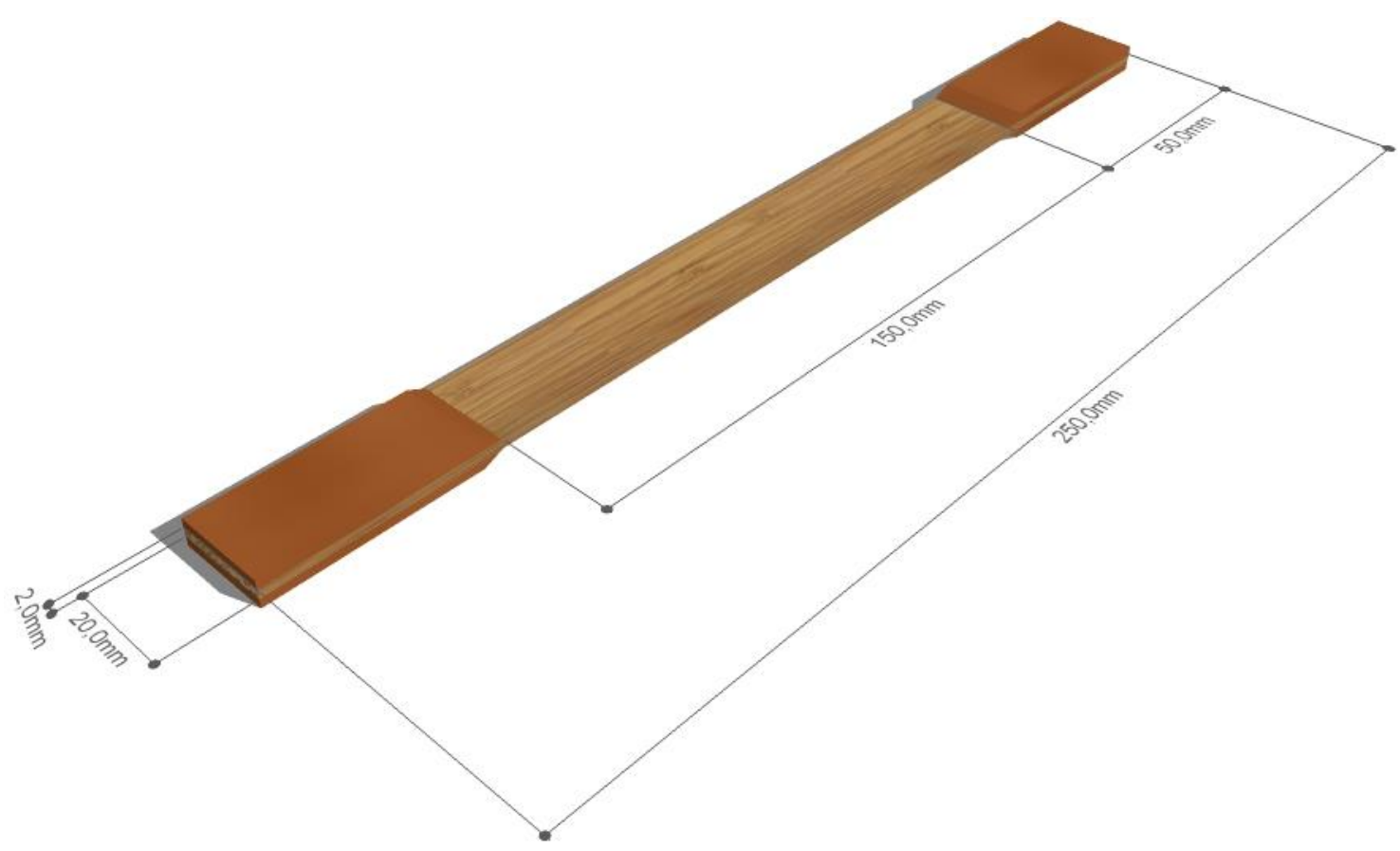

Figura 62: Corpo-de-prova de tração simples baseado nas recomendações da norma ASTM D3039 [85], elaborado com seções circunferenciais de diferentes pontos da parede do colmo.

Os corpos-de-prova foram obtidos a partir dos internós $6,7,15,16,17,31$, 32 e 33, do colmo de Dendrocalamus giganteus proveniente da colheita de 2013. A metodologia de confecção das lâminas está descrita detalhadamente no Capítulo 3.1.2. Após o procedimento descrito efetua-se o corte transversal das lâminas com a medida desejada, no caso $250 \mathrm{~mm}$.

Os ensaios de tração são conduzidos, de um modo geral, da mesma maneira descrita para os ensaios de controle anteriormente propostos, à exceção da medição das deformações dos corpos-de-prova, que, no caso, utiliza clip-gages Shimadzu SG 25-25 posicionados no seu terço central. A Figura 34a apresenta o esquema de ensaio. Antes de conduzir os ensaios, a umidade de cada corpo-de-prova é verificada utilizando um medidor de umidade para madeiras.

Foram ensaiados 5 corpos-de-prova para cada variável em cada região internodal analisada, perfazendo um total de 45 ensaios:

- Porção basal: 4 regiões da parede do colmo, respectivamente interna, meso-interna, meso-externa e externa;

- Porção medial: 3 regiões, respectivamente interna, medial e externa;

- Porção apical: 2 regiões, interna e externa. 
6.

\subsection{Ensaios de compressão paralela às fibras}

De modo similar ao apresentado para os ensaios à compressão de controle, propõe-se a confecção de um corpo-de-prova alternativo, com dimensões de seção e comprimento da região ensaiada constantes nas definições da norma, dotado de enrijecedores/estabilizadores nas extremidades, visando a diminuir os efeitos de rotação. Os enrijecedores foram, no entatno, aperfeiçoados, de modo a facilitar o processo de elaboração dos corpos-deprova, evitar desalinhamentos e falta de paralelismo entrea base e o topo do corpo-de-prova e permitir a aferição da umidade, por meio de um medidor de umidade para madeiras. Na nova versão passam a ser confeccionados a partir de uma cantoneira de alumínio com parafusos e porcas como fixadores, de modo que são afixados ao corpo-de-prova no momento do ensaio. O corpo-deprova é uma lâmina de bambu com seção de $10 \mathrm{~mm}$ de largura (eixo tangencial) por $2 \mathrm{~mm}$ de espessura (eixo radial), com $30 \mathrm{~mm}$ de comprimento, dos quais o terço central, de $10 \mathrm{~mm}$, representa a região ensaiada (Figura 63).
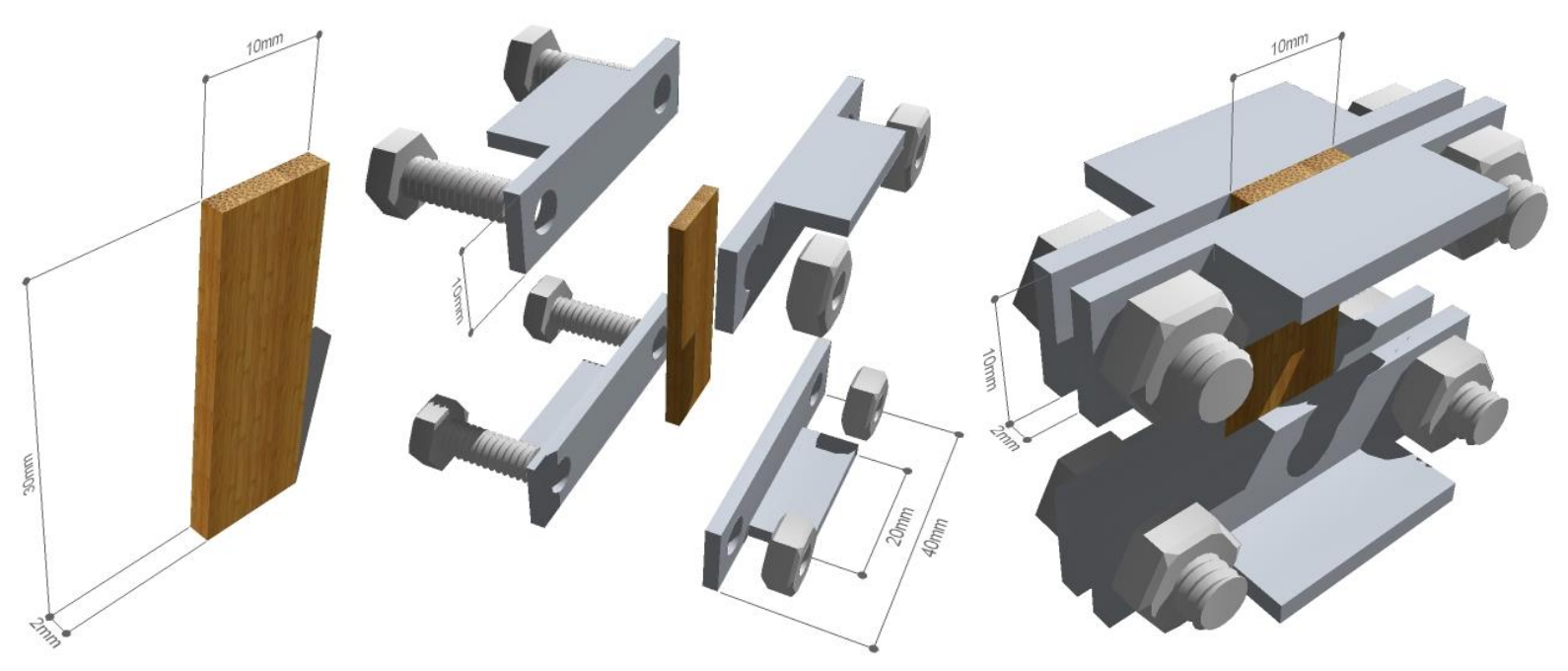

Figura 63: Corpo-de-prova de compressão adaptado a partir do recomendado pela Norma ASTM D3410 [87], elaborado com seções circunferenciais de diferentes pontos da parede do colmo; esquema de montagem dos enrijecedores e conjunto montado.

Os corpos-de-prova foram confeccionados a partir dos internós 7, 17 e 32, do colmo de Dendrocalamus giganteus proveniente da colheita de 2013, seguindo o processo descrito no Capítulo 3.1.2, com a diferença de que, no ítem 4 a dimensão de corte é de $10 \mathrm{~mm}$. Na sequência foi utilizada uma serra de esquadrias para realizar os cortes transversais a cada $30 \mathrm{~mm}$. 
6.

Os ensaios são conduzidos da mesma forma descrita para os de controle à compressão descrito no capítulo anterior. Foram ensaiados 5 corpos-de-prova para cada variável em cada região internodal analisada, totalizando 45 ensaios, com distribuição idêntica à descrita nos ensaios de tração deste capítulo. A Figura 64 ilustra o esquema do ensaio à compressão conduzido com a nova configuração dos enrijecedores do corpo-de-prova.

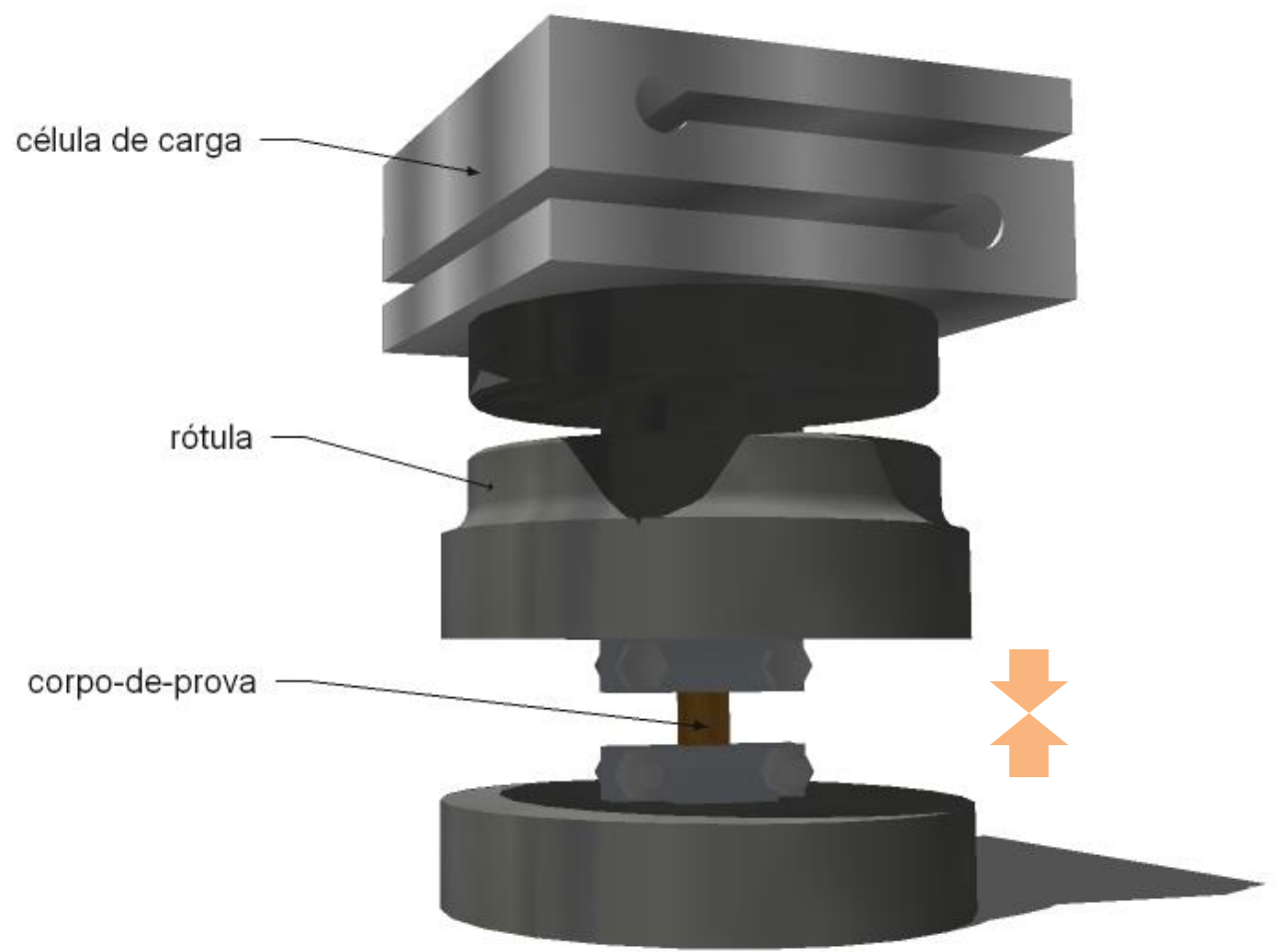

Figura 64: Setup de ensaio de compressão simples proposto para as lâminas.

\subsection{Ensaios de cisalhamento (compressão 45)}

Para os ensaios de cisalhamento propões-se um corpo de prova laminar com orientação de fibras planar de 45ํㅜㄹ cujas medidas são $10 \mathrm{~mm} \times 10 \mathrm{~mm} \times 2$ $\mathrm{mm}$, sendo a última referente ao eixo radial do material (Figura 65). Propõe-se também um suporte posicionador/estabilizador específico para a condução deste ensaio. O suporte original foi elaborado em madeira de alta densidade Cumaru, mas o ideal é que seja confeccionado em metal (Figura 65). Trata-se de um par de conjuntos, cada qual composto por dois blocos, que são fixados entre si por um parafuso. Em um dos blocos há um rebaixo, que tem a função de mordente para o corpo-de-prova. No seu par há um anteparo com dupla função: $1^{\text {a }}$ servir de guia de alinhamento entre os blocos, permitindo encaixe adequado e 
6.

evitando rotações entre os blocos; $2^{\underline{a}}$ servir de batente para o corpo-de-prova, evitando o seu deslizamento. Em conjunto, possuem um chanfro a $45^{\circ}$ alinhado com a área de cisalhamento .

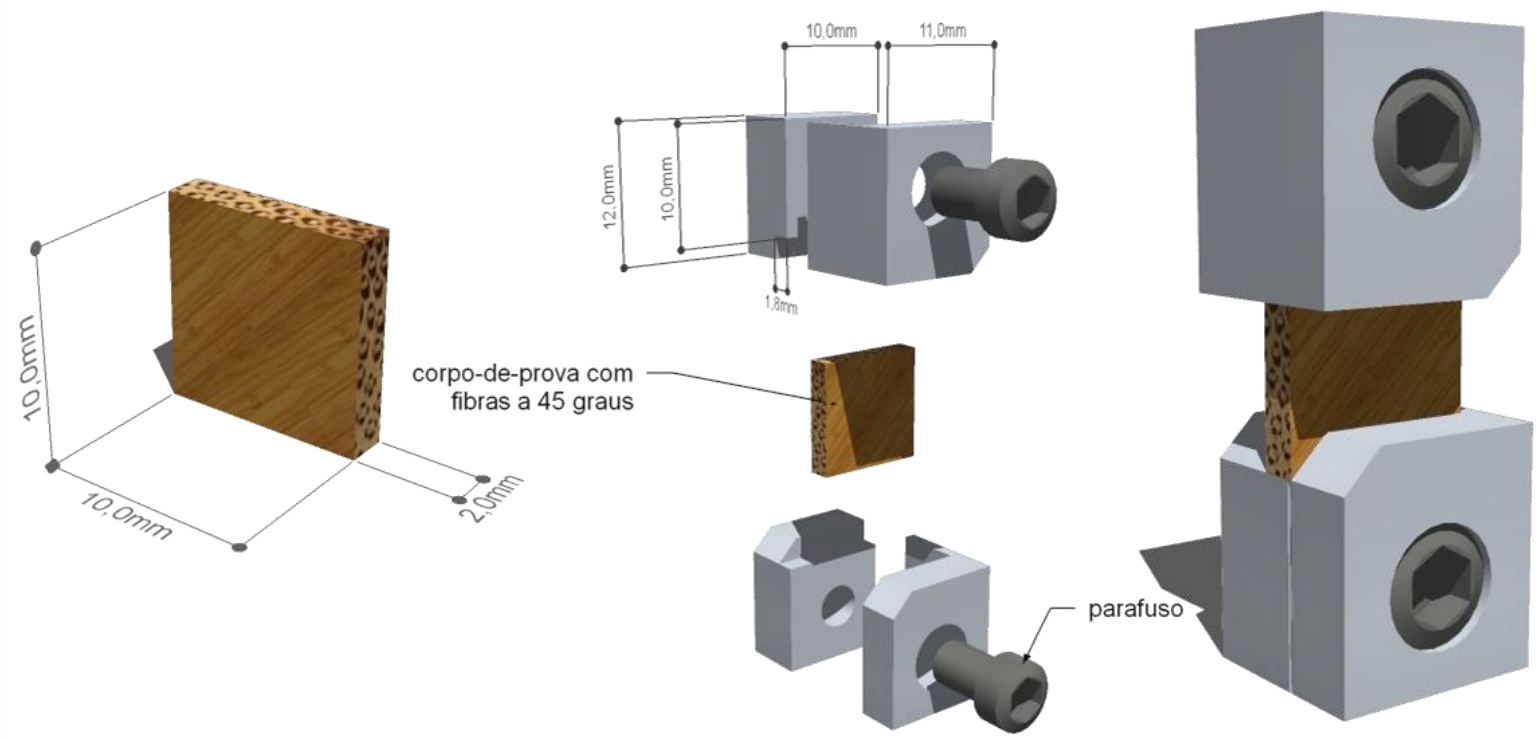

Figura 65: Corpo-de-prova de cisalhamento, elaborado com seções circunferenciais de diferentes pontos da parede do colmo; esquema de montagem com os mordentes/estabilizadores e conjunto montado.

Os corpos-de-prova foram confeccionados a partir dos internós 7, 17 e 32, do colmo de Dendrocalamus giganteus proveniente da colheita de 2013, seguindo o processo de laminação descrito na Seção 3.1.2. Na sequência foi confeccionado um gabarito simples para realizar os cortes a $45^{\circ}$ com um arco de serra para uso manual. A priori tentou-se utilizar uma serra de esquadrias de bancada, mas, dadas as dimensões dos corpos-de-prova, o processo mostrouse arriscado e grosseiro demais para o trato com o material nessas condições.

A proposta consiste em conduzir um ensaio de compressão simples, promovendo o deslizamento na diagonal central do corpo-de-prova. Os ensaios são controlados por deslocamento a uma taxa de $1 \mathrm{~mm} / \mathrm{min}$ utilizando software integrante da máquina. A deformação dos corpos-de-prova é obtida utilizando o deslocamento global da máquina. As tensões são obtidas por meio do carregamento, registrado pela célula de carga de 100 kN da máquina, dividido pela área de cisalhamento ensaiada (plano radial $x$ longitudinal, na diagonal maior do corpo-de-prova). O ambiente é condicionado, com temperatura de $21^{\circ} \mathrm{C}$. Durante os ensaios, uma máquina fotográfica procede automaticamente à aquisição de imagens a intervalos regulares de $10 \mathrm{~s}$. A umidade superficial não 
6.

pode ser obtida, dadas as dimensões dos corpos-de-prova. Foram ensaiados 5 corpos-de-prova para cada variável em cada região internodal analisada, perfazendo um total de 45 ensaios, com distribuição idêntica à descrita anteriormente para os ensaios de tração e compressão. A Figura 66 ilustra o esquema do ensaio à cisalhamento conduzido com o corpo-de-prova fixado aos suportes.

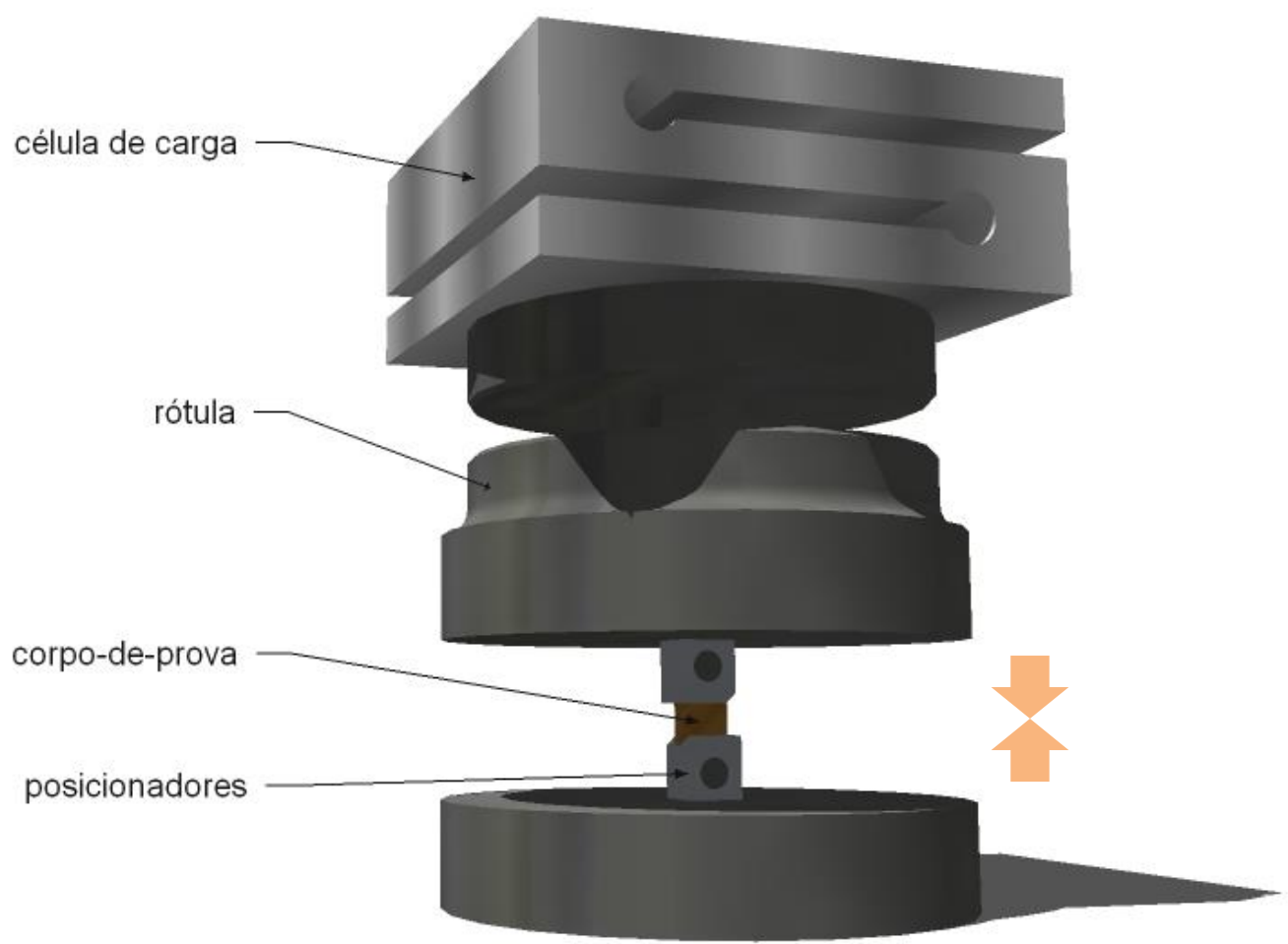

Figura 66: Setup de ensaio de cisalhamento simples.

\subsection{Ensaios de flexão 3 pontos}

O corpo-de-prova elaborado para os ensaios de flexão 3 pontos consiste de uma lâmina com seção de $20 \mathrm{~mm} \times 2$ mm e comprimento de 200 mm (Figura $67)$.

Os corpos-de-prova foram obtidos a partir dos internós 7, 8, 15, 16, 17, 31 e 32 do colmo de Dendrocalamus giganteus proveniente da colheita de 2013. A metodologia de confecção das lâminas está descrita detalhadamente no Capítulo 3.1.2. Após o procedimento descrito efetua-se o corte transversal das lâminas com a medida desejada, no caso $200 \mathrm{~mm}$. 
6.

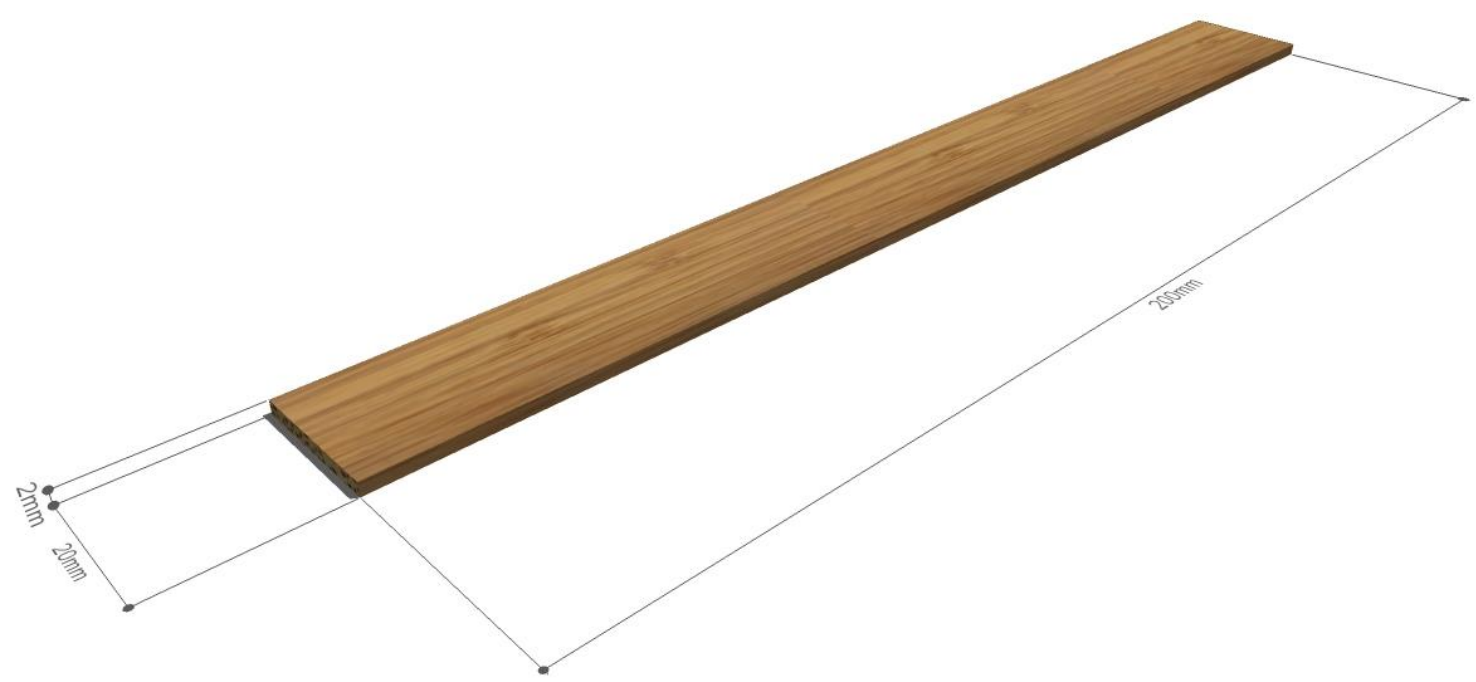

Figura 67: Corpo-de-prova de flexão, elaborado com seções circunferenciais de diferentes pontos da parede do colmo.

Os ensaios de flexão são conduzidos utilizando um setup próprio da máquina, composto de três roletes, dos quais dois configuram os apoios e distam $160 \mathrm{~mm}$ um do outro e o terceiro aplica o carregamento no centro do vão. Os ensaios são controlados por deslocamento a uma taxa de $5 \mathrm{~mm} / \mathrm{min}$ utilizando software integrante da máquina. Um LVDT acoplado ao setup é utilzado para obter os deslocamentos no centro do vão, enquanto que as tensões são calculadas a partir do carregamento, registrado pela célula de carga de 100 kN da máquina. Antes de conduzir os ensaios, a umidade de cada corpo-de-prova é verificada utilizando um medidor de umidade para madeiras. $\mathrm{O}$ ambiente é condicionado, com temperatura de $21^{\circ} \mathrm{C}$. Foram ensaiados 5 corposde-prova para cada variável em cada região internodal analisada, totalizando um total de 45 ensaios, com distribuição idêntica à descrita para os ensaios anteriores. Durante os ensaios, uma máquina fotográfica procede automaticamente à aquisição de imagens a intervalos regulares de $10 \mathrm{~s}$. A Figura 68 apresenta o esquema de ensaio. 
6.

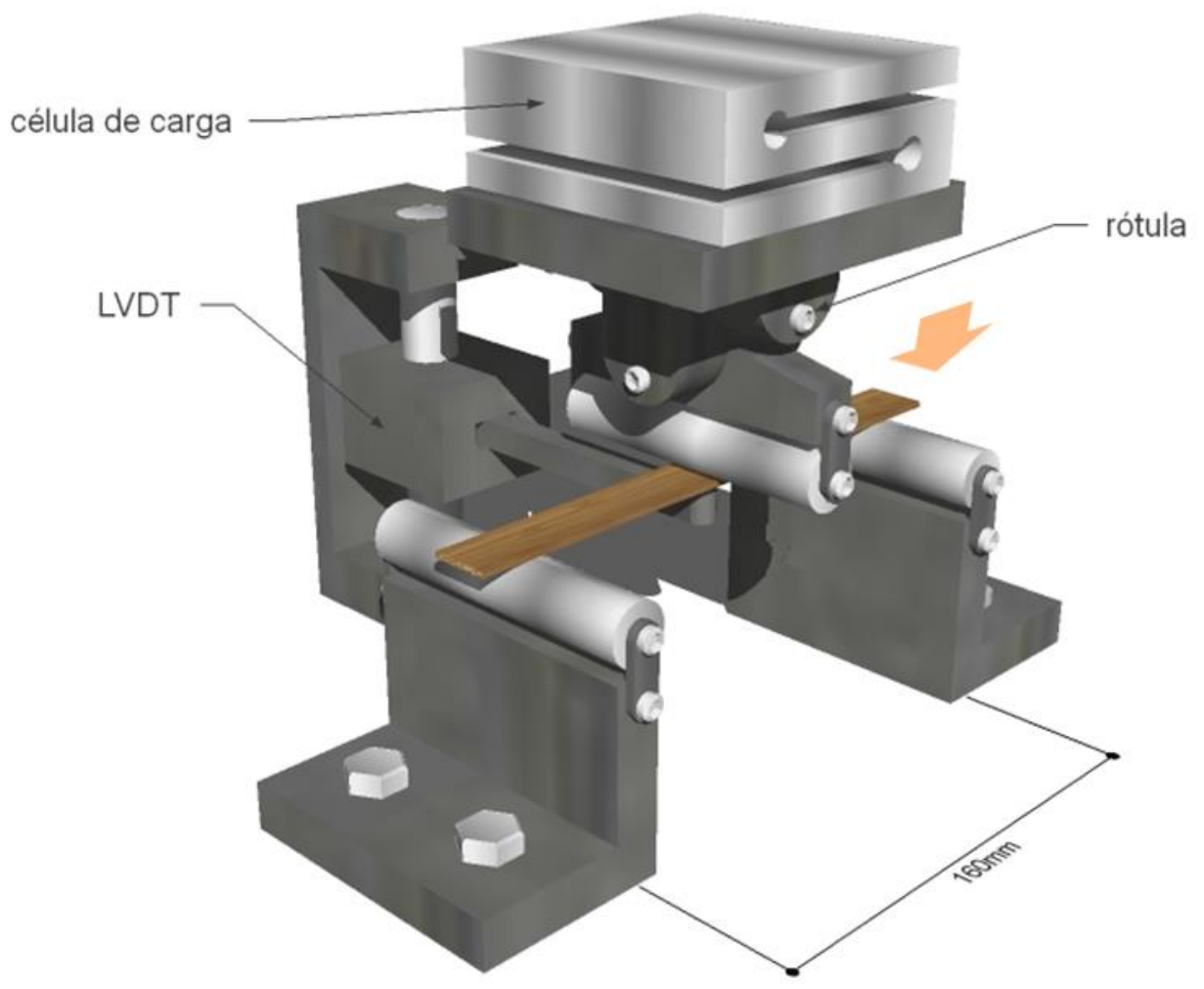

Figura 68: Setup de ensaio de flexão 3 pontos.

Por tratar-se de um ensaio com grandes deslocamentos, a flecha só é medida pelo LVDT até o seu limite $(10 \mathrm{~mm})$. Neste momento o ensaio é pausado e o LVDT é dissociado fisicamente do setup. Em todo o ensaio o deslocamento global é obtido pela própria MUE.

Dado o baixo carregamento, a resistência do LVDT originalmente aparece nas curvas, portanto os dados foram tratados, de modo a excluir tais influências externas.

\subsection{Ensaios de cisalhamento do adesivo}

Os corpos-de-prova para cisalhamento do adesivo são baseados na norma ASTM D-3163 [91], sendo compostos por duas lâminas de bambu com 102 mm de comprimento e seção de $20 \mathrm{~mm} \times 2 \mathrm{~mm}$, coladas entre si com uma sobreposição linear de $13 \mathrm{~mm}\left(260 \mathrm{~mm}^{2}\right)$, com um comprimento total de $191 \mathrm{~mm}$ (Figura 69). No caso, a origem das lâminas não foi controlada, uma vez que o intuito é avaliar a resistência e a rigidez do adesivo. O processo de laminação é o mesmo descrito para os demais ensaios, seguido do corte transversal aos 102 $\mathrm{mm}$. A mistura do poliuretano está descrita no capítulo 3.1.3. 
6.

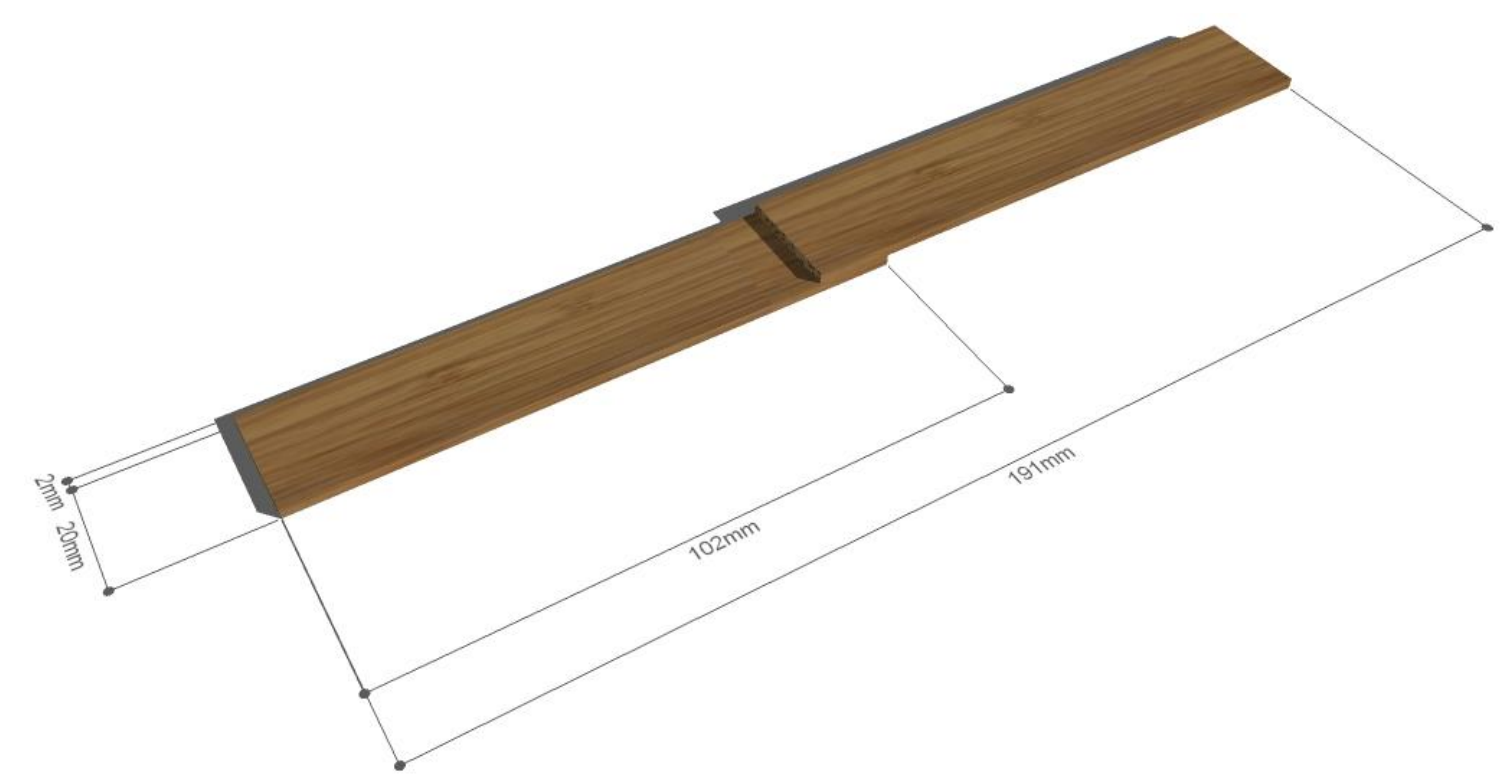

Figura 69: Corpo-de-prova para a verificação do cisalhamento na linha da colagem, baseado na norma ASTM D-3163 [91].

Os ensaios são controlados por deslocamento a uma taxa de deslocamento de $1 \mathrm{~mm} / \mathrm{min}$, utilizando o software integrante da máquina. Para medir a deformação dos corpos-de-prova, são utilizados clip-gages Shimadzu SG 50-50 posicionados no seu terço central. As tensões são obtidas por meio do carregamento, registrado pela célula de carga de $100 \mathrm{kN}$ da máquina, dividido pela área da seção ensaiada. $\mathrm{O}$ ambiente é condicionado, com temperatura de $21^{\circ} \mathrm{C}$. Durante os ensaios, uma máquina fotográfica procede automaticamente à aquisição de imagens a cada 10 segundos. O esquema de ensaio é ilustrado na Figura 70. 
6.

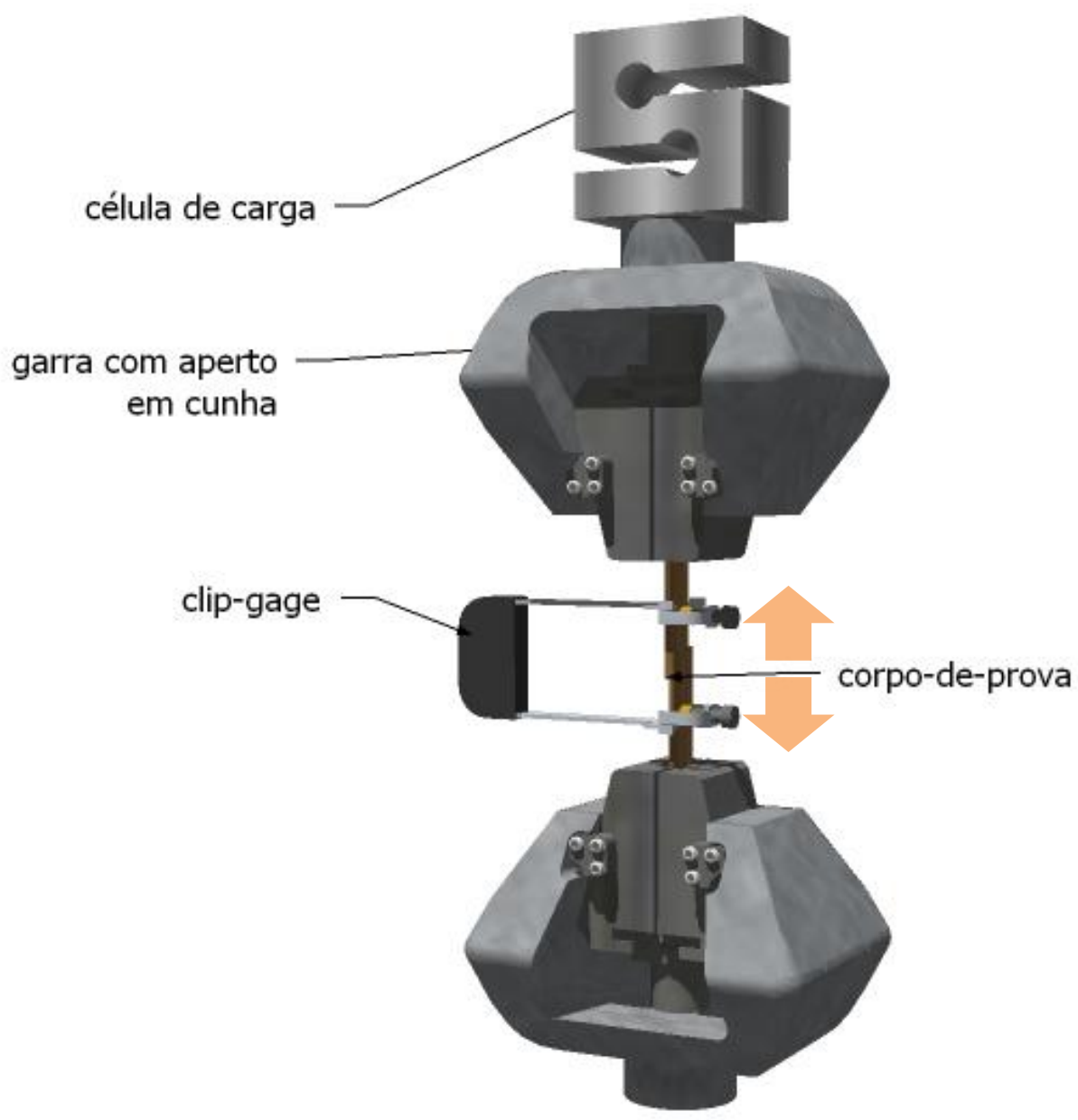

Figura 70: Setup de ensaio de cisalhamento na linha da colagem.

\subsection{Resultados}

\subsubsection{Ensaios de variação de umidade}

A Tabela 15 sumariza as propriedades físicas das amostras para cada condição de umidade a que foram submetidas.

As amostras são nomeadas de acordo com a porção do colmo de onde provêm: $\mathrm{B}$ - base; $\mathrm{M}$ - meio; $\mathrm{T}$ - topo, e segundo a camada da parede de onde foram retiradas: $\mathrm{E}$ - externa; $\mathrm{ME}$ - meso externa; $\mathrm{M}$ - medial; $\mathrm{Ml}$ - meso interna e I - interna, conforme aplicável, considerando que, conforme anteriormente descrito, a porção de base é dividida em 4 camadas (BE, BME, BMI e BI), a de meio em 3 camadas (ME, MM e MI) e a de topo em 2 (TE e TI). 
6.

Tabela 15: Dimensões, volume, massa e densidade das amostras de bambu das diferentes camadas da parede e porções do colmo, sob diferentes condições de umidade.

\begin{tabular}{|c|c|c|c|c|c|c|c|}
\hline \multirow{2}{*}{\multicolumn{2}{|c|}{ amostras }} & \multicolumn{3}{|c|}{ dimensões (mm) } & \multirow{3}{*}{$\begin{array}{c}\begin{array}{c}\text { volume } \\
\text { (cm3) }\end{array} \\
0,512 \\
\end{array}$} & \multirow{3}{*}{\begin{tabular}{|c|} 
massa $(\mathrm{g})$ \\
0,326 \\
\end{tabular}} & \multirow{3}{*}{$\begin{array}{c}\begin{array}{c}\text { densidade } \\
\left(\mathrm{g} / \mathrm{cm}^{3}\right)\end{array} \\
0,636\end{array}$} \\
\hline & & largura & altura & espessura & & & \\
\hline BI & \multirow{9}{*}{ 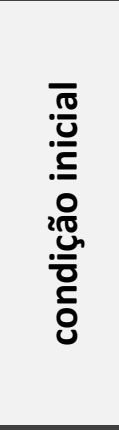 } & 16,00 & 15,25 & 2,10 & & & \\
\hline BMI & & 16,25 & 15,05 & 2,15 & 0,526 & 0,344 & 0,654 \\
\hline BME & & 15,95 & 15,25 & 2,10 & 0,511 & 0,377 & 0,737 \\
\hline BE & & 16,10 & 15,20 & 2,15 & 0,526 & 0,419 & 0,795 \\
\hline MI & & 15,75 & 15,55 & 1,95 & 0,478 & 0,379 & 0,793 \\
\hline $\mathrm{MM}$ & & 16,25 & 15,70 & 1,90 & 0,485 & 0,408 & 0,842 \\
\hline ME & & 15,75 & 15,65 & 1,90 & 0,468 & 0,454 & 0,970 \\
\hline $\mathrm{TI}$ & & 15,55 & 15,65 & 1,95 & 0,475 & 0,356 & 0,750 \\
\hline TE & & 15,50 & 15,45 & 2,00 & 0,479 & 0,458 & 0,956 \\
\hline BI & \multirow{9}{*}{ 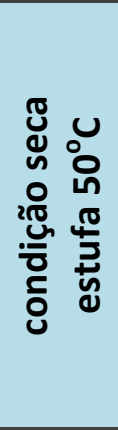 } & 16,00 & 15,25 & 2,10 & 0,512 & 0,306 & 0,598 \\
\hline BMI & & 16,25 & 15,05 & 2,15 & 0,526 & 0,324 & 0,617 \\
\hline BME & & 15,95 & 15,25 & 2,10 & 0,511 & 0,355 & 0,695 \\
\hline BE & & 16,10 & 15,20 & 2,15 & 0,526 & 0,396 & 0,753 \\
\hline MI & & 15,75 & 15,55 & 1,95 & 0,478 & 0,358 & 0,750 \\
\hline MM & & 16,25 & 15,70 & 1,90 & 0,485 & 0,387 & 0,798 \\
\hline ME & & 15,75 & 15,65 & 1,90 & 0,468 & 0,433 & 0,925 \\
\hline $\mathrm{TI}$ & & 15,55 & 15,65 & 1,95 & 0,475 & 0,336 & 0,707 \\
\hline $\mathrm{TE}$ & & 15,50 & 15,45 & 2,00 & 0,479 & 0,434 & 0,907 \\
\hline BI & \multirow{9}{*}{ 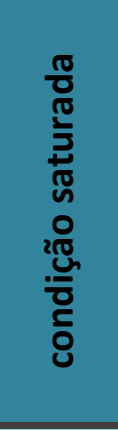 } & 16,65 & 15,50 & 2,85 & 0,736 & 0,743 & 1,010 \\
\hline BMI & & 17,15 & 15,25 & 2,65 & 0,693 & 0,700 & 1,010 \\
\hline BME & & 16,75 & 15,25 & 2,55 & 0,651 & 0,670 & 1,029 \\
\hline BE & & 17,20 & 15,35 & 2,45 & 0,647 & 0,686 & 1,060 \\
\hline MI & & 16,35 & 15,60 & 2,25 & 0,574 & 0,622 & 1,085 \\
\hline MM & & 16,85 & 15,75 & 2,10 & 0,557 & 0,629 & 1,128 \\
\hline ME & & 16,40 & 15,70 & 2,10 & 0,541 & 0,624 & 1,154 \\
\hline $\mathrm{TI}$ & & 15,85 & 15,70 & 2,00 & 0,498 & 0,543 & 1,092 \\
\hline TE & & 15,80 & 15,45 & 2,10 & 0,513 & 0,611 & 1,192 \\
\hline BI & \multirow{9}{*}{ 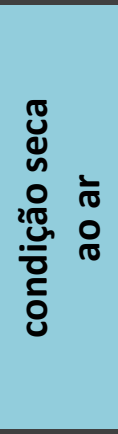 } & 16,15 & 15,40 & 2,50 & 0,622 & 0,312 & 0,502 \\
\hline BMI & & 16,35 & 15,20 & 2,40 & 0,596 & 0,334 & 0,560 \\
\hline BME & & 16,05 & 15,25 & 2,35 & 0,575 & 0,369 & 0,642 \\
\hline BE & & 16,40 & 15,25 & 2,35 & 0,588 & 0,414 & 0,704 \\
\hline MI & & 15,80 & 15,55 & 2,10 & 0,516 & 0,371 & 0,718 \\
\hline MM & & 16,30 & 15,75 & 2,00 & 0,513 & 0,400 & 0,779 \\
\hline ME & & 15,80 & 15,70 & 2,00 & 0,496 & 0,448 & 0,903 \\
\hline TI & & 15,45 & 15,70 & 1,95 & 0,473 & 0,346 & 0,730 \\
\hline $\mathrm{TE}$ & & 15,40 & 15,45 & 2,05 & 0,488 & 0,448 & 0,918 \\
\hline BI & \multirow{9}{*}{ 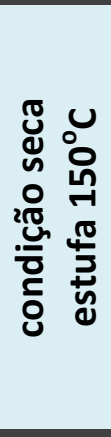 } & 15,75 & 15,35 & 2,45 & 0,592 & 0,280 & 0,472 \\
\hline BMI & & 16,00 & 15,15 & 2,35 & 0,570 & 0,300 & 0,526 \\
\hline BME & & 15,65 & 15,25 & 2,35 & 0,561 & 0,331 & 0,589 \\
\hline BE & & 15,85 & 15,25 & 2,20 & 0,532 & 0,372 & 0,699 \\
\hline MI & & 15,41 & 15,50 & 2,00 & 0,478 & 0,333 & 0,698 \\
\hline MM & & 15,75 & 15,75 & 1,90 & 0,471 & 0,361 & 0,765 \\
\hline ME & & 15,25 & 15,70 & 1,90 & 0,455 & 0,404 & 0,888 \\
\hline $\mathrm{TI}$ & & 15,00 & 15,70 & 1,90 & 0,447 & 0,311 & 0,695 \\
\hline TE & & 14,90 & 15,40 & 1,95 & 0,447 & 0,404 & 0,903 \\
\hline
\end{tabular}


6.

Percebe-se, de acordo com os valores apresentados, que as amostras provenientes das camadas mais internas da parede do colmo tendem a apresentar maior variação nas propriedades, conforme são alteradas as suas condições de umidade, o que pode denotar maior porosidade. De maneira similar, percebe-se que as amostras provenientes da porção basal são as menos estáveis, sob as condições ensaiadas. Tais variações podem ser percebidas com mais clareza na Figura 71, que apresenta um gráfico correlacionando a variação de densidade ao tempo de exposição das amostras às diferentes condições de umidade.

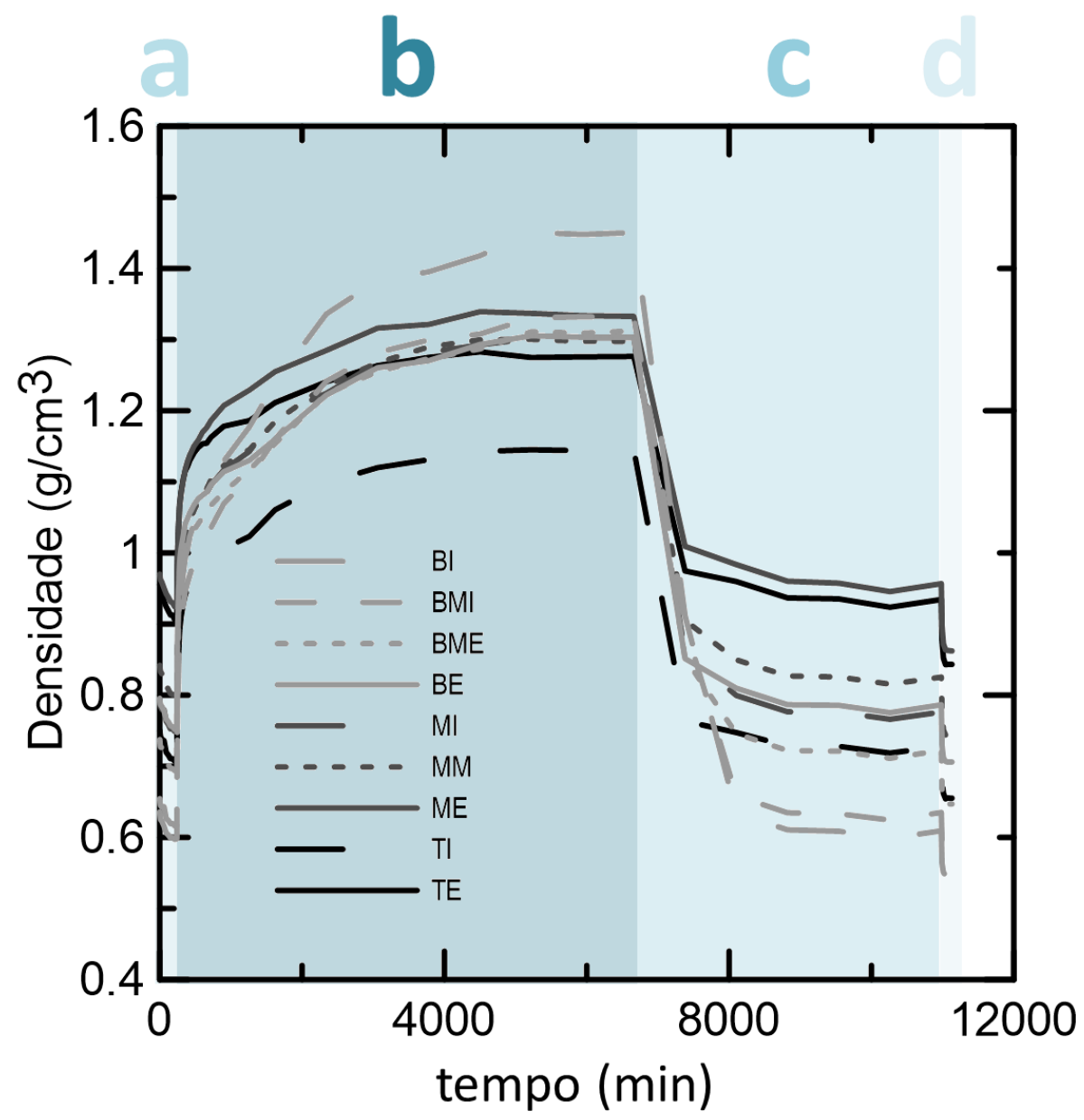

Figura 71: Ensaio de variação de densidade em diferentes processos de secagem e saturação ao longo do tempo: a) secagem a 50ㄷ em estufa; b) saturação em água; c) secagem ao ar e d) secagem em estufa a $150^{\circ} \mathrm{C}$.

A Figura 72 discretiza o gráfico densidade $x$ tempo de exposição, de acordo com as diferentes condições de umidade a que as amostras foram submetidas, permitindo uma análise mais pormenorizada das velocidades de 
6.

absorção e perda de água, bem como das curvas de estabilização de cada amostra.
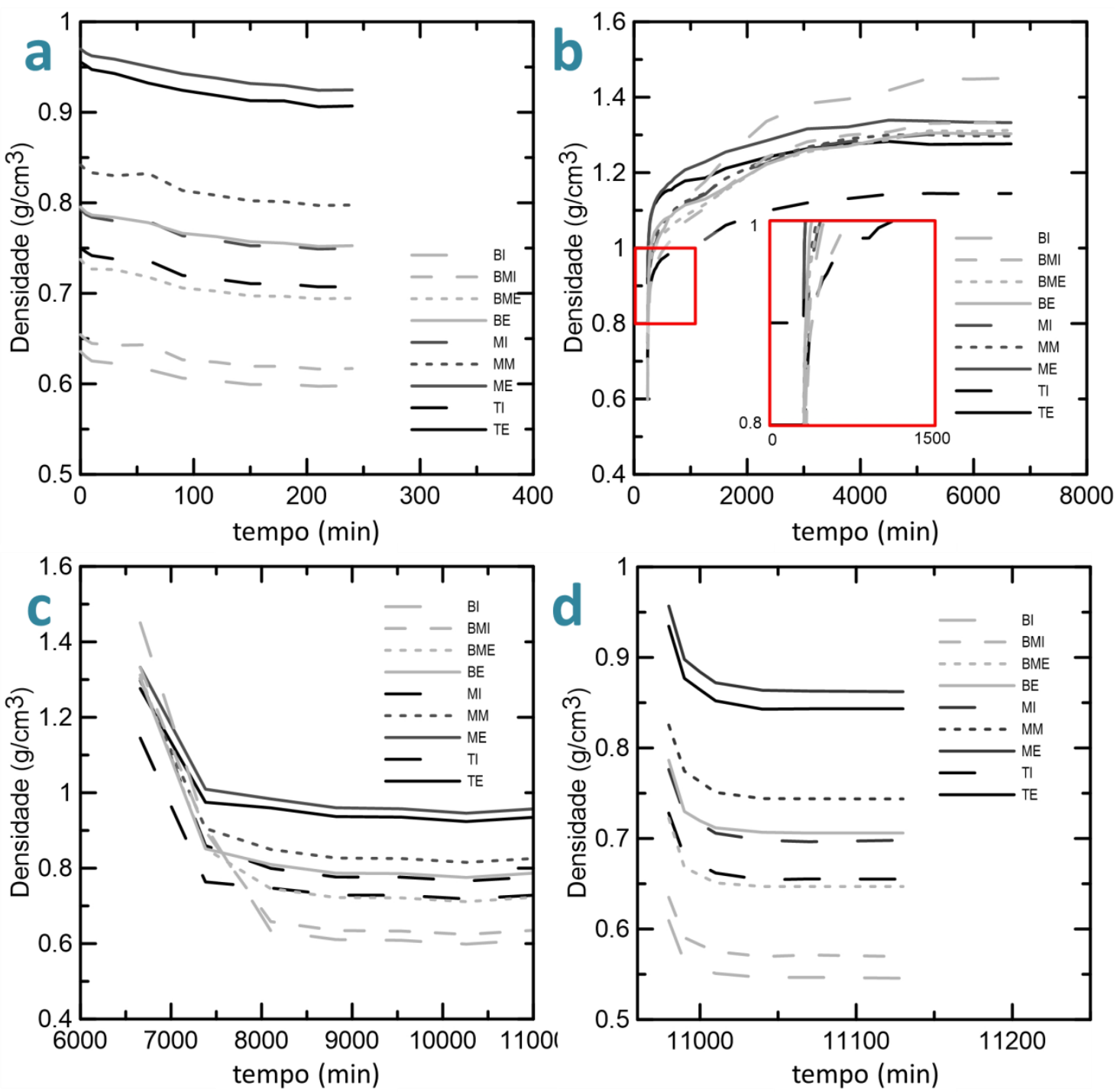

Figura 72: Detalhamento dos processos presentes na Figura 71: a) secagem a 50ㄷ em estufa; b) saturação em água; c) secagem ao ar e d) secagem em estufa a 150ㄷ․

O primeiro processo de alteração de umidade, secagem em estufa a $50^{\circ} \mathrm{C}$, tencionava homogeneizar as condições basais de umidade. Pelo gráfico da Figura $72 a$, percebe-se que a condição inicial já era homogênea, uma vez que todas as amostras apresentaram uma perda discreta e quase linear de água, com coeficiente angular bastante similar. A curva de saturação, apresentada na Figura $72 b$, permite observar que a absorção se dá em um prazo similar para todas as amostras, dado o trecho linear praticamente vertical, comum a todas as amostras. As curvas de estabilização, entretanto apresentam diferenças 
6.

perceptíveis. As curvas que apresentam estabilização mais brusca, notadamente ME e TE, denotam menor porosidade do parênquima e, consequentemente, maior presença de fibras, menor fração volumétrica de matriz e maior velocidade de absorção. A maior presença de fibras pressupõe maior presença de vasos condutores, uma vez que aquelas envolvem e protegem estes, sendo esses mesovazios preenchidos mais rapidamente. A estabilização mais repentina ocorre por haver menor migração de água para os microvazios e entre eles, o que ocorreria mais gradualmente. Tal redução de velocidade se deve à restrição de vazão provocada pela passagem da água pelos canalículos de conexão entre as células parenquimatosas, bem como ao fato de o desalinhamento entre estas células e a dispersão dos poros de comunicação não contam com o efeito de capilaridade inerente aos vasos condutores principais. Nesse ínterim, percebe-se que a amostra $\mathrm{Bl}$ é a mais instável quanto à variação de densidade e possui a saturação mais suave, denotando maior presença de vazios no parênquima. A amostra TI apresenta um comportamento similar ao das amostras menos porosas, porém com densidade sempre inferior a destas, denotando menor presença de continentes sólidos, com constituição similar. A menor variação de densidade em relação às demais amostras de camada interna aliada ao comportamento similar ao das amostras menos porosas pode pressupor maior preenchimento dos poros do parênquima com substâncias inorgânicas, o que evitaria o seu preenchimento com água. Estas substâncias não foram quantificadas neste trabalho. As demais amostras apresentam comportamento similar entre si, intermediário aos extremos aqui destacados. O processo de secagem ao ar (Figura 72c) reitera as observações feitas no processo de saturação, detacando como mais porosas as amostras que apresentam maior amplitude entre as condições saturada e seca e com mais vazios no parênquima as que tem estabilização mais suave. De modo similar ao primeiro processo de secagem em estufa, a curva mostrada na Figura $72 d$ apresenta comportamento paralelo entre as amostras, o que denota que diferentes escalas de secagem não alteram o comportamento das amostras, somente os seus quantitativos.

A Tabela 16 apresenta as propriedades físicas medidas e as calculadas de acordo com as equações apresentadas no capítulo 6.2, para amostras provenientes das diferentes camadas e porções do colmo de Dendrocalamus giganteus. 
6.

Tabela 16: Quadro com as propriedades físicas medidas e calculadas para amostras das diferentes camadas da parede e porções do colmo de Dendrocalamus giganteus.

\begin{tabular}{|c|c|c|c|c|c|c|c|c|}
\hline amostras & $A(\%)$ & $\begin{array}{c}V \\
\left(\mathrm{~g} / \mathrm{cm}^{3}\right)\end{array}$ & $\begin{array}{c}\text { Massa } \\
\text { água } C_{\text {sat }} \\
\text { (g) }\end{array}$ & $\begin{array}{l}\mathbf{v}_{\mathrm{eq}} \\
\text { água } \\
\left(\mathrm{cm}^{3}\right)\end{array}$ & $\begin{array}{l}\text { Fração vol. } \\
\text { vazios } \\
\text { estimada } \\
\text { C }_{\text {sat }}(\%)\end{array}$ & $\begin{array}{l}\text { Volume } \\
\text { de } \\
\text { sólidos } \\
\left(\mathrm{cm}^{3}\right)\end{array}$ & $\begin{array}{c}\begin{array}{c}\text { Volume } \\
\text { de }\end{array} \\
\text { vazios } \\
\mathrm{C}_{\mathrm{i}}\left(\mathrm{cm}^{3}\right)\end{array}$ & $\begin{array}{l}\text { Fração vol. } \\
\text { vazios } \\
\text { estimada } \\
C_{i}(\%)\end{array}$ \\
\hline BI & 165,808 & 0,546 & 0,464 & 0,464 & 63,031 & 0,272 & 0,240 & 46,933 \\
\hline BMI & 133,823 & 0,570 & 0,401 & 0,401 & 57,829 & 0,292 & 0,234 & 44,414 \\
\hline BME & 102,814 & 0,647 & 0,340 & 0,340 & 52,167 & 0,312 & 0,199 & 39,004 \\
\hline $\mathrm{BE}$ & 84,576 & 0,706 & 0,314 & 0,314 & 48,574 & 0,333 & 0,193 & 36,777 \\
\hline MI & 86,683 & 0,698 & 0,289 & 0,289 & 50,359 & 0,285 & 0,193 & 40,348 \\
\hline MM & 74,452 & 0,744 & 0,268 & 0,268 & 48,160 & 0,289 & 0,196 & 40,398 \\
\hline ME & 54,557 & 0,862 & 0,220 & 0,220 & 40,743 & 0,320 & 0,148 & 31,584 \\
\hline TI & 74,751 & 0,655 & 0,232 & 0,232 & 46,696 & 0,265 & 0,209 & 44,096 \\
\hline TE & 51,349 & 0,843 & 0,207 & 0,207 & 40,458 & 0,305 & 0,174 & 36,271 \\
\hline
\end{tabular}

Analisando os dados pode-se perceber que a porcentagem de absorção de água em massa, relativa ao peso seco é sempre muito alta, variando de cerca de $50 \%$ até mais de $150 \%$ do peso das amostras. Aliando-se a isso o fato de os principais constituintes do bambu, celulose e lignina, têm densidades aproximadas de respectivamente 1,5 e $1,2 \mathrm{~g} / \mathrm{cm}^{3}$ e que a densidade seca das amostras, embora bastante variável seja sempre inferior a $1 \mathrm{~g} / \mathrm{cm}^{3}$, espera-se naturalmente um índice elevado de vazios. As Frações volumétricas de vazios obtidas pelo método proposto são, em geral, ligeiramente maiores que as observadas e quantificadas por processamento digital de imagens (PDI) no capítulo 4.6, mas apresentam coerência de proporcionalidade. As diferenças podem ter várias explicações, de acordo com a amostra analisada, mas de um modo geral parece lógico que o teor seja superior, dado que nem todos os vazios foram quantificados por PDI. Os vazios relativos ao esclerênquima, por exemplo lumens e fissuras, foram desconsiderados Para as amostras da porção basal não é possível tecer comentários, uma vez que não foi possível quantificar os teores de vazios por PDI. A Figura 73 apresenta graficos com as frações volumétricas estimadas a partir do método proposto e as obtidas por PDI, comparando-os quando possível. 
6.
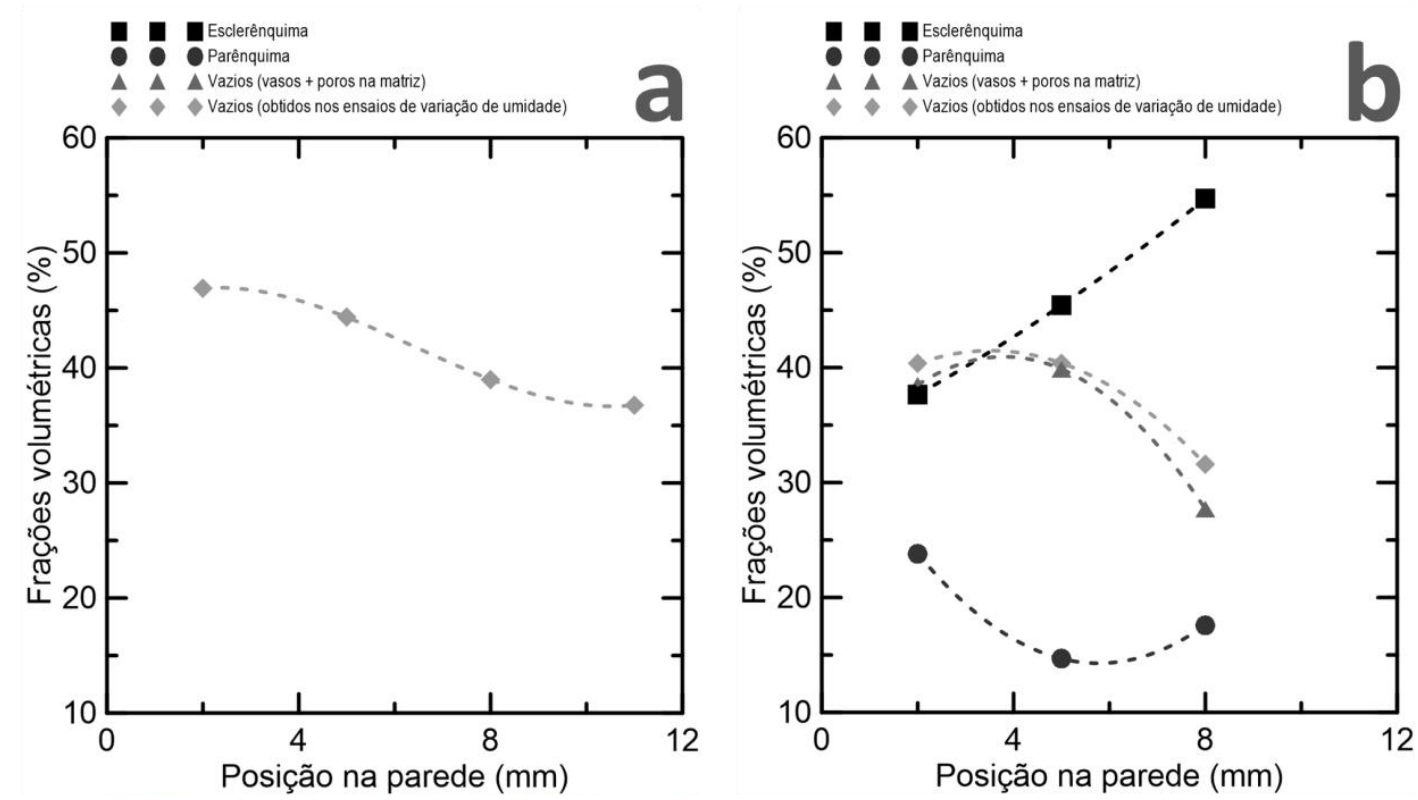

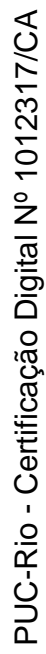
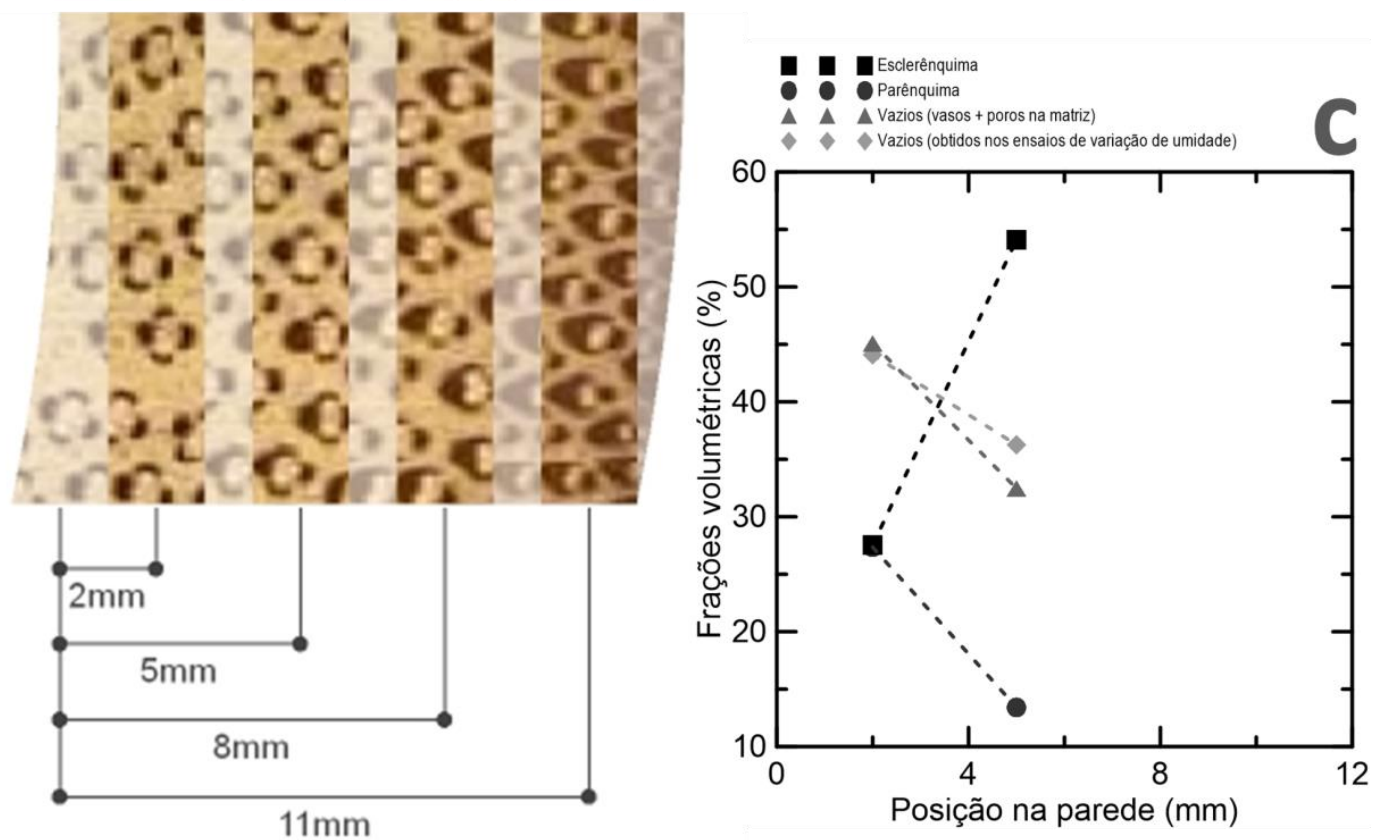

Figura 73: Gráficos de variação de frações volumétricas de fibras, matriz e vazios (estes obtidos por processamento digital de imagens e a partir da formulação proposta baseada nos resultados dos ensaios de variação de umidade) de: a) Porção basal do colmo (somente fração volumétrica de vazios pelo método proposto). Inclui referência de numeração da abcissa, que vale para os demais; b) Porção medial e c) Porção apical.

Observa-se que os valores obtidos são bastante próximos. A única amostra que apresentou fração volumétrica de vazios inferior pelo método proposto em relação a PDI, foi a proveniente da parte interna de uma porção apical do colmo. Esta amostra, especificamente, possui elevada concentração de material inorgânico, que pode ser observada na Figura 24. 
6.

A Tabela 17 apresenta os resultados dos ensaios de estabilidade dimensional das amostras, em relação ao volume e a cada uma de suas dimensões principais (transversal, longitudinal e radial).

Tabela 17: Resultados dos ensaios de estabilidade dimensional em relação ao volume de cada amostra e às suas dimensões.

\begin{tabular}{|l|r|r|r|r|}
\hline \multicolumn{1}{|c|}{ amostras } & $\mathbf{V}_{\text {tangencial }}(\mathbf{\%})$ & $\mathbf{V}_{\text {longitudinal }}(\mathbf{\%})$ & $\mathbf{V}_{\text {radial }}$ (\%) & $\mathbf{V}_{\text {volumétrica }}$ (\%) \\
\hline BI & 4,062 & 1,639 & 35,714 & 43,543 \\
\hline BMI & 5,538 & 1,329 & 23,256 & 31,811 \\
\hline BME & 5,016 & 0,000 & 21,429 & 27,519 \\
\hline BE & 6,832 & 0,987 & 13,953 & 22,941 \\
\hline MI & 3,810 & 0,322 & 15,385 & 20,165 \\
\hline MM & 3,692 & 0,318 & 10,526 & 14,972 \\
\hline ME & 4,127 & 0,319 & 10,526 & 15,455 \\
\hline TI & 1,929 & 0,319 & 2,564 & 4,877 \\
\hline TE & 1,935 & 0,000 & 5,000 & 7,032 \\
\hline
\end{tabular}

Verifica-se que a direção que sofre maior variação é a correspondente ao eixo radial e a que sofre as menores variações é a correspondente ao eixo longitudinal. Tal resultado é esperado, considerando que o sentido de reforço é longitudinal e que a menor dimensão, não reforçada é a do eixo radial, o que diminui a influência da morfologia do material que, de um modo ou outro poderia limitar tal variação, conforme ocorre no eixo tangencial.

\subsubsection{Ensaios de tração longitudinal às fibras}

A Tabela 18 apresenta a lista dos corpos-de-prova, suas características pré-ensaio, seus modos de ruptura e algumas das propriedades mecânicas obtidas e a Figura 74 as curvas tensão x deformação de todos os ensaios, divididas por blocos de corpos-de-prova. Cada bloco, por porção do colmo, provém de uma unica régua dividida nas camadas que a compõem. Com relação às características pré-ensaio, todas as amostras apresentavam umidade superficial aceitável para trabalhabilidade em madeiras $(<13 \%)$ e, densidades coerentes com a sua posição. 
6.

Tabela 18: Lista de corpos-de-prova das regiões basal, medial e apical, provenientes das diferentes camadas da parede do colmo, com informações gerais imediatamente anteriores ao ensaio, descrição sumarizada dos modos de ruptura e registros de tensão máxima, deformação global máxima equivalente e modulo de elasticidade obtidos nos ensaios à tração.

\begin{tabular}{|c|c|c|c|c|c|c|c|c|}
\hline corpos-de-prova & $\begin{array}{c}\text { umidade } \\
\text { superficial } \\
(\%)\end{array}$ & $\begin{array}{c}\text { volume } \\
\text { (cm3) }\end{array}$ & $\begin{array}{c}\text { massa } \\
\text { (g) }\end{array}$ & $\begin{array}{c}\text { densidade } \\
\text { (g/cm3) }\end{array}$ & modo de falha & $\begin{array}{c}\sigma_{\text {máx }} \\
\text { (MPa) }\end{array}$ & $\varepsilon_{\text {máx }}$ & $\begin{array}{c}E \\
(\mathrm{GPa})\end{array}$ \\
\hline BE1 & 5 & 10,30 & 9,86 & 0,96 & tração - fibras & 300,86 & 0,01 & 37,80 \\
\hline BME1 & 5 & 10,51 & 8,23 & 0,78 & tração - fibras & 196,73 & 0,01 & 28,24 \\
\hline BMI1 & 7 & 10,97 & 8,00 & 0,73 & tração - fibras & 184,75 & 0,01 & 21,74 \\
\hline BI1 & 8 & 11,26 & 7,07 & 0,63 & tração - fibras & 147,92 & 0,01 & 18,61 \\
\hline BE2 & 4 & 10,04 & 9,53 & 0,95 & tração - fibras & 283,86 & 0,02 & 30,55 \\
\hline BME2 & 5 & 10,63 & 8,60 & 0,81 & tração - fibras & 219,14 & 0,02 & 27,72 \\
\hline BMI2 & 7 & 10,35 & 7,75 & 0,75 & tração - fibras & 200,20 & 0,01 & 20,00 \\
\hline B12 & 8 & 11,18 & 7,39 & 0,66 & tração - fibras & 185,25 & 0,01 & 16,26 \\
\hline BE3 & 4 & 10,38 & 10,95 & 1,06 & tração - fibras & 297,37 & 0,01 & 33,35 \\
\hline BME3 & 3 & 10,35 & 8,10 & 0,78 & tração - fibras & 214,09 & 0,01 & 23,15 \\
\hline BMI3 & 6 & 11,21 & 7,71 & 0,69 & tração - fibras & 177,32 & 0,01 & 19,16 \\
\hline $\mathrm{B} \mid 3$ & 8 & 10,58 & 7,32 & 0,69 & tração - fibras & 182,72 & 0,03 & 16,88 \\
\hline BE4 & 2 & 10,05 & 10,27 & 1,02 & tração - fibras & 312,49 & 0,04 & 28,76 \\
\hline BME4 & 3 & 11,02 & 9,17 & 0,83 & tração - fibras & 227,29 & 0,01 & 24,33 \\
\hline BMI4 & 8 & 11,70 & 8,43 & 0,72 & tração - fibras & 196,44 & 0,01 & 20,39 \\
\hline BI4 & 11 & 11,81 & 7,82 & 0,66 & tração - fibras & 199,31 & 0,01 & 21,38 \\
\hline BE5 & 3 & 10,04 & 9,88 & 0,98 & tração - fibras & 273,39 & 0,05 & 32,40 \\
\hline BME5 & 6 & 10,95 & 8,61 & 0,79 & tração - fibras & 218,09 & 0,05 & 25,95 \\
\hline BMI5 & 11 & 10,89 & 7,87 & 0,72 & tração - fibras & 205,02 & 0,01 & 19,68 \\
\hline B15 & 6 & 10,37 & 6,95 & 0,67 & tração - fibras & 176,24 & 0,01 & 18,19 \\
\hline ME1 & 1 & 9,74 & 9,76 & 1,00 & tração - fibras & 348,33 & 0,01 & 32,86 \\
\hline MM1 & 4 & 10,16 & 8,04 & 0,79 & tração - fibras & 228,99 & 0,01 & 22,06 \\
\hline MI1 & 8 & 10,04 & 6,42 & 0,64 & $\begin{array}{l}\text { tração - bloco } \\
\text { (junto à garra) }\end{array}$ & 172,78 & 0,01 & 14,70 \\
\hline ME2 & 1 & 9,57 & 9,70 & 1,01 & tração - fibras & 372,38 & 0,05 & 36,86 \\
\hline MM2 & 4 & 10,40 & 8,72 & 0,84 & tração - fibras & 233,46 & 0,01 & 24,36 \\
\hline MI2 & 2 & 10,21 & 7,21 & 0,71 & tração - fibras & 187,40 & 0,02 & 17,74 \\
\hline ME3 & 1 & 9,86 & 9,48 & 0,96 & tração - fibras & 292,96 & 0,01 & 32,85 \\
\hline MM3 & 3 & 10,19 & 9,08 & 0,89 & tração - fibras & 233,48 & 0,01 & 28,67 \\
\hline MI3 & 10 & 10,21 & 6,94 & 0,68 & tração - fibras & 181,63 & 0,01 & 20,84 \\
\hline ME4 & 1 & 10,12 & 9,66 & 0,95 & $\begin{array}{l}\text { tração - fibras + } \\
\text { cisalhamento } \\
\text { modo } 2 \text { (cis) }\end{array}$ & 337,52 & 0,01 & 28,04 \\
\hline MM4 & 3 & 10,14 & 8,44 & 0,83 & tração - fibras & 259,87 & 0,01 & 22,58 \\
\hline MI4 & 3 & 10,02 & 7,23 & 0,72 & tração - fibras & 223,45 & 0,01 & 18,85 \\
\hline ME5 & 1 & 9,99 & 9,65 & 0,97 & tração - fibras & 280,19 & 0,03 & 23,11 \\
\hline MM5 & 4 & 9,62 & 7,59 & 0,79 & tração - fibras & 278,81 & 0,03 & 38,71 \\
\hline MI5 & 8 & 10,12 & 7,12 & 0,70 & tração - fibras & 203,16 & 0,02 & 15,90 \\
\hline TE1 & 1 & 10,97 & 11,16 & 1,02 & tração - fibras + cis & 231,57 & 0,01 & 24,57 \\
\hline TI1 & 1 & 10,95 & 9,27 & 0,85 & tração - fibras + cis & 166,15 & 0,01 & 18,59 \\
\hline TE2 & 1 & 10,43 & 10,39 & 1,00 & tração - fibras + cis & 251,15 & 0,05 & 18,65 \\
\hline $\mathrm{TI2}$ & 1 & 10,33 & 8,95 & 0,87 & tração - fibras & 182,65 & 0,06 & 9,81 \\
\hline TE3 & 1 & 10,50 & 9,51 & 0,91 & tração - fibras + cis & 226,05 & 0,01 & 17,15 \\
\hline TI3 & 2 & 10,35 & 7,81 & 0,75 & tração - fibras & 176,88 & 0,01 & 12,20 \\
\hline TE4 & 1 & 10,38 & 10,93 & 1,05 & tração - fibras & 230,31 & 0,01 & 21,13 \\
\hline TI4 & 1 & 10,43 & 9,26 & 0,89 & tração - fibras + cis & 182,35 & 0,01 & 21,11 \\
\hline TE5 & 1 & 10,89 & 10,16 & 0,93 & tração - fibras & 259,98 & 0,01 & 23,37 \\
\hline TI5 & 2 & 10,50 & 8,36 & 0,80 & tração - fibras & 190,97 & 0,09 & 17,60 \\
\hline
\end{tabular}


6.

\section{corpo-de-prova 1}

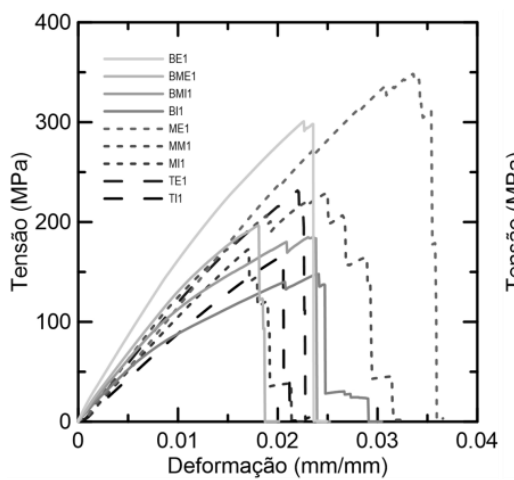

corpo-de-prova 2

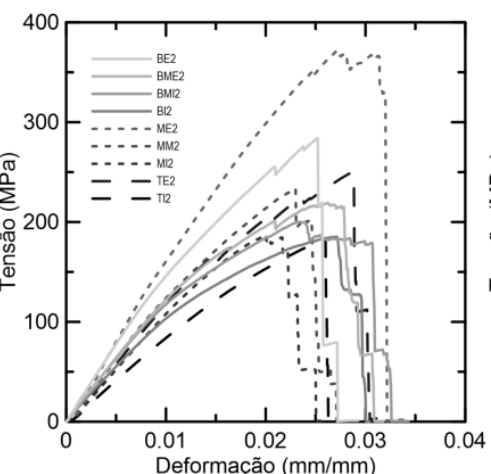

corpo-de-prova 3

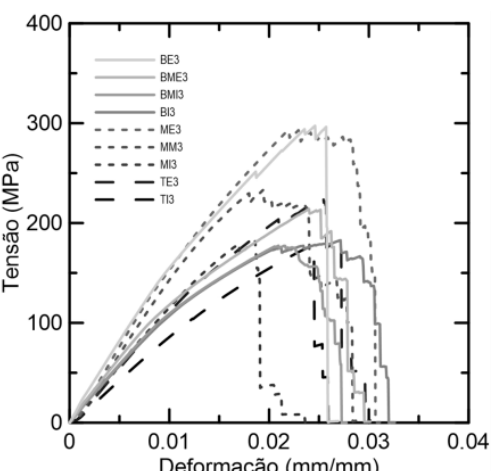

corpo-de-prova 4

corpo-de-prova 5
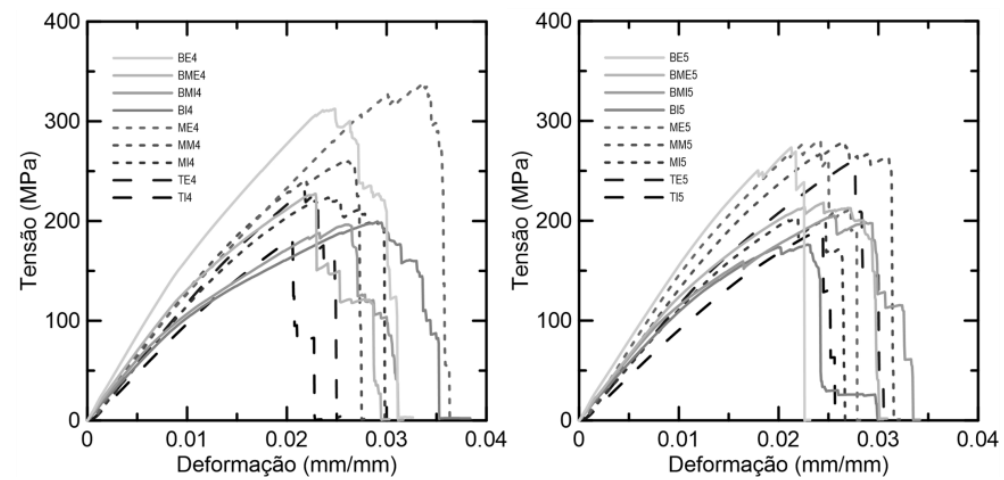

Figura 74: Curvas tensão deformação das diferentes camadas e porções do colmo, separadas por blocos de corpos-de-prova.

Um resumo com as médias e desvios padrão dos resultados e curvas representativas dos ensaios estão consolidados abaixo na Tabela 19 e na Figura 75.

Tabela 19: Médias e desvios padrão das densidades, tensões máximas, deformações máximas equivalentes (computadas quando da tensão máxima) e módulos de elasticidade, obtidas pelos corpos-de-prova ensaiados à tração, bem como suas propriedades específicas.

\begin{tabular}{|l|r|r|r|r|r|r|r|r|r|r|}
\hline corpos-de-prova & $\boldsymbol{V}_{\text {med }}$ & $\boldsymbol{V}_{\text {std }}$ & $\boldsymbol{\sigma}_{\text {med }}$ & $\boldsymbol{\sigma}_{\text {std }}$ & $\boldsymbol{\varepsilon}_{\text {med }}$ & $\boldsymbol{\varepsilon}_{\text {std }}$ & $\mathbf{E}_{\text {med }}$ & $\mathbf{E}_{\text {std }}$ & $\boldsymbol{\sigma} / \mathbf{V}$ & $\mathbf{E} / \mathbf{V}$ \\
\hline BE & 0,99 & 0,04 & 293,60 & 13,62 & 0,03 & 0,02 & 32,57 & 3,05 & 296,57 & 32,90 \\
\hline BME & 0,80 & 0,02 & 215,07 & 10,12 & 0,02 & 0,02 & 25,88 & 1,94 & 268,84 & 32,35 \\
\hline BMI & 0,72 & 0,02 & 192,75 & 10,22 & 0,01 & 0,00 & 20,19 & 0,87 & 267,71 & 28,04 \\
\hline BI & 0,66 & 0,02 & 178,29 & 16,95 & 0,02 & 0,01 & 18,26 & 1,78 & 270,14 & 27,67 \\
\hline ME & 0,98 & 0,02 & 326,28 & 34,56 & 0,02 & 0,02 & 30,74 & 4,73 & 332,94 & 31,37 \\
\hline MM & 0,83 & 0,04 & 246,92 & 19,33 & 0,01 & 0,01 & 27,28 & 6,17 & 297,49 & 32,87 \\
\hline MI & 0,69 & 0,03 & 193,68 & 17,87 & 0,01 & 0,00 & 17,61 & 2,16 & 280,70 & 25,52 \\
\hline TE & 0,98 & 0,05 & 239,81 & 13,29 & 0,02 & 0,01 & 20,98 & 2,78 & 244,70 & 21,41 \\
\hline TI & 0,83 & 0,05 & 179,80 & 8,18 & 0,04 & 0,03 & 15,86 & 4,20 & 216,63 & 19,11 \\
\hline
\end{tabular}


6.
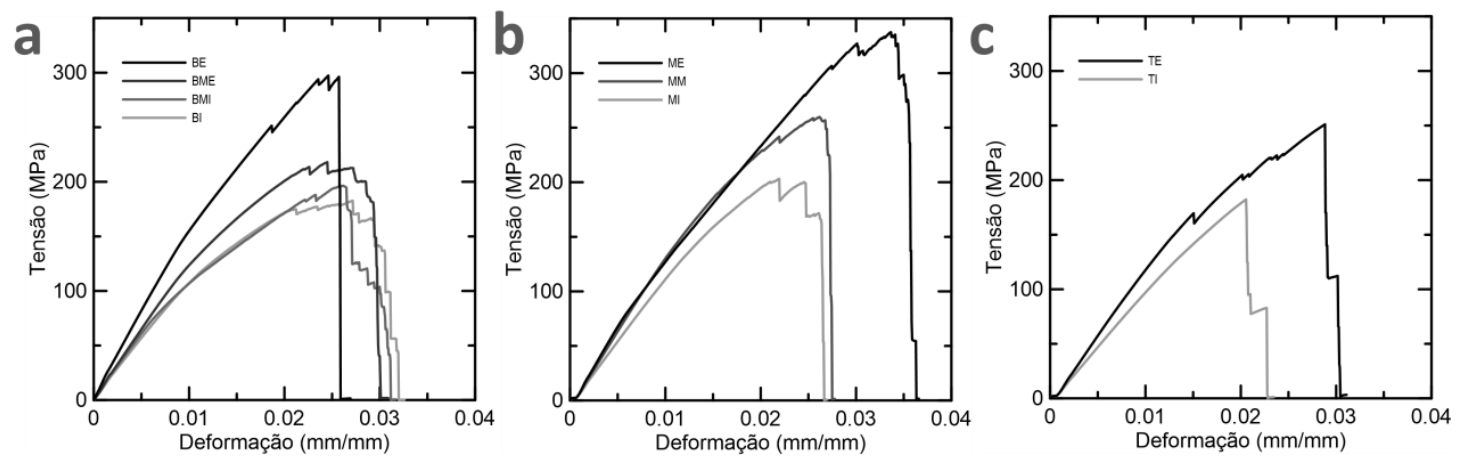

Figura 75: Gráficos tensão x deformação de curvas representativas de corpos-deprova provenientes dos diferentes pontos das paredes das porções de colmo: a) basal; b) medial e c) apical.

Diferentemente dos corpos-de-prova de tração dos ensaios de controle à tração baseado na norma ASTM D 3039 [85], o modo de falha característico não é heterogêneo, isto é, não apresenta em um mesmo corpo-de-prova ruptura gradual das fibras em uma parte e em bloco em outra. A explicação é simples: em lâminas extraídas na direção tangencial do colmo a fração volumétrica dos constituintes é consideravelmente mais homogênea, principalmente em espessuras reduzidas, em oposição a laminas retiradas na direção radial. Assim não há, em um mesmo corpo-de-prova, regiões mais resistentes e outras menos, tal que a tensão se concentre ora numa parte ora em outra. Considerando que todos os corpos-de-prova se caracterizam como compósitos polissacarídicos reforçados por fibras longas, embora com frações volumétricas de reforço distintas de acordo com a posição na parede do colmo, todas as rupturas tendem a ocorrer sob a dominância do reforço, com poucas exceções. As propriedades no entanto, variam, conforme a distribuição das frações constituintes de cada lâmina.

Três diferentes grupos de modos de ruptura foram observados, embora haja uma predominância clara de um em detrimento dos demais (Figura 76):

Grupo 1: ruptura gradual das fibras. Trata-se do modo classico de ruptura à tração de compósitos reforçados por fibras longas. O modo de ruptura sob tracionamento é regido especialmente pela resistência do reforço;

Grupo 2: ruptura do grupo 1 associada a cisalhamento longitudinal do corpo de prova; 
6.

Grupo 3: ruptura em bloco. Normalmente ocorre junto à garra e em corposde-prova com menor fração volumétrica de fibras, de modo que a falha é dominada pelo comportamento da matriz.
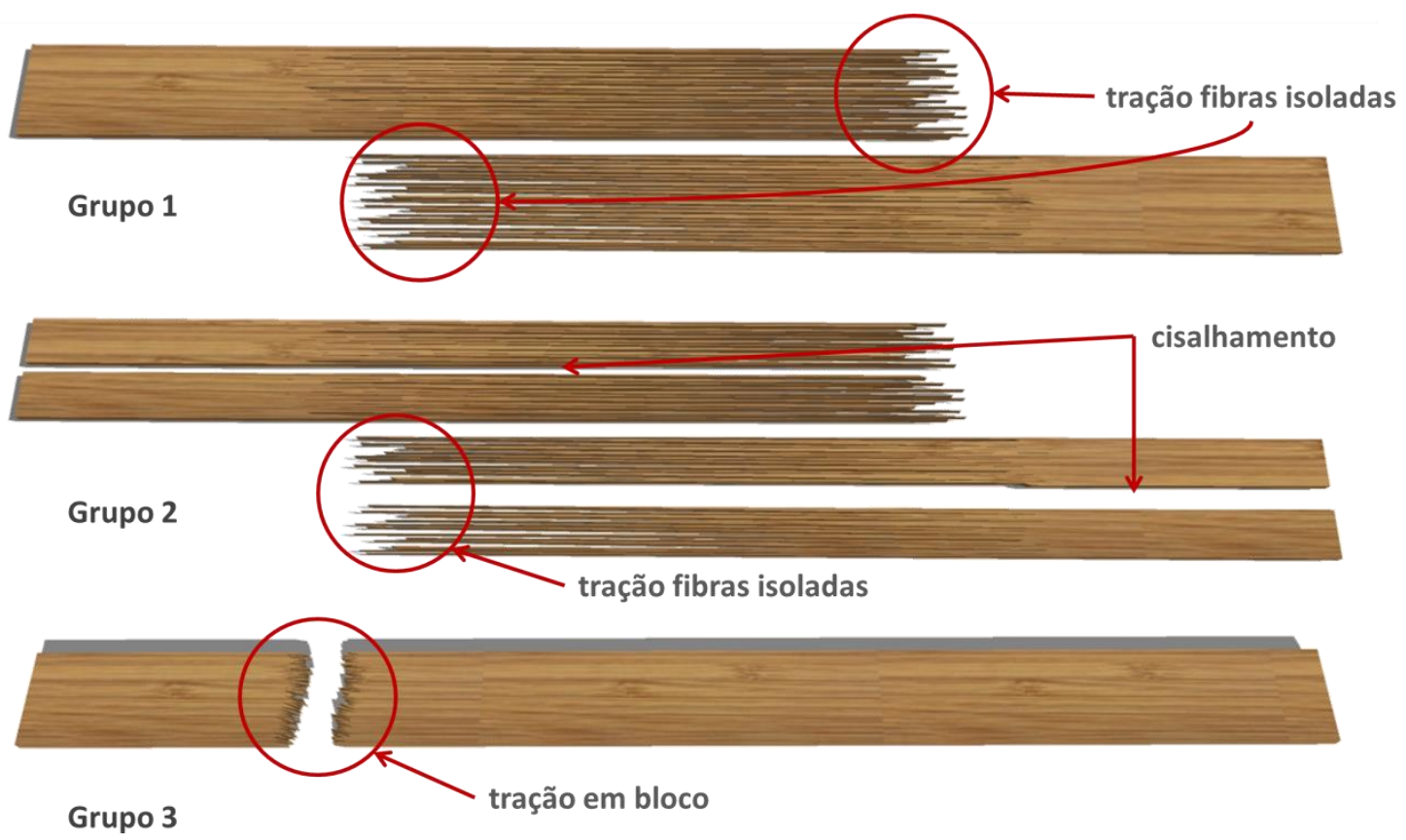

Figura 76: llustração dos modos de ruptura observados nos ensaios à tração de lâminas procedentes de diferentes posições da parede e porções do colmo de bambu da espécie Dendrocalamus giganteus.

As falhas classificadas como pertinentes ao Grupo 1 sao largamente dominantes, caracterizando $100 \%$ dos corpos-de-prova da região basal, $86,7 \%$ dos da região medial e 50\% dos da região apical. 6,7\% (um corpo-de-prova, proveniente da camada mais externa da parede) das falhas na região medial e $50 \%$ das da região apical apresentam ruptura enquadrada como Grupo 2. Mais pormenorizadamente, $30 \%$ destas falhas ocorreram em corpos-de-prova provenientes da camada mais externa e $20 \%$ da mais interna. Apenas um corpode-prova, proveniente da região medial (camada interna), apresentou falha consistente com o Grupo 3. 
6.
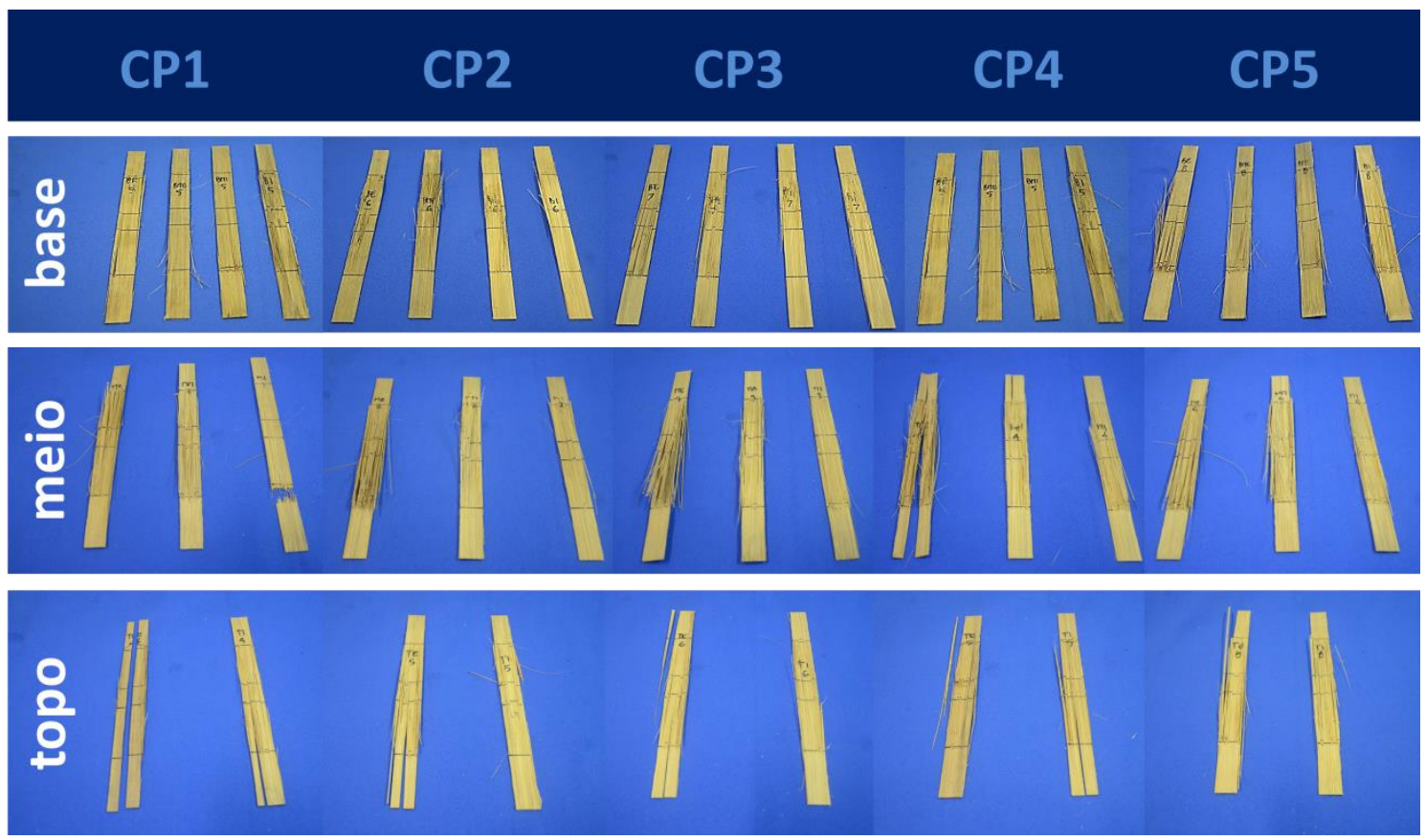

Figura 77: Modos de falha dos corpos-de-prova de tração. Cada porção do colmo está dividida em subconjuntos. Cada bloco numerado (CP) provem de uma mesma régua, dividida em sua espessura. As camadas mais externas estão à esquerda de cada bloco, variando gradualmente até as mais internas à direita.

A maior presença de rupturas Grupo 2 na região apical pode ter influido em sua resistência inferior em relação aos corpos-de-prova da porção medial e pode ter ocorrido por sua menor fração volumétrica de fibras e maiores de matriz e vazios, considerando que as propriedades à tração em compósitos de fibras longas são dominadas pelo reforço, conforme expresso anteriormente.

A Figura 78, a Figura 79 e a Figura 80 comparam respectivamente frações volumétricas de fibras, matriz e vazios com propriedades mecânicas obtidas nos ensaios à tração. 
6.
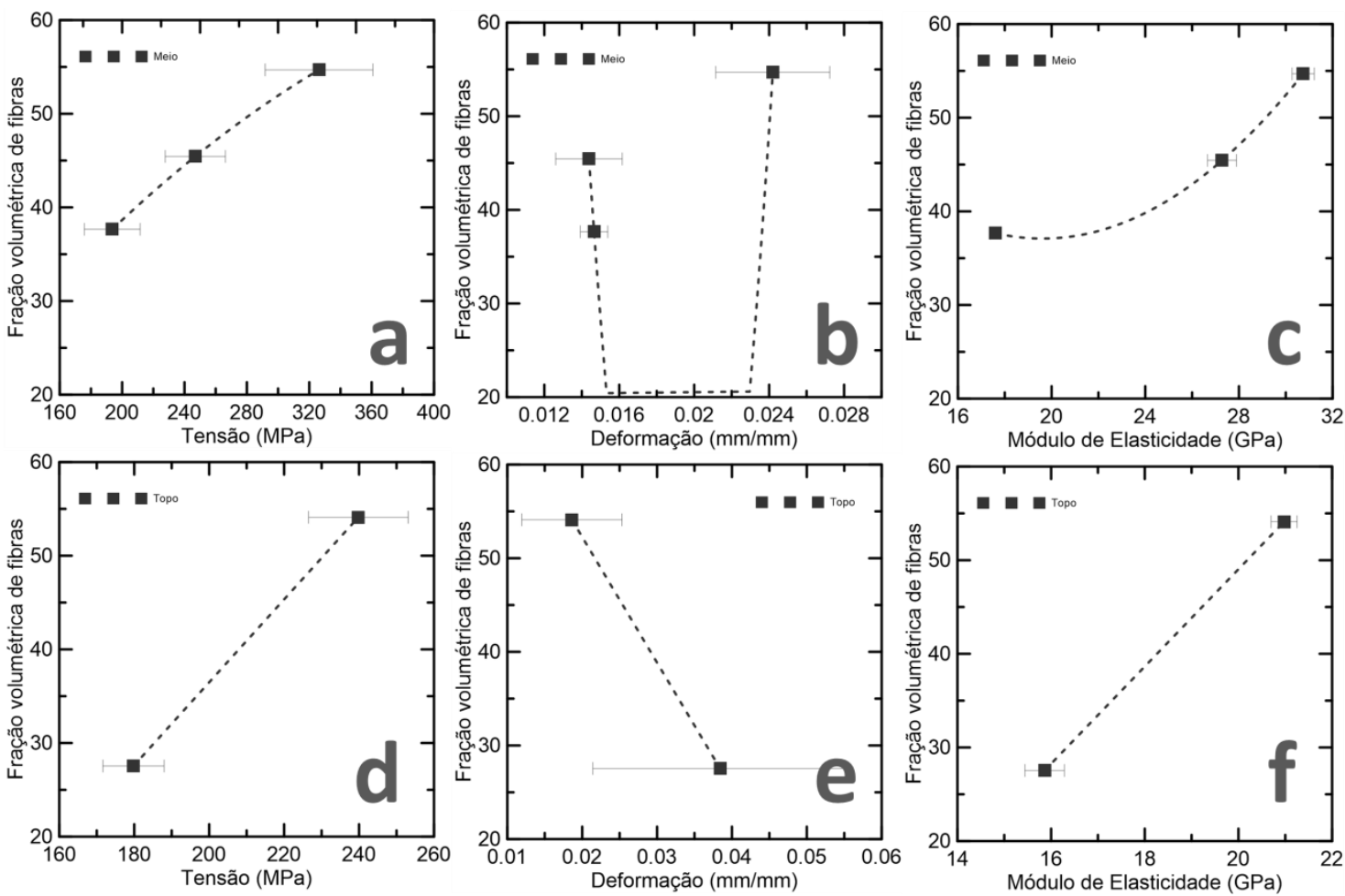

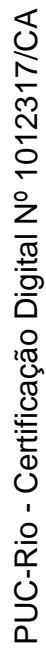

Figura 78: Relação entre a fração volumétrica de fibras e: a) tensão na região medial; b) deformação na região medial; c) módulo de elasticidade na região medial; d) tensão na região apical; e) deformação na região apical e f) módulo de elasticidade na região apical.
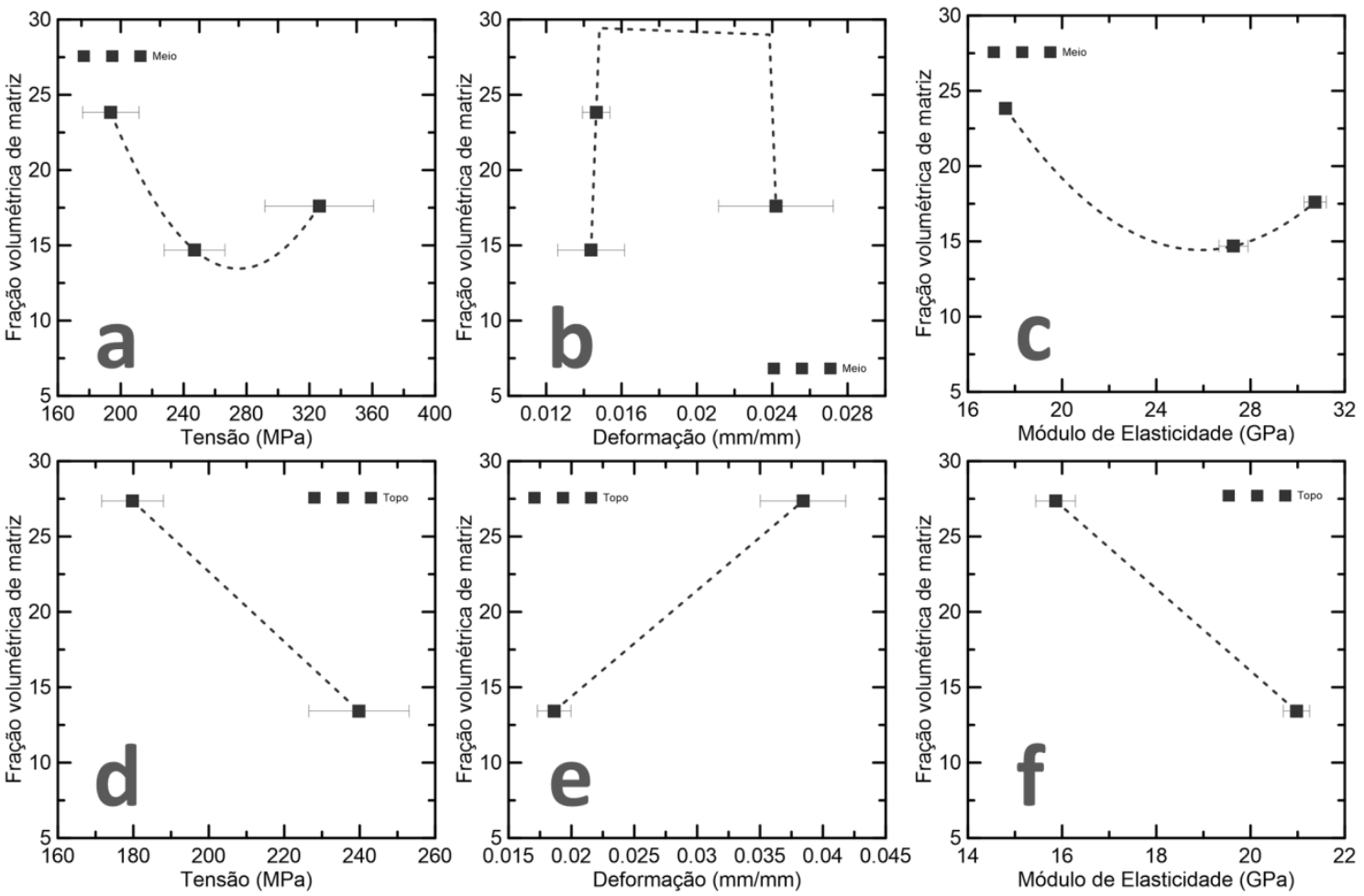

Figura 79: Relação entre a fração volumétrica de matriz e: a) tensão na região medial; b) deformação na região medial; c) módulo de elasticidade na região medial; d) tensão na região apical; e) deformação na região apical e f) módulo de elasticidade na região apical. 
6.
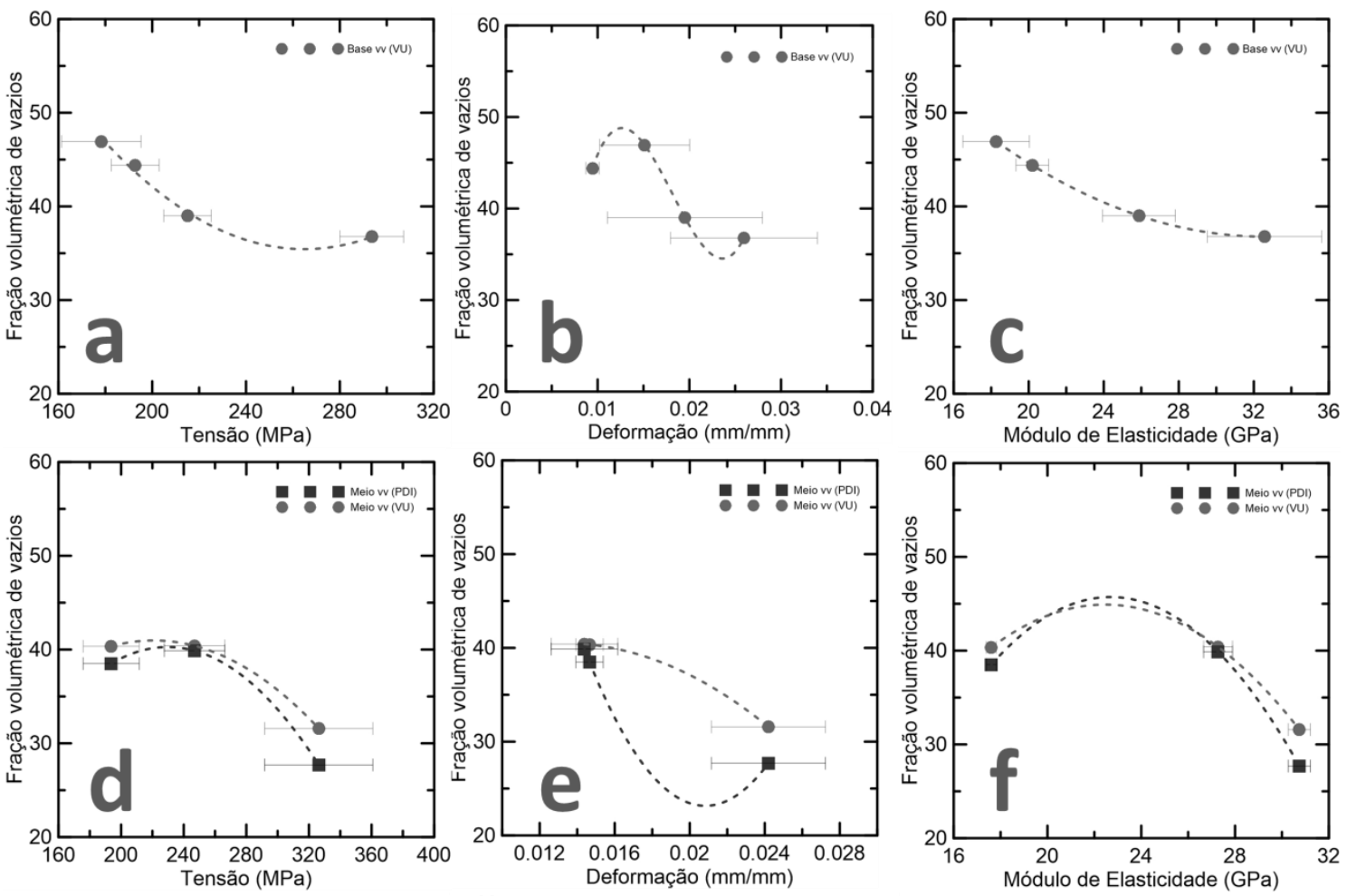

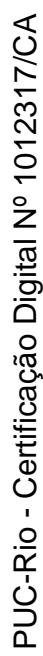
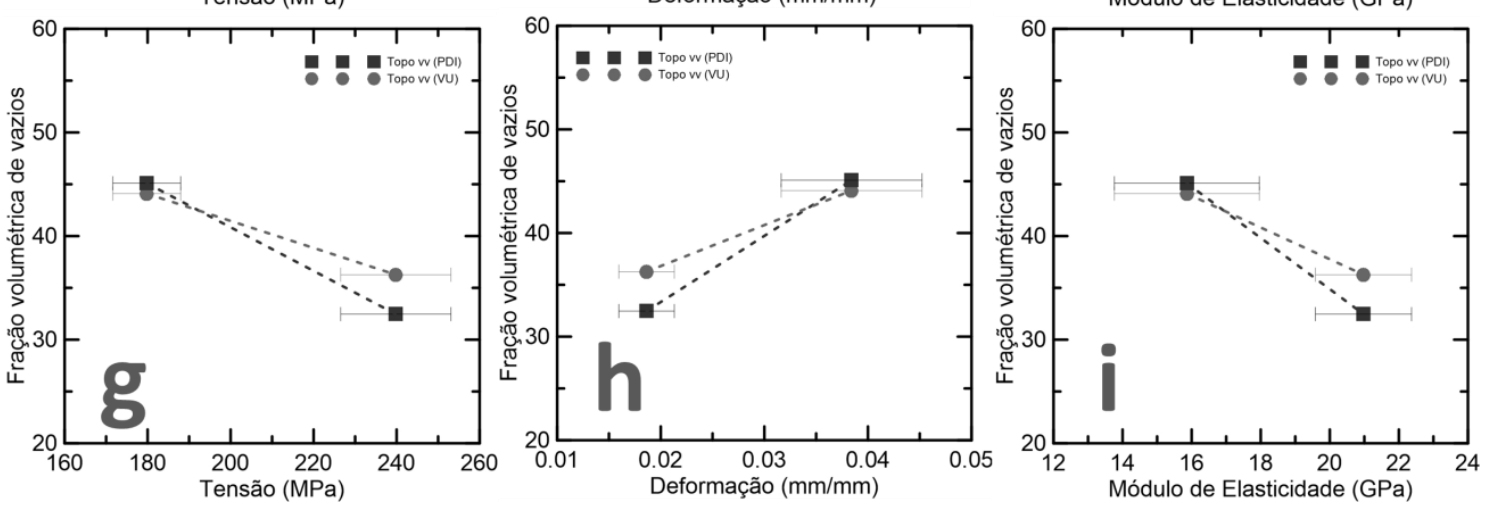

Figura 80: Relação entre a fração volumétrica de vazios obtida por PDI e pelo método proposto e: a) tensão na região basal; b) deformação na região basal; c) módulo de elasticidade na região basal; d) tensão na região medial; e) deformação na região medial; f) módulo de elasticidade na região medial; g) tensão na região apical; h) deformação na região apical e i) módulo de elasticidade na região apical.

Analisando os gráficos observa-se que a fração volumétrica de fibras influencia as propriedades com uma tendência inversamente proporcional à influência da fração de matriz. A fração de vazios, entretanto, embora se aproxime mais da influência exercida pela matriz, apresenta diferenças, notadamente no que diz respeito aos corpos-de-prova mediais centrais. Verificase baixa influência da matriz na resistência e na rigidez dos corpos-de-prova, sendo a fração de fibras determinante. Ademais, a fração volumétrica de vazios, 
6.

por ser determinante na densidade, tem grande influência nas propriedades específicas.

Infelizmente a falta de dados específicos de frações de fibras e matriz para a região basal limita a possibilidade de análise do quadro geral.

\subsubsection{Ensaios de compressão paralela às fibras}

A Tabela 20 apresenta a lista dos corpos-de-prova, seus modos de ruptura e algumas das propriedades mecânicas obtidas e a Figura 81 as curvas tensão $x$ deformação de todos os ensaios, divididas por blocos de corpos-de-prova. 
6.

Tabela 20: Lista de corpos-de-prova das regiões basal, medial e apical, provenientes das diferentes camadas da parede do colmo, descrição sumarizada dos modos de ruptura e registros de tensão máxima, deformação global máxima equivalente e modulo de elasticidade obtidos nos ensaios à compressão.

\begin{tabular}{|c|c|c|c|c|}
\hline corpos-de-prova & modo de falha & $\sigma_{\text {máx }}(\mathrm{MPa})$ & $\varepsilon_{\text {máx }}$ & E (GPa) \\
\hline BE1 & $\begin{array}{l}\text { rótulas plásticas (rp) + } \\
\text { esmagamento (esm) }\end{array}$ & 64,35 & 0,04 & 1,11 \\
\hline BME1 & esm + cisalhamento modo 1 (cis) & 58,63 & 0,13 & 0,80 \\
\hline BMI1 & $\mathrm{esm}+\mathrm{cis}+\mathrm{rp}$ & 57,57 & 0,08 & 0,39 \\
\hline BI1 & flambagem (fla) + cis & 44,96 & 0,07 & 0,36 \\
\hline BE2 & esm & 88,75 & 0,05 & 1,96 \\
\hline BME2 & $r p+e s m+c i s$ & 76,04 & 0,05 & 0,63 \\
\hline BMI2 & $\mathrm{fla}+\mathrm{cis}$ & 60,69 & 0,05 & 0,41 \\
\hline $\mathrm{B} 12$ & esm & 52,53 & 0,06 & 0,34 \\
\hline BE3 & $\mathrm{rp}$ & 109,59 & 0,04 & 3,61 \\
\hline BME3 & esm & 68,81 & 0,05 & 0,80 \\
\hline BMI3 & esm & 55,51 & 0,05 & 0,74 \\
\hline $\mathrm{B} \mid 3$ & $\mathrm{esm}+\mathrm{rp}$ & 45,38 & 0,05 & 0,54 \\
\hline BE4 & esm + cis & 105,79 & 0,04 & 2,73 \\
\hline BME4 & esm + fla & 72,69 & 0,04 & 0,53 \\
\hline BMI4 & $\mathrm{fla}+\mathrm{esm}$ & 53,53 & 0,04 & 0,32 \\
\hline B14 & esm & 48,35 & 0,07 & 0,47 \\
\hline BE5 & $\mathrm{rp}$ & 88,17 & 0,04 & 2,41 \\
\hline BME5 & esm & 71,70 & 0,04 & 0,57 \\
\hline BMI5 & fla & 64,06 & 0,07 & 0,62 \\
\hline BI5 & esm + cis & 60,15 & 0,09 & 0,50 \\
\hline ME1 & fla & 94,76 & 0,07 & 0,94 \\
\hline MM1 & esm & 70,94 & 0,06 & 0,65 \\
\hline MI1 & esm & 67,35 & 0,06 & 0,42 \\
\hline ME2 & esm & 101,37 & 0,08 & 0,63 \\
\hline MM2 & fla & 76,68 & 0,07 & 0,85 \\
\hline MI2 & $e s m+r p$ & 61,25 & 0,08 & 0,45 \\
\hline ME3 & $\mathrm{fla}+$ cis & 99,63 & 0,08 & 0,50 \\
\hline MM3 & $\mathrm{rp}$ & 80,13 & 0,05 & 0,77 \\
\hline MI3 & $\mathrm{esm}+\mathrm{rp}$ & 66,62 & 0,05 & 1,36 \\
\hline ME4 & fla & 98,83 & 0,09 & 0,41 \\
\hline MM4 & $\mathrm{fla}+\mathrm{cis}$ & 73,42 & 0,07 & 0,52 \\
\hline MI4 & $\mathrm{rp}$ & 72,98 & 0,05 & 0,68 \\
\hline ME5 & $\mathrm{fla}+\mathrm{cis}$ & 79,15 & 0,08 & 0,99 \\
\hline MM5 & fla & 67,44 & 0,08 & 0,70 \\
\hline MI5 & $\mathrm{esm}+\mathrm{rp}$ & 68,13 & 0,10 & 0,35 \\
\hline TE1 & fla & 91,81 & 0,05 & 1,45 \\
\hline TI1 & fla & 78,40 & 0,12 & 0,61 \\
\hline TE2 & fla & 97,25 & 0,06 & 0,42 \\
\hline $\mathrm{TI2}$ & $\mathrm{rp}$ & 79,28 & 0,08 & 0,40 \\
\hline TE3 & fla & 94,94 & 0,08 & 1,60 \\
\hline $\mathrm{TI3}$ & fla + cis & 78,37 & 0,05 & 0,80 \\
\hline TE4 & fla & 101,67 & 0,07 & 0,58 \\
\hline TI4 & fla & 78,42 & 0,05 & 0,78 \\
\hline TE5 & fla & 101,13 & 0,04 & 2,90 \\
\hline TI5 & $e s m+r p$ & 77,44 & 0,05 & 0,78 \\
\hline
\end{tabular}


6.
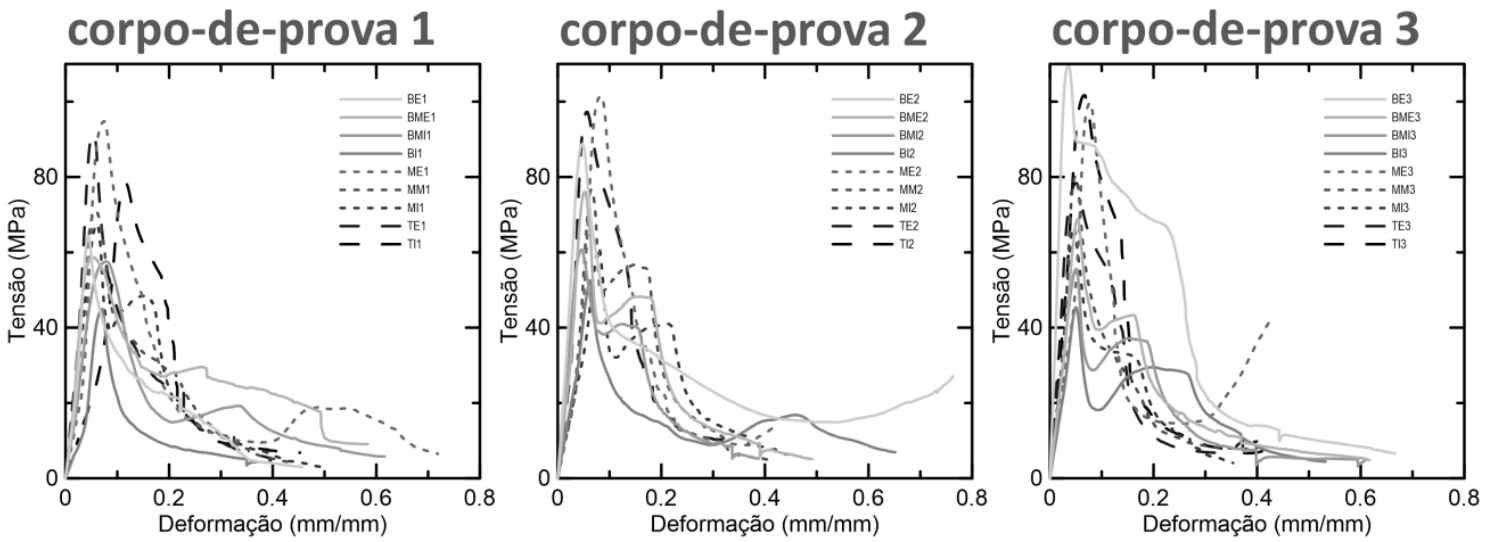

\section{corpo-de-prova 4}

corpo-de-prova 5
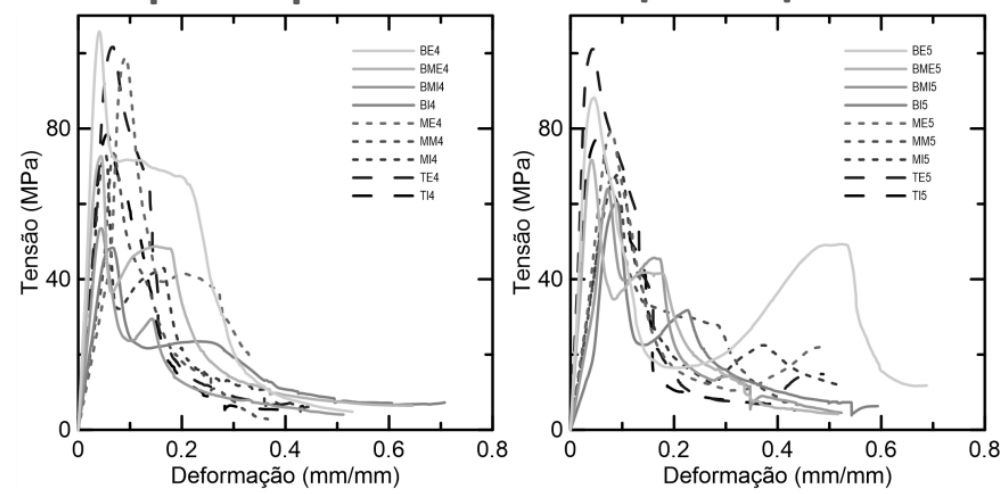

Figura 81: Curvas tensão deformação das diferentes camadas e porções do colmo, separadas por blocos de corpos-de-prova.

Para facilitar o entendimento, um resumo com as médias e desvios padrão dos resultados e curvas representativas dos ensaios estão consolidados abaixo na Tabela 21 e na Figura 75.

Tabela 21: Médias e desvios padrão das tensões máximas, deformações máximas equivalentes (computadas quando da tensão máxima) e módulos de elasticidade, obtidas pelos corpos-de-prova ensaiados à compressão, bem como suas propriedades específicas.

\begin{tabular}{|l|r|r|r|r|r|r|r|r|r|r|r|}
\hline \multirow{2}{*}{ corpos-de-prova } & \multicolumn{2}{|c|}{$V_{\text {med/std }}$} & \multicolumn{2}{c|}{$\sigma_{\text {med/std }}$} & \multicolumn{2}{c|}{$\varepsilon_{\text {med/std }}$} & \multicolumn{2}{c|}{$E_{\text {med/std }}$} & \multicolumn{2}{c|}{$\sigma / \gamma$} & \multicolumn{1}{c|}{$\mathrm{E} / \mathrm{V}$} \\
\hline BE & 0,91 & 0,06 & 91,33 & 16,05 & 0,04 & 0,00 & 2,36 & 0,82 & 100,68 & 2,61 \\
\hline BME & 0,78 & 0,02 & 69,57 & 5,94 & 0,06 & 0,03 & 0,67 & 0,12 & 88,77 & 0,85 \\
\hline BMI & 0,64 & 0,02 & 58,27 & 3,74 & 0,06 & 0,01 & 0,50 & 0,16 & 91,74 & 0,78 \\
\hline BI & 0,66 & 0,03 & 50,27 & 5,63 & 0,07 & 0,01 & 0,44 & 0,08 & 76,58 & 0,67 \\
\hline ME & 0,94 & 0,01 & 94,75 & 8,09 & 0,08 & 0,01 & 0,69 & 0,23 & 100,77 & 0,74 \\
\hline MM & 0,78 & 0,02 & 73,72 & 4,41 & 0,07 & 0,01 & 0,70 & 0,11 & 94,85 & 0,90 \\
\hline MI & 0,71 & 0,02 & 67,27 & 3,74 & 0,07 & 0,02 & 0,65 & 0,37 & 94,14 & 0,91 \\
\hline TE & 1,00 & 0,02 & 97,36 & 3,73 & 0,06 & 0,01 & 1,39 & 0,89 & 97,08 & 1,38 \\
\hline TI & 0,92 & 0,01 & 78,38 & 0,58 & 0,07 & 0,02 & 0,67 & 0,16 & 84,77 & 0,73 \\
\hline
\end{tabular}


6.
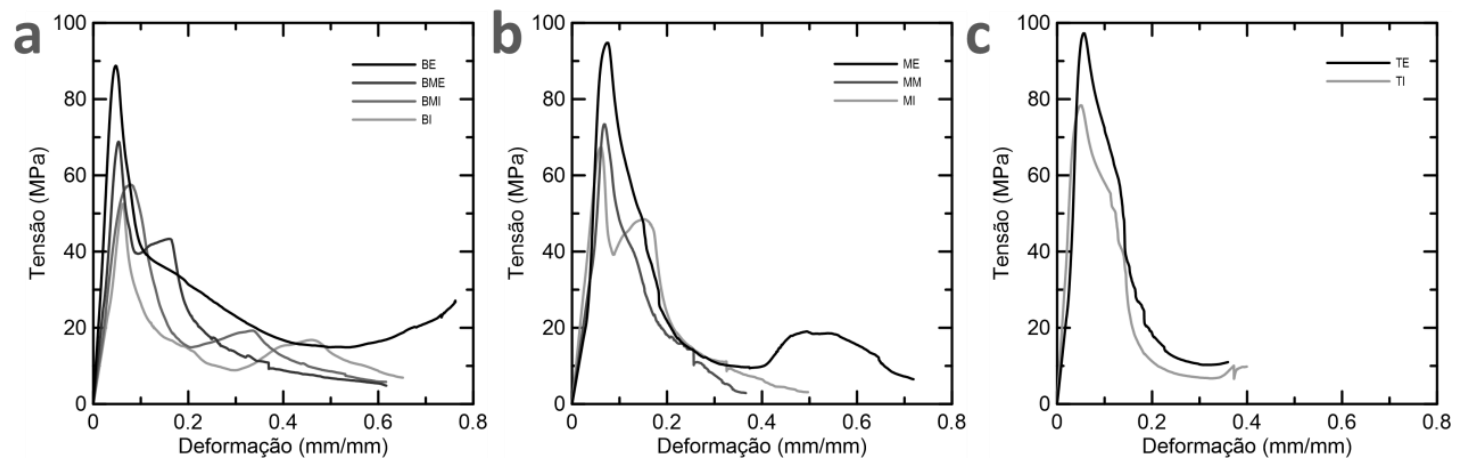

Figura 82: Gráficos tensão $\mathrm{x}$ deformação de curvas representativas de corpos-deprova provenientes dos diferentes pontos das paredes das porções de colmo: a) basal; b) medial e c) apical.

De um modo geral os resultados dos ensaios são bastante homogêneos. No caso, como a largura dos corpos-de-prova é padronizada, não ocorre uma variação de rigidez referente à diferença entre geometrias, como observado anteriormente para os ensaios de controle. Os corpos-de-prova provenientes das camadas externas da parede apresentaram resultados bastante próximos, independente da porção do colmo de onde foram extraídos, apresentando um leve incremento da base para o topo. Seria esperado que as camadas internas também respeitassem essa lógica, no entanto, os resultados que parecem regular entre si são os da camada medial externa basal, camada medial central e camada interna apical. De maneira similar, regulam em relação à tensão máxima as camadas medial interna basal e interna central, sendo a camada interna basal a que apresenta a menor resistência entre todas.

Os modos de ruptura observados foram similares aos verificados para os ensaios de controle, podendo ser classificados em 4 Grupos (Figura 83), mais um quinto que engloba modos de falha associados entre os descritos. 
6.

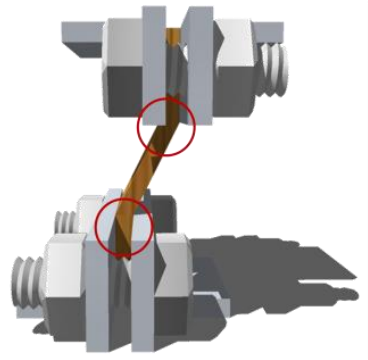

Grupo 1

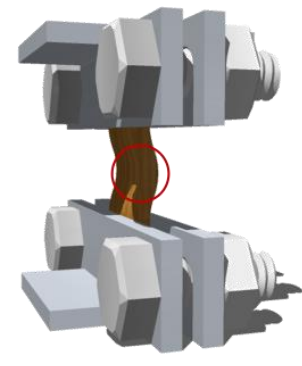

Grupo 2

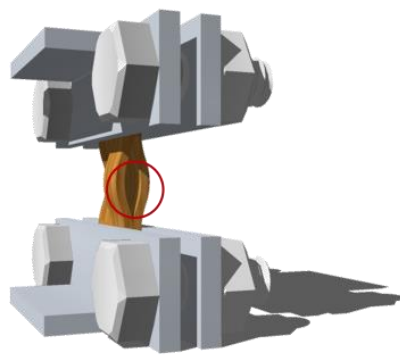

Grupo 3

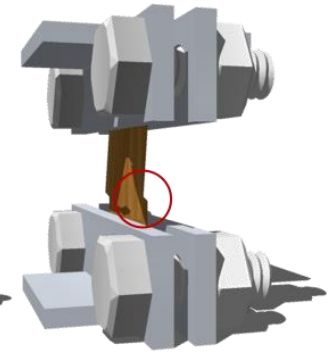

Grupo 4

Figura 83: Ilustração dos modos de ruptura observados nos ensaios à tração de lâminas procedentes de diferentes posições da parede e porções do colmo de bambu da espécie Dendrocalamus giganteus.

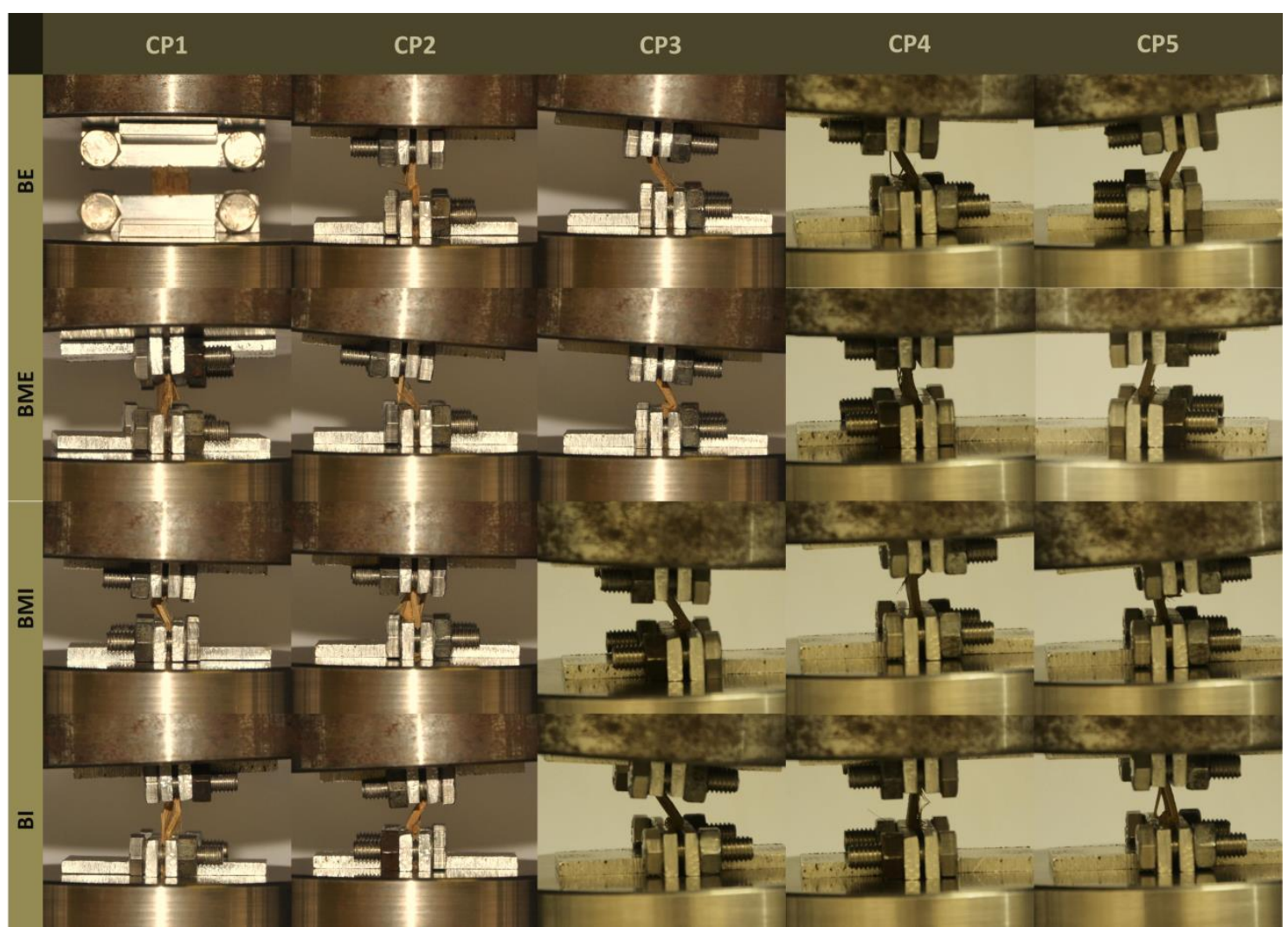

Figura 84: Modos de falha dos corpos-de-prova de compressão. Cada bloco numerado (CP) provem de uma mesma régua da região basal, dividida em sua espessura.

Avaliando a dispersão de modos de ruptura por porção do colmo verifica-se que, na porção basal (Figura 84), a falha dominante é por esmagamento, seja puro ou associado a outros modos, representando $75 \%$ do total, dos quais $30 \%$ compatíveis com o Grupo 4 e $45 \%$ compostos por modos de falha mistos, envolvendo predominantemente cisalhamento. 
6.

Em uma abordagem mais específica: para a camada externa, 60\% das falhas envolveram esmagamento, $60 \%$ apresentaram formação de rótulas plásticas e $20 \%$ cisalhamento; para a posição medial externa: $100 \%$ envolveram esmagamento, $40 \%$ envolveram cisalhamento, $20 \%$ flambagem e $20 \%$ rótulas plásticas; para a região medial interna: 60\% esmagamento, 60\% flambagem, $40 \%$ cisalhamento e 20\% rótulas plásticas e para a camada interna: $80 \%$ apresentam falha por esmagamento, $40 \%$ por cisalhamento, $20 \%$ por cisalhamento e $20 \%$ por rótulas plásticas.

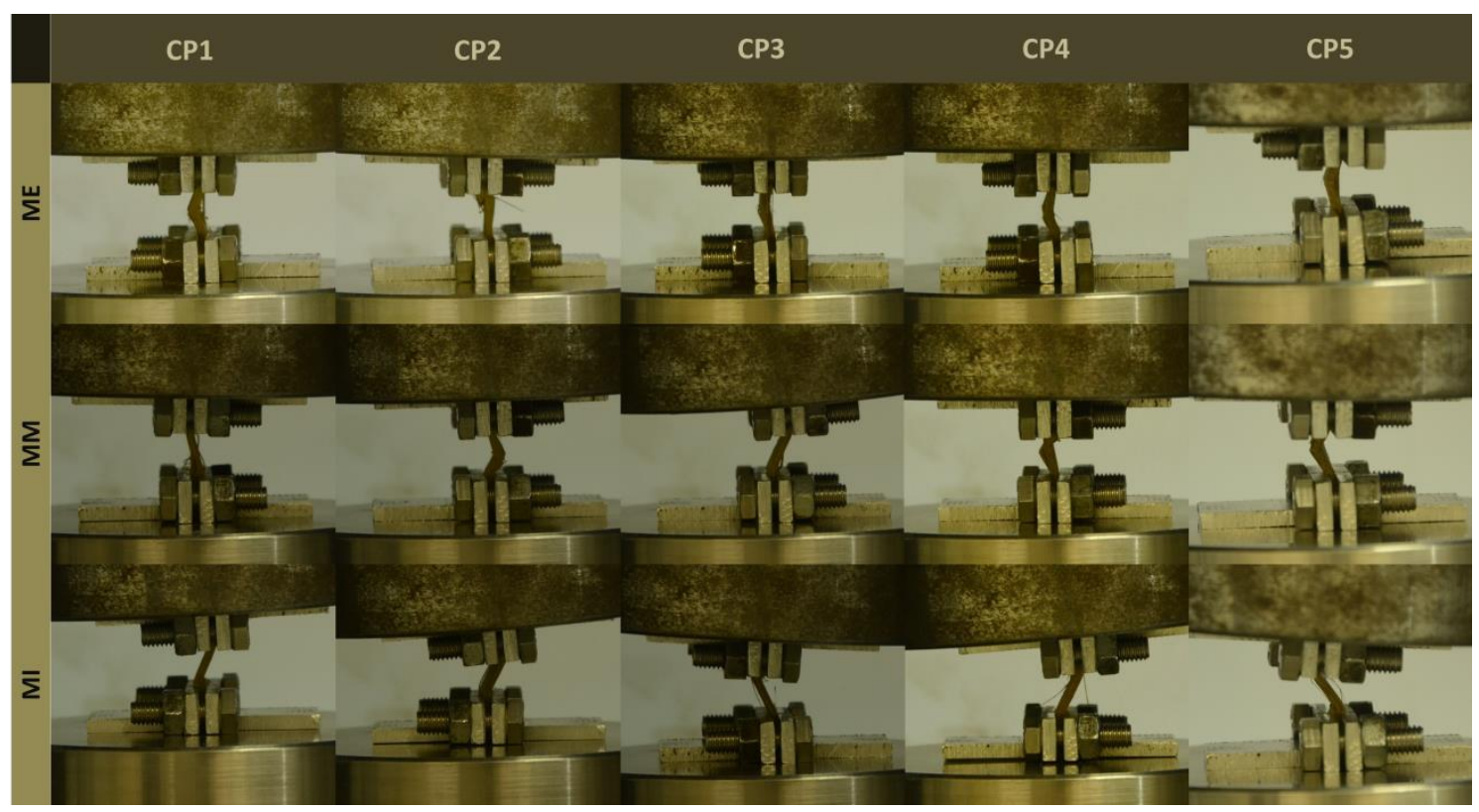

Figura 85: Modos de falha dos corpos-de-prova de compressão. Cada bloco numerado (CP) provem de uma mesma régua da região central, dividida em sua espessura.

No que diz respeito aos corpos-de-prova da porção central do colmo (Figura 85 ), 40\% falham por esmagamento, sendo $20 \%$ associados a outros modos, predominantemente rótulas plásticas. 46,7\% falham por flambagem, dos quais $26,7 \%$ Grupo 2 e 20\% Grupo 3. Especificamente, a camada externa é dominada por flambagem, que representa $80 \%$ da razão das falhas, $40 \%$ cisalhamento e $20 \%$ esmagamento. A camada intermediária apresenta $60 \%$ das rupturas por flambagem, $20 \%$ por esmagamento, 20\% por rótulas plásticas e $20 \%$ por cisalhamento. $\mathrm{Na}$ camada interna $80 \%$ esmagamento e $80 \%$ rótulas plásticas. 
6.

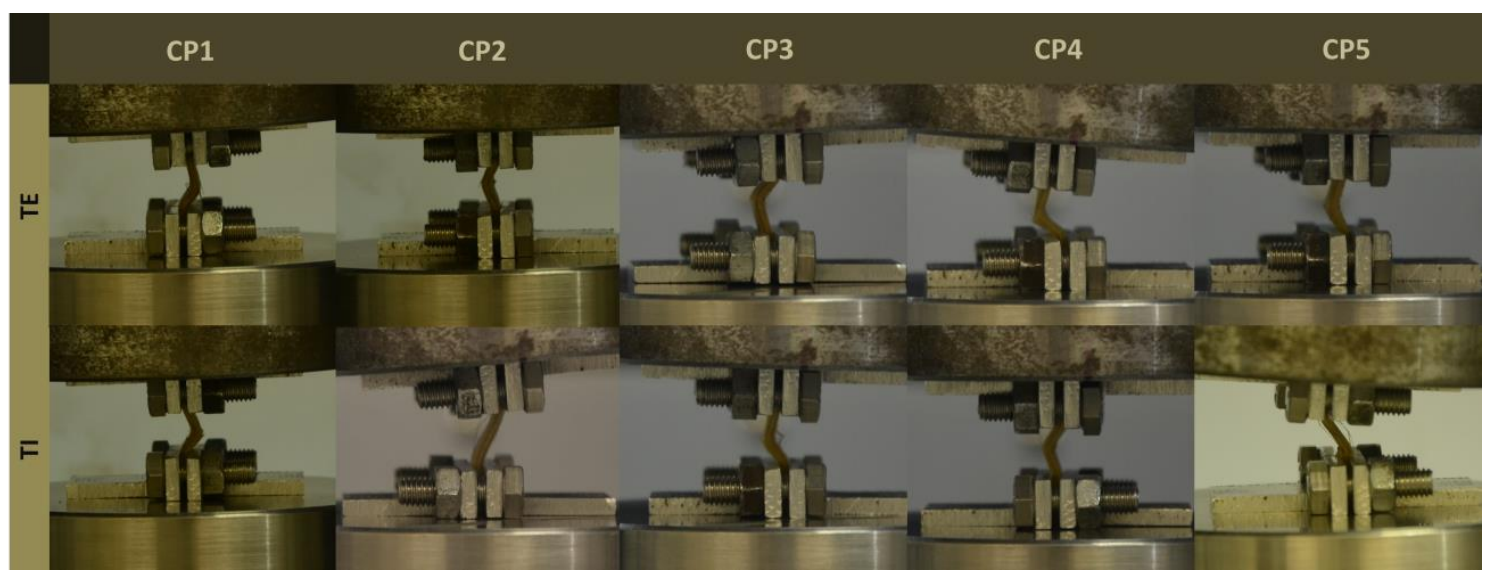

Figura 86: Modos de falha dos corpos-de-prova de compressão. Cada bloco numerado (CP) provem de uma mesma régua da região apical, dividida em sua espessura.

$\mathrm{Na}$ região apical (Figura 86) o modo de ruptura dominante é por flambagem, que participa de $80 \%$ das falhas, entre as quais $70 \%$ consistentes com o Grupo 2 e 10\% com o Grupo 3. Rótulas plásticas são formadas em 20\% das rupturas, $10 \%$ falham por cisalhamento e $10 \%$ por esmagamento. Todas as amostras da camada externa caracterizam-se por falha condizente com o Grupo 2. Na camada interna 40\% de falhas Grupo 2, 20\% Grupo 3, 20\% Grupo 1 e 20 \% Grupo 5, com ruptura composta por esmagamento com formação de rótulas plásticas.

Em geral, materiais compósitos tem resistência à compressão dependente da fração volumétrica dos constituintes e da maneira como é feito o seu empacotamento. Altas frações volumétricas de fibras fazem com que as propriedades sejam ditadas pelo reforço, mas para frações mais baixas a matriz passa a ser dominante, dados que as fibras passam a apresentar grande instabilidade. É importante notar que a microestrutura da matriz do material em estudo, embora muito porosa, possui uma compleição morfológica de alta rigidez, sendo formada por tubos prismáticos de parede fina, colados entre si e com reforços periódicos transversais, fatores que diminuem consideravelmente efeitos de instabilidade.

A Figura 87, a Figura 88 e a Figura 89 comparam respectivamente frações volumétricas de fibras, matriz e vazios com propriedades mecânicas obtidas nos ensaios à compressão. 
6.
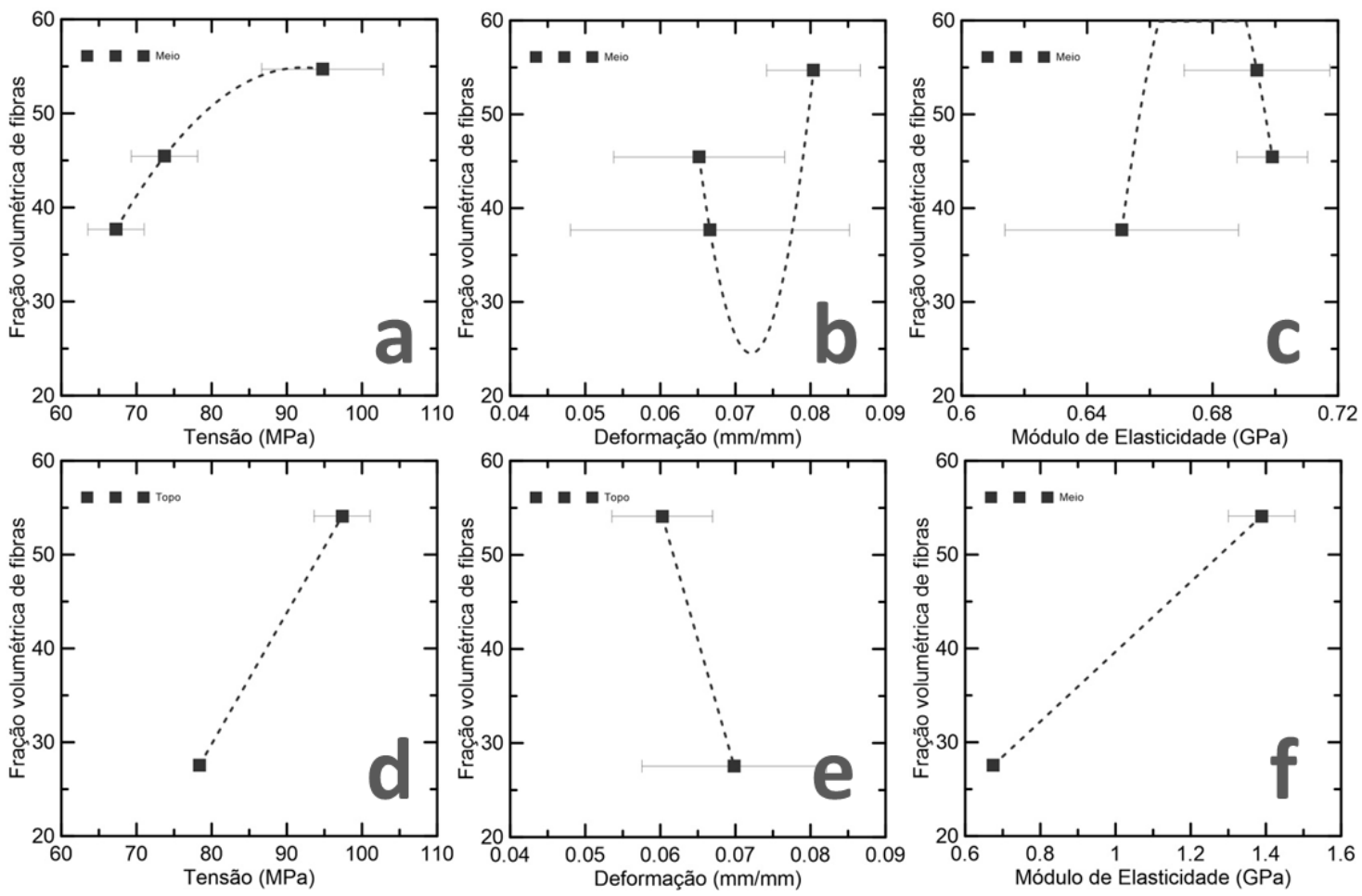

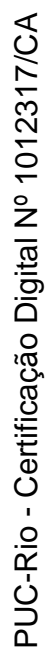

Figura 87: Relação entre a fração volumétrica de fibras e: a) tensão na região central; b) deformação na região central; c) módulo de elasticidade na região central; d) tensão na região apical; e) deformação na região apical e f) módulo de elasticidade na região apical.
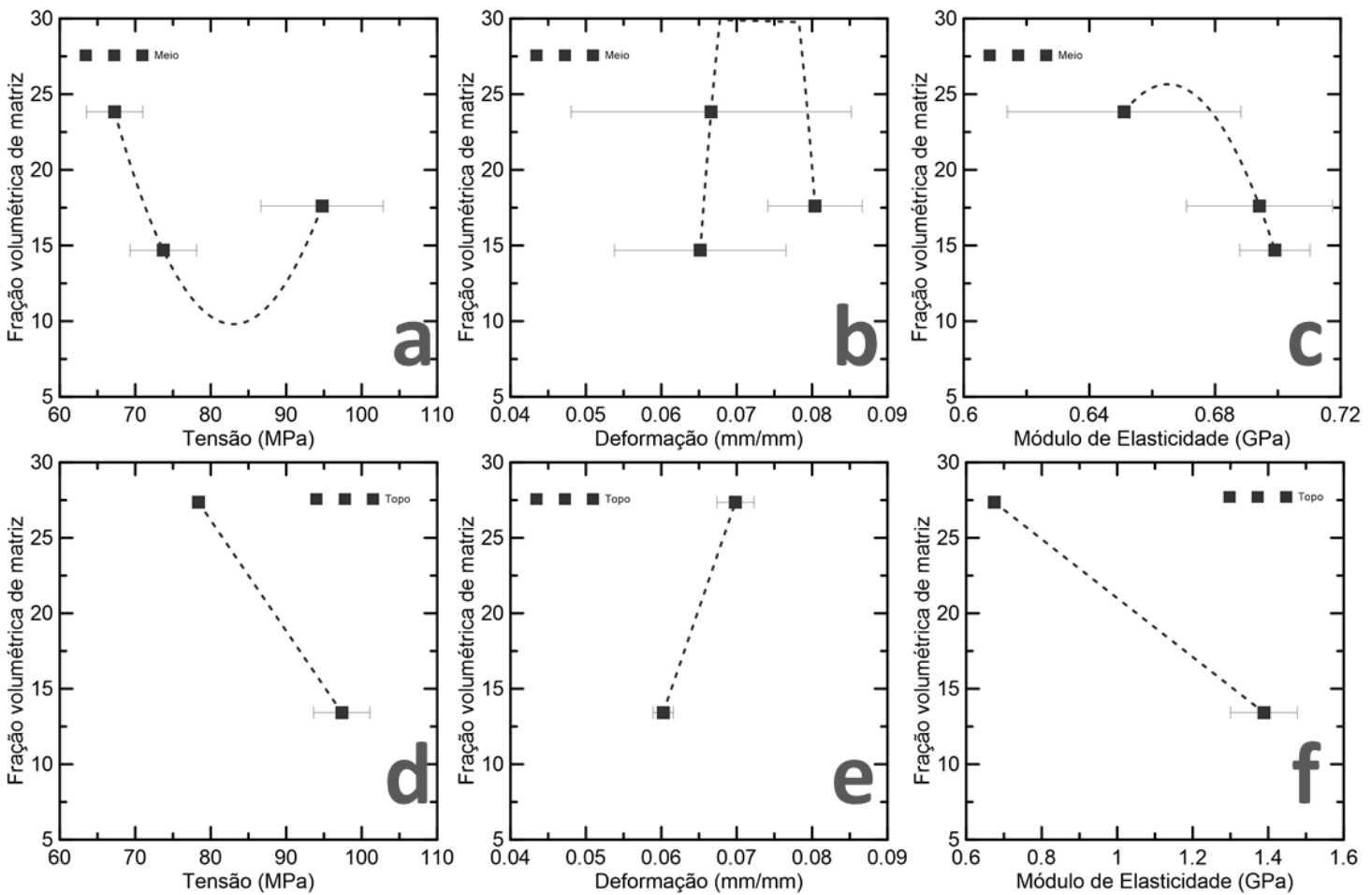

Figura 88: Relação entre a fração volumétrica de matriz e: a) tensão na região central; b) deformação na região central; c) módulo de elasticidade na região central; d) tensão na região apical; e) deformação na região apical e f) módulo de elasticidade na região apical. 
6.
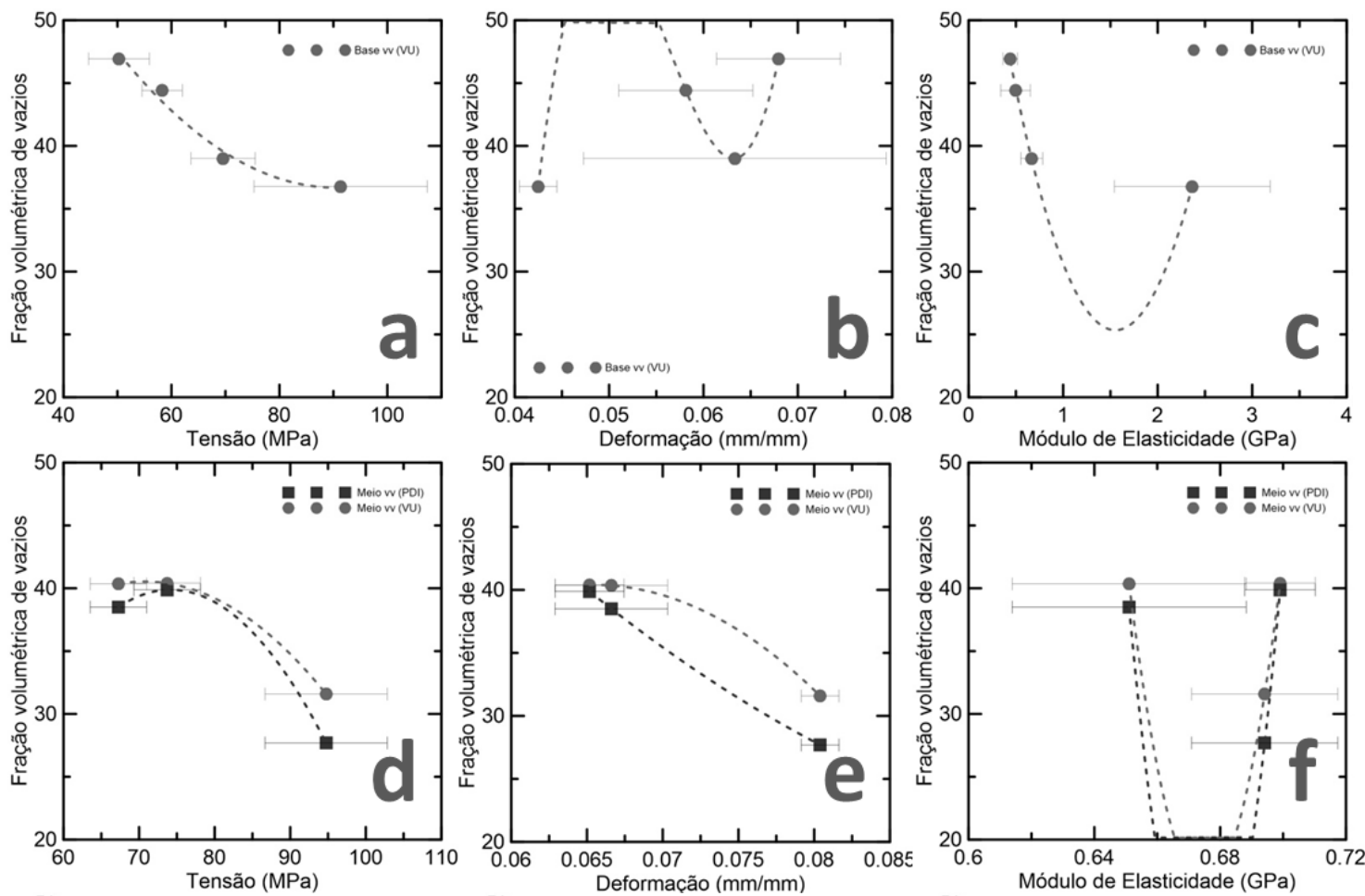

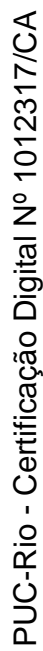
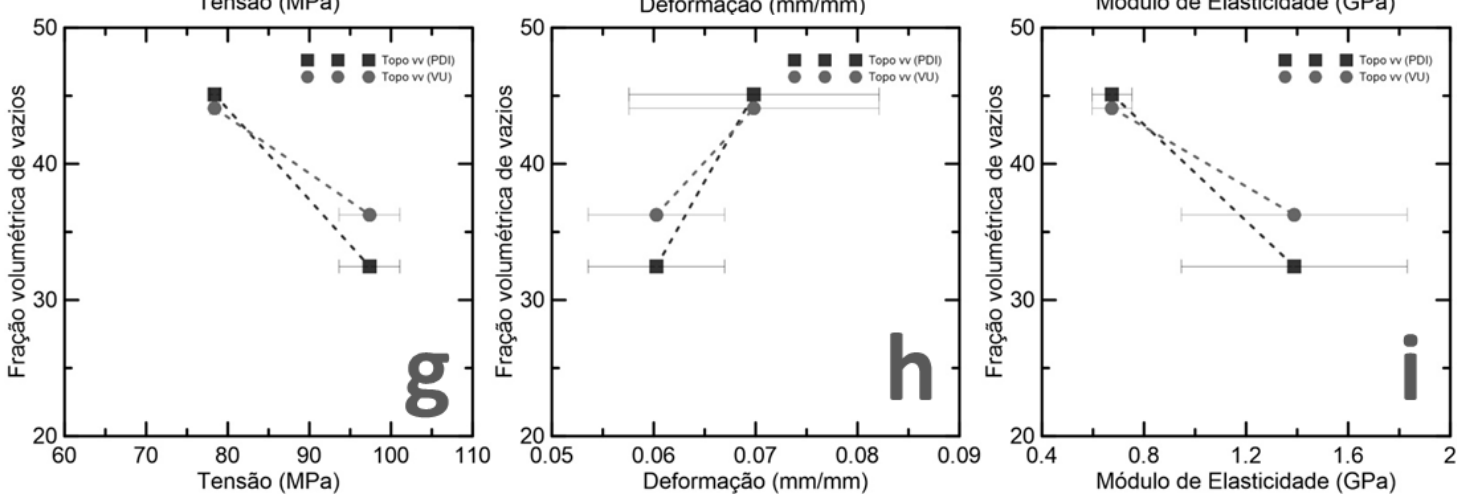

Figura 89: Relação entre a fração volumétrica de vazios obtida por PDI e pelo método proposto e: a) tensão na região basal; b) deformação na região basal; c) módulo de elasticidade na região basal; d) tensão na região medial; e) deformação na região medial; f) módulo de elasticidade na região medial; g) tensão na região apical; h) deformação na região apical e i) módulo de elasticidade na região apical.

Analisando-se as curvas percebe-se que há uma relação de dependência entre a fração volumétrica de fibras e a tensão máxima a compressão, entretanto, ao verificar os valores relativos ao módulo de elasticidade, percebese que esta relação não é direta. Percebe-se também influência entre a diminuição do teor de vazios e o aumento da resistência e da rigidez, muito embora esta análise precise ser feita consorciando as observações relativas às frações volumétricas de reforço, dado que as nuvens de pontos para os módulos de elasticidade nas regiões basal e central apresentam concentrações específicas tanto na ordenada como na abcissa. Isto é, ocorrem pontos nos 
6.

quais a rigidez varia muito para frações volumétrica muito similares de vazios e outros em que frações muito dispares de vazios estão relacionadas a uma rigidez muito semelhante. A matriz apresenta influência minoritária nas propriedades.

\subsubsection{Ensaios de cisalhamento (compressão 45)}

A Tabela 22 apresenta a lista dos corpos-de-prova, seus modos de ruptura e algumas das propriedades mecânicas obtidas e a Figura 90 as curvas tensão $x$ deformação de todos os ensaios, divididas por blocos de corpos-de-prova. 
6.

Tabela 22: Lista de corpos-de-prova das regiões basal, medial e apical, provenientes das diferentes camadas da parede do colmo, com informações gerais imediatamente anteriores ao ensaio, descrição sumarizada dos modos de ruptura e registros de tensão máxima, deformação global máxima equivalente e modulo de elasticidade obtidos nos ensaios ao cisalhamento.

\begin{tabular}{|c|c|c|c|c|c|c|c|}
\hline corpos-de-prova & $\begin{array}{c}\text { volume } \\
\text { (cm3) }\end{array}$ & $\begin{array}{c}\text { massa } \\
\text { (g) }\end{array}$ & $\begin{array}{c}\text { densidade } \\
\text { (g/cm3) }\end{array}$ & modo de falha & $\tau_{\text {máx }}$ & $\varepsilon_{\text {máx }}$ & G \\
\hline BE1 & 0,39 & 0,24 & 0,62 & flambagem (fla) & 20,01 & 0,25 & 0,13 \\
\hline BME1 & 0,33 & 0,19 & 0,57 & $\begin{array}{l}\text { cisalhamento } \\
\text { modo } 2 \text { (cis) }\end{array}$ & 11,63 & 0,25 & 0,07 \\
\hline BMI1 & 0,33 & 0,16 & 0,48 & fla + cis & 9,05 & 0,28 & 0,05 \\
\hline BI1 & 0,34 & 0,17 & 0,51 & $\begin{array}{l}\text { deslizamento na } \\
\text { pinça (des) + cis }\end{array}$ & 4,64 & 0,17 & 0,03 \\
\hline BE2 & 0,34 & 0,22 & 0,67 & cis & 9,30 & 0,23 & 0,07 \\
\hline BME2 & 0,35 & 0,20 & 0,58 & des + fla + cis & 5,92 & 0,12 & 0,06 \\
\hline BMI2 & 0,35 & 0,17 & 0,48 & des + cis & 7,49 & 0,25 & 0,04 \\
\hline $\mathrm{B} 12$ & 0,36 & 0,18 & 0,50 & cis & 6,62 & 0,22 & 0,04 \\
\hline BE3 & 0,36 & 0,23 & 0,63 & fla + cis & 12,64 & 0,19 & 0,07 \\
\hline BME3 & 0,34 & 0,20 & 0,58 & cis & 10,05 & 0,19 & 0,06 \\
\hline BMI3 & 0,33 & 0,16 & 0,49 & cis & 8,94 & 0,27 & 0,04 \\
\hline $\mathrm{BI3}$ & 0,34 & 0,18 & 0,52 & cis & 7,95 & 0,26 & 0,03 \\
\hline BE4 & 0,35 & 0,22 & 0,64 & fla + cis & 11,23 & 0,18 & 0,09 \\
\hline BME4 & 0,37 & 0,21 & 0,57 & cis & 11,14 & 0,18 & 0,08 \\
\hline BMI4 & 0,34 & 0,16 & 0,47 & des + cis & 6,22 & 0,22 & 0,04 \\
\hline BI4 & 0,37 & 0,18 & 0,49 & cis & 9,55 & 0,31 & 0,04 \\
\hline BE5 & 0,35 & 0,22 & 0,64 & des + cis & 8,81 & 0,31 & 0,04 \\
\hline BME5 & 0,36 & 0,20 & 0,56 & fla + cis & 10,34 & 0,20 & 0,07 \\
\hline BMI5 & 0,33 & 0,15 & 0,46 & cis & 7,08 & 0,28 & 0,04 \\
\hline BI5 & 0,35 & 0,18 & 0,52 & fla + des & 6,16 & 0,20 & 0,04 \\
\hline ME1 & 0,35 & 0,23 & 0,67 & des + cis & 8,02 & 0,11 & 0,08 \\
\hline MM1 & 0,37 & 0,23 & 0,63 & cis & 10,20 & 0,16 & 0,07 \\
\hline MI1 & 0,32 & 0,17 & 0,53 & fla + cis & 8,56 & 0,15 & 0,06 \\
\hline ME2 & 0,33 & 0,23 & 0,70 & cis & 13,83 & 0,15 & 0,09 \\
\hline MM2 & 0,36 & 0,23 & 0,65 & cis & 11,56 & 0,16 & 0,08 \\
\hline MI2 & 0,31 & 0,17 & 0,55 & cis & 10,50 & 0,13 & 0,10 \\
\hline ME3 & 0,35 & 0,24 & 0,69 & fla + cis & 13,62 & 0,12 & 0,16 \\
\hline MM3 & 0,37 & 0,24 & 0,64 & cis & 10,36 & 0,15 & 0,08 \\
\hline MI3 & 0,30 & 0,17 & 0,56 & des + cis & 9,24 & 0,15 & 0,07 \\
\hline ME4 & 0,33 & 0,24 & 0,72 & cis & 14,25 & 0,20 & 0,07 \\
\hline MM4 & 0,36 & 0,23 & 0,63 & des + cis & 11,53 & 0,13 & 0,10 \\
\hline MI4 & 0,32 & 0,17 & 0,53 & fla + cis & 7,08 & 0,13 & 0,07 \\
\hline ME5 & 0,34 & 0,23 & 0,67 & des + fla & 13,44 & 0,15 & 0,10 \\
\hline MM5 & 0,35 & 0,22 & 0,63 & des + fla & 10,64 & 0,15 & 0,09 \\
\hline MI5 & 0,31 & 0,17 & 0,54 & des + fla & 9,43 & 0,17 & 0,06 \\
\hline TE1 & 0,34 & 0,26 & 0,76 & des + cis & 10,38 & 0,26 & 0,07 \\
\hline TI1 & 0,36 & 0,24 & 0,65 & des & 12,64 & 0,24 & 0,10 \\
\hline TE2 & 0,34 & 0,25 & 0,74 & des & 13,21 & 0,26 & 0,07 \\
\hline $\mathrm{T} 12$ & 0,37 & 0,23 & 0,62 & fla + cis & 18,18 & 0,21 & 0,09 \\
\hline TE3 & 0,37 & 0,26 & 0,71 & cis & 21,59 & 0,16 & 0,17 \\
\hline TI3 & 0,37 & 0,23 & 0,64 & cis & 17,36 & 0,19 & 0,08 \\
\hline TE4 & 0,34 & 0,25 & 0,72 & cis & 17,69 & 0,19 & 0,10 \\
\hline $\mathrm{TI} 4$ & 0,37 & 0,24 & 0,64 & cis & 17,51 & 0,19 & 0,10 \\
\hline TE5 & 0,37 & 0,24 & 0,64 & cis & 16,96 & 0,17 & 0,11 \\
\hline TI5 & 0,36 & 0,23 & 0,65 & cis & 14,46 & 0,19 & 0,07 \\
\hline
\end{tabular}


6.

corpo-de-prova 1

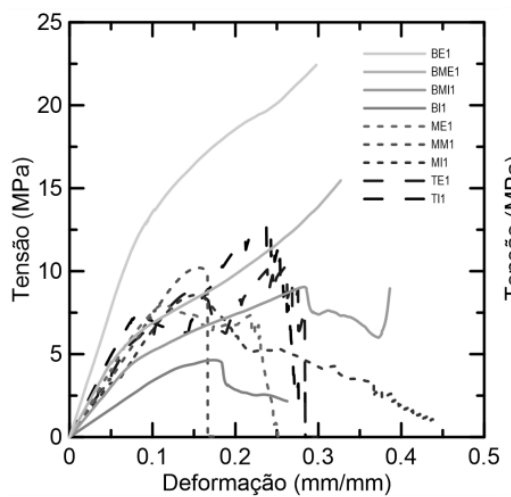

corpo-de-prova 2

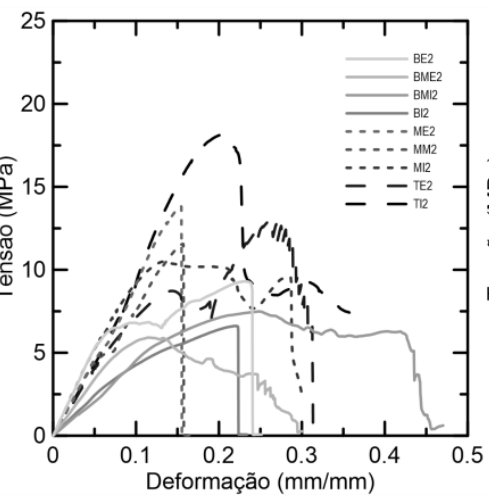

corpo-de-prova 3

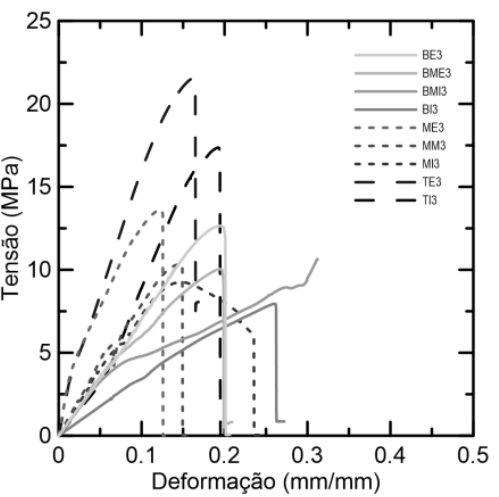

corpo-de-prova 4

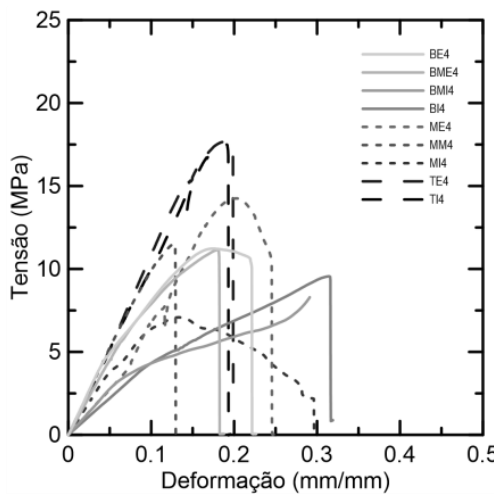

corpo-de-prova 5

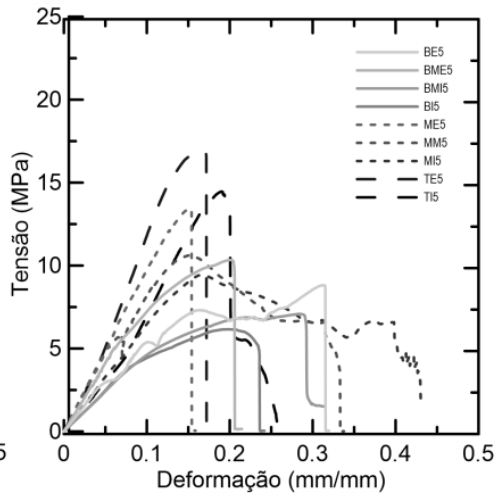

Figura 90: Curvas tensão deformação das diferentes camadas e porções do colmo, separadas por blocos de corpos-de-prova.

No intuito de facilitar a compreensão, um resumo com as médias e desvios padrão dos resultados e curvas representativas dos ensaios estão consolidados abaixo respectivamente na Tabela 23 e na Figura 91.

Tabela 23: Médias e desvios padrão das tensões máximas, deformações máximas equivalentes (computadas quando da tensão máxima) e módulos de elasticidade, obtidas pelos corpos-de-prova ensaiados ao cisalhamento, bem como suas propriedades específicas.

\begin{tabular}{|c|c|c|c|c|c|c|c|c|c|c|}
\hline \multirow{2}{*}{$\begin{array}{l}\text { corpos-de-prova } \\
\text { BE }\end{array}$} & \multicolumn{2}{|c|}{$Y_{\text {med/std }}$} & \multicolumn{2}{|c|}{$\tau_{\text {med/std }}$} & \multicolumn{2}{|c|}{$\varepsilon_{\text {med/std }}$} & \multicolumn{2}{|c|}{$\mathbf{G}_{\text {med/std }}$} & \multirow{2}{*}{$\frac{\tau / \boldsymbol{V}}{19,37}$} & \multirow{2}{*}{$\frac{\mathbf{G} / \mathbf{V}}{0,12}$} \\
\hline & 0,64 & 0,02 & 12,40 & 4,05 & 0,23 & 0,05 & 0,08 & 0,03 & & \\
\hline BME & 0,57 & 0,01 & 9,81 & 2,03 & 0,19 & 0,04 & 0,07 & 0,01 & 17,14 & 0,12 \\
\hline BMI & 0,48 & 0,01 & 7,76 & 1,09 & 0,26 & 0,02 & 0,04 & 0,00 & 16,28 & 0,09 \\
\hline BI & 0,51 & 0,01 & 6,98 & 1,66 & 0,23 & 0,05 & 0,04 & 0,00 & 13,79 & 0,07 \\
\hline $\mathrm{ME}$ & 0,69 & 0,02 & 12,63 & 2,32 & 0,15 & 0,03 & 0,10 & 0,03 & 18,33 & 0,14 \\
\hline MM & 0,64 & 0,01 & 10,86 & 0,58 & 0,15 & 0,01 & 0,08 & 0,01 & 17,10 & 0,13 \\
\hline MI & 0,54 & 0,01 & 8,96 & 1,13 & 0,15 & 0,01 & 0,07 & 0,01 & 16,54 & 0,13 \\
\hline TE & 0,72 & 0,04 & 15,97 & 3,86 & 0,21 & 0,05 & 0,11 & 0,03 & 22,28 & 0,15 \\
\hline TI & 0,64 & 0,01 & 16,03 & 2,12 & 0,20 & 0,02 & 0,09 & 0,01 & 24,97 & 0,14 \\
\hline
\end{tabular}


6.
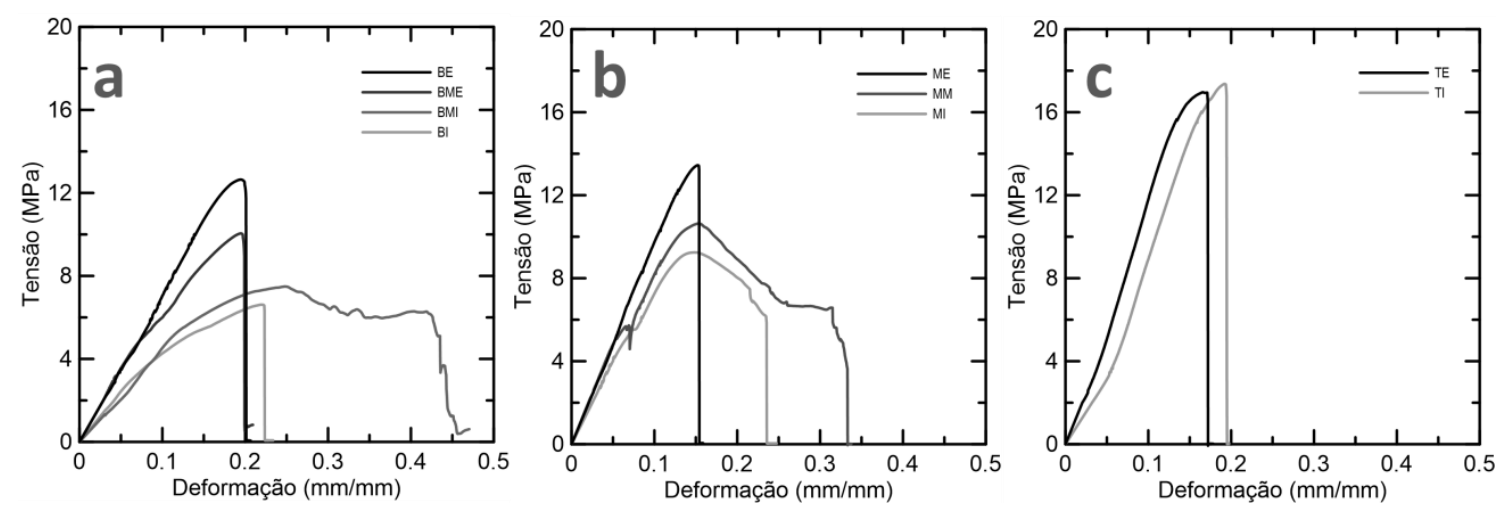

Figura 91: Gráficos tensão x deformação de curvas representativas de corpos-deprova provenientes dos diferentes pontos das paredes das porções de colmo: a) basal; b) medial e c) apical.

As propriedades mecânicas sofrem um incremento não linear, da região basal até a apical. No que diz respeito à variação da posição na parede, de uma maneira geral a resistência e a rigidez aumentam no sentido radial, da camada mais interna à camada mais externa da parede do colmo, exceto pela região apical, que apresenta médias inconsistentes com esta lógica.

Os modos de ruptura observados podem ser classificados em grupos principais:

Grupo 1: cisalhamento tipo 2 (deslizamento). Este é o modo desejável de ruptura para este tipo de ensaio, caracteriza-se por uma falha, geralmente brusca, na diagonal principal do corpo-de-prova, podendo eventualmente ser deslocada da região central, se associada a outros modos de ruptura;

Grupo 2: flambagem. Dada a esbeltez do corpo-de-prova associada a um setup rotulado, como o caso, é comum haver pequenas falhas de posicionamento que podem levar a uma inclinação da plataforma de compressão, provocando excentricidade no carregamento e incorrendo nesse tipo de falha;

Grupo 3: Deslizamento na garra posicionadora. Este modo de falha é intrinsecamente ligado à qualidade da garra posicionadora e à espessura do corpo-de-prova. Eventualmente, caso a lâmina a ser ensaiada seja muito fina, a garra pode não pinçá-la adequadamente. Ainda, com o decorrer de diversos ensaios a garra pode se deformar, tornando o espaço disponível maior do que deveria para pinçar adequadamente os corpos-de-prova;

Grupo 4: associações entre os demais. 
6.

Analisando as falhas ocorridas nas diferentes porções do colmo e camadas da parede verifica-se que a grande maioria rompeu total ou parcialmente por cisalhamento.

Na porção basal (Figura 92) $45 \%$ das falhas ocorreram de acordo com o Grupo 1 e 40\% de acordo com o Grupo 5, parcialmente por cisalhamento. 40\% das rupturas sofreram flambagem, mas somente $5 \%$ condizente com o Grupo 2 . Um quarto dos ensaios apresentaram deslizamentos na região de pinçamento. Mais especificamente: a camada externa apresentou $20 \%$ de falhas do Grupo 1; $60 \%$ do Grupo 4, parcialmente por cisalhamento; $20 \%$ consistentes com o Grupo 2 e $40 \%$ por flambagem parcial, além de $20 \%$ por deslizamento parcial na área de pinçamento. Na camada medial externa $100 \%$ das falhas são influenciadas por cisalhamento, das quais $60 \%$ consistentes com o Grupo 1; $40 \%$ apresentam influência associada de flambagem e deslizamentos na região de pinçamento. $\mathrm{Na}$ camada medial interna apresenta-se quadro similar, em que $100 \%$ das rupturas sofrem a influência do cisalhamento, mas somente $40 \%$ se enquadram no Grupo; Ocorreram deslizamentos em $40 \%$ dos casos e flambagem em $20 \%$. $\mathrm{Na}$ camada interna $80 \%$ das falhas ocorrem por cisalhamento, das quais $60 \%$ classificáveis como Grupo 1;deslizamentos na região da garra ocorreram em $40 \%$ dos ensaios e em $20 \%$ dos casos a ruptura foi parcialmente ocasionada por flambagem. 
6.

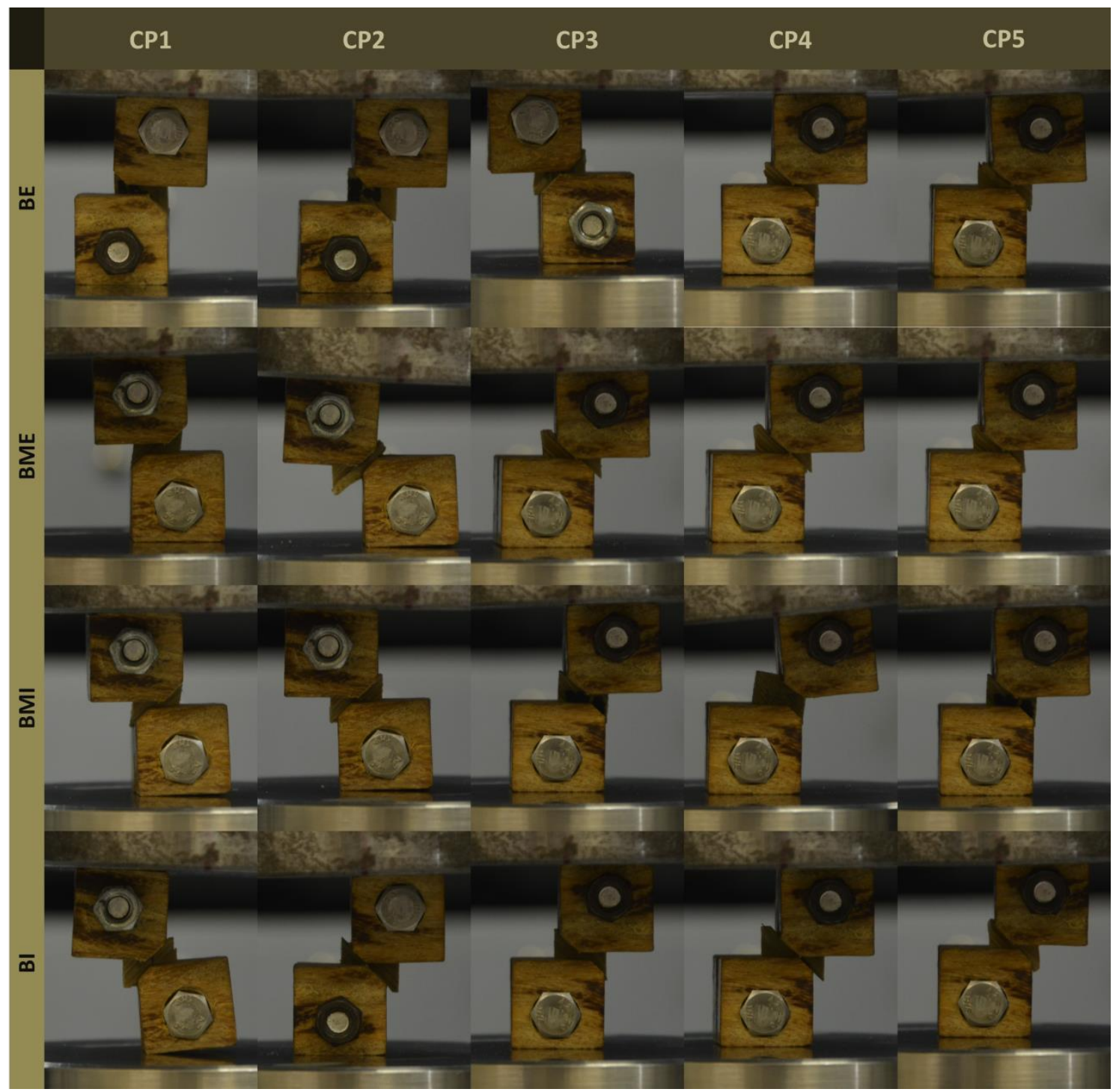

Figura 92: Modos de falha dos corpos-de-prova de cisalhamento. Cada bloco numerado (CP) provem de uma mesma régua da região basal, dividida em sua espessura.

Na porção central do colmo (Figura 93) 40\% das falhas ocorrem de acordo com o Grupo 1 e mais $40 \%$ rompem parcialmente por cisalhamento. $40 \%$ dos ensaios apresentam ruptura parcial por flambagem e em $40 \%$ dos casos ocorreu deslizamento na área de pinçamento. Analisando por camada, observa-se que na parte externa, embora $80 \%$ das falhas sofrerem a influência do esforço de cisalhamento, somente $40 \%$ enquadram-se como Grupo 1; $40 \%$ dos ensaios romperam parcialmente por flambagem e deslizamentos ocorreram em $20 \%$ dos ensaios. Na camada medial $80 \%$ das falhas tem a influência do esforço de cisalhamento e 60\% classificam-se como Grupo 1.Houve deslizamentos em 40\% dos ensaios e uma das rupturas ocorreu parcialmente por flambagem. $\mathrm{Na}$ camada interna $80 \%$ das rupturas tiveram a participação do esforço de 
6.

cisalhamento, embora somente $20 \%$ sejam classificáveis como Grupo 1; $60 \%$ das falhas ocorreram parcialmente por flambagem e ocorreram deslizamentos em $40 \%$ dos ensaios.

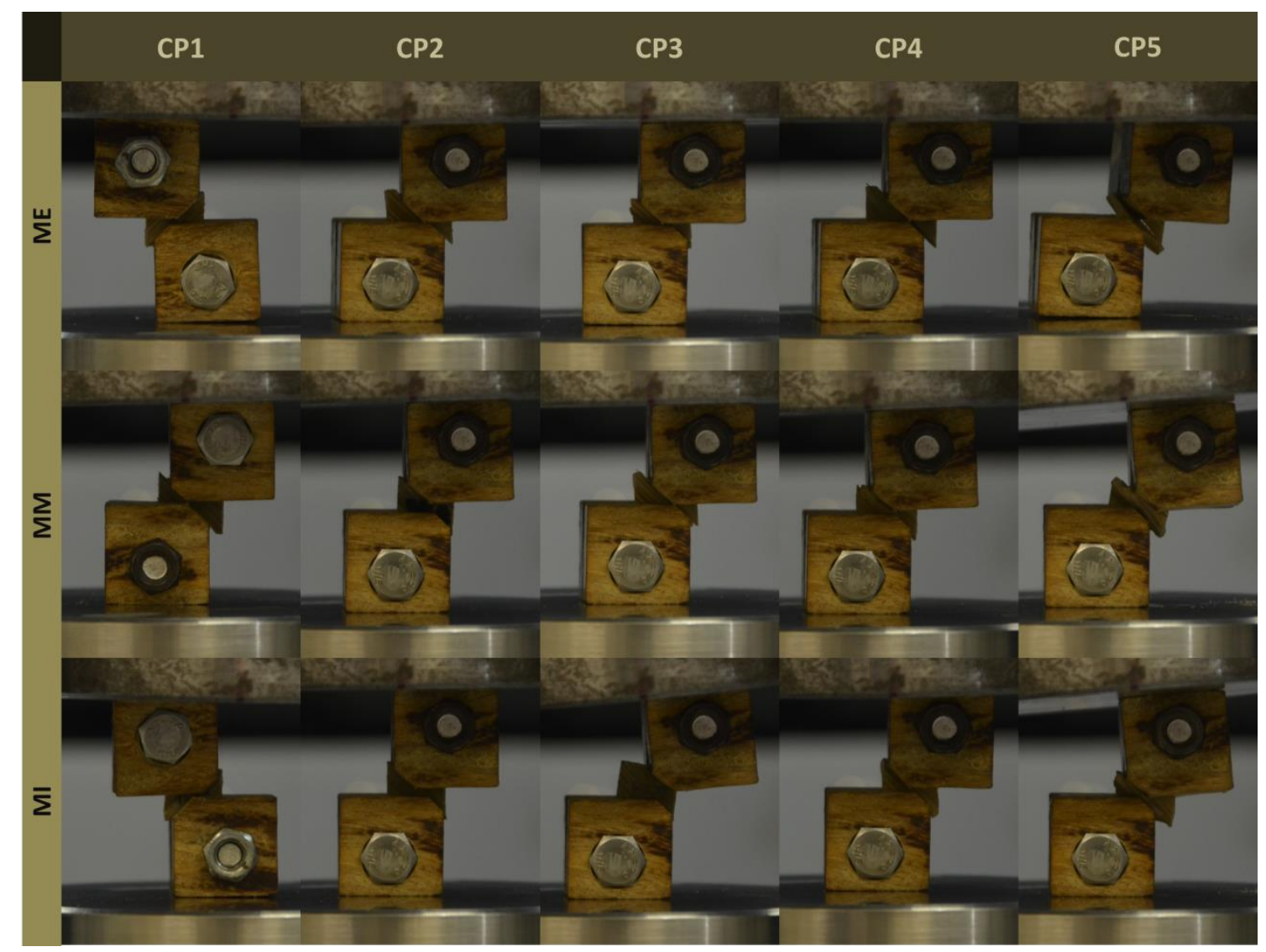

Figura 93: Modos de falha dos corpos-de-prova de cisalhamento. Cada bloco numerado (CP) provem de uma mesma régua da região central, dividida em sua espessura.

$\mathrm{Na}$ região apical (Figura 94) 60\% das falhas são caracterizadas como Grupo 1 e mais 20\% ocorrem parcialmente por cisalhamento; e 30\% dos ensaios ocorreu deslizamento na área da garra e somente $10 \%$ apresentou ruptura parcial por flambagem.

A camada externa teve $60 \%$ das falhas pertinentes ao Grupo 1 e mais $20 \%$ parcialmente por cisallhamento; em $20 \%$ dos ensaios a ruptura caracterizou-se unicamente pelo deslizamento, e mais $20 \%$ em que ocorreu deslizamento associado a cisalhamento. Na camada interna $60 \%$ das falhas foram condizentes com o Grupo 1, 20\% com o Grupo 3 e 20\% apresentaram falha mista entre flambagem e cisalhamento. 
6.

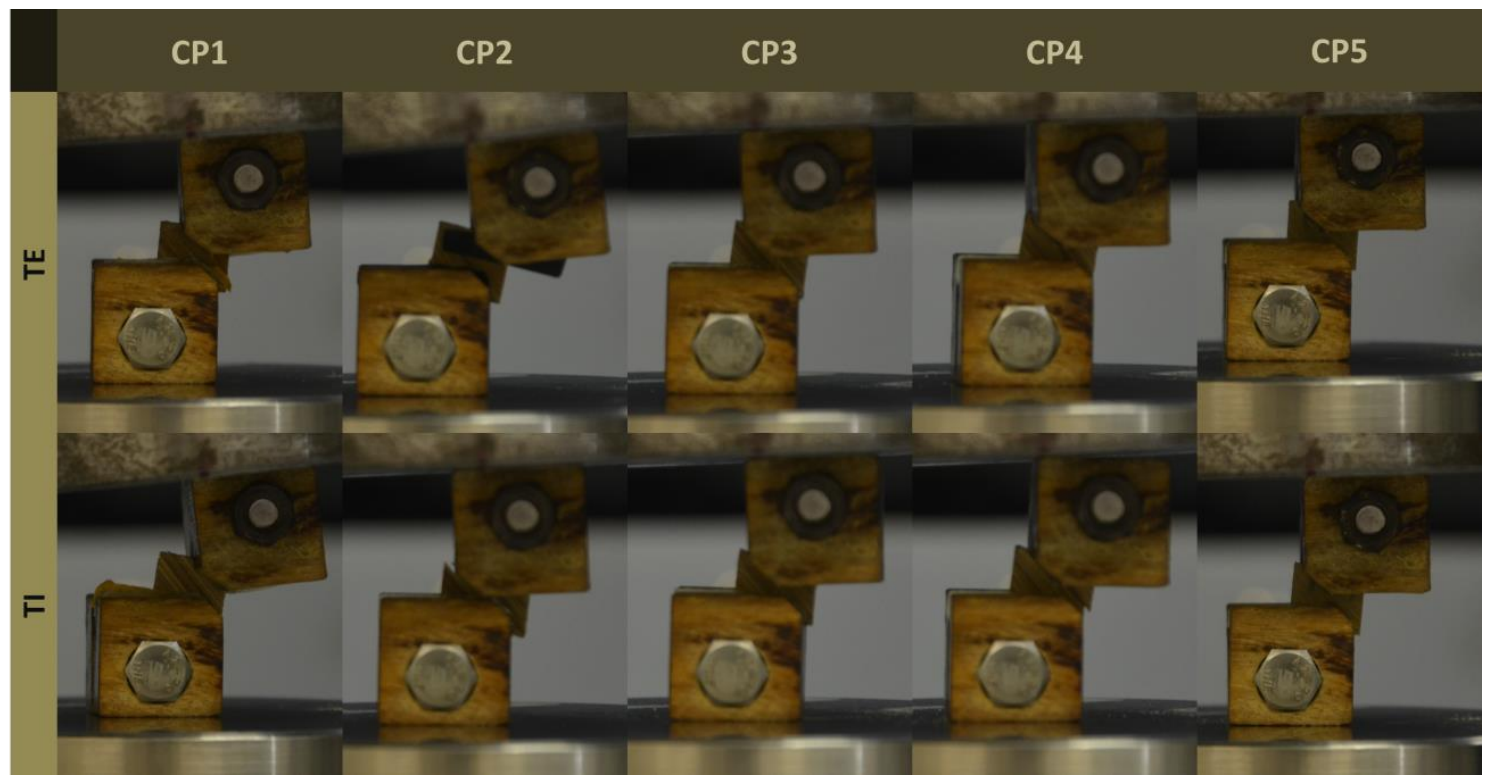

Figura 94: Modos de falha dos corpos-de-prova de cisalhamento. Cada bloco numerado (CP) provem de uma mesma régua da região apical, dividida em sua espessura.

A Figura 95, a Figura 96 e a Figura 97 comparam respectivamente frações volumétricas de fibras, matriz e vazios com propriedades mecânicas obtidas nos ensaios ao cisalhamento.
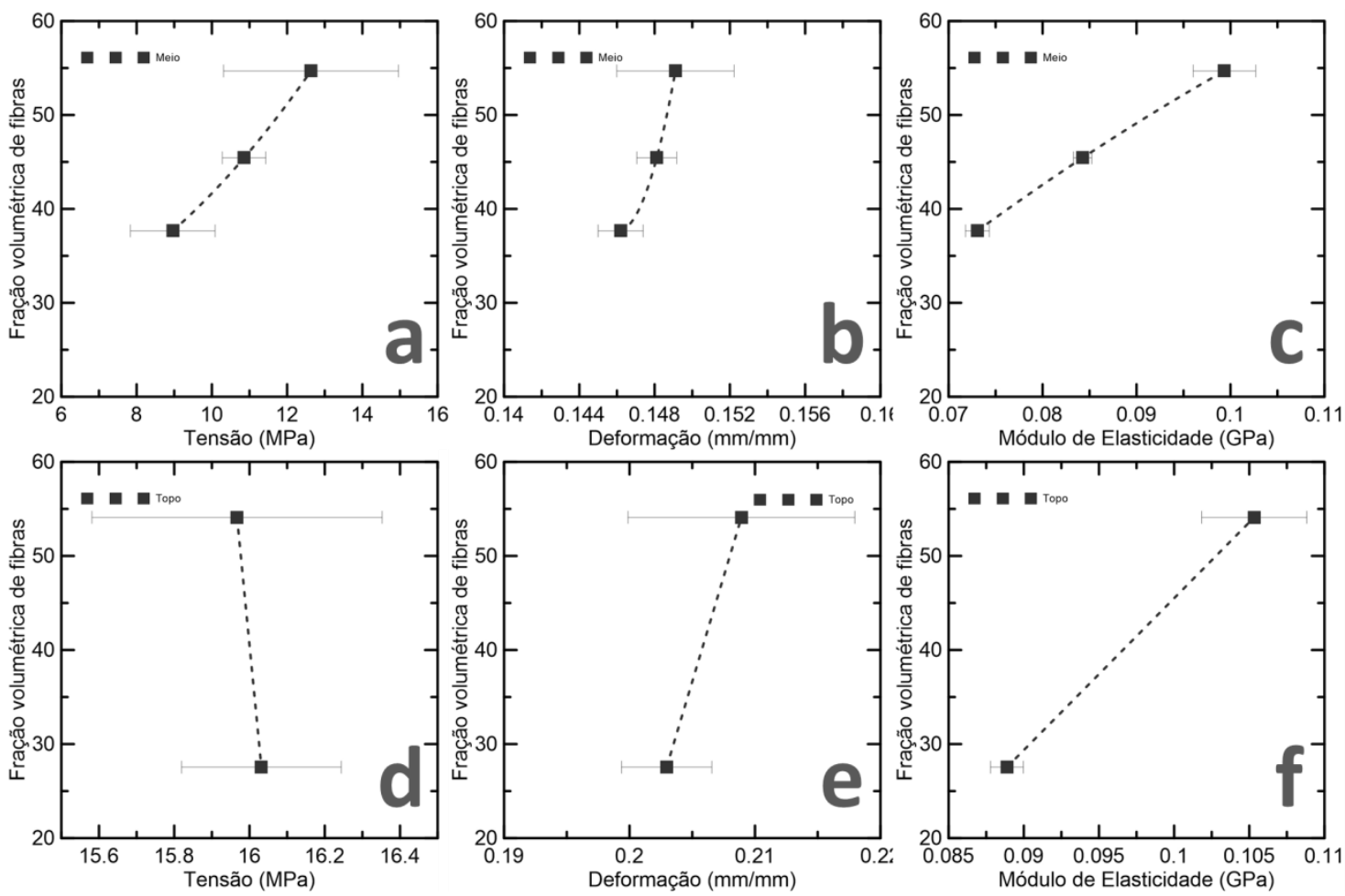

Figura 95: Relação entre a fração volumétrica de fibras e: a) tensão na região central; b) deformação na região central; c) módulo de elasticidade na região central; d) tensão na região apical; e) deformação na região apical e f) módulo de elasticidade na região apical. 
6.

Analisando a relação entre a fração volumétrica de fibras e a resistência ao cisalhamento na porção central do colmo percebe-se uma proporcionalidade quase linear. O mesmo ocorre para a rigidez. Para a região apical a lógica não se aplica à resistência, que parece crescer em proporção inversa à concentração de fibras.
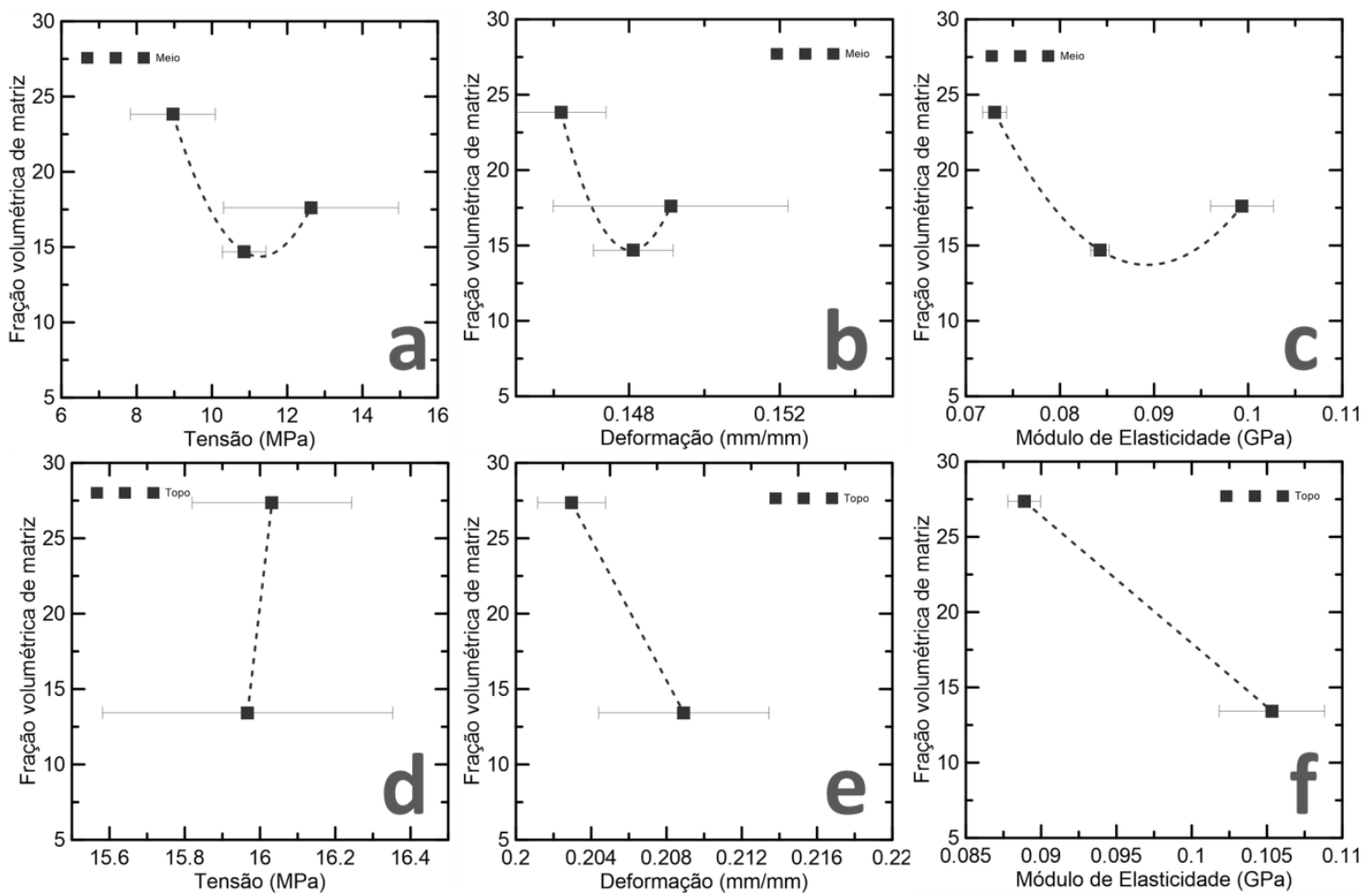

Figura 96: Relação entre a fração volumétrica de matriz e: a) tensão na região central; b) deformação na região central; c) módulo de elasticidade na região central; d) tensão na região apical; e) deformação na região apical e f) módulo de elasticidade na região apical.

Observa-se, para a região central, que a fração de matriz não parece ter influência na resistência ou na rigidez, uma vez que apresenta uma relação não linear em que a menor fração não corresponde à melhor propriedade. No caso da região apical, a falta de mais pontos prejudica uma análise mais apurada, indicando apenas linhas de tendência, que mais uma vez não seguem a lógica de menor matriz melhor propriedade. 
6.
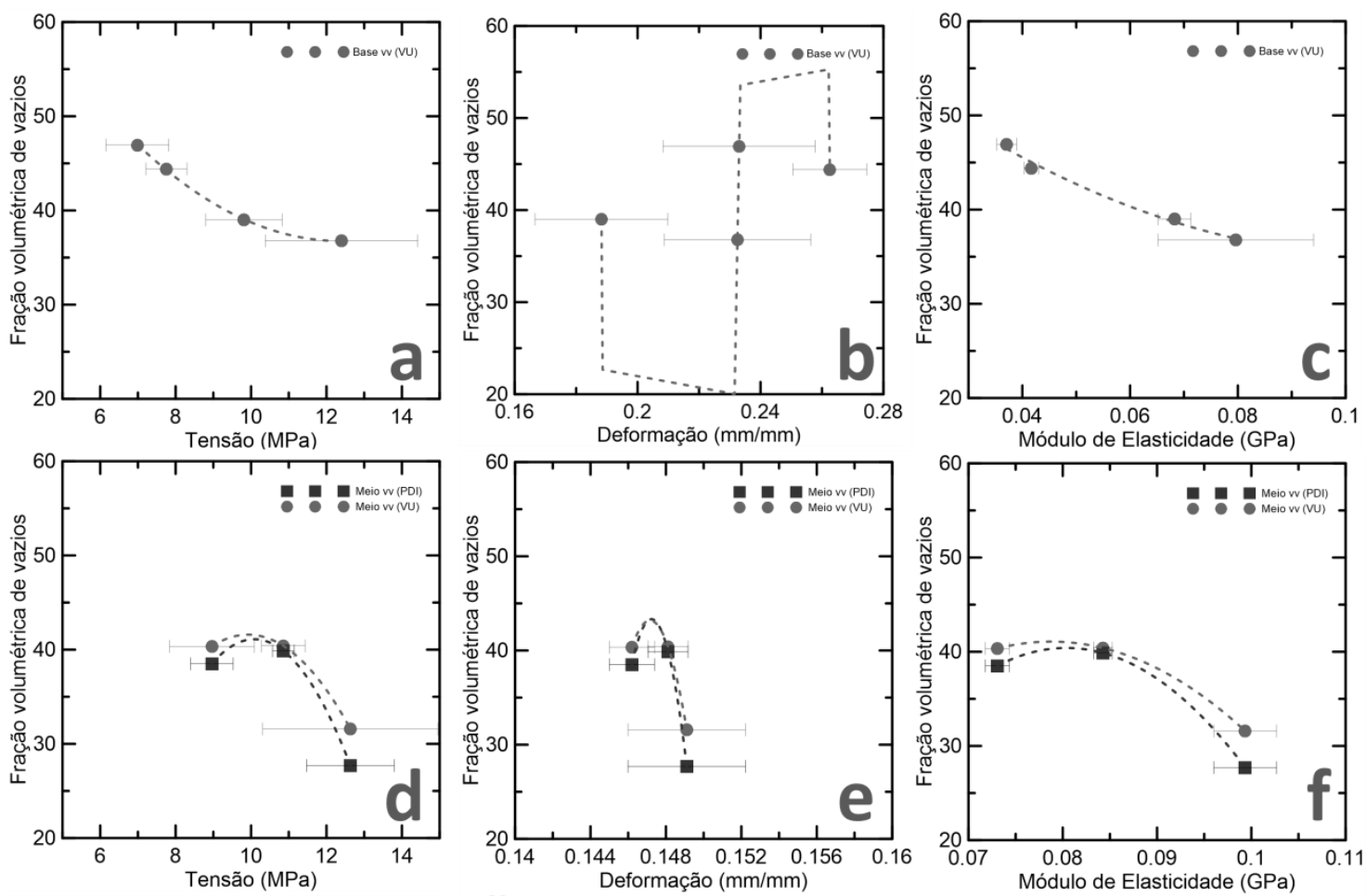

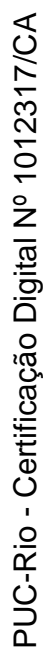
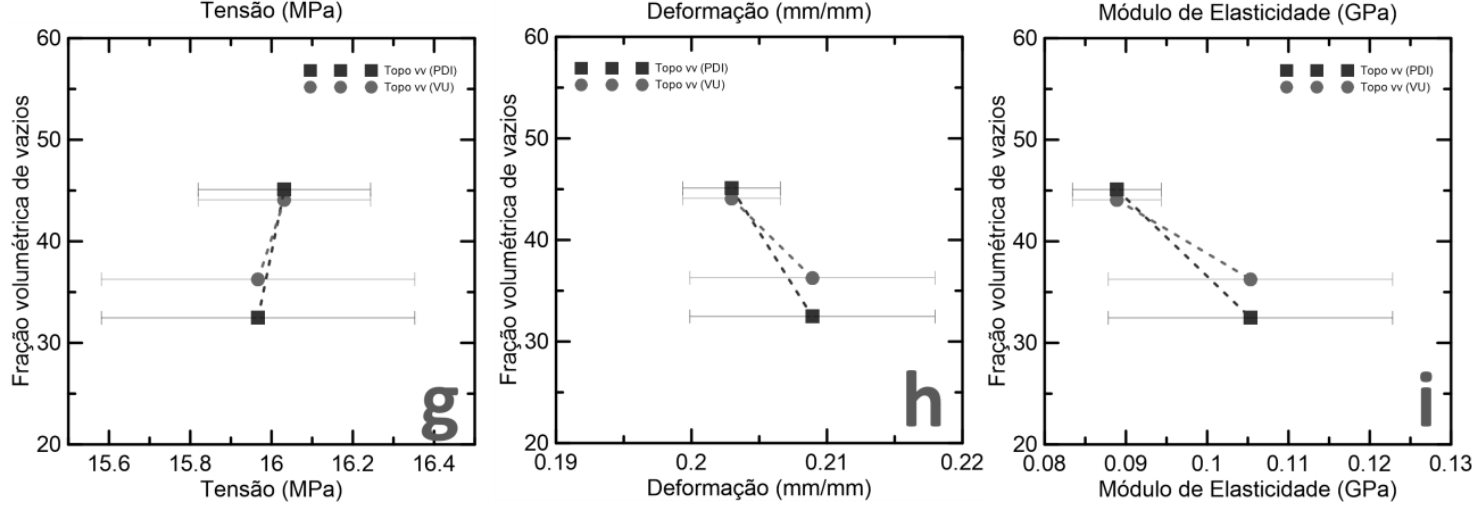

Figura 97: Relação entre a fração volumétrica de vazios obtida por PDI e pelo método proposto e: a) tensão na região basal; b) deformação na região basal; c) módulo de elasticidade na região basal; d) tensão na região medial; e) deformação na região medial; f) módulo de elasticidade na região medial; g) tensão na região apical; h) deformação na região apical e i) módulo de elasticidade na região apical.

Menores frações volumétricas de vazios parecem se correlacionar com módulos de elasticidade mais altos, mas a relação com a resistência, a exemplo da análise realizada para as demais frações volumétricas de constituintes não segue a lógica preconcebida. 
6.

\subsubsection{Ensaios de flexão 3 pontos}

A Tabela 24 apresenta a lista dos corpos-de-prova, seus modos de ruptura e algumas das propriedades físicas e mecânicas e a Figura 90 as curvas carga $x$ deslocamento de todos os ensaios, divididas por blocos de corpos-de-prova.

Tabela 24: Quadro com os corpos-de-prova, algumas de suas propriedades físicas e mecânicas e uma descrição dos seus modos de ruptura.

\begin{tabular}{|c|c|c|c|c|c|c|c|}
\hline corpos-de-prova & $\begin{array}{c}\text { volume } \\
\text { (cm3) }\end{array}$ & $\begin{array}{c}\text { massa } \\
\text { (g) }\end{array}$ & $\begin{array}{c}\text { densidade } \\
\text { (g/cm3) }\end{array}$ & modo de falha & $F_{\text {máx }}$ & $\mathbf{V}_{\text {máx }}$ & $\mathbf{E}$ \\
\hline BE1 & 8,79 & 9,13 & 1,04 & tração (tra) & 0,09 & 24,22 & 19,21 \\
\hline BME1 & 9,27 & 7,56 & 0,82 & tra & 0,07 & 19,91 & 15,40 \\
\hline BMI1 & 9,23 & 6,14 & 0,67 & falha equilbrada (eq) & 0,06 & 37,88 & 15,69 \\
\hline BI1 & 9,96 & 6,71 & 0,67 & compressão (comp) & 0,05 & 14,53 & 13,31 \\
\hline BE2 & 8,67 & 8,99 & 1,04 & tra & 0,08 & 22,44 & 19,08 \\
\hline BME2 & 9,27 & 7,39 & 0,80 & eq & 0,06 & 17,06 & 14,80 \\
\hline BMI2 & 9,09 & 6,46 & 0,71 & eq & 0,05 & 18,67 & 12,83 \\
\hline $\mathrm{B} 12$ & 9,25 & 6,15 & 0,66 & comp & 0,05 & 17,47 & 12,92 \\
\hline BE3 & 8,63 & 8,89 & 1,03 & tra & 0,08 & 23,67 & 18,69 \\
\hline BME3 & 9,13 & 7,38 & 0,81 & eq & 0,06 & 19,80 & 14,30 \\
\hline BMI3 & 9,38 & 6,95 & 0,74 & eq & 0,06 & 17,85 & 14,73 \\
\hline $\mathrm{B} 13$ & 9,23 & 6,85 & 0,74 & comp & 0,06 & 19,43 & 12,68 \\
\hline BE4 & 8,92 & 9,34 & 1,05 & tra & 0,09 & 23,68 & 18,16 \\
\hline BME4 & 8,94 & 6,92 & 0,77 & eq & 0,06 & 18,21 & 17,60 \\
\hline BMI4 & 9,34 & 6,67 & 0,71 & eq & 0,05 & 16,94 & 14,03 \\
\hline $\mathrm{B} 14$ & 9,20 & 6,54 & 0,71 & eq & 0,06 & 17,58 & 14,78 \\
\hline BE5 & 8,82 & 8,59 & 0,97 & eq & 0,08 & 22,39 & 19,06 \\
\hline BME5 & 8,71 & 6,55 & 0,75 & eq & 0,06 & 20,52 & 13,83 \\
\hline BMI5 & 8,82 & 6,30 & 0,71 & eq & 0,05 & 17,90 & 14,23 \\
\hline BI5 & 9,34 & 6,56 & 0,70 & eq & 0,06 & 15,68 & 17,24 \\
\hline ME1 & 8,36 & 8,57 & 1,02 & tra & 0,08 & 33,05 & 13,80 \\
\hline MM1 & 7,59 & 5,82 & 0,77 & não rompeu (nr) & 0,04 & 34,58 & 9,08 \\
\hline MI1 & 8,82 & 6,78 & 0,77 & eq & 0,06 & 25,21 & 11,37 \\
\hline ME2 & 8,61 & 8,01 & 0,93 & tra & 0,07 & 28,67 & 13,36 \\
\hline MM2 & 8,00 & 5,99 & 0,75 & tra & 0,04 & 29,78 & 9,86 \\
\hline MI2 & 8,65 & 6,76 & 0,78 & eq & 0,05 & 27,57 & 10,65 \\
\hline ME3 & 8,32 & 8,90 & 1,07 & tra & 0,08 & 27,81 & 16,92 \\
\hline MM3 & 7,94 & 6,68 & 0,84 & tra & 0,05 & 20,52 & 15,34 \\
\hline MI3 & 8,16 & 6,43 & 0,79 & eq & 0,05 & 31,05 & 9,55 \\
\hline ME4 & 8,24 & 8,27 & 1,00 & tra & 0,07 & 31,75 & 14,37 \\
\hline MM4 & 8,20 & 6,78 & 0,83 & tra & 0,05 & 29,23 & 11,75 \\
\hline MI4 & 8,20 & 6,06 & 0,74 & tra & 0,05 & 32,57 & 9,37 \\
\hline ME5 & 8,20 & 7,85 & 0,96 & tra & 0,07 & 27,34 & 16,63 \\
\hline MM5 & 8,41 & 7,27 & 0,87 & eq & 0,07 & 24,30 & 16,39 \\
\hline MI5 & 8,20 & 6,37 & 0,78 & eq & 0,05 & 25,57 & 13,05 \\
\hline TE1 & 8,34 & 8,86 & 1,06 & tra & 0,07 & 31,10 & 12,52 \\
\hline TI1 & 8,12 & 7,32 & 0,90 & tra & 0,04 & 30,33 & 9,18 \\
\hline TE2 & 8,26 & 8,66 & 1,05 & tra + cisalhamento (cis) & 0,06 & 31,02 & 12,41 \\
\hline TI2 & 8,72 & 7,69 & 0,88 & $\mathrm{nr}$ & 0,03 & 39,96 & 4,46 \\
\hline TE3 & 8,53 & 8,37 & 0,98 & tra & 0,06 & 29,88 & 12,41 \\
\hline TI3 & 8,28 & 6,80 & 0,82 & tra & 0,05 & 28,08 & 9,95 \\
\hline TE4 & 8,36 & 8,72 & 1,04 & cis + tra & 0,07 & 32,78 & 13,09 \\
\hline T14 & 8,36 & 7,10 & 0,85 & cis + tra & 0,04 & 29,92 & 8,98 \\
\hline TE5 & 8,36 & 8,76 & 1,05 & tra & 0,07 & 31,95 & 13,89 \\
\hline TI5 & 8,36 & 6,91 & 0,83 & cis + tra & 0,05 & 30,58 & 9,18 \\
\hline
\end{tabular}


6.

corpo-de-prova 1

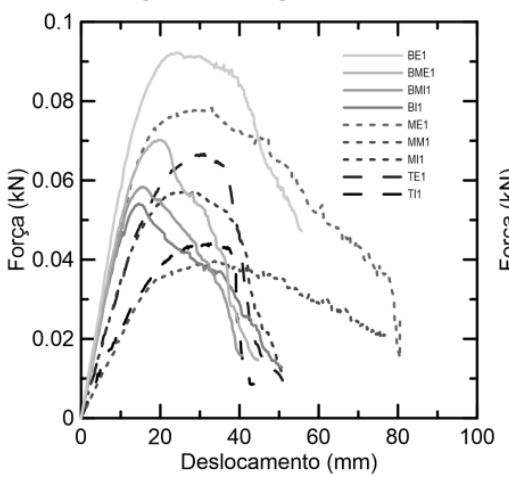

corpo-de-prova 2

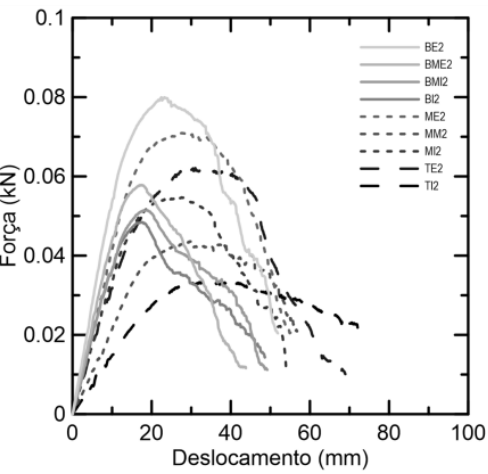

corpo-de-prova 3

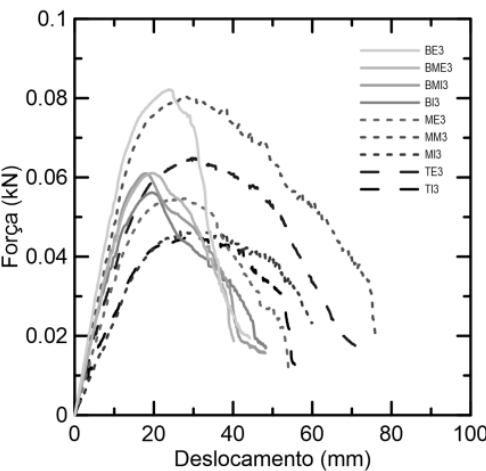

corpo-de-prova 4

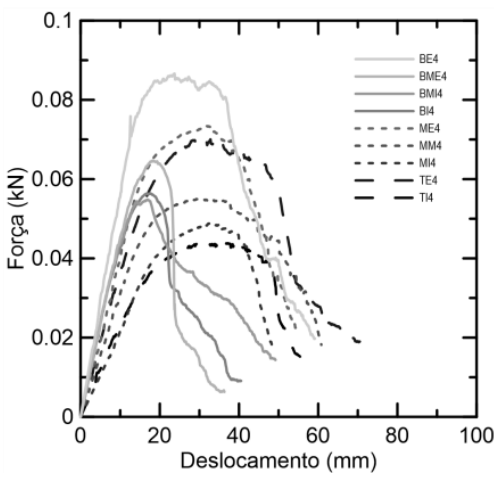

corpo-de-prova 5

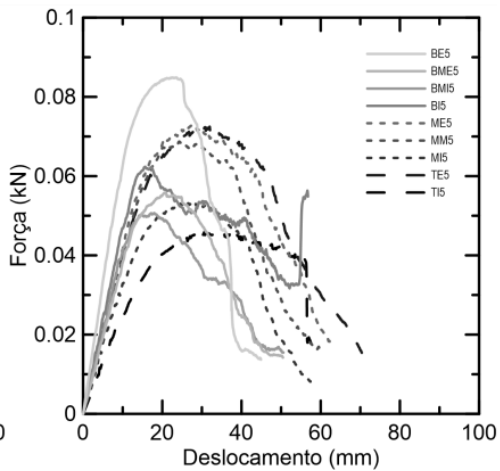

Figura 98: Curvas carga $x$ deslocamento das diferentes camadas e porções do colmo, separadas por blocos de corpos-de-prova.

A Tabela 25 apresenta um quadro resumo com as propriedades físicas e mecânicas e a Figura 99 curvas representativas do comportamento dos corposde-prova ensaiados à flexão.

Tabela 25: Sumário das propriedades físicas e mecânicas médias e seus respectivos desvios padrão, para as diferentes camadas e porções de colmo, bem como suas propriedades específicas.

\begin{tabular}{|l|r|r|r|r|r|r|r|r|r|r|}
\hline corpos-de-prova & $\boldsymbol{V}_{\text {med }}$ & $\boldsymbol{V}_{\text {std }}$ & $\mathbf{F}_{\text {med }}$ & $\mathbf{F}_{\text {std }}$ & $\mathbf{V}_{\text {med }}$ & $\mathbf{V}_{\text {std }}$ & $\mathbf{E}_{\text {med }}$ & $\mathbf{E}_{\text {std }}$ & $\mathbf{F} / \boldsymbol{V}$ & $\mathbf{E} / \boldsymbol{V}$ \\
\hline BE & 1,03 & 0,03 & 0,09 & 0,00 & 23,28 & 0,73 & 18,84 & 0,38 & 0,09 & 8,29 \\
\hline BME & 0,79 & 0,02 & 0,06 & 0,01 & 19,10 & 1,28 & 15,18 & 1,31 & 0,08 & 9,22 \\
\hline BMI & 0,71 & 0,02 & 0,06 & 0,00 & 21,85 & 8,04 & 14,30 & 0,93 & 0,08 & 20,14 \\
\hline BI & 0,70 & 0,03 & 0,06 & 0,00 & 16,94 & 1,69 & 14,19 & 1,69 & 0,09 & 20,27 \\
\hline ME & 1,00 & 0,05 & 0,08 & 0,00 & 29,73 & 2,26 & 15,01 & 1,48 & 0,08 & 15,01 \\
\hline MM & 0,81 & 0,04 & 0,05 & 0,01 & 27,68 & 4,84 & 12,49 & 2,91 & 0,06 & 15,42 \\
\hline MI & 0,77 & 0,02 & 0,05 & 0,00 & 28,40 & 2,94 & 10,80 & 1,34 & 0,06 & 14,03 \\
\hline TE & 1,04 & 0,03 & 0,07 & 0,00 & 31,34 & 0,97 & 12,86 & 0,57 & 0,07 & 12,37 \\
\hline TI & 0,86 & 0,03 & 0,04 & 0,00 & 31,77 & 4,19 & 8,35 & 1,97 & 0,05 & 9,71 \\
\hline
\end{tabular}


6.
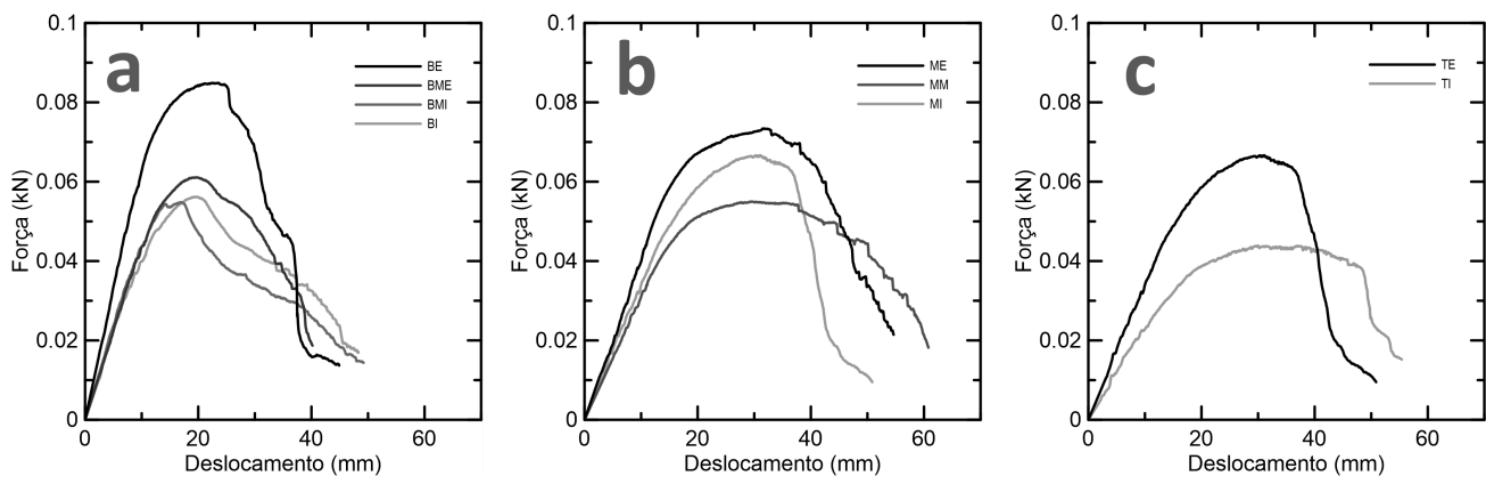

Figura 99: Gráficos carga x deslocamento de curvas representativas de corpos-deprova provenientes dos diferentes pontos das paredes das porções de colmo: a) basal; b) medial e c) apical.

Percebe-se pelas médias, que as propriedades mecânicas seguem a lógica prevista de incremento na direção radial, no sentido de dentro para fora da parede do colmo e, embora nas curvas características apresentadas o corpo-deprova central medial não apresente o comportamento descrito, uma análise mais aprofundada dos gráficos gerais permite verificar que, em geral, para amostras provenientes do mesmo trecho de colmo, a variação se mantém conforme.

Nota-se ainda que, em desacordo com o pressuposto, as propriedades decrescem em qualidade da porção basal para a apical.

Os modos de ruptura observados podem ser classificados em grupos principais (Figura 100):

Grupo 1: falha na seção comprimida;

Grupo 2: falha na seção tracionada;

Grupo 3: falha equilibrada, isto é, ruptura concomitante nas seções comprimida e tracionada;

Grupo 4: falha por cisalhamento interlaminar associado à tração e

Grupo 5: não ruptura. 
6.
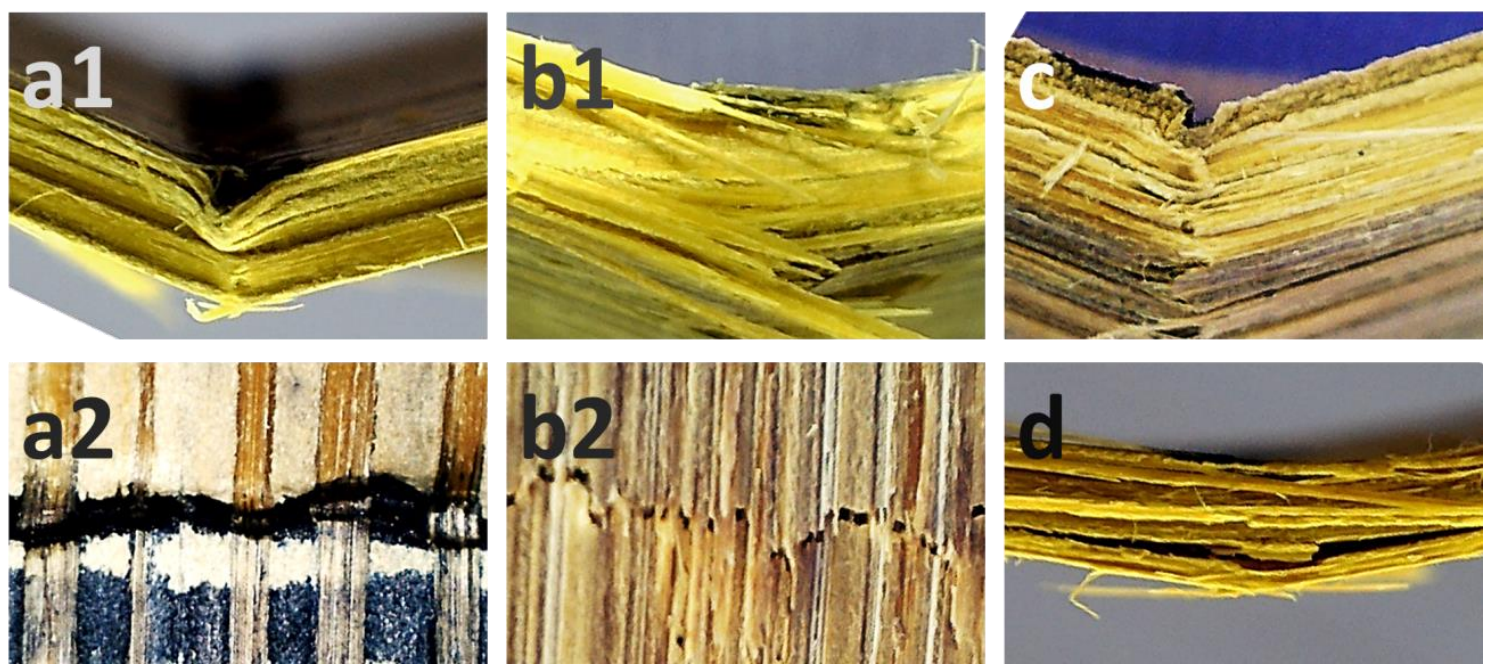

Figura 100: Modos de ruptura característicos dos ensaios a flexão 3 pontos das lâminas provenientes dos diferentes pontos das paredes das porções de colmo. a1) ruptura dominada pela seção comprimida - vista lateral; a2) vista superior; b1) falha dominada pela seção tracionada - vista lateral; b2) vista inferior; c) falha equilibrada entre as seções tracionada e comprimida; d) falha por cisalhamento interlaminar associado à tração.

Analisando os modos de falha relatados na Tabela 24 e detalhados por Grupo na Figura 100 verifica-se que, 6,7\% dos ensaios romperam de acordo com o Grupo 1, 28,9\% dos corpos-de-prova apresentam falha consistente com o Grupo 2, 30\% da forma descrita para o Grupo 3, 8,9\% conforme o Grupo 4 e 4,4\% segundo o Grupo 5.

Numa análise mais pormenorizada, na porção basal, $80 \%$ das falhas das lâminas externas ocorreram na seção tracionada em consonância com o Grupo 2 e $20 \%$ de maneira equilibrada (Grupo 3); na camada medial externa as falhas são dominadas pelo Grupo $3(80 \%)$ e $20 \%$ dos ensaios rompem por tração; o Grupo 3 rege ainda 100\% das rupturas da camada medial interna, bem como $40 \%$ das da camada interna; os $60 \%$ restantes são dominados pela falha à compressão que caracteriza o Grupo 1.

Na porção central $100 \%$ das rupturas da camada externa são dominadas pelo Grupo 2, bem como $60 \%$ das falhas registradas na camada medial; entre as demais rupturas, $20 \%$ são regidas pelo Grupo 3 e outros 20\% não romperam (Grupo 5); na camada interna 20\% das rupturas ocorrem de acordo com o Grupo 2 e as demais (80\%) segundo o Grupo 3.

$\mathrm{Na}$ porção apical do colmo as falhas na camada externa são dominadas pela região tracionada, sendo 60\% referentes ao Grupo 2 e $40 \%$ associadas a cisalhamento, caracterizando Rupturas pelo Grupo 4; a camada interna, de 
6.

forma similar tem $40 \%$ das rupturas consistentes com Grupo 2, 40\% com o Grupo 4 e 20\% não romperam (Grupo 5).

A Figura 101, a Figura 102 e a Figura 103 comparam respectivamente frações volumétricas de fibras, matriz e vazios com propriedades mecânicas obtidas nos ensaios à flexão.
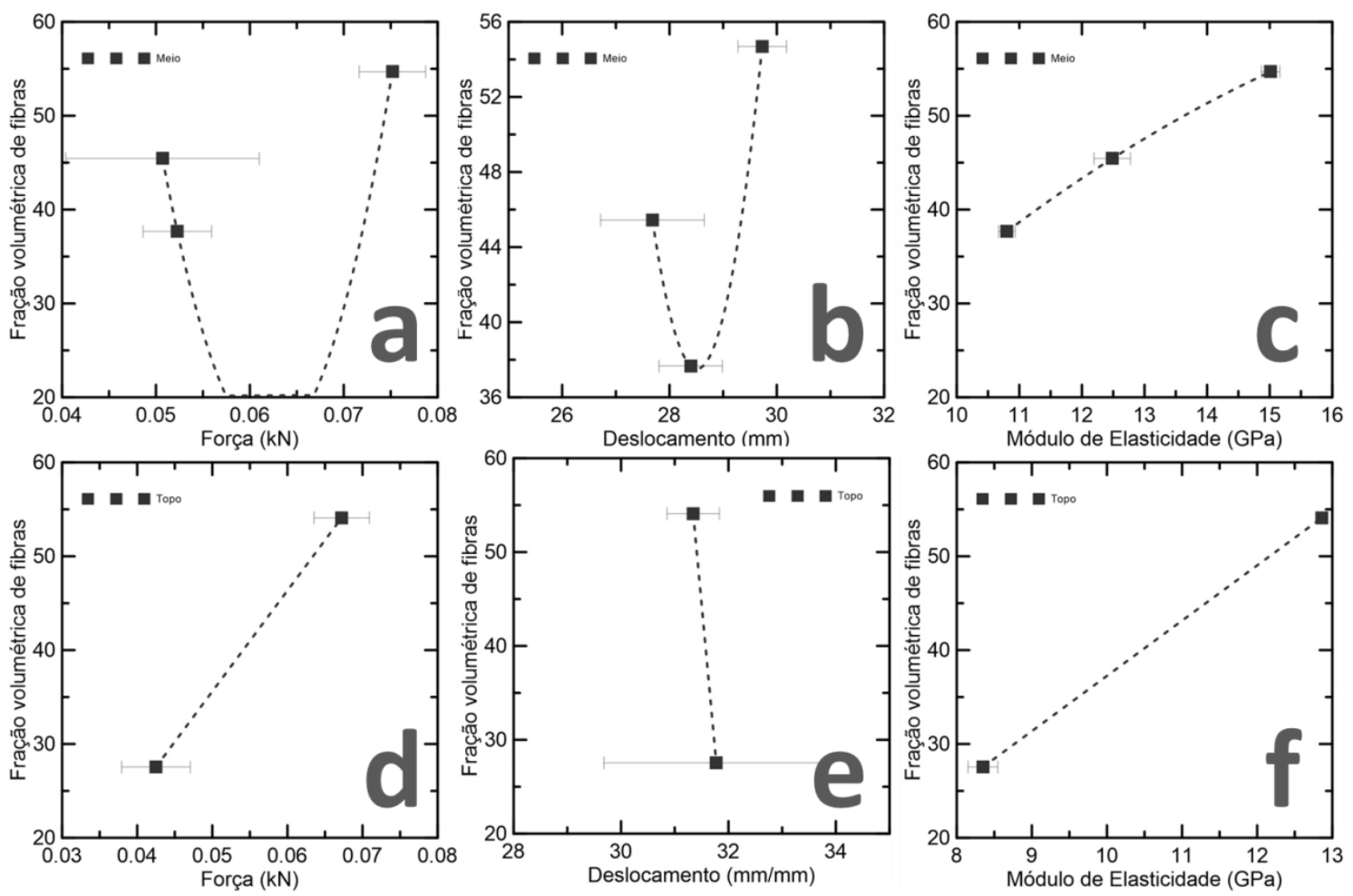

Figura 101: Relação entre a fração volumétrica de fibras e: a) força máxima na região central; b) flecha na região central; c) módulo de elasticidade na região central; d) força máxima na região apical; e) deslocamento na região apical e f) módulo de elasticidade na região apical.

A expressiva não linearidade na comparação da variação da fração volmétrica de fibras com a resistência mecânica na porção central do colmo indica que este não é um fator determinante. Entretanto, percebe-se que há dois pontos muito próximos em termos de resistência e com uma diferença inferior a $10 \%$ na fração volumétrica de fibras. Em contrapartida o módulo de elasticidade parece sofrer influência direta e quase linear do teor de reforço. 
6.
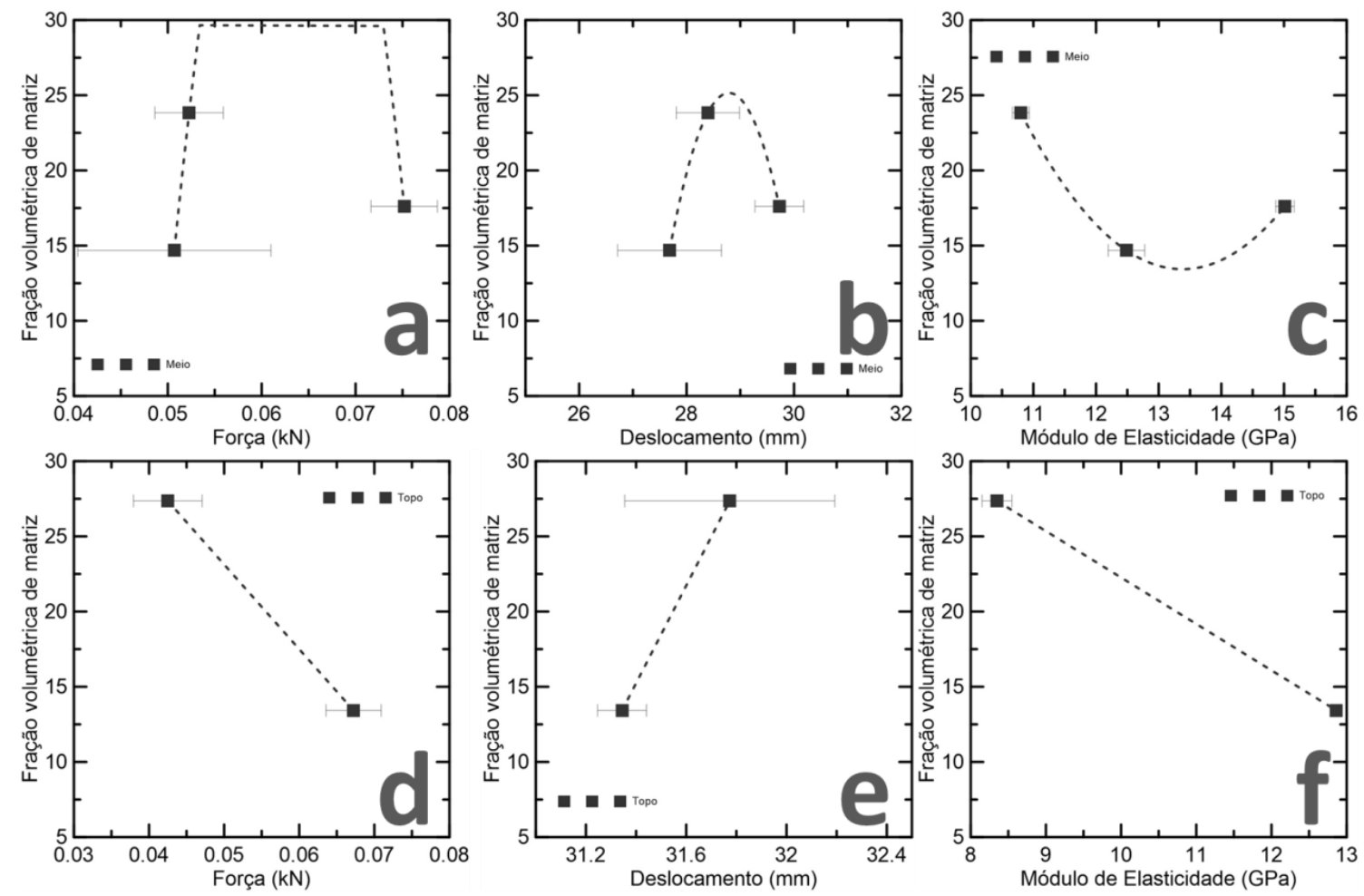

Figura 102: Relação entre a fração volumétrica de matriz e: a) força máxima na região central; b) flecha na região central; c) módulo de elasticidade na região central; d) força máxima na região apical; e) flecha na região apical e f) módulo de elasticidade na região apical.

A variação na proporção de matriz é inversamente proporcional à proporção de fibras, de modo que a influência desta na resistência mecânica à flexão mecânicas, igualmente não é facilmente determinada.

Analisando conjuntamente as variações de proporção dos continentes e vazios, nota-se a influência do teor de vazios, que diferentemente dos materiais constituintes do compósito não apresenta na comparação com o esforço aplicado nenhuma não linearidade que contrarie o pressuposto de correlação de que a resistência mecânica aumenta conforme se reduzem os vazios, o que torna esta uma característica determinante para as propriedades mecânicas. 
6.
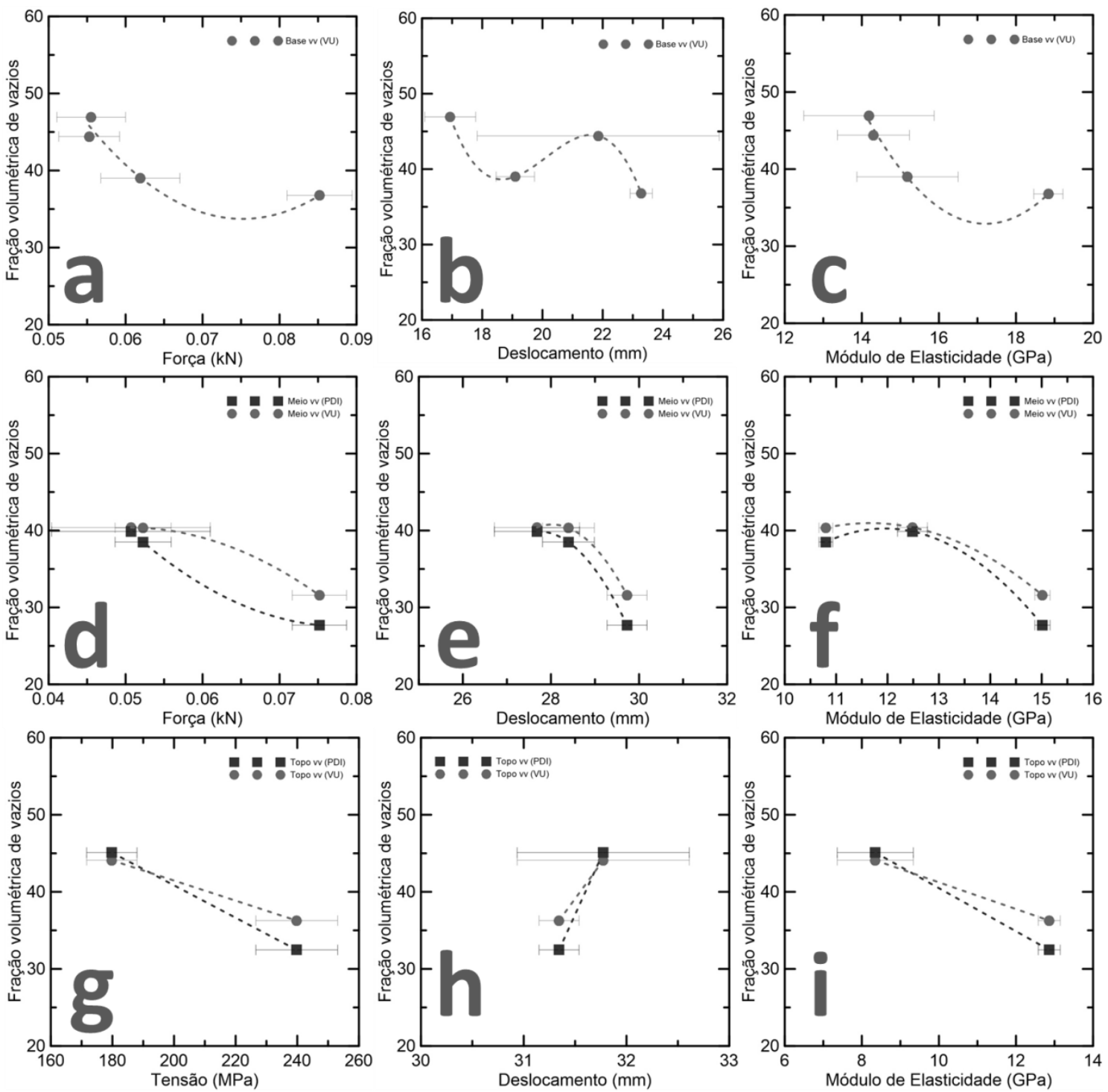

Figura 103: Relação entre a fração volumétrica de vazios obtida por PDI e pelo método proposto e: a) força máxima na região basal; b) flecha na região basal; c) módulo de elasticidade na região basal; d) força máxima na região medial; e) flecha na região medial; f) módulo de elasticidade na região medial; g) força máxima na região apical; h) flecha na região apical e i) módulo de elasticidade na região apical.

Em uma análise global, associando os modos de falha à especificação das frações volumétricas dos constituintes e vazios, pode-se inferir que as lâminas com maior fração volumétrica de fibras e menor de vazios rompem influenciadas predominantemente pela seção tracionada, enquanto, que os com menores frações de fibras e maiores de vazios tendem à ruptura influenciada pela seção comprimida, muito embora, na maior parte dos casos recaiam em uma falha equilibrada. Falhas por cisalhamento são minoritárias, dado que a espessura da lâminas é muito pequena. 
6.

\subsubsection{Ensaios de cisalhamento do adesivo}

A Tabela 26 e a Figura 104 apresentam respectivamente os resultados dos ensaios de cisalhamento na linha da colagem e os gráficos tensão x deformação dos mesmos.

Tabela 26: Resultados dos ensaios de cisalhamento na linha da colagem, incluindo as médias e desvios padrão.

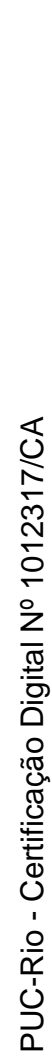

\begin{tabular}{|l|r|r|r|}
\multicolumn{1}{c|}{ corpos-de-prova } & $\sigma_{\text {máx }}$ & $\varepsilon_{\text {máx }}$ & Eg \\
\hline PU1 & 8,30 & 0,008 & 0,94 \\
\hline PU2 & 8,70 & 0,008 & 0,83 \\
\hline PU3 & 9,26 & 0,009 & 0,77 \\
\hline PU4 & 8,89 & 0,009 & 0,83 \\
\hline PU5 & 6,54 & 0,006 & 0,85 \\
\hline Médias & 8,34 & 0,01 & 0,84 \\
\hline Std. & 0,951 & 0,001 & 0,056 \\
\hline
\end{tabular}

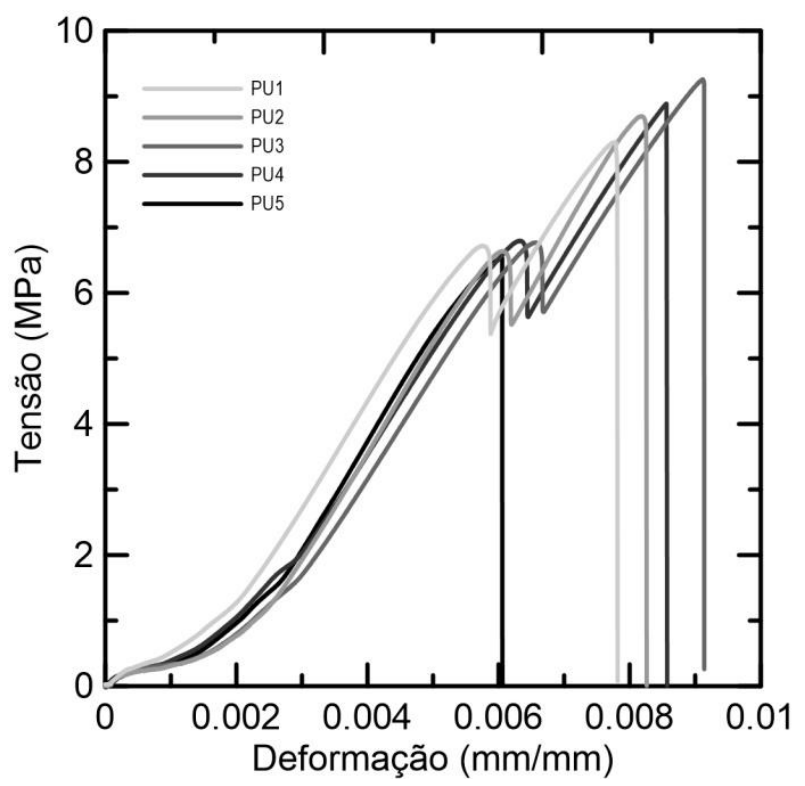

Figura 104: curvas tensão $\mathrm{x}$ deformação dos ensaios de cisalhamento do adesivo poliuretano utilizado para os laminados.

Verifica-se que a tensão média de ruptura é inferior à tensão média de ruptura a cisalhamento do bambu, de modo que espera-se que a ruptura ocorra nas linhas de colagem ou na interface entre o adesivo e o bambu. Assim sendo, 
6.

analisa-se as superfícies de falha exibida na Figura 105 para definir o modo de falha predominante ou os modos típicos.

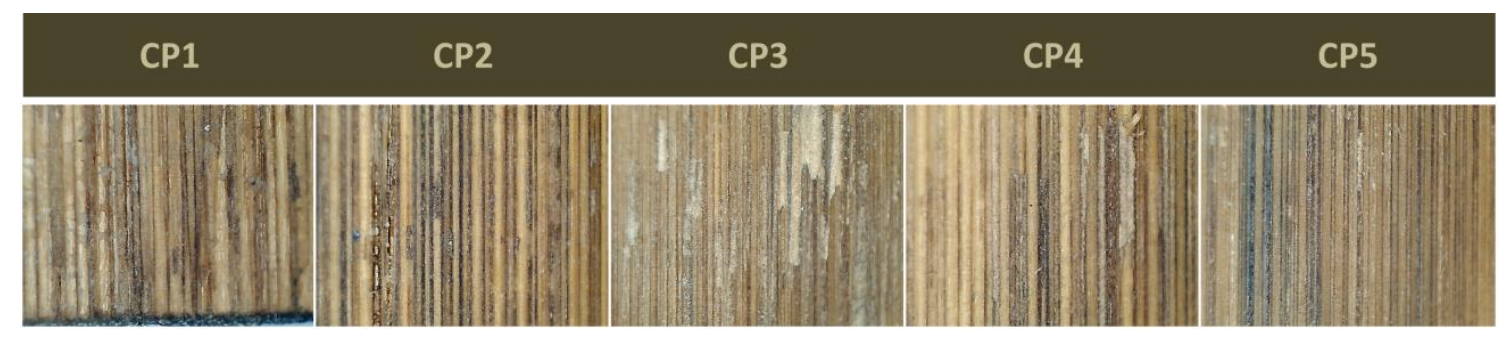

Figura 105: regiões de falha dos corpos-de-prova.

Pela análise das superfícies de ruptura verifica-se que a maior parte das falhas ocorrem na interação entre o adesivo e o material, que pode ser associada à ruptura parcial do adesivo, conforme evidenciam as imagens relativas aos corpos-de-prova 3 e 4. 


\section{7.}

\section{Ensaios mecânicos de laminados}

\subsection{Ensaios de flexão 3 pontos de laminados unidirecionais (variação de composição)}

O modelo de corpo-de-prova elaborado para os ensaios de flexão 3 pontos consiste de um laminado unidirecional com 5 camadas com seção de $20 \mathrm{~mm} \mathrm{x}$ $10 \mathrm{~mm}$ e comprimento de $200 \mathrm{~mm}$ (Figura 106).

Os corpos-de-prova foram obtidos a partir dos internós 13 e 14 (centrais) do colmo de Dendrocalamus giganteus proveniente da colheita de 2013, conforme detalhado na Tabela 3. A metodologia de confecção das lâminas está descrita detalhadamente na Seção 3.1.2. Após o procedimento descrito efetuase o corte transversal das lâminas com a medida desejada, no caso 200 mm.

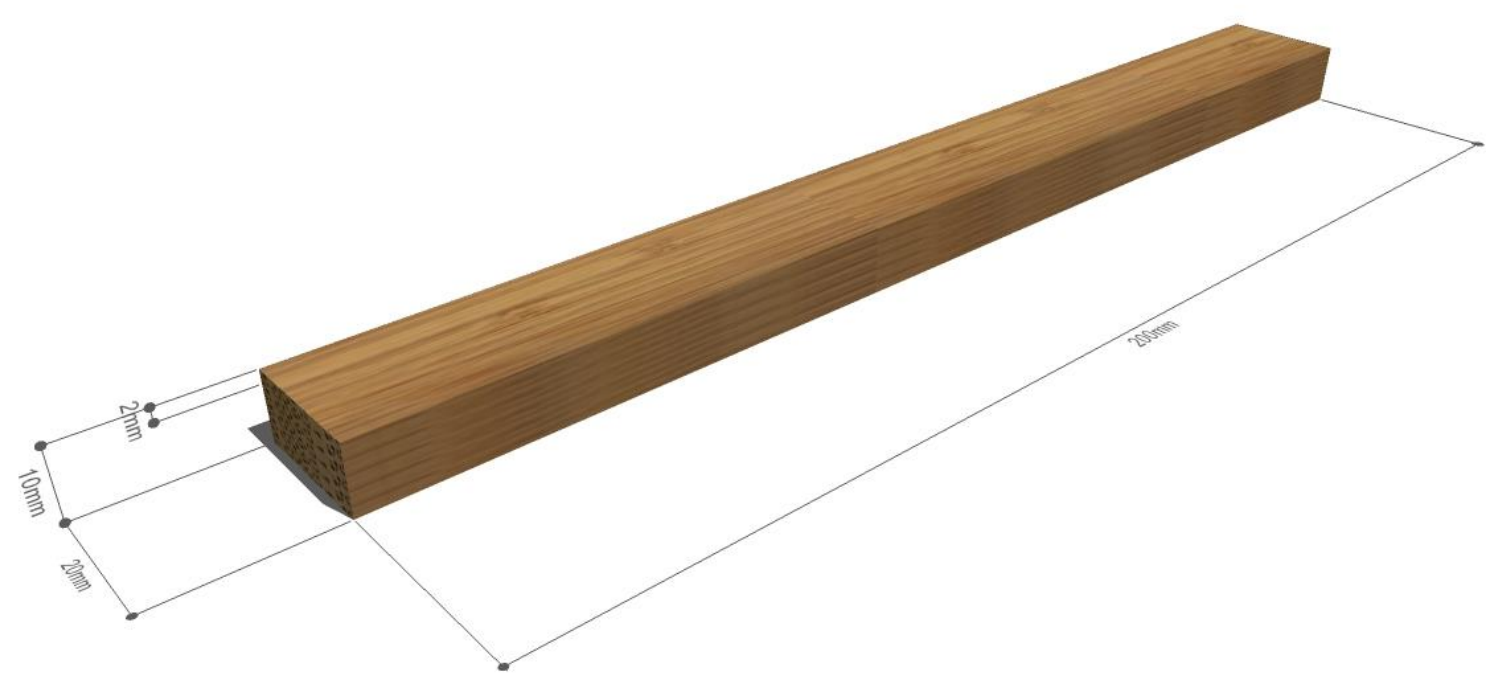

Figura 106: Corpo-de-prova de flexão, elaborado com composições de seções circunferenciais de diferentes pontos da parede do colmo.

Os ensaios de flexão são conduzidos utilizando um setup e procedimentos descritos para o ensaio à flexão 3 pontos em lâminas (Seção 1306.6) Foram ensaiados 5 corpos-de-prova para cada variável: leve, médio, resistente e 
7.

balanceado, totalizando um total de 20 ensaios. A Figura 107 apresenta o esquema de ensaio.

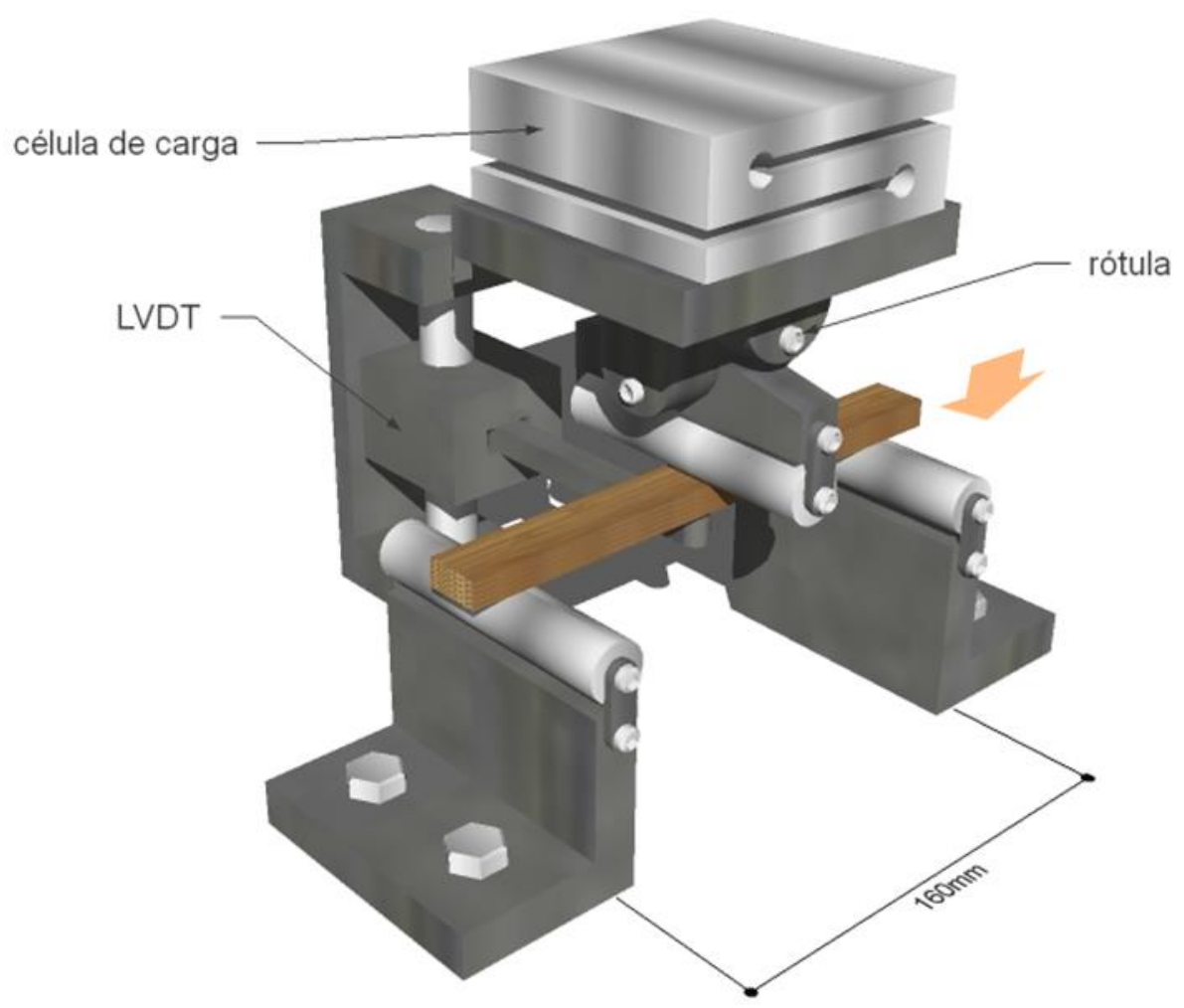

Figura 107: Setup de ensaio de flexão 3 pontos em laminado unidirecional de 5 camadas.

Por tratar-se de um ensaio com grandes deslocamentos, a flecha só é medida pelo LVDT até o seu limite $(10 \mathrm{~mm})$. Neste momento o ensaio é pausado e o LVDT é dissociado fisicamente do setup. Em todo o ensaio o deslocamento global é obtido pela própria MUE.

\subsection{Resultados}

A Tabela 27 apresenta a lista dos corpos-de-prova, seus modos de ruptura e algumas das propriedades físicas e mecânicas e a Figura 108 as curvas carga $x$ deslocamento de todos os ensaios, divididas por blocos de corpos-de-prova, de acordo com os empacotamentos de laminados. 
7.

Tabela 27: Quadro com os corpos-de-prova, algumas de suas propriedades físicas e mecânicas e uma descrição dos seus modos de ruptura.

\begin{tabular}{|c|c|c|c|c|c|c|c|}
\hline corpos-de-prova & $\begin{array}{c}\text { massa } \\
\text { (g) }\end{array}$ & $\begin{array}{c}\text { densidade } \\
\text { (g/cm3) }\end{array}$ & $\begin{array}{c}\text { umidade } \\
\text { superficial (\%) }\end{array}$ & modo de falha & $F_{\text {máx }}$ & $\mathbf{v}_{\text {máx }}$ & $\mathbf{E}$ \\
\hline LL1 & 33,83 & 0,79 & 0,00 & equilibrado & 1,34 & 3,35 & 15,24 \\
\hline LL2 & 33,64 & 0,79 & 0,00 & compressão & 1,35 & 3,72 & 14,12 \\
\hline LL3 & 34,32 & 0,80 & 0,00 & cisalhamento interlaminar & 1,32 & 3,53 & 13,76 \\
\hline LL4 & 33,79 & 0,78 & 0,00 & compressão & 1,30 & 3,17 & 15,04 \\
\hline LL5 & 34,43 & 0,78 & 0,00 & equilibrado & 1,41 & 3,29 & 15,76 \\
\hline LM1 & 35,95 & 0,83 & 0,00 & cisalhamento interlaminar & 1,60 & 3,71 & 16,18 \\
\hline LM2 & 36,24 & 0,85 & 0,00 & equilibrado & 1,69 & 3,43 & 18,78 \\
\hline LM3 & 36,95 & 0,86 & 0,00 & cisalhamento interlaminar & 1,50 & 2,88 & 19,94 \\
\hline LM4 & 37,43 & 0,87 & 0,00 & equilibrado & 1,62 & 3,47 & 17,88 \\
\hline LM5 & 37,79 & 0,89 & 0,00 & equilibrado & 1,72 & 3,70 & 18,21 \\
\hline LR1 & 43,77 & 1,04 & 0,00 & cisalhamento interlaminar & 2,02 & 2,23 & 37,19 \\
\hline LR2 & 43,10 & 1,04 & 0,00 & cisalhamento interlaminar & 2,26 & 2,98 & 31,41 \\
\hline LR3 & 42,57 & 1,03 & 0,00 & cisalhamento interlaminar & 2,18 & 3,57 & 26,26 \\
\hline LR4 & 42,01 & 0,99 & 0,00 & cisalhamento interlaminar & 2,00 & 3,05 & 26,53 \\
\hline LR5 & 42,01 & 1,00 & 0,00 & cisalhamento interlaminar & 2,15 & 2,93 & 29,47 \\
\hline LB1 & 36,91 & 0,86 & 0,00 & cisalhamento interlaminar & 1,79 & 3,37 & 20,58 \\
\hline LB2 & 36,70 & 0,85 & 0,00 & equilibrado & 1,57 & 3,55 & 16,70 \\
\hline LB3 & 36,90 & 0,86 & 0,00 & cisalhamento interlaminar & 1,69 & 3,63 & 17,85 \\
\hline LB4 & 36,54 & 0,85 & 0,00 & equilibrado & 1,56 & 3,58 & 16,35 \\
\hline LB5 & 38,06 & 0,88 & 0,00 & equilibrado & 1,71 & 3,86 & 16,97 \\
\hline
\end{tabular}


7.
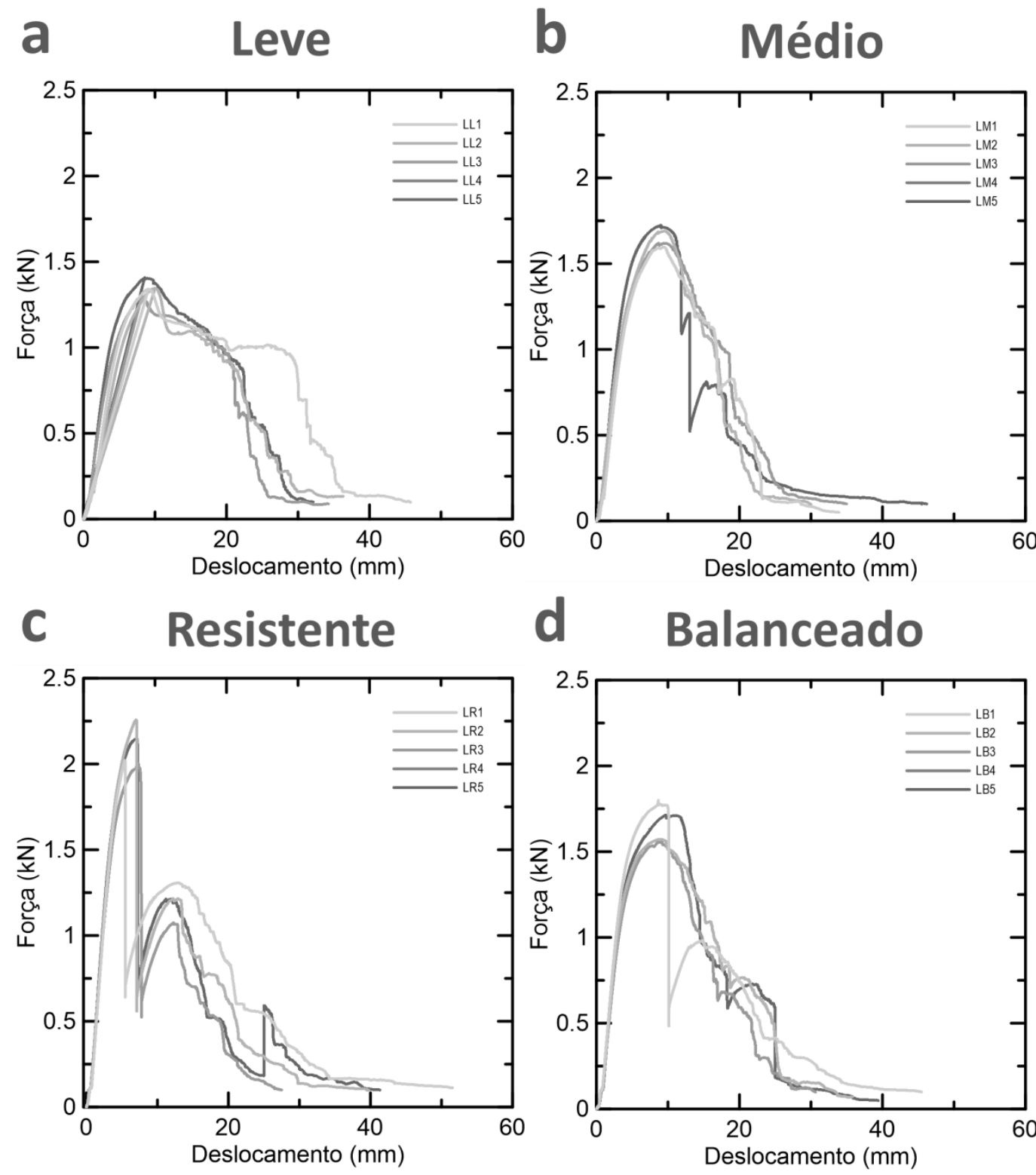

Figura 108: Gráficos carga $x$ deslocamento dos corpos-de-prova com diferentes empacotamentos: a) leve: composto por lâminas internas da porção central do colmo; b) médio: composto por lâminas provenientes da camada medial da porção central do bambu; c) resistente: proveniente de camadas externas da mesma porção e d) balanceado, que alia camadas externas nas faces mais distantes da linha neutra nos laminados e camadas internas no centro do corpo-de-prova.

Verifica-se que os comportamentos entre cada série de configurações de laminados ensaiados são bastante homogêneos, o que evidencia potencial de reprodutibilidade industrial e maior facilidade de parametrização técnica. Conforme previsto, a configuração resistente apresenta melhores propriedades mecânicas e a configuração leve as propriedades mais modestas. Surpreende, 
7.

no entanto a similaridades entre as curvas do empacotamento médio e do balanceado, que se repete nos números exibidos na Tabela 27.

A Tabela 28 apresenta um quadro resumo com as propriedades físicas e mecânicas e a Figura 109 curvas representativas do comportamento dos corposde-prova ensaiados à flexão.

Tabela 28: Sumário das propriedades físicas e mecânicas médias e seus respectivos desvios padrão, para os diferentes empacotamentos de laminados, bem como suas propriedades específicas.

\begin{tabular}{|l|c|c|c|c|c|c|c|c|c|c|}
\hline \multirow{2}{*}{ corpo-de-prova } & \multicolumn{2}{c|}{$\boldsymbol{V}_{\text {med/std }}$} & \multicolumn{2}{c|}{$\mathbf{F}_{\text {med/std }}$} & \multicolumn{2}{c|}{$\mathbf{V}_{\text {med/std }}$} & \multicolumn{2}{|c|}{$\mathbf{E}_{\text {med/std }}$} & $\mathbf{F} / \boldsymbol{V}$ & $\mathbf{E} / \boldsymbol{Y}$ \\
\hline LL & 0,78 & 0,02 & 1,35 & 0,04 & 3,38 & 0,20 & 15,04 & 0,59 & 1,73 & 19,28 \\
\hline LM & 0,86 & 0,02 & 1,66 & 0,05 & 3,58 & 0,13 & 17,76 & 0,97 & 1,93 & 20,65 \\
\hline LR & 1,01 & 0,02 & 2,11 & 0,10 & 2,79 & 0,33 & 31,15 & 3,89 & 2,09 & 30,84 \\
\hline LB & 0,86 & 0,02 & 1,66 & 0,09 & 3,60 & 0,16 & 17,69 & 1,53 & 1,93 & 20,57 \\
\hline
\end{tabular}

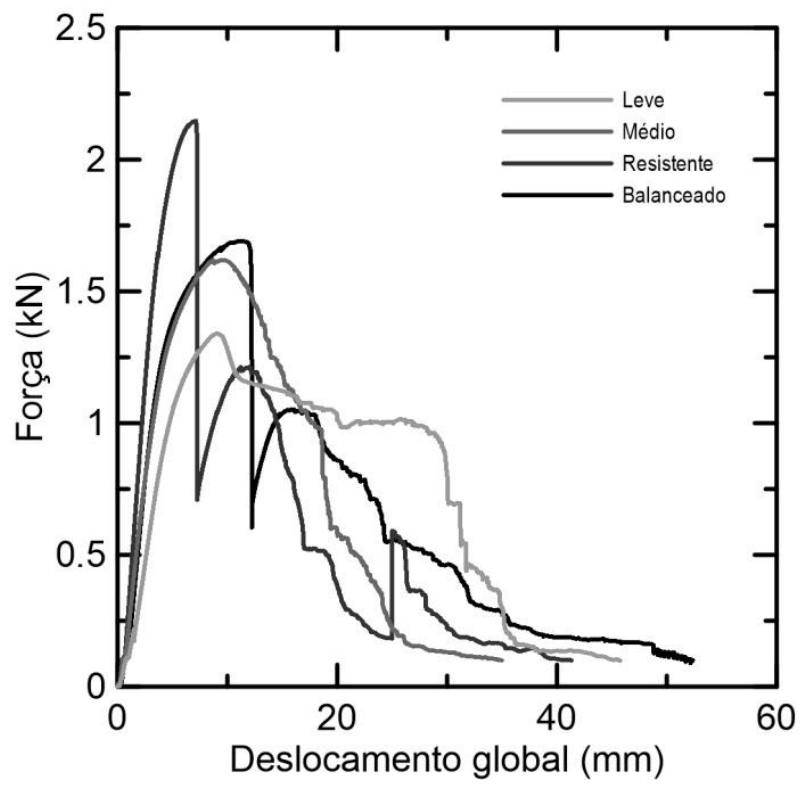

Figura 109: Gráficos carga x deslocamento de curvas representativas de corpos-deprova elaborados com os diferentes empacotamentos de laminados propostos.

As médias exibidas na Tabela 28 corroboram a semelhança entre os empacotamentos médio e balanceado e evidencia uma pequena diferença de rigidez entre eles, em favor do primeiro.

A Figura 110 exibe os corpos-de-prova ensaiados e permite observar rapidamente que um dos modos de falha típicos é o cisalhamento interlaminar. 


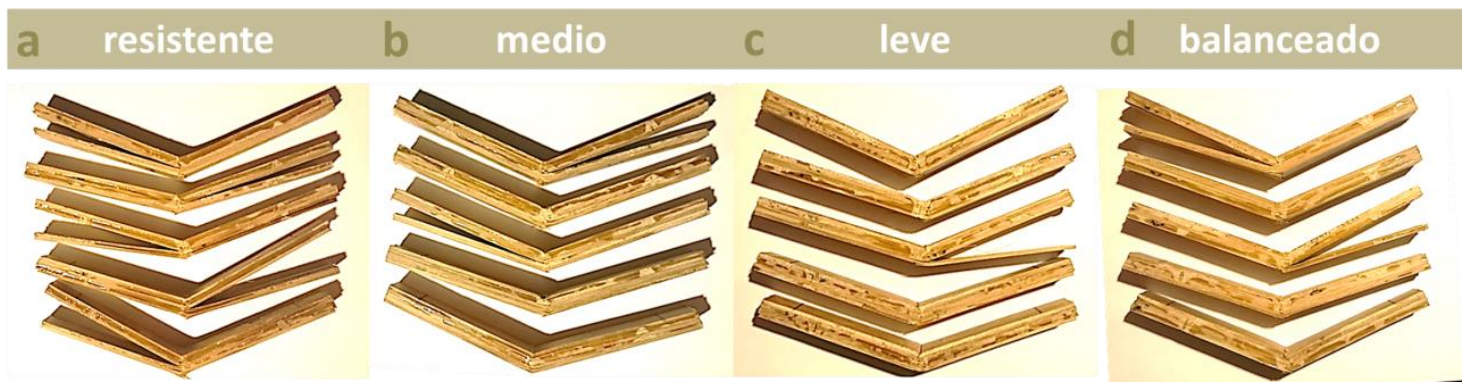

Figura 110: Corpos-de-prova ensaiados das configurações: a) resistente; b) médio; c) leve e d) balanceado.

Verifica-se que, na configuração resistente, dominada pela elevada fração volumétrica de fibras, $100 \%$ das falhas ocorrem por cisalhamento. Entretanto, diferentemente do observado nos ensaios de cisalhamento na linha da colagem, em todos os casos o adesivo permanece íntegro e a ruptura ocorre no bambu, próximo a uma das interfaces. Percebe-se ainda que as rupturas são mais fortemente influenciadas pela seção tracionada, dados que em todos os casos em que se observa falha por cisalhamento interlaminar a ruptura ocorre abaixo da linha neutra, em geral na segunda (entre cinco) lâmina a contar da face mais tracionada. Nas configurações média e balanceada a falha por cisalhamento cai para $40 \%$ e no empacotamento leve para $20 \%$, de modo que é possível inferir que quanto maior a resistência mecânica, maior a probabilidade de ruptura por cisalhamento interlaminar. Ressalta-se que este é um modo de ruptura frágil, de modo que, para aplicações em construção civil esta característica deve ser levada em consideração.

Outros modos de ruptura podem ser observados nos corpos-de-prova, o que é facilitado pelo detalhamento exibido na Figura 111.

Diante disso observa-se grande homogeneidade, sendo a maior parte das rupturas caracterizada pelo equilíbrio da falha entre as seções tracionada e comprimida. Na configuração leve, entretanto, dado ao elevado teor de vazios e baixa fração volumétrica de fibras, $40 \%$ das falhas ocorrem na seção comprimida.

Em uma análise ampla, confirma-se as observações feitas acerca dos ensaios de flexão das lâminas em que quanto maior a fração volumétrica de fibras e menor a de vazios, mais o sistema de falhas será regido por esforços de tração e, por oposto, quanto maior o teor de vazios e menor a fração volumétrica de fibras, mais as rupturas se darão na seção comprimida da peça ensaiada. 
7.

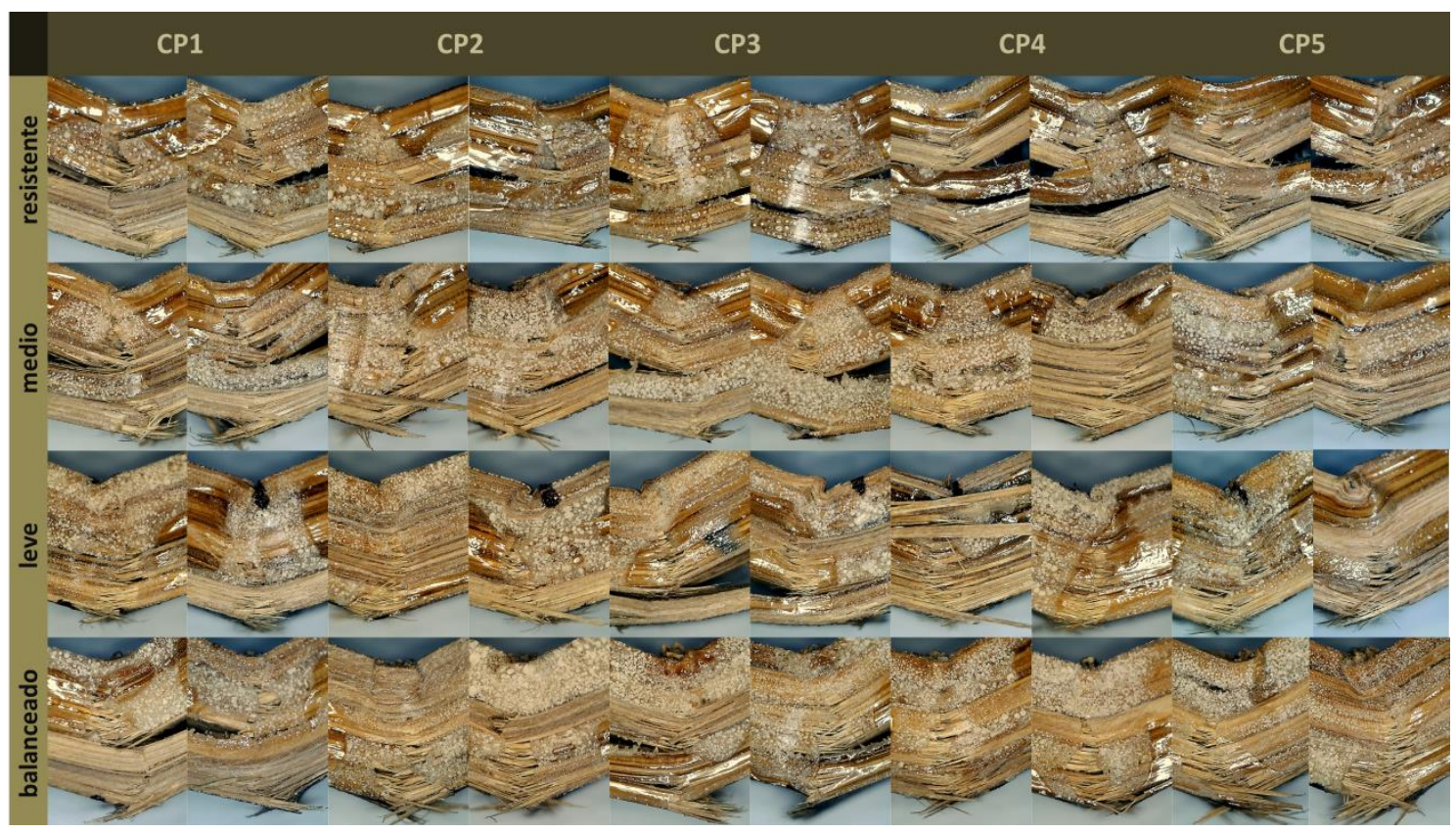

Figura 111: Detalhes dos modos de ruptura dos corpos-de-prova ensaiados.

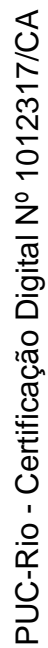




\section{8. Modelagem e Análise de Laminados via Elementos Finitos}

Este capítulo refere-se à modelagem numérica dos laminados e à sua comparação com os resultados obtidos com os ensaios mecânicos do Capítulo anterior, buscando simular o mais adequadamente possível o comportamento dos laminados estudados, de modo a permitir posteriormente a modelagem de sistemas mais complexos utilizando estes materiais, sob parâmetros adequados.

Para tanto, foi utilizado o programa comercial de modelagem e análise numérica pelo Método dos Elementos Finitos (MEF), SAP 2000 versão 17, com o qual foram elaborados modelos de diferentes complexidades e com condições de contorno distintas para simular os ensaios de flexão 3 pontos para os diversos empacotamentos propostos, de modo a buscar traçar uma envoltória de esforços simplificada, baseada nos parâmetros obtidos na prática laboratorial e nas medições e caracterizações dos corpos-de-prova, fundamentalmente pesos específicos e módulos de elasticidade (Tabela 29), comparando os deslocamentos previstos por cada modelo com os obtidos experimentalmente.

Tabela 29: Pesos específicos e módulos de elasticidade médios utilizados como parâmetro nos modelos em MEF.

\begin{tabular}{|c|c|c|}
\hline empacotamentos & $\boldsymbol{Y}_{\text {med }}$ & $\mathbf{E}_{\text {med }}$ \\
\hline Laminado Leve & 0,78 & 15,04 \\
\hline Laminado Médio & 0,86 & 17,76 \\
\hline Laminado Resistente & 1,01 & 31,15 \\
\hline Laminado Balanceado & 0,86 & 17,69 \\
\hline
\end{tabular}

A priori foram realizadas diversas modelagens teste em dois programas comerciais: SAP 2000 e STAAD Pro (Bentley), no intuito de verificar a melhor manera de parametrizar os materiais e prevenir erros de nexo dos programas, considerando as suas limitações. O programa STAAD Pro apresentou erros internos que não permitiram concluir a análise estrutural em modelos sólidos, utilizando os parâmetros de peso específico e módulo de elasticidade obtidos experimentalmente, tendo sido, portanto descartado dos resultados. Ao definir os 
8.

parâmetros do material, utilizou-se parâmetros referentes a material isotrópico e material ortotrópico, entretanto, para o tipo de modelo analisado, os resultados não apresentaram diferença. Assim, adotou-se a configuração de material isotrópico, visando reduzir trabalho e custo computacional.

Considerando as diferentes configurações finais, foram elaborados 32 modelos, cujas especificidades são esclarecidas na sequência.

\subsection{Modelo de viga}

O modelo mais simples desenvolvido foi um modelo de viga discretizado em 10 divisões, seguindo as configurações do ensaio mecânico realizado (Figura 112). O modelo simula uma viga laminada com $200 \mathrm{~mm}$ de comprimento, secão de $20 \mathrm{~mm}$ (horizontal) $\times 10 \mathrm{~mm}$ (vertical), com um vão de $160 \mathrm{~mm}$ centralizado e carregamento aplicado no centro do vão.

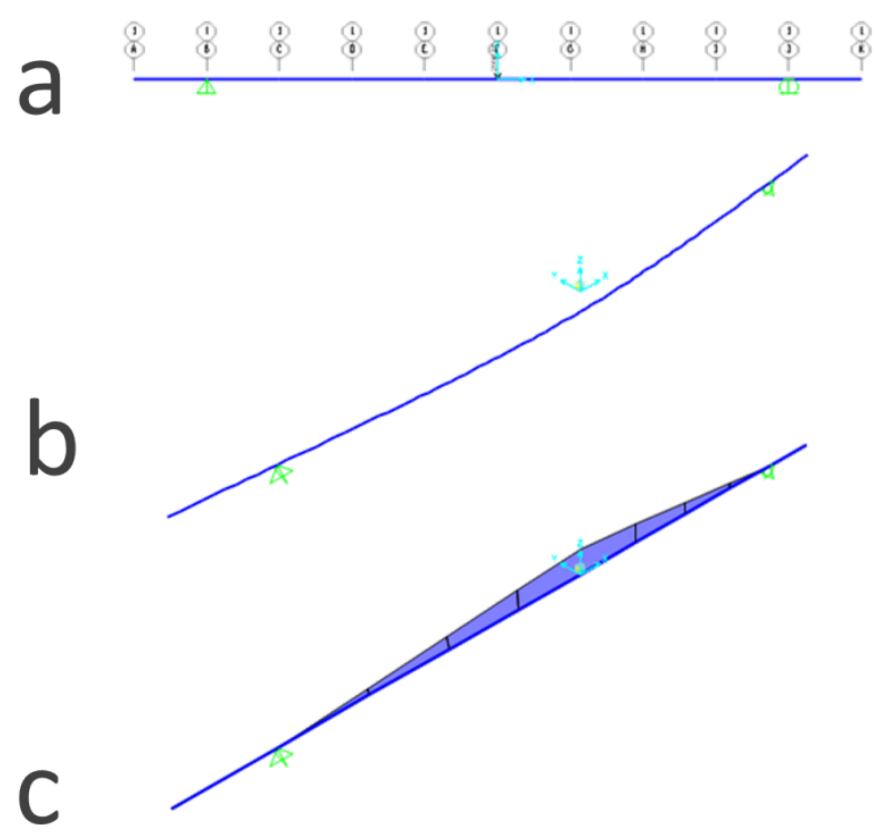

Figura 112: imagem do modelo de viga elaborado: a) evidenciando a discretização e a posição dos apoios; b) Exibindo sua configuração deformada após a aplicação de esforço no centro do vão; c) diagrama de momento fletor associado ao modelo.

As propriedades do material foram configuradas em 4 diferentes modelos, buscando atender aos diferentes empacotamentos de laminados (Tabela 29) e duas condições de contorno limites foram aplicadas em modelos específicos, 
8.

visando estabelecer os contornos da envoltória: apoio fixo-apoio e apoio fixoapoio fixo, totalizando 8 modelos. Foram aplicados carregamentos de 0,25 a 2 $\mathrm{kN}$, com passo de variação de $0,25 \mathrm{kN}$ para permitir traçar a curva.

\subsection{Modelo de placa}

Os mesmos parâmetros anteriormente descritos foram adaptados para um modelo de placa, discretizado em 10 elementos (Figura 113), com dimensões de $200 \mathrm{~mm}$ de comprimento $\times 20 \mathrm{~mm}$ de largura e $10 \mathrm{~mm}$ de espessura, adotandose os ajustes necessários, como discretizar os apoios e as aplicações de carregamento de acordo com todos os nós transversais nas regiões pertinentes, de modo a melhor emular o setup do ensaio mecânico.

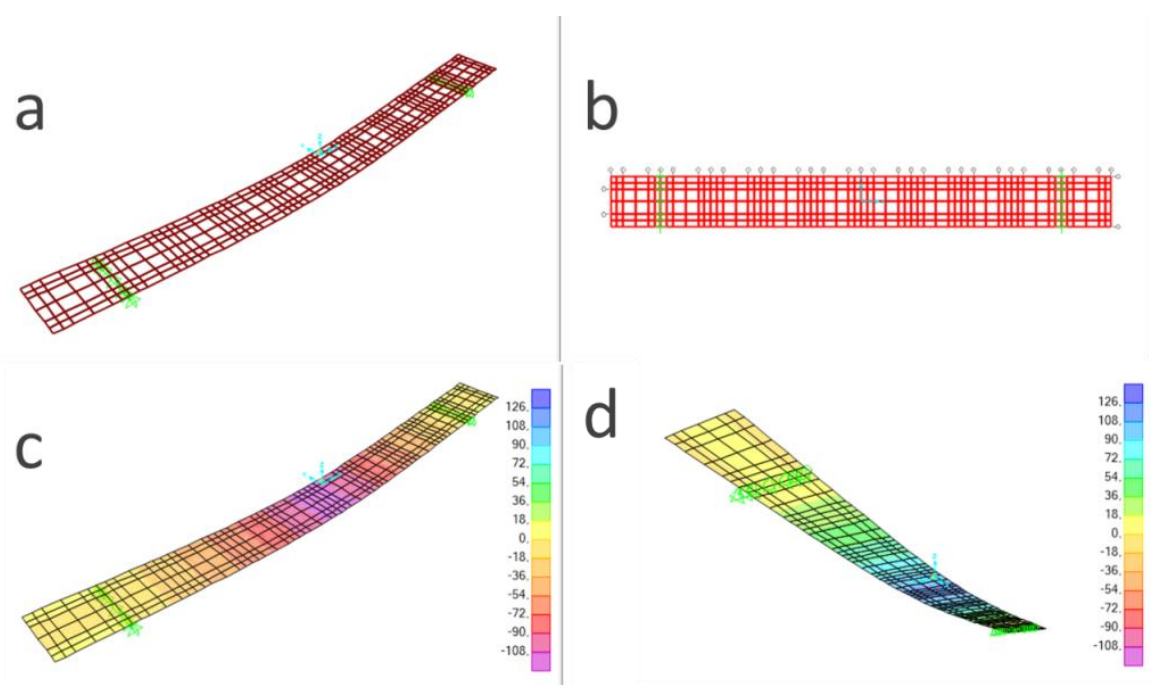

Figura 113: modelo de placa elaborado: a) configuração deformada; b) discretização dos elementos utilizados; c) e d) tomadas superior e inferior do modelo com sua distribuição de tensões aplicada.

\subsection{Modelo sólido}

Novamente adaptam-se os parâmetros anteriormente descritos para um modelo sólido, discretizado em 40 elementos iguais de $10 \mathrm{~mm} \times 10 \mathrm{~mm} \times 10 \mathrm{~mm}$, dois a dois, (Figura 114), adotando-se os ajustes necessários, como discretizar os apoios e as aplicações de carregamento em todos os nós transversais nas regiões pertinentes, de modo a melhor emular o setup do ensaio mecânico. 
8.
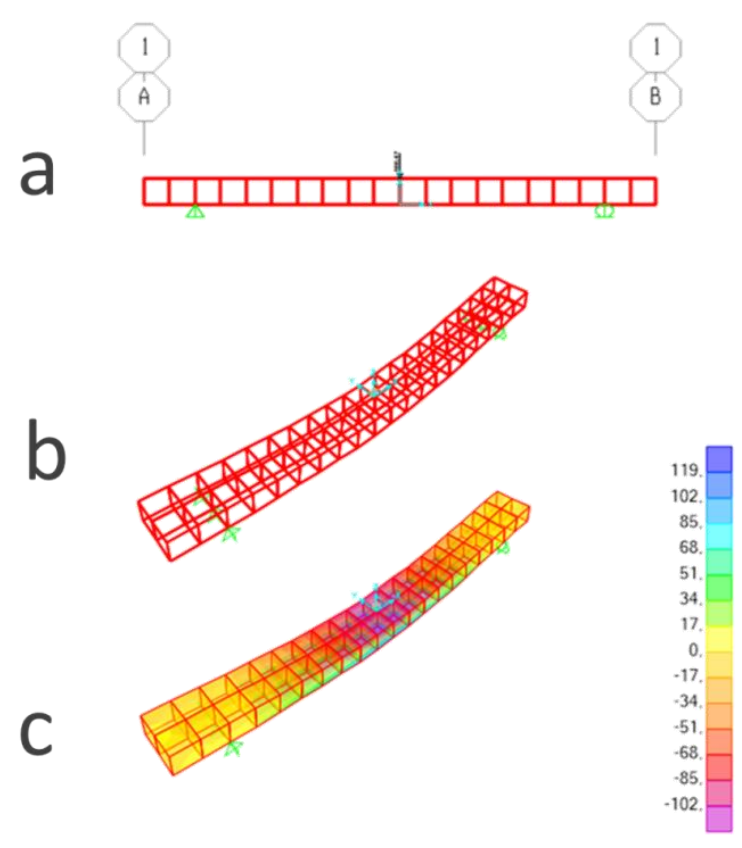

Figura 114: modelo sólido: a) discretização dos elementos utilizados; b) configuração deformada e c) tomada superior do modelo com distribuição de tensões aplicada.

\subsection{Modelo sólido (lâminas)}

Para este modelo (Figura 115) foram utilizados os parâmetros das lâminas que compõem cada empacotamento (Tabela 30), buscando simular mais adequadamente cada uma das configurações. Para este modelo foram utilizados 200 elementos sólidos idênticos, com $10 \mathrm{~mm} \times 10 \mathrm{~mm} \times 2 \mathrm{~mm}$, procurando reproduzir o empilhamento das lâminas.

Tabela 30: Parâmetros utilizados para as lâminas do modelo, agrupados de acordo com a configuração do laminado.

\begin{tabular}{|c|c|c|}
\hline camadas & $\boldsymbol{Y}_{\text {med }}$ & $\mathbf{E}_{\text {med }}$ \\
\hline $\mathbf{M E}$ & 1,00 & 15,01 \\
\hline $\mathbf{M M}$ & 0,81 & 12,49 \\
\hline $\mathbf{M I}$ & 0,77 & 10,80 \\
\hline
\end{tabular}


8.
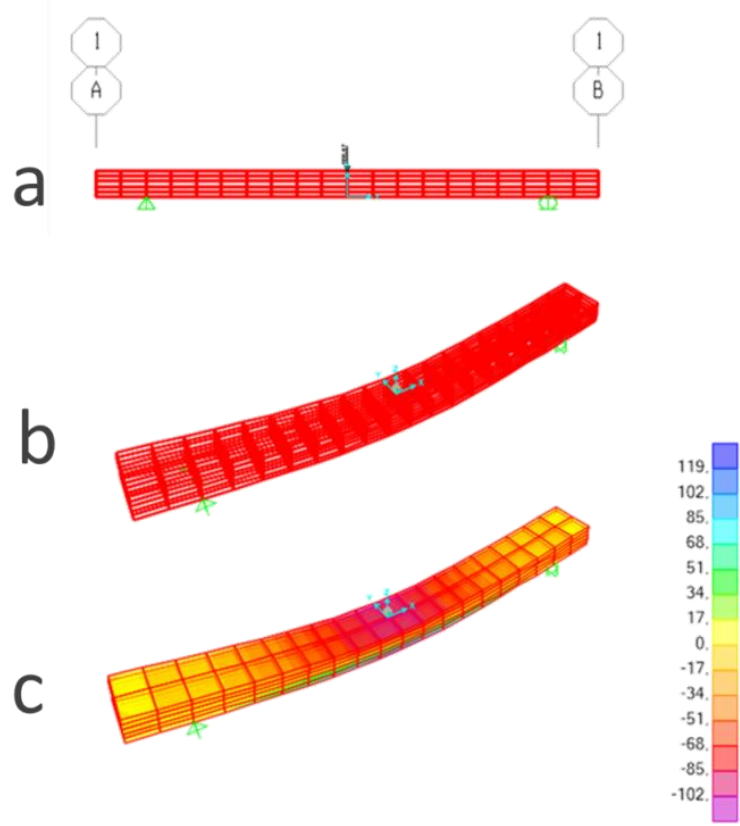

Figura 115: modelo sólido elaborado com as propriedades das lâminas isoladas: a) discretização dos elementos utilizados; b) configuração deformada e c) tomada superior do modelo com distribuição de tensões aplicada.

\subsection{Resultados}

A Tabela 31 apresenta um sumário com todos os modelos desenvolvidos, no intuito de permitir cruzar dados de carregamento aos deslocamentos previstos, de acordo com o empacotamento do laminado e as condições de contorno simuladas. 
8.

Tabela 31: Quadro resumo dos modelos, seus parâmetros, condições de contorno e os deslocamentos obtidos para cada caso.

\begin{tabular}{|c|c|c|c|c|c|c|c|c|c|c|c|}
\hline \multicolumn{2}{|c|}{$\begin{array}{l}\text { Condições de } \\
\text { contorno }\end{array}$} & $\begin{array}{l}\text { apoio } \\
\text { apoio }\end{array}$ & $\begin{array}{l}\text { apoio } \\
\text { apoio }\end{array}$ & $\begin{array}{l}\text { apoio } \\
\text { fixo } \\
\text { apoio }\end{array}$ & $\begin{array}{l}\text { apoio } \\
\text { fixo } \\
\text { apoio } \\
\text { fixo }\end{array}$ & $\begin{array}{l}\text { apoio } \\
\text { fixo } \\
\text { apoio }\end{array}$ & $\begin{array}{l}\text { apoio } \\
\text { fixo } \\
\text { apoio } \\
\text { fixo }\end{array}$ & $\begin{array}{c}\text { apoio } \\
\text { fixo } \\
\text { apoio }\end{array}$ & $\begin{array}{l}\text { apoio } \\
\text { fixo } \\
\text { apoio } \\
\text { fixo }\end{array}$ & $\begin{array}{c}\text { apoio } \\
\text { fixo } \\
\text { apoio }\end{array}$ & $\begin{array}{l}\text { apoio } \\
\text { fixo } \\
\text { apoio } \\
\text { fixo }\end{array}$ \\
\hline \multirow{2}{*}{ 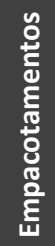 } & \multirow{2}{*}{ Força (kN) } & \multicolumn{2}{|c|}{$\begin{array}{l}\text { Deslocamento } \\
\text { Ensaiado (mm) }\end{array}$} & \multirow{2}{*}{\multicolumn{2}{|c|}{$\begin{array}{c}\text { Deslocamento } \\
\text { Modelo viga SAP } \\
\text { (mm) }\end{array}$}} & \multirow{2}{*}{\multicolumn{2}{|c|}{$\begin{array}{l}\text { Deslocamento } \\
\text { Modelo lâmina } \\
\text { única SAP (mm) }\end{array}$}} & \multicolumn{2}{|c|}{$\begin{array}{l}\text { Deslocamento } \\
\text { Modelo sólido } 1 \\
\text { SAP (mm) }\end{array}$} & \multicolumn{2}{|c|}{$\begin{array}{c}\text { Deslocamento } \\
\text { Modelo sólido } 2 \\
\text { SAP (mm) }\end{array}$} \\
\hline & & & & & & & & & & & \\
\hline \multirow{8}{*}{ త্ } & 0,25 & 1,73 & 0,34 & 1,07 & 1,07 & 0,87 & 0,88 & 0,87 & 0,38 & 1,19 & 0,54 \\
\hline & 0,50 & 2,62 & 0,69 & 2,13 & 2,13 & 1,75 & 1,76 & 1,74 & 0,77 & 2,37 & 1,08 \\
\hline & 0,75 & 3,52 & 1,05 & 3,19 & 3,19 & 2,62 & 2,64 & 2,60 & 1,15 & 3,56 & 1,62 \\
\hline & 1,00 & 4,71 & 1,52 & 4,26 & 4,26 & 3,49 & 3,52 & 3,47 & 1,53 & 4,75 & 2,17 \\
\hline & 1,25 & 7,02 & 2,47 & 5,32 & 5,32 & 4,37 & 4,40 & 4,34 & 1,92 & 5,93 & 2,71 \\
\hline & 1,50 & - & - & 6,38 & 6,38 & 5,24 & 5,28 & 5,21 & 2,30 & 7,12 & 3,25 \\
\hline & 1,75 & - & - & 7,45 & 7,45 & 6,11 & 6,16 & 6,08 & 2,68 & 8,31 & 3,79 \\
\hline & 2,00 & - & - & 8,51 & 8,51 & 6,99 & 7,04 & 6,94 & 3,07 & 9,49 & 4,33 \\
\hline \multirow{8}{*}{.을 } & 0,25 & 1,08 & 0,25 & 0,87 & 0,87 & 0,71 & 0,71 & 0,71 & 0,31 & 1,03 & 0,47 \\
\hline & 0,50 & 1,70 & 0,52 & 1,73 & 1,73 & 1,42 & 1,43 & 1,41 & 0,62 & 2,05 & 0,94 \\
\hline & 0,75 & 2,39 & 0,79 & 2,59 & 2,59 & 2,13 & 2,14 & 2,12 & 0,93 & 3,08 & 1,41 \\
\hline & 1,00 & 3,22 & 1,13 & 3,46 & 3,46 & 2,84 & 2,86 & 2,82 & 1,25 & 4,11 & 1,87 \\
\hline & 1,25 & 4,31 & 1,58 & 4,32 & 4,32 & 3,55 & 3,57 & 3,53 & 1,56 & 5,13 & 2,34 \\
\hline & 1,50 & 6,52 & 2,54 & 5,19 & 5,19 & 4,26 & 4,29 & 4,23 & 1,87 & 6,16 & 2,81 \\
\hline & 1,75 & - & - & 6,05 & 6,05 & 4,97 & 5,00 & 4,94 & 2,18 & 7,19 & 3,28 \\
\hline & 2,00 & - & - & 6,92 & 6,92 & 5,68 & 5,72 & 5,64 & 2,49 & 8,21 & 3,75 \\
\hline \multirow{8}{*}{ 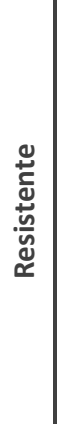 } & 0,25 & 0,92 & 0,19 & 0,52 & 0,53 & 0,43 & 0,43 & 0,43 & 0,19 & 0,85 & 0,38 \\
\hline & 0,50 & 1,35 & 0,38 & 1,04 & 1,06 & 0,86 & 0,86 & 0,85 & 0,38 & 1,71 & 0,75 \\
\hline & 0,75 & 1,78 & 0,58 & 1,56 & 1,60 & 1,28 & 1,29 & 1,28 & 0,56 & 2,56 & 1,13 \\
\hline & 1,00 & 2,23 & 0,78 & 2,09 & 2,13 & 1,71 & 1,72 & 1,70 & 0,75 & 3,41 & 1,51 \\
\hline & 1,25 & 2,70 & 0,99 & 2,61 & 2,66 & 2,14 & 2,16 & 2,13 & 0,94 & 4,27 & 1,88 \\
\hline & 1,50 & 3,26 & 1,24 & 3,13 & 3,19 & 2,57 & 2,59 & 2,55 & 1,13 & 5,12 & 2,26 \\
\hline & 1,75 & 4,06 & 1,57 & 3,65 & 3,72 & 3,00 & 3,02 & 2,98 & 1,31 & 5,98 & 2,64 \\
\hline & 2,00 & 5,21 & 2,08 & 4,17 & 4,26 & 3,42 & 3,45 & 3,40 & 1,50 & 6,83 & 3,02 \\
\hline \multirow{8}{*}{ 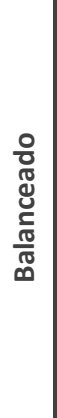 } & 0,25 & 1,27 & 0,23 & 0,89 & 0,89 & 0,73 & 0,74 & 0,73 & 0,32 & 0,85 & 0,39 \\
\hline & 0,50 & 1,83 & 0,48 & 1,78 & 1,78 & 1,46 & 1,47 & 1,45 & 0,64 & 1,71 & 0,78 \\
\hline & 0,75 & 2,42 & 0,74 & 2,67 & 2,67 & 2,19 & 2,21 & 2,18 & 0,96 & 2,56 & 1,17 \\
\hline & 1,00 & 3,11 & 1,03 & 3,56 & 3,56 & 2,92 & 2,94 & 2,90 & 1,28 & 3,41 & 1,56 \\
\hline & 1,25 & 4,08 & 1,43 & 4,45 & 4,45 & 3,65 & 3,68 & 3,63 & 1,60 & 4,27 & 1,95 \\
\hline & 1,50 & 6,19 & 2,31 & 5,34 & 5,34 & 4,38 & 4,41 & 4,35 & 1,92 & 5,12 & 2,34 \\
\hline & 1,75 & - & - & 6,22 & 6,22 & 5,11 & 5,15 & 5,08 & 2,24 & 5,98 & 2,73 \\
\hline & 2,00 & - & - & 7,11 & 7,11 & 5,84 & 5,88 & 5,80 & 2,56 & 6,83 & 3,12 \\
\hline
\end{tabular}


8.

Os dados provenientes da tabela permitem elaborar gráficos para as diferentes configurações de laminados (Figura 116). Somente foram plotados os resultados de deslocamento dos modelos sólidos, visto que os demais não conseguiram se aproximar dos resultados experimentais.
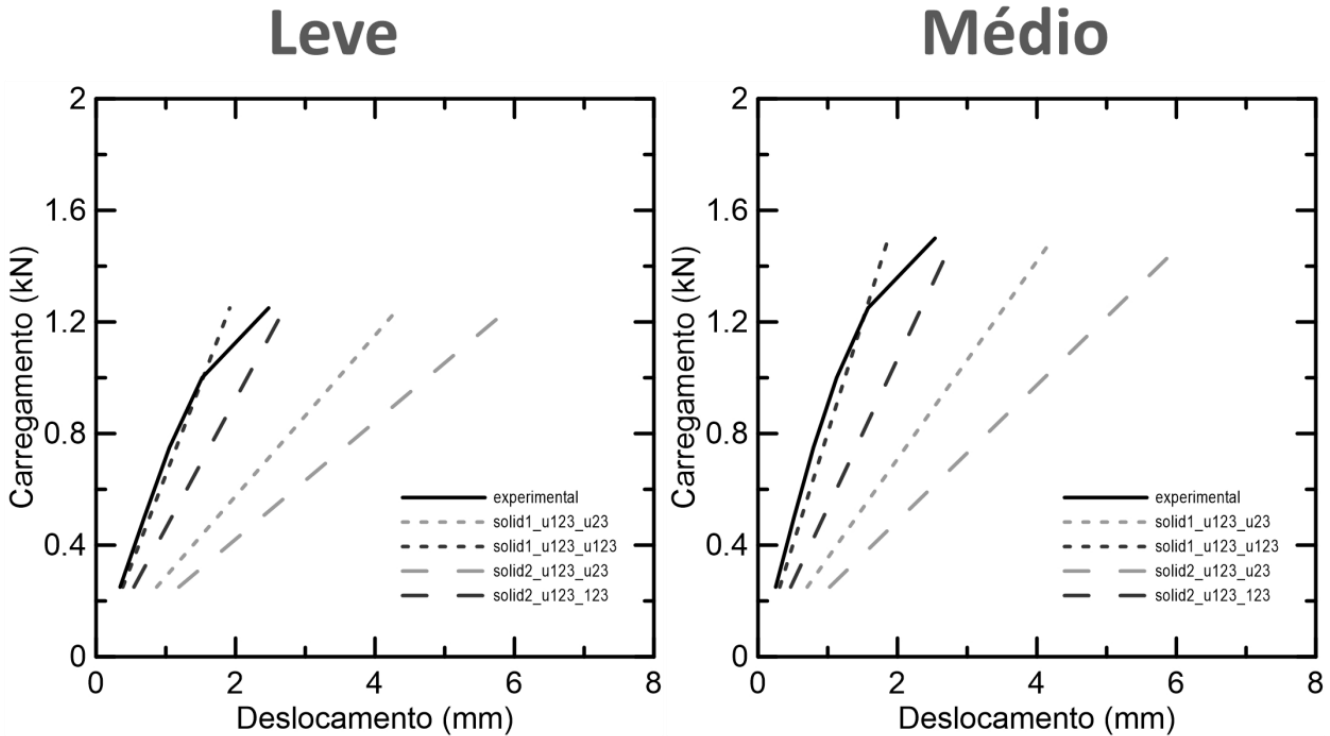

Resistente

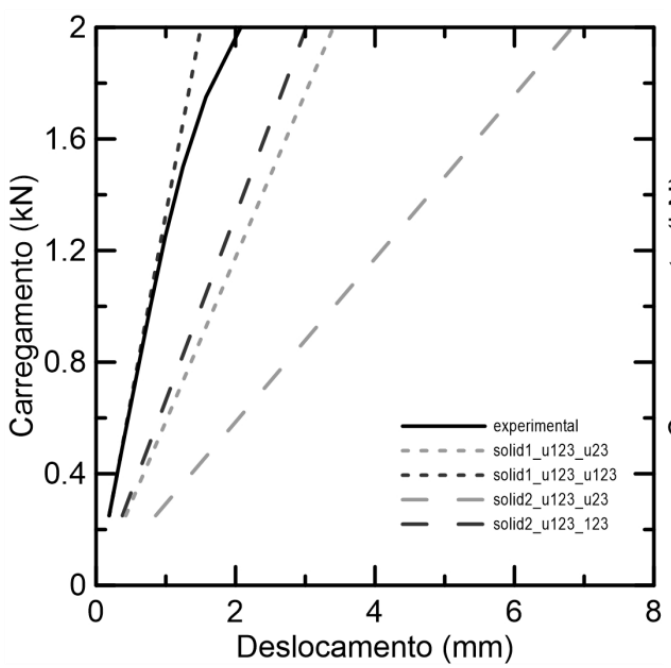

Balanceado

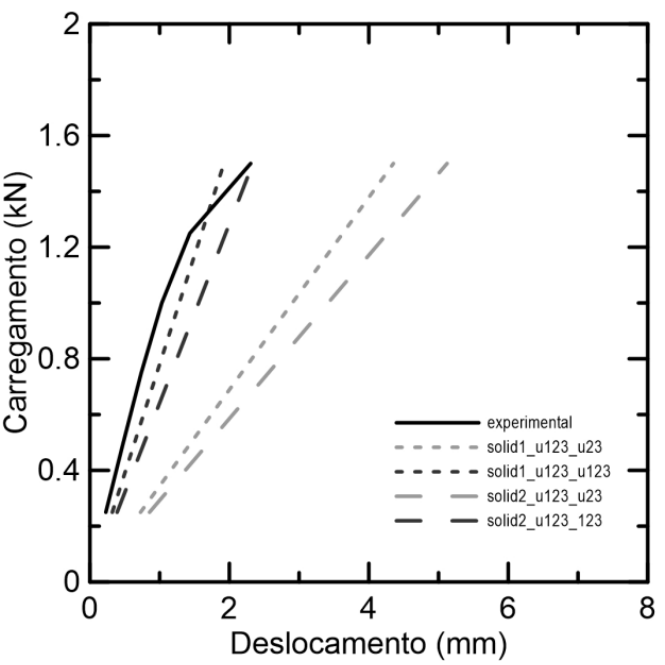

Figura 116: comparação entre as envoltórias de esforços simplificadas obtidas por simulação e os deslocamentos obtidos experimentalmente, para as diversas configurações de laminados propostas.

Analisando os gráficos, percebe-se que os modelos não foram capazes de simular adequadamente os laminados, exceto pela configuração resistente, uma vez que os resultados experimentais apresentam rigidez superior ao limite 
8.

superior obtido nos modelos, por meio das condições de contorno apoio fixoapoio fixo. Talvez seja necessário buscar sofwares mais específicos, com mais recursos, que permitam simular adequadamente materiais laminados de baixa densidade e alta resistência. Existe ainda a possibilidade de tentar calibrar os modelos inserindo "molas" nos apoios, o que aumentaria a rigidez do sistema. 


\section{9. \\ Conclusões, recomendações e sugestões para trabalhos futuros}

Entende-se que as hipóteses apresentadas ao início deste trabalho foram integralmente confirmadas e as soluções propostas atendem parcialmente às demandas decorrentes.

Mais especificamente, verificou-se que os modos de ruptura típicos dos ensaios de tração simples correntes não condizem com o esforço que devem traduzir e que o protocolo de ensaio proposto, baseado na norma ASTM D 3039 atende adequadamente à avaliação experimental à tração de bambus de diferentes espessuras de parede, tanto em ensaios de controle, como em verificação de material processado. O protocolo de ensaios de compressão proposto foi bem sucedido, embora possa ser melhorado, atendendo também tanto a ensaios de controle como de lâminas para uso isolado ou para a confecção de laminados. De modo análogo os ensaios de cisalhamento para lâminas atenderam ao proposto, mas podem ser aperfeiçoados, elaborando uma pinça mais adequada e alterando as condições de contorno do ensaio.

A avaliação dos modos de ruptura, em especial das laminas e laminados, foi bastante profícua, permitindo discretizar o comportamento das diversas camadas e porções do bambu.

A classificação funcional dos poros do bambu foi confirmada por dois métodos, um dos quais proposto neste trabalho, de aplicação simples e com resultado bastante próximo da realidade, baseado em ensaios de variação de umidade em lâminas sequenciais. A porosidade tem influência direta nas propriedades específicas do material, uma vez que influi na determinação da sua densidade. A porosidade parece ter influência também sobre as propriedades do material, todavia não foi possível quantificar esta influência, dado que há muitas variáveis envolvidas. A fração volumétrica de fibras permanece sendo determinante para as propriedades do bambu.

Foram confeccionados com sucesso materiais com propriedades diversas, engenheirados a partir de partes diferentes do bambu, mas utilizando a mesma tecnologia de laminação e prensagem, o que torna o processo reprodutível e estimula o uso de partes do bambu que usualmente são descartadas. Todavia o 
9.

adesivo deve ser mais resistente, uma vez que na situação descrita neste trabalho diversos corpos-de-prova tiveram ruptura nas linhas de colagem. Com um adesivo mais resistente as diferenças de resistência e rigidez entre as diferentes composições de laminados tende a se tornar mais evidente.

Para trabalhos futuros, recomenda-se que os ensaios de compressão baseados na ASTM D3410, tanto os de controle, como os específicos para as lâminas, sejam conduzidos em um setup sem rótulas. O mesmo se aplica aos ensaios propostos para avaliação de cisalhamento das lâminas.

O conjunto de estabilizadores para os ensaios para o cisalhamento das lâminas deve ser reconfeccionado em material metálico, preferencialmente duralumínio. A madeira tende a se deformar na área de contato com o corpo-deprova, podendo ocasionar folgas que induzem a modos de ruptura que não traduzem adequadamente o esforço de cisalhamento.

Novas tomografias devem ser realizadas em maior quantidade e com maior controle, possibilitando obter dados quantitativos com maior eficácia.

Sugere-se que, para pesquisas subsequentes se expanda o protocolo de ensaios, incluindo condições de saturação; que seja conduzido um processo de nanoindentação para a determinação das propriedades mecânicas dos constituintes do bambu, de tal modo que, com mais dados, se tente mais uma vez quantificar a influência dos vazios nas suas propriedades mecânicas, via aproximações elaboradas para materiais compósitos; que seja estudada mais amiúde uma maneira de modelar numericamente adequadamente o bambu e seus subprodutos processados, utilizando softwares de pesquisa, dotados de maiores recursos. 
10.

Referências Bibliográficas

1. POPE, J.; ANNANDALE, D.; MORRISON-SAUNDERS, A. Conceptualising sustainability assessment. Environmental Impact Assessment Review, 2004.

2. SCHMANDT, J. Bringing sustainability science to water basin management. Energy, 2006.

3. ISAGI, Y; KAWAHARA, T; KAMO, K; ITO, H. 1997. Net production and carbon cycling in a bamboo Phyllostachys pubescens stand. Momoyama, Fushimi, Kyoto, Japão: Kansai Research Center, Forestry and Forest Products Research Institute, 1997.

4. INTERNATIONAL ORGANIZATION FOR STANDDARDIZATION. ISO 22157. International Standard 22157 Bamboo - Determination of physical and mechanical properties. [S.I.]. 2004.

5. LEVY NETO, F.; PARDINI, L. C. Compósitos Estruturais Ciência e Tecnologia. 1. ed. São Paulo: Editora Edgard Blücher, 2006. 313 p. ISBN 85-212-0397-7.

6. GIBSON, R. F. Principles of Composite Material Mechanics. New York: CRC Press, 2011. ISBN 1439850054, 9781439850053.

7. JONES, R. M. Mechanics of composite materials. Washington: Scripta Book, 1975.

8. SILVA, R. V. Compósito de resina poliuretano derivada de óleo de mamona e fibras vegetais. São Carlos: USP São Carlos. 2003.

9. SMITH, C. B. Some New Types of Ortothropic Plates Laminated of Orthotropic Material. Journal of Applied Mechanics, 1953. 286-288.

10. PISTER, K. S.; DONG, S. B. Elastic Bending of Layered Plates. Journal of Engineering Mechanics Division, 1959. 1-10.

11. REISSENER, E.; STAVSKY, Y. Bending and stretching of certain types of heterogeneous aeolotropic elastic plates. Journal of Applied Mechanics, 1961. 402-408.

12. STAVSKY, Y. On the general theory of heterogeneous aeolotropic plates. Aeronautical Quarterly, 1964. 29-28. 
10.

13. LEKHNITSKII, S. G. Anisotropic plates. Tradução de S. W. Tsai e T. Cheron. 2. ed. New York: Gordon and Breach Science Publishers, 1968.

14. STAVSKY, Y.; HOFF, N. J. Mechanics of composite structures. Composite Engineering Laminates. Cambridge, 1969.

15. WEGST, U. G. K.; ASHBY, M. F. The mechanical efficiency of natural materials. Philosophical Magazine, 84, 2004.

16. BRITEZ, C. A.; NOGUEIRA, V. Interrelação entre as propriedades e a microestrutura das madeiras. In: Princípios da Ciência dos Materiais aplicados aos materiais de construção civil. São Paulo: USP, 2006.

17. MONTANA QUÍMICA S.A. Biodeterioração e preservação de madeiras. São Paulo: [s.n.], 1991. 75 p.

18. SUN, R. C.; SUN, X. F.; MA, X. H. Effect of ultrasound on the structural and physiochemical properties of organosolv soluble hemicelluloses from wheat straw. Ultrason., Sonochem. , 2002. 95-101.

19. FREUDENBERG, K. Lignin: its constitution and formation from phydroxycinnamyl alcohols. Science, 1965. 595-600.

20. WEN, J.L.; XUE, B.L.; XU, F.; SUNA, R.C.; PINKERT, A. Unmasking the structural features and property of lignin from bamboo. Industrial Crops and Products, 2013. 332- 343.

21. SCURLOCK, J. M. O.; DAYTON, D. C.; HAMES, B. Bamboo: an overlooked biomass resource? Biomass Bioenergy , 2000. 229-244.

22. CHO, C.H.; LEE, K.H.; KIM, J.S.; KIM, Y.S. Micromorphological Characteristics of Degradation in Bamboo (Phyllostachys pubescens) fibers degraded by a brown rot fungus (Gloeophyllum trabeum). Journal of Wood Science, 2008. 261-265.

23. PARAMESWARAN, N.; LIESE, W. On the fine structure of bamboo fibres. Science and Technology, 1976. 231-246.

24. ZHANG, X.; YU, H.; HUANG, H.; LIU, Y. Evaluation of biological pretreatment with white rot fungi for the enzymatic hydrolysis of bamboo culms. International Biodeterioration and Biodegradation, 2007. 159-164.

25. SUPRAPTI, S. Decay resistance of five Indonesian bamboo species against fungi. Journal of Tropical Forest Science, 2010. 287-294.

26. ASHAARI, Z.; MAMAT, N. Traditional treatment of Malaysian bamboos: resistance towards white rot fungus and durability in service. Pakistan Journal of Biological Sciences, 2000. 1453-1458. 
27. ERAKHRUMEN, A. A. Evaluating the efficacy of neem (Azadirachta indica A. Juss) seed oil treatment for Bambusa vulgaris Schrad against Pycnoporus sanguineus (L. ex Fr.) Murr. using static bending strength properties. Forest Pathology, 2012. 191-198.

28. GIRON, M. Y.; GARCIA, C. M.; MORRELLZ, J. J. Bioprotection of bamboo culms against stain fungi in bamboo using Pseudomonas fluorescens. Chiangmai, 2000.

29. SALIM, R.; WAHAB, R.; ASHAARI, Z. Effect of oil heat treatment on chemical constituents of semantan bamboo (Gigantochloa scortechinii Gamble). Journal of Sustainable Development, 2008. 91-98.

30. SUN, F.; ZHOU, Y.; BAO, B.; CHEN, A.; DU, C. Influence of solvent treatment on mould resistance of bamboo. BioResources, 2011. 20912100.

31. OKAHISA, Y.; YOSHIMURA, T.; IMAMURA, Y. Seasonal and heightdependent fluctuation of starch and free glucose contents in moso bamboo (Phyllostachys pubescens) and its relation to attack by termites and decay fungi. Journal of Wood Science 52, 2006. 445-451.

32. FUENTES, C.A.; TRAN, L.Q.N.; DUPONT-GILLAIN, C.; VANDERLINDEN, W.; FEYTER, S. D. Wetting behaviour and surface properties of technical bamboo fibres. Colloids and Surfaces A: Physicochemical and Engineering Aspects, 2011. 89-99.

33. LINS, D.; ALÉCIO, E. Microscopia Ótica. CEFET PE. Pernambuco. 2007.

34. PARK, K. J.; ANTONIO, G. C. Análises de Materiais Biológicos - Notas de Aula. UniCamp. Campinas. 2006.

35. CASTRO, L. A. S. Processamento de Amostras para Microscopia Eletrônica de Varredura. Embrapa Clima Temperado. Documentos, Pelotas, 2001. 37p.

36. GHAVAMI, K. Application of bamboo as a low-cost construction material. Bamboo current research. In: International Bamboo Workshop. Cochin, 1988. Singapura: Kerala Forest Research Institute and IDR, 1990. p. 270-279.

37. CULZONI, R. A. M. Características dos bambus e sua utilização como material alternativo no concreto. PUC-Rio. Rio de Janeiro, p. 134. 1986.

38. BERALDO, A. L.; AZZINI, A.; GHAVAMI, K.; PEREIRA, A. R. Tecnologias e materiais alternativos de construção. In: FREIRE, W. J. Bambu: características e aplicações. Campinas: Unicamp, 2003. 
39. GHAVAMI, K.; HOMBECK, R. V. Application of bamboo as a construction material: Part I - Mechanical properties and water repellent treatment of bamboo. Proceedings of the Latin American Symposium on Rational Organization of Building Applied Low cost Housing, São Paulo, 1981. 49-66.

40. GHAVAMI, K.; SOUZA, M. V. Propriedades Mecânicas do Bambu. RMNC1 Bambu, Rio de Janeiro, 2001.

41. JANSSEN, J. J. A. The mechanical properties of bamboo used in construction. Bamboo research in Asia: Proceedings of workshop held in Singapura, Ottawa, 1980. 173-188.

42. GROSSER, D.; LIESE, W. On the Anatomy of Asian Bamboo's, with Special Reference to their Vascular Bundles. Wood Science and Technology, 1974. 290-312.

43. LEE, A. W. C.; BAI, X.; PERALTA, P. N. Selected physical and mechanical properties of giant timber bamboo grown in South Carolina. Forest Products Journal, 44, 1994. 40-46.

44. AMERICAN SOCIETY FOR TESTING AND MATERIALS. ASTM D-1037: Standard Test Methods for Evaluating Properties of Wood-Base Fiber and Particle Panel Materials. [S.I.]. 2006.

45. AHMAD, M. Analysis of Calcutta Bamboo for Structural Composite Materials. Virginia Polytechnic Institute and State University. Virginia. 2000.

46. YU, H. Q.; JIANG, Z. H.; HSE, C. Y.; SHUPE, T. F. Selected physical and mechanical prpperties of Moso Bamboo (Phyllostachys pubescens). Journal of Tropical Forest Science, 4, 2008. 258-263.

47. MURAD, J. R. L. As propriedades físicas, mecânicas e meso-estrutural do bambu Guadua weberbaueri do Acre. PUC-Rio. [S.I.]. 2007.

48. LEE, A. W. C.; XUESONG, B.; PERRY, N. P. Selected physical and mechanical properties of giant timber bamboo grown in South Carolina. Forest Prod.J., 9, 1994. 40-46.

49. GHAVAMI, K.; MARINHO, A. B. Propriedades físicas e mecânicas do colmo inteiro do bambu da espécie Guadua angustifolia. Revista Brasileira de Engenharia Agrícola e Ambiental, 9, 2005. 107-114.

50. GHAVAMI, K.; TOLEDO FILHO, R. D. Desenvolvimento de materiais de construção de baixo consumo de energia usando fibras naturais, terra e bambu. Revista Engenharia Agrícola. Publicação Sociedade Brasileira de Engenharia Agrícola, 2, 1992. 1-19.

51. PEREIRA, M. A. R. Projeto bambu: manejo e produção do bambu gigante (Dendrocalamus giganteus) cultivado na Unesp de Bauru / SP e 
determinação de características mecânicas de ripas laminadas. Seminário Nacional de Bambu: estruturação da rede de pesquisa e desenvolvimento, Brasília, 2006b. 91-103.

52. GHAVAMI, K.; MARINHO, A. B. Determinação das propriedades dos bambus das espécies: Mosó, Matake, Guadua angustifolia, Guadua tagoara e Dendrocalamus giganteus para utilização na engenharia. Publicação RMNC Bambu, Rio de Janeiro, 2001. 53.

53. GHAVAMI, K.; MARINHO, A. B. Propriedades Mecânicas dos Colmos dos Bambus das Espécies: Mosó e Guadua angustifolia para Utilização na Engenharia. Publicação RMNC-2 Bambu 02/2002, Rio de Janeiro, 2002. 90.

54. CORREAL, J. F.; ARBELÁEZ, J. Influence os Age and Heigh position on colombian Guadua angustifolia bamboo mechanical properties. Maderas ciencia y tecnologia, n. 12, 2010. 105-113.

55. PEREIRA, M. A. R. Projeto bambu: manejo e produção do bambu gigante (Dendrocalamus giganteus) cultivado na Unesp / Campus de Bauru e determinação de suas características físicas e de resistência mecânica. Unesp. [S.I.]. 2006a.

56. NOGATA, F.; TAKAHASHI, H. Intelligent Functionally Graded Material: Bamboo. Composites Engineering, 5, 1995.

57. THOULESS, M. D. Stress evolution during electromigration in a bamboo structure. Scripta Materialia, 34, 1996.

58. LAKKAD, S. C.; PATEL, J. M. Mechanical properties of bamboo, a natural composite. Fiber Sci.Technology, 1980. 319-322.

59. AMADA, S.; ISHIKAWA, Y.; MUNEKATA, T.; NAGASE, Y.; SHIMIZU, H. Fiber texture and mechanical graded structure of bamboo. Composites, 1997. 13-20.

60. VERMA, C. S.; CHARIAR, V. M. Stiffness and strength analysis of four layered laminate bamboo composite at macroscopic scale. Composites: Part B, 2013. 369-376.

61. JAIN, S.; KUMAR, R. Mechanical behavior of bamboo and bamboo composites. Journal of materials science, 27, 1992. 4598-4604.

62. OKUBO, K.; TORU, F.; YUZO, Y. Development of bamboo based polymer composites and their mechanical properties. Composites: Part A: Applied Science and Manufacturing, 35, 2004. 377-383.

63. THWE, M. M.; LIAO, K. Durability of bamboo-glass fiber reinforced polymer matrix hybrid composites. Composites science and technology, 63, 2003. 375-387. 
64. KINOSHITA, H.; KOICHIKAIZU; MIKIFAKUDA. Development of green composites consists of wood chips, bamboo fibers and biodegradable adhesive. Composite part B: engineering, 40(7), 2009. 607-612.

65. SHIBATA, S.; YONGCA; FUKUMOTO, I. Flexural modulus of unidirectional and random composites made from biodegradable resin and bamboo and kanaf fibers. Composites part $A, 2008$. 9-15.

66. JINDAL, U. C. Development and testing of bamboo-fibers reinforced plastic composites. Journal of Composite Materials, 20, 1986. 19-29.

67. RAJULU, A. V.; BAKSH, S. A.; REDDY, G. R.; CHARY, K. N. Chemical resistance and tensile properties of short bamboo fiber reinforced epoxy composites. Journal of Reinforced Plastics and Composites, 17, 1998. 1507-1511.

68. CHEN, X.; GEO, Q.; MI, Y. Bamboo fiber-reinforced polypropylene composites: a study of mechanical properties. Journal of Applied Polymer Science, 69(10), 1999. 1891-1899.

69. AMADA, S.; UNTAO, S. Fracture properties of bamboo. Composites part B: Engineering, 32, 2000. 451-459.

70. SHIN, F. G.; XIAN, X. J.; YIPP, M. W. Analysis of the mechanical properties and micro-structure of bamboo-epoxy composites. Journal of material science., 24, 1989. 3489-3490.

71. VERMA, C. S.; CHARIAR, V. M.; PUROHIT, R. Tensile Strength Analysis of bamboo and Layered Laminate Bamboo composites. International Journal of Engineering Research and Applications (IJERA), 2, n. 2, 2012. 1253-1264

72. VERMA, C. S.; CHARIAR, V. M. Development of layered laminate bamboo composite and their mechanical properties. Composites: Part B, 43, 2012. 1063-1069.

73. CARRASCO, E. V. M.; E.V.; MOREIRA, L.E.; XAVIER, P.V. Bambu Laminado e Colado. Anais $V$ Encontro Brasileiro em Madeiras e em Estruturas de Madeira. Ebramem., Belo Horizonte, 2, 1995. 411-423.

74. LAPO, L. E. R.; BERALDO, A. L. Bambu Laminado Colado "BLC". Revista em agronegócios e meio ambiente - RAMA, Maringá, 1, 2008.

75. GONÇALVES, M. T. T.; PEREIRA, M. A. R.; GARBINO, L. V. Métodos de ensaio de bambu laminado. Anais Encontro Brasileiro em Madeiras e em Estruturas de Madeira, Uberlândia, 2002.

76. GARBINO, L. V.; GONÇALVES, M. T. T.; PEREIRA, M. A. D. R. Métodos de ensaio para amostras de bambu laminado. Uberlândia. 2002. 
10.

77. BERALDO, A. L.; RIVERO, L. A. Bambu Laminado Colado (BLC). Floresta e Ambiente, 10, 2003. 36-46.

78. AMERICAN SOCIETY FOR TESTING AND MATERIALS. ASTM D5456. Standard Specification for Evaluation of Structural Composite Lumber Products. [S.I.]. 2014.

79. AMERICAN SOCIETY FOR TESTING AND MATERIALS. ASTM D-198. Standard Test Methods of Static Tests of Lumber in Structural Sizes. [S.I.]. 2014.

80. IMPERVEG. Imperveg Poliuretano Vegetal. imperveg.com.br. Disponivel em: <http://imperveg.com.br/familia-de-resinas/>. Acesso em: 2014.

81.ZEISS. Industrial Metrology. Zeiss.com. Disponivel em: $<$ http://www.zeiss.com/industrial-

metrology/en_us/products/systems/computedtomography/jcr_content/mainpar/atiteaser_92da/image.img.jpg/1401722018 488.jpg/metrotom_1500_machine.jpg >. Acesso em: 13 october 2015.

82. PACIORNIK, S. Laboratório de Processamento Digital de Imagens. Ipdipuc.jimdo.com, 2015.2 Disponivel em: <http://pdipuc.jimdo.com/portugu\%C3\%AAs/microtomografia/zeiss-xradiaversa-510/>. Acesso em: 5 agosto 2015.

83. GIBSON, L. J.; ASHBY, M. F.; HARLEY, B. Cellular Materials in Nature and Medicine. New York: Cambridge University Press, 2010. ISBN 978-0-52119544-7.

84. RAY, A.K.; MONDAL, S.; DAS, S.K.; RAMACHANDRARAO, P. Bamboo - A functionally graded composite correlation between microstructure and mechanical strenght. Journal of Materials Science, 2005.

85. AMERICAN SOCIETY FOR TESTING AND MATERIALS. ASTM D-3039. Standard Test Method for Tensile Properties of Polymer Matrix Composite Materials. [S.I.]. 2008.

86. KRAUSE, J. Q. Desenvolvimento de elementos espaciais de bambu para treliças espaciais. PUC-Rio. Rio de Janeiro. 2009.

87. AMERICAN SOCIETY FOR TESTING AND MATERIALS. ASTM D-3410. Standard Test Method for Compressive Properties Compressive Properties of Polymer Matrix Composite Materials with Unsupported Gage Section by Shear Loading. [S.I.]. 2008.

88. INC., WYOMING TEST FIXTURES. Wyoming Test Fixtures. www.wyomingtestfixtures.com. Disponivel em: 
10.

<http://www.wyomingtestfixtures.com/Products/b3_files/image001.jpg>.

Acesso em: 14 setembro 2015.

89. COMPOSITES WORLD. Composites World. www.compositesworld.com. Disponivel em: <http://www.compositesworld.com/articles/currentcompression-test-methods>. Acesso em: 14 setembro 2015.

90. GHAVAMI, K.; MARINHO, A. B. Popriedades mecânicas dos colmos dos bambus das espécies: Mosó e Guadua angustifolia para utilização na Engenharia. PUC-Rio. Rio de Janeiro. 2000.

91. AMERICAN SOCIETY FOR TESTING AND MATERIALS. ASTM D-3163. Standard Test Method for Determining Strength of Adhesively Bonded Rigid Plastic Lap-Shear Joints in Shear by Tension Loading. [S.I.]. 2001.

92. WILCOX, W. W. Preparation of decayed wood for microscopical examination. Forest Products' Laboratory, Forest Service U.S. Department of Agriculture. Madison. 2001.

93. TIMM, L. L. Técnicas rotineiras de preparação e análise de lâminas histológicas. Caderno La Salle XI, Canoas, v.2, 2005. 231 - 239.

94. SILVEIRA, M. Preparação de amostras biológicas para microscopia eletrônica de varredura. In: Manual sobre técnicas básicas em microscopia eletrônica. São Paulo: USP, v. 1, 1989. p. 71-79. 